Geology of the

Souris River Area

North Dakota

GEOLOGIGAL SURVEY PROFESSIONAL PAPER 325

Prepared as a part of a program of the Department of the Interior for development of the Missouri River basin

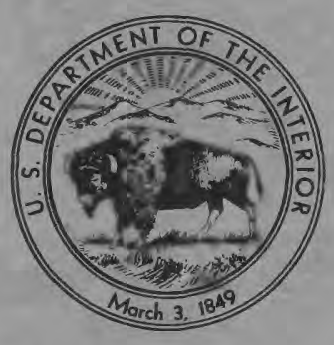




\section{Geology of the}

Souris River Area

North Dakota

By RICHARD W. LEMKE

GEOLOGICAL SURVEY PROFESIONAL PAPER 325

Prepared as a part of a program of the

Department of the Interior for development of the Missouri River basin

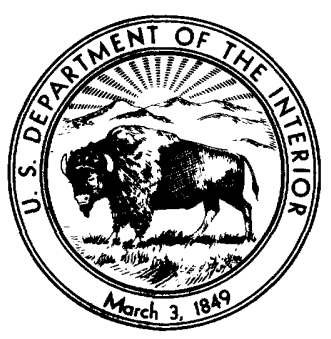

UNITED STATES GOVERNMENT PRINTING OFFICE, WASHINGTON : 1960 


\section{UNITED STATES DEPARTMENT OF THE INTERIOR}

FRED A. SEATON, Secretary

GEOLOGICAL SURVEY

Thomas B. Nolan, Director 


\section{CONTENTS}

Abstract

Introduction .

Methods of study

Acknowledgments

Geography

Location and extent of area

Climate.

Culture

Population

Transportation $\ldots \ldots \ldots$

Industry $\ldots \ldots \ldots$

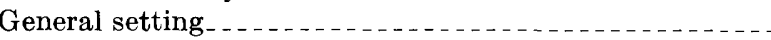

Physiographic provinces

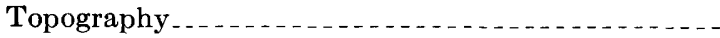

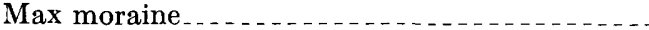

Ground-moraine plain ...................

Glacial Lake Souris area

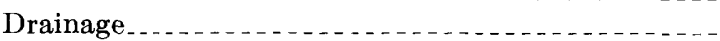

Previous published work

Descriptive geology

Rocks of pre-Late Cretaceous age

J. H Kline 1 well.

Des Lacs Western, Blum 1 well

Other wells..............................

Summary: rocks of pre-Late Cretaceous age

Upper Cretaceous rocks.............

Pierre shale (not exposed)

Fox Hills sandstone. . . . . . . .

Hell Creek formation

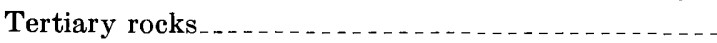

Cannonball member of the Fort Union forma-

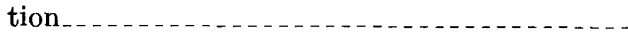

Tongue River member of the Fort Union forma-

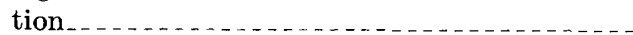

Pleistocene deposits

Glacial drifts in North Dakota............

Possible criteria for differentiation of Wisconsin substages

Pleistocene deposits in Souris River area

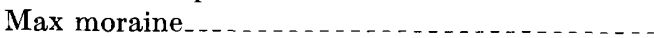

Ground moraine................

Overridden ice-contact deposits.............

Linear-ridge deposits . . . . . . . . . . . . . . . . . .

Diversion-channel deposits . . . . . . . . . . . . .

River-terrace deposits......................

Kames and eskers.

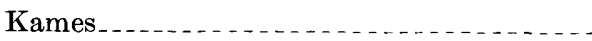

Eskers..............

End moraines in Souris loop area...........

Ice-marginal outwash-channel deposits.......

Glaciofluvial deposits, undifferentiated as to origin

Deposits of glacial Lake
Page
Descriptive geology-Continued Page

Recent deposits._._.

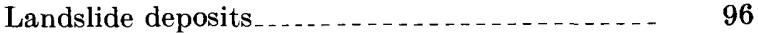

Dune sand $\ldots \ldots \ldots 9$

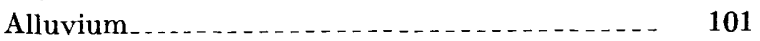

Structure of Upper Cretaceous and Tertiary rocks__._._. 104

Direct evidence of structure in Souris River area_._- 104

Structure shown by lignite bed in southeastern

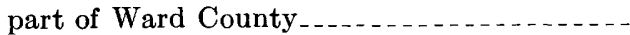

Dip of Fort Union formation sandstone bed

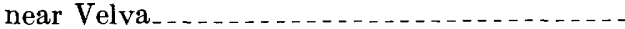

Direct evidence of structure in adjacent areas .......

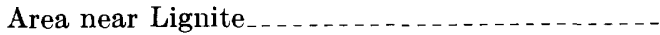

Nesson anticline $\ldots \ldots \ldots$

Structure in Knife River area..............

Fault block and other structure in southern

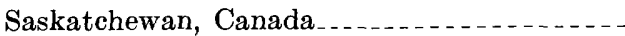

Dip of lignite bed southeast of mapped area.....

Deformation of Colgate member of Fox Hills(?) sandstone southeast of Souris River area.....

Problematical and indirect inference of structure within and adjacent to the mapped area............ Steep dip of lignite bed west of mapped area..... Inferred structure in Kidder County.

Structure inferred from the location of springs

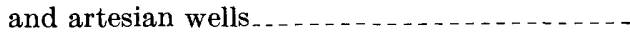

Disturbed Fort Union strata on west flank of

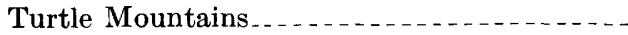

Possible significance of bedrock high under the Max moraine........................................

Erosional features that may be structurally controlled. . . . . .

Possible structure of the Bottineau County gas field

Possible structure based on topographic position

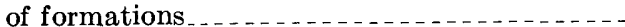

Summary of evidence of structure in Souris River

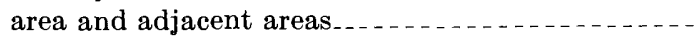
Pre-Pleistocene and Pleistocene drainage Summary history of Pleistocene deposits...............

Setting prior to glaciation

Setting during glaciation.............................

Synthesis of glacial history in Souris River area and vicinity $\ldots \ldots \ldots$

Glaciation during Mankato substage in Souris River area Max moraine........................ 113 Area northeast of Max moraine........ 113

History of recent deposits ........................ 117

Economic geology $\ldots \ldots \ldots \ldots 117$

Lignite

Burke County

Mountrail County $\ldots \ldots \ldots \ldots$

Ward County 
Economic geology-Continued

Lignite-Continued

Renville County

Bottineau County.

McHenry County

McLean County

Sheridan County

Petroleum

Gas_.

Construction materials

Sand and gravel.

Riprap and building stone
Economic geology - Continued

Construction materials-Continued Page

Till

Sodium sulfate $\ldots \ldots \ldots$

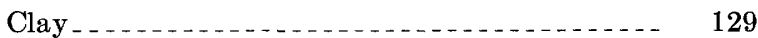

Relation of geology to agricultural development _._. 129

Relation of geology to construction problems. . . . . 130

Highway construction ... . . . . . . . . . . . 130

Construction relating to irrigation ........... 131

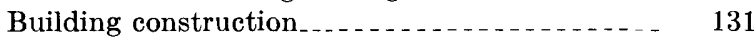

References cited...

Index

\section{ILLUSTRATIONS}

[Plates 1, 2, 14, 15, and 16 are in pocket]

Plate 1. Geologic map of the Souris River area (two parts).

2. Contour map of the bedrock surface, Souris River area.

Facing page

3. Exposure of the Colgate member of Fox Hills sandstone east of Anamoose, showing miniature badland topography

4. High-altitude photograph of area southwest of Kenmare in Burke County

5. A. View of the Max moraine near western edge of mapped area.

$B$. View of road cut south of Minot, N. Dak., showing deformed lenses of silt beds in till

6. A. Exposure in Ward County, showing sand beds off set by many small faults.

$B$. Ice-contact deposit of poorly sorted gravel overlain by till, in gravel pit on northern outskirts of Minot...--

7. High-altitude photograph of area southeast of Velva showing low arciate ridges and chains of intervening undrained depressions between the Velva and Lake Hester diversion channels . . . . . . . . . . . . . . . Backing 59

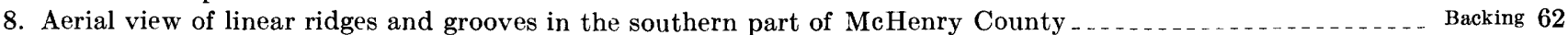

9. A. View of a terrace deposit near Greene, Renville County, showing well-rounded coarse gravel in a pit in the valley of the Souris River.

$B$. View of a terrace deposit in Ward County, showing boulder-studded surface

10. A. View of a typical kame.

$B$. View of material in a kame.

11. View of two landslide areas along valley walls of tributaries of the Des Lacs River

12. View of the slide area along valley wall of the Souris River near the south end of Lake Darling _... Backing 96

13. View of northwest-trending dune groups southwest of Denbigh.

14. Map showing pre-Mankato drainage courses in the Souris River area and adjacent parts of North Dakota.

15. Generalized physiographic map of glacial Lake Souris area and vicinity.

16. Map showing location and names of lignite mines in vicinity of Kenmare.

Figure 1. Index maps showing general location of the Souris River area, area of geologic mapping, and physiographic subdivisions

2. Bedrock geology of northwestern and north-central North Dakota

3. Correlations of five wells in the Souris River area

4. Stratigraphic section of Upper Cretaceous and Tertiary formations between Glendive, Mont., and Verendrye, N. Dak ..............

5. Diagrammatic cross section of bedrock underlying the Max moraine

6. Map showing drift borders in North Dakota

7. Rose diagrams showing orientation of pebbles in till

8. Section along highway cut in Ward County, 11/2 miles southeast of Donnybrook, showing two tills separated by a boulder belt.

9. Cross section in gravel pit $1 \frac{11}{2}$ miles southeast of Donnybrook

10. Cross section of linear ridge in the southern part of McHenry County

11. Generalized cross section of the crest of a till-rich esker in Mountrail County

12. Size analyses of glacial-lake sand and dune sand

13. Diagrammatic cross section of a typical landslide in the Des Lacs River area

14. Generalized cross section showing tilted and distorted beds

15. Generalized cross section showing distorted beds

16. Cross section of the valley of the Des Lacs River, $1 \frac{1 / 2}{2}$ miles northwest of Kenmare

17. Map showing location of wells drilled for oil in the Souris River area and vicinity before 1953 .

Page 


\title{
GEOLOGY OF THE SOURIS RIVER AREA, NORTH DAKOTA
}

\author{
By Richard W. LEMke
}

\begin{abstract}
The Souris River area comprises about 5,500 square miles in north-central North Dakota. It is bounded roughly by the east loop of the Souris River on the east, by the Max moraine on the southwest, and by the International Boundary on the north. Much of the total area is a ground-moraine plain. The Souris River and its tributary, the Des Lacs River, are the main streams. Most of the area, however, is without integrated drainage. The highest point is on the Max moraine at an altitude of about 2,500 feet. The lowest point is in the Souris River valley at the International Boundary at an altitude of 1,410 feet. The northeast-facing escarpment of the Max moraine forms the boundary between the Great Plains physiographic province and the Central Lowlands province. The part of the Great Plains province that is within the mapped area includes the Max moraine and is known as the Coteau du Missouri.
\end{abstract}

A large part of the proposed Missouri-Souris irrigation project in North Dakota is within the mapped area. Extensive exploration for oil within and adjacent to the area has resulted from discovery of large oil reserves elsewhere in the Williston basin. Farming, however, remains the chief industry. Minot, with a population of 22,032 in 1950 , is the largest city.

Most of the area is mantled with surficial deposits, chiefly of Pleistocene age. Rocks of Late Cretaceous and Tertiary age underlie the surficial deposits and crop out locally. Data on subsurface formations are based on logs of several wells drilled for oil. One well in the northeast part of the area penetrated Precambrian rocks at a depth of 8,262 feet. In addition to Tertiary and Cretaceous sediments, Jurassic, Triassic, Mississippian, Devonian, Silurian, and Ordovician rocks have been recognized in the drill holes.

The Pierre shale, Fox Hills sandstone, and possibly the Hell Creek formation of Late Cretaceous age directly underlie surficial deposits along the east and northeast margins of the mapped area. Elsewhere, Tertiary rocks underlie the surficial deposits. The Pierre shale is nowhere exposed in the area, but well data and exposures nearby show that it consists largely of grayish blue, poorly indurated shale, which has pronounced rectangular partings. Several species of Foraminifera from the formation have been identified. There is only one exposure of possible Fox Hills sandstone. It consists chiefly of poorly consolidated medium-grained orange-yellow sandstone that contains concretions. Although the Hell Creek formation underlies Tertiary rocks in the western part of the area, it is believed to be nowhere exposed and may not persist far enough east to come in direct contact with the surficial deposits.

The Tertiary rocks consist of the Cannonball and Tongue River members of the Fort Union formation of Paleocene age. The marine Cannonball member is the uppermost bedrock unit in most of the eastern and southeastern parts of the area; a few exposures along the Souris River valley and to the southeast indicate a maximum thickness of about 40 feet. The member consists chiefly of thinly bedded fossiliferous brown sand and sandy shale. It contains numerous species of Foraminifera, some newly described. The continental Tongue River member overlies the Cannonball member and is the uppermost bedrock unit of most of the area. Under the Max moraine, it may have a thickness greater than 900 feet. The Tongue River member consists of poorly consolidated sandstone, sand, siltstone, shaly clay, and lignite. A few vertebrate and invertebrate fossils have been found. The lignite beds, some of which are 10-15 feet thick, are the chief aquifers of the area. Other beds range widely in permeability. Slope stability also varies markedly.

The Pleistocene deposits are Wisconsin in age, and, except for a few deposits along the valley of the Des Lacs River, all are believed to be of the Mankato substage of glaciation. The deposits have been mapped as the following geologic units: Max moraine, ground moraine, overridden ice-contact deposits, linear-ridge deposits, diversion-channel deposits, river-terrace deposits, kames and eskers, end moraines in the Souris loop area, ice-marginal outwash-channel deposits, glaciofluvial deposits undifferentiated, and deposits of glacial Lake Souris.

The Max moraine covers the southwest part of the area. Its surface is characterized by innumerable knobs, ridges, and kettles and other undrained depressions. The moraine consists mostly of stony clay till, generally 100-200 feet thick; locally, where it fills preglacial valleys, it may be much thicker. The Max moraine forms the surface of the Coteau du Missouri and owes much of its prominence to a buried bedrock platform. When dry, the till of the Max moraine stands in nearly vertical slopes, but when wet, it tends to slump; it is nearly impermeable.

Ground moraine is the most widespread map unit. It forms a relatively fiat plain which slopes gently northeastward from the Max moraine to the area covered by deposits of glacial Lake Souris. In most places, its thickness is 50-200 feet. It consists essentially of stony clayey till. Pebbles and larger size stones are mostly carbonate rocks, followed by granitic and gneissic rocks. The till of the ground moraine, like that of the Max moraine, is very stable when dry and is nearly impermeable.

The overridden ice-contact deposits are exposed locally along the Souris River from Minot downstream for several miles. They are both overlain and underlain by till and consist mostly of fine sand to coarse gravel a few inches to about 30 feet thick. In the large-size fraction, carbonate rocks predominate; granitic and gneissic rocks are next most abundant. Many of the beds are characterized by small, moderate- to high-angle faults, which suggests collapse and slump. 
In the southeast part of the area, many straight parallel ridges trend southeast. These ridges are interpreted to be a special type of drumlinoidal feature, but, because definite proof is lacking as to their origin, they have been nrapped as "linearridge deposits." Shallow parallel grooves in the intervening ground moraine and arcuate transverse ridges of till, interpreted to be recessional moraines are associated with the ridges. The linear ridges are generally $1-3$ miles long, 5-15 feet high, and have even crestlines. The largest ridge, however, is $13 \frac{1}{2}$ miles long and 15-30 feet high. Larger ridges consist mostly of stratified sand and incorporated bodies of till. Ridges less than 5 feet high consist almost entirely of till.

Glacial melt water that was diverted from the Souris River valley by ice has cut several large diversion channels. The main diversions were about 25 miles downstream from Minot, where shallow channels, mostly $1 / 2-2$ miles wide, were cut in ground moraine. Laid down in these channels were deposits of gravel, sand, and silt, generally 5-15 feet thick.

Terrace remnants, possibly kame terraces, are fairly numerous along the valley walls of the Souris and Des Lacs Rivers. Most are less than half a mile long and a few hundred feet wide. The terrace deposits range in thickness from a few inches to more than 50 feet; they range in composition from silt to boulders, but sand and gravel predominate. Carbonate rocks are most abundant; granite and gneissic rocks are next most abundant. Sorting is poor to moderate. Permeability and porosity are high. Most of the coarser fraction is satisfactory for construction purposes.

The abundant kames and eskers are characterized by variations in size, shape, lithology, and structure. They have the common features of (a) consisting predominately of poorly sorted gravel, sand, and silt, and of minor anounts of till, (b) possessing collapsed bedding, and (c) having specific dimensions and landforms different from other glaciofluvial deposits.

Five hummocky areas surrounded by ground moraine have been mapped as end moraines in the Souris loop area. They are not typical of other end moraines in the region because they contain large amounts of stratified ice-contact deposits incorporated in the otherwise stony clay till.

During melting of the last glacier ice covering the region. glacial melt water cut a conspicuous and unusual pattern of long outwash channels in the ground moraine. These channels are believed to have formed mostly along successive positions marginal to the southwest side of the last ice lobe to cover the area. Outwash that consists of gravel, sand, silt, and clay underlies the bottom and, in a few places, the walls of the channels. This ranges in thickness from a thin skin to 20 feet or more. Permeability of the sand and gravel is high, and special problems of leakage will probably arise if canals or dams are built in this material.

Many stratified glacial deposits, of uncertain origin, are scattered throughout the mapped area; they are described under the heading "Glaciofluvial deposits, undifferentiated as to origin."

Deposits of glacial Lake Souris cover most of the eastern part of the area. Their surface is conspicuously fiat. The deposits range from a known thickness of 73 feet to a featheredge. They consist mostly of sand and silt and in most places are underlain by till.

Recent deposits are landslides, dune sand, and alluvium. However, all three probably began to form while the last ice sheet was melting from the area and hence are partly contemporaneous with some of the latest Pleistocene deposits.
Large and impressive landslides are abundant along the valley walls and tributaries of the Des Lacs River and along the valley walls of the upper reaches of the Souris River. In the Des Lacs River area, long parallel blocks of Fort Union strata, overlain by a thick section of till, have broken away from steep valley-wall slopes and have rotated, producing a series of successively lower ridges parallel to the valley wall. Little material is sliding at present. In the Souris River valley area, only till and stratified glacial deposits appear to have slid. The type of slide in the Souris River valley forms crescent-shaped areas of low, arcuate, parallel ridges and undrained depressions on the upslope side. There is no evidence of recent sliding and most of the material probably moved soon after the glacial ice melted from the valley.

Dune sand is confined mostly to the glacial Lake Souris area. The dunes consist of parallel to subparallel ridges, as much as 50 feet high, whose long axes generally trend northwest. Dune groups formed by several closely spaced individual dunes also trend northwest. Most dunes are partly stabilized by shrubs and small trees but some are active. Permeability is high.

Alluvium consists of clay, silt, sand, and fine gravel deposited chiefiy along the valley floors of the Souris and Des Lacs Rivers, and their main tributaries. It is probably less than 30 feet thick under the valley floors of the two main valleys and is underlain by glacial outwash of similar composition. Permeability is generally less than in other stratified surficial deposits and subsurface drainage is generally poor. Slope stability generally is low to moderate.

Most of the area is believed to lie within a broad, shallow syncline that trends northwest into Canada. A zone of folds and faults may extend many miles parallel to the escarpment of the Coteau du Missouri along a bedrock bench just west of the mapped area. The escarpment itself may be a fault scarp. If so, the Coteau du Missouri may be high structurally as well as topographically.

The preglacial drainage pattern differed from the present pattern. The ancestrial Knife River crossed the Coteau du Missouri and may have flowed northward through the eastern part of the mapped area. Parts of the valleys of the Souris and Des Laes River probably were cut in Pleistocene time, prior to the last glaciation.

North Dakota was glaciated at least three times. Tills of the Iowan, Tazewell, and Mankato substages of the Wisconsin stage have been recognized south of the mapped area. However, except for a few exposures along the valley of the Des Lacs River that might be of Tazewell or Iowan substage, only deposits of Mankato substage have been recognized in the Souris River area. During the later part of the Mankato substage, a long, narrow lobe of ice advanced southeastward across the area between the escarpment of the Coteau du Missouri and the Turtle Mountains. This lobe, here named the Souris River lobe, extended a short distance southeast of the mapped area. At approximately the same time that the Souris River lobe covered much of the Souris River area, a second lobe of ice advanced around the east flank of the Turtle Mountains and covered the area east of the Souris River area. This lobe is named the Leeds lobe. During deglaciation, the sides and the terminus of the Souris River lobe melted simultaneously, and southeast-trending ice-marginal channels formed along the southwest side of the lobe. The southern part of glacial Lake Souris came into existence as the Souris River lobe melted back from low ground southeast of the mapped area ; further melting expanded the lake to the northwest. The lake flrst overflowed southeastward through spillways; finally, when the 
Souris River valley became free of ice, the lake drained northward into Canada.

Mineral resources include lignite, petroleum, gas, construction materials, sodium sulfate (Glauber salt), and clay. The last two have little or no present economic signifleance.

North Dakota produced about 3,260,973 tons of lignite in 1950, of which 577,515 came from the Souris River area. The Souris River area lies mostly in the eastern part of the North Dakota lignite flelds, although its eastern boundary is beyond the lignite-bearing strata. Natural exposures of lignite are scarce and present-day mining is confined almost exclusively to a few strip mines south of Velva. Reserves in the Souris River area are estimated at 9,762.5 million short tons.

Oil was flrst discovered in the State in 1951 , about 75 miles west of Minot. By 1952, twelve dry holes had been drilled in the Souris River area. In 1953 oil reportedly was found in the northeast part of the area.

Some kinds of construction materials are abundant in the Souris River area but others are scarce. Sand and gravel are plentiful and nearly all the deposits are suitable for road metal. Most deposits can also be used for concrete aggregate and other purposes. On the other hand, quarry rock suitable for building purposes is almost totally lacking.

Surface geology and agricultural development are directly related. Some characteristics of the geologic units favor agricultural development; others are detrimental. Poor surface drainage and low permeability of the ground moraine severely limit irrigability of much of the area. On the other hand, the ground moraine is well suited for dry farming. Poor surface drainage prevents rapid runoff and the nearly impermeable till holds moisture in the upper part of the soil proflle. The till decomposes rather quickly into a fertile soil.

A direct relation also exists between geology and construction. At present, the major construction is road building. Sand and gravel are plentiful for bituminous mix, as well as for road metal. Till is the most common subgrade material, forming a stable roadbed. It compacts well, is little susceptible to frost heaving, and is fairly stable in road cuts. Roads built across stratifled glacial deposits are generally stable. Several types of problems, however, develop in building roads across deposits of glacial Lake Souris. Roads built in sand are subject to wind erosion of grade, fllling of ditches, gullying, and lateral displacement of grade, owing to low cohesion of the sand grains. Roads built in silt deposits are susceptible to frost heaving. Drainage is a problem in building roads across valley alluvium. Lignite beds should be avoided in constructing roads because they are poor fll material and are the chief aquifers. Landslides should be avoided because of the danger of reactivating the slides. Leakage is probable in canals constructed in some outwash deposits.

\section{INTRODUCTION}

\section{GENERAL LOCATION AND PURPOSE OF WORK}

The Souris River area comprises about 5,500 square miles in north-central North Dakota (fig. 1).

The purpose of the investigations was to supply basic geologic data to Federal agencies engaged in the Missouri River Development Program and to add to the

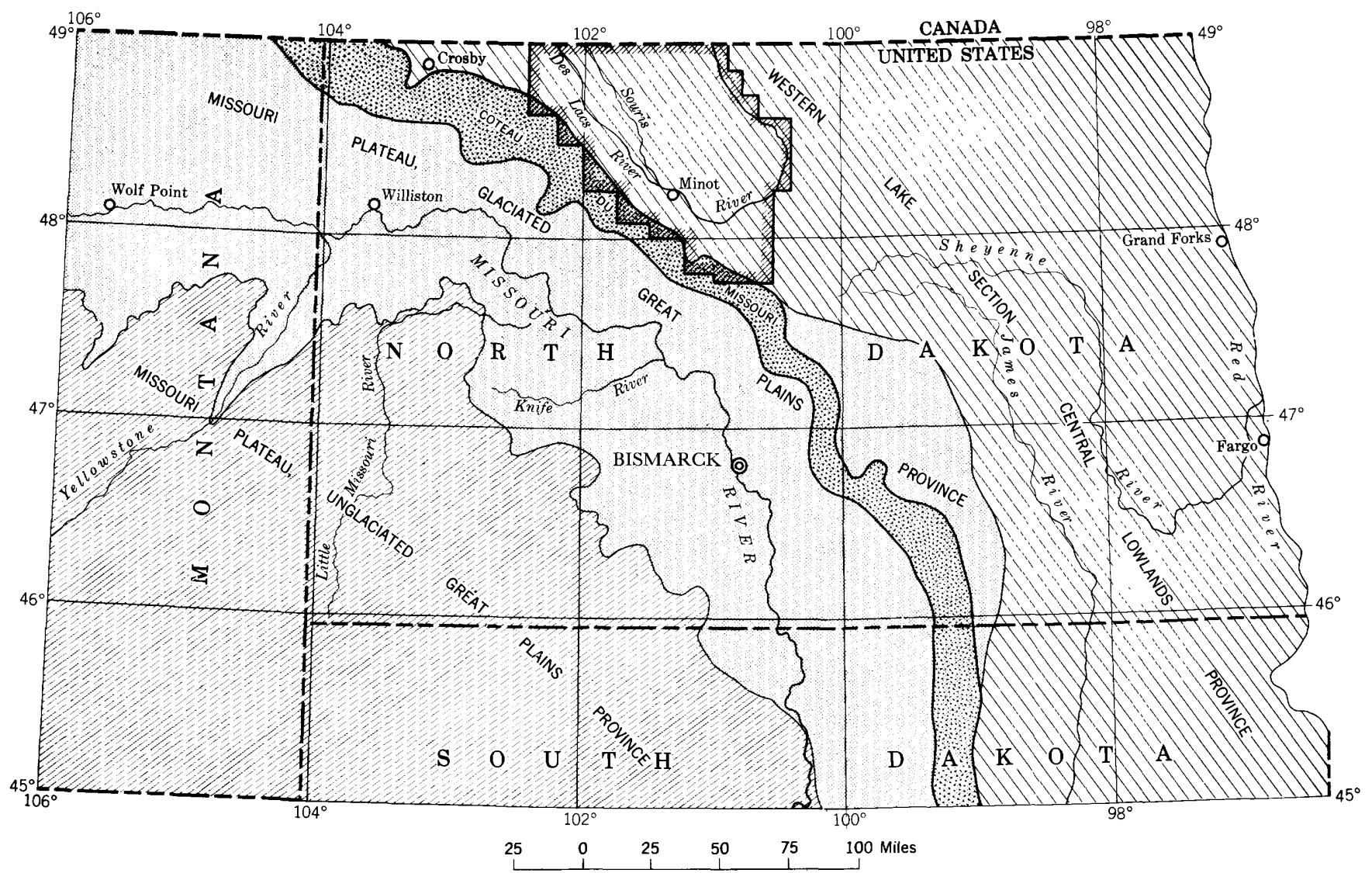

Frgure 1.-Index maps showing general location of the Souris River area, araa of geologic mapping, and physiographic subdivisions. 
GEOLOGY OF THE SOURIS RIVER AREA, NORTH DAKOTA

geologic knowledge of an area where only scanty geologic work had been done previously. A large part of the proposed Missouri-Souris irrigation project in North Dakota is included in the mapped area. The full extent of the proposed project is shown in U. S. Senate Document 191, 1944.

\section{METHODS OF STUDY}

The geology was mapped on aerial photographs, mostly on a scale of $1: 20,000$, and outlines were then transferred by sketchmaster to base maps at a scale of $1: 31,680$, made from U. S. Geological Survey horizontal control data, from triangulation stations of the U. S. Coast and Geodetic Survey, and from township plats of the Bureau of Land Management. Nearly all section corners were accurately located on the photographs, facilitated by roads that bound nearly every section. Culture was interpreted from the photographs and in most places was field checked. Topographic maps for the Minot, Sawyer, Benedict, Kongsberg, and Balfour 15-minute quadrangles were available at the time of mapping. However, topographic bases for the remainder of the area were not completed until geologic mapping was finished or nearly finished. Where topography was not available, altitudes were determined by altimeter and by telescopic alidade. The lack of complete topographic coverage at the time of mapping was a definite handicap, especially in mapping the indistinct shoreline of glacial Lake Souris where relief is very slight.

Because of the flat terrain and a lack of adequate exposures in much of the area, hundreds of auger holes and shallow trenches, mostly less than 5 feet deep, were hand dug to obtain additional data. Information on deposits at greater depth was obtained chiefly from test holes drilled to depths as great as 300 feet, contracted for by the Water Resources Division of the U. S. Geological Survey. This information was supplemented by power augering directed by the writer. Depths to bedrock, thicknessess of coal beds, and other stratigraphic information were obtained from reported logs of water wells. Because most of this information was based on memories of varied reliability, information that appeared to be inaccurate was judiciously screened out. Data on bedrock formations at depth were obtained from several wells drilled for oil in the area. Information obtained from the J. H. Kline well 1 near Carpio was especially valuable. Holes drilled by the Bureau of Reclamation across the Des Lacs River north of Kenmare furnished data on depth of valley fill.
Topographic, lithologic, and age relations were used as criteria for differentiating surficial deposits.

\section{ACKNOWLEDGMENTS}

Mapping was started in midsummer of 1945 and completed in fall of 1949 . Chilton E. Prouty was in charge of the work in the vicinity of Minot during the first summer. Thereafter the writer was in general charge of mapping. The following other geologists participated actively in the mapping: Fred S. Jensen, J. Hiram Smith, Clifford A. Kaye, Lyman C. Huff, Page Truesdell, and Roy O. Jackson. Several of these men made special studies or mapped quadrangles independently or with little supervision from the writer, but their work was integrated into the general program and the results are included in this publication.

The writer wishes especially to express his appreciation to the above-named geologists. Without their industry, ideas, and active cooperation, both in the field and in the office, this publication would not have been possible. Particular credit is due Clifford A. Kaye (written communication) for his contribution to the section on landslides.

There was a constant interchange of information and ideas between R. C. Townsend, who mapped concurrently an adjacent area of four quadrangles to the west, and the writer. This information is so abundant and so much was obtained jointly that it will not be possible to acknowledge each contribution made by Townsend. Thanks are also especially due W. E. Benson, who furnished many helpful ideas and, with the writer, did reconnaissance work between the Souris River area and the Knife River area, which had been mapped by Benson, to the south. R. B. Colton furnished many valuable ideas, both in the field and in critical review of the manuscript. Through the efforts of Townsend, Benson, and Colton, a better knowledge of the regional glacial history was obtained than otherwise would have been possible. Grateful appreciation is also acknowledged to Roland W. Brown, for his finding and identification of diagnostic fossils during several field trips in the area, and to Steven K. Fox, who identified microfossils that confirmed the presence of the Cannonball member of the Fort Union formation in the area. The interpretations of W. A. Cobban, and C. L. Nieschmidt of the stratigraphy in the J. H. Kline well were of great value in the study of the rocks underlying the surface.

Other members of the U. S. Geological Survey working in the area, but not directly connected with the mapping program, were very helpful in providing stratigraphic logs and other data. Ground-water 
studies by George A. La Rocque, Jr., P. E. Dennis, P. D. Akin, and others were conducted concurrently with the geologic mapping.

Wilson M. Laird, State Geologist of North Dakota, was at all times most helpful in furnishing published and unpublished data. His excellent cooperation in integrating the State mapping program with that of the U. S. Geological Survey prevented duplication of work and promoted a beneficial exchange of geologic information. Close contact was maintained with $\mathrm{Bu}$ reau of Reclamation geologists, and geologic information was exchanged freely; Harold Kirchen and Herman Dupree were particularly helpful in supplying data on drill holes and materials. The Department of Agriculture furnished valuable data concerning the soils of the area.

The writer is indebted to the Dowey Price Drilling Company for allowing cuttings to be collected from the J. H. Kline well 1 . The operators of several lignite mines furnished maps and other data pertinent to the mines. Many residents of the area furnished information about their water wells.

\section{GEOGRAPHY}

\section{LOCATION AND EXTENT OF AREA}

The area comprises about 5,500 square miles in the north-central part of the State, mostly in the drainage basin of the Souris River. The Souris River flows from southeastern Saskatchewan, Canada, into North Dakota, where it turns northward and flows back through Canada into Lake Winnepeg. The part of North Dakota that is within the loop of the Souris River and an additional area extending several miles west and south of the river constitute broadly the area considered in this publication. All of Renville County is included, nearly all of Ward and McHenry Counties, and parts of Burke, Mountrail, McLean, Sheridan, and Bottineau Counties (see pl. 1, inset). The area includes 24 complete 15 -minute quadrangles and parts of 7 others, 'all between longitudes $100^{\circ} 221^{\prime} \mathbf{2}^{\prime}$ and $102^{\circ} 30^{\prime}$ and latitudes $47^{\circ} 45^{\prime}$ and $49^{\circ}$. The inset on plate 1 shows the quadrangles mapped and the major geologic and physiographic features. In addition to the above area several thousand square miles to the east and southeast were studied in reconnaissance and by photo interpretation. The results of part of these studies are shown in figure 8. Also, the bedrock was reconnoitered in most of the northwest one-fourth of the State (see fig. 2).

\section{CLIMATE}

The northern continental climate in the Souris River area is characterized by a wide temperature range
(U. S. Dept. Agriculture, 1941), rigorous winters, a summer rainy season, and strong northwesterly winds. The average January temperature is about $3^{\circ} \mathbf{F}$, and long periods of below freezing temperatures characterize the winters. Frost penetration averages 4 feet and reaches a maximum depth of about $61 / 2$ feet. July temperatures average $67^{\circ} \mathrm{F}$, and temperatures above $100^{\circ} \mathrm{F}$. are occasionally recorded in summer. Summer days are usually hot and clear, with low humidity in the afternoons. Owing to the northern location, there are more than 15 hours of sunshine per day from the middle of May to the end of July.

The average annual precipitation is 15 inches, twothirds of which falls in the period from May through September. In summer, heavy rainfalls of short duration are common. Because of the long warm sunny summer days, many crops can be grown in the relatively short growing season of about 117 days. Weather hazards to crops, however, are considerable, and hail, inopportune rains, and heat waves may cause failure. Droughts are common and in the past have been severe.

Prevailing winds from the northwest add to the rigors of the climate. Although the average annual wind velocity for the State is only about 10 miles an hour, blizzards in late winter and thunderstorms in spring are common. During dry periods severe dust storms cause extensive damage. Sudden hot winds of moderate velocity have parched large tracts of good crops ready for harvest.

\section{CULTURE}

\section{Population}

The low population density in the Souris River area is typical of the vast prairie country. Minot, the largest city in the area and third largest in the State, had a population of 22,032 people in 1950 . Kenmare had a population of 1,712 , and Velva, 1,$170 ; 39$ other incorporated communities had populations of less than 1,000 .

Minot is a transportation and distribution center. Many of the smaller towns are also located along railroads, but all towns except Minot are essentially shopping centers and communities of farm residences. Since automobile travel has become common and schools have been centralized, the population of the towns has been swollen by the influx of farmers who, preferring town life in winter, commute to their fields and perhaps move out to their farms in summer. Abandoned farm houses surrounded by well-kept fields of grain are common sights. 


\section{TRANSPORTATION}

The area is served by the Great Northern Railway, which crosses the area from east to west, and by the Minneapolis, St. Paul, and Sault Ste. Marie Railroad, which extends diagonally across the area from Balfour on the southeast through Woburn (south of Flaxton) on the northwest. Many of the towns are connected by trunk or spur lines.

Three Federal highways cross the area. U. S. Highway 2 crosses the central part of the area from east to west and follows closely the main line of the Great Northern Railway. U. S. Highway 52 extends from the southeast corner of the area through Minot northwestward through Kenmare, Bowbells, and Flaxton. U. S. Highway 83 crosses the central part of the area from south to north through Minot. These three highways are paved throughout most of the area. Several State highways are gravel surfaced and can be traveled during most of the year. In addition, nearly every square mile and some quarter sections are bounded by access roads, most of which are graded and many of which are also graveled.

There is daily airline service between Minot and Bismarck, the State capitol. Owing to a fairly high proportion of good flying weather and long distances to metropolitan centers, travel by light airplanes is increasingly common. Some of the smallest communities have landing strips with minimum service facilities.

\section{INDUSTRY}

The area is an important producer of wheat, flax, and other grains. Diversified dry farming was the rule in the past, but, with the advent of more efficient machinery, controlled prices on farm products, and migration of rural youth to cities, broad-scale "onecrop farming" is becoming dominant. Lignite coal is mined in several localities in the area ; it is mostly consumed locally for domestic uses.

\section{GENERAL SETTING}

\section{PHYSIOGRAPHIC PROVINCES}

The northeast escarpment of the Max moraine forms the boundary between the Great Plains province and the Western lake section of the Central Lowland province (fig. 1). The part of the Great Plains province that lies within the mapped area is the glaciated Missouri Plateau, or, more specifically, the Coteau du Missouri (U. S. Geog. Board, 1933, p. 238), which is the subdivision of the Missouri Plateau that includes the Max moraine. Hence, except for the Max moraine, all of the mapped area is in the Central Lowland.

\section{TOPOGRAPHY}

The area can be separated into three fairly distinct topographic divisions: (1) the high hummocky Max moraine in the southwest part of the area, (2) the gently undulating ground moraine plain that composes all the central part, and (3) the nearly flat featureless area to the east, once covered by glacial Lake Souris. These topographic divisions are shown on plate 1. The highest point has an altitude of about 2,500 feet and is in Burke County, along the western edge of the mapped area. The lowest point is 1,410 feet, in the Souris River valley at the International Border in Bottineau County. Therefore, the total relief is about 1,100 feet.

\section{MAX MORAINE}

The Max moraine, a belt 15-20 miles wide of numerous hills and undrained depressions, trends southeastward from Canada across the International Boundary at the North Dakota-Montana border into and across the mapped area. This conspicuous topographic feature has long been referred to by most workers in the region as the Altamont moraine. It was supposed to correlate with a moraine named by Chamberlin (1883, p. 378-393) for Altamont, S. Dak. However, none of these workers made detailed studies to determine whether or not the moraine in the Souris River area is the same moraine as the one at Altamont. Also, it is now known with some certainty that the hummocky belt of hills in the mapped area constitutes several moraines. Recent work by Howard, Gott, and Lindvall $(1946$, p. 1204-1205), by Witkind (1958), and by others has demonstrated that the last ice sheet in this region extended southwest beyond the Max moraine. Moreover, bedrock has been found by the writer and many recent workers at enough places in the morainal belt to indicate that much of its relief may reflect a bedrock upland, and that the glacial drift in many places is no thicker than much of the ground moraine to the northeast. For these and other reasons Townsend and Jenke (1951, p. 842-858) proposed that this morainal belt be called the Max moraine.

Except where intermittent streams have worked headward a few miles back from the escarpment, drainage on the Max moraine is almost completely unintegrated. In most places the northeast margin of the moraine is much more distinct than the southwest margin. The northeast slope ranges from a relatively abrupt scarp 150 feet high to an indistinct transition zone between the Max moraine and the ground-moraine plain. In places the transition is so imperceptible that the Max moraine can be distinguished only by its higher altitude and unintegrated drainage. 


\section{GROUND-MORAINE PLAIN}

As viewed from the Max moraine, the groundmoraine plain appears to be nearly flat and featureless. Closer inspection shows that it is not flat but has gently undulatory topography characterized by numerous undrained saucer-shaped depressions and, to a lesser extent, small mounds and ridges. Local relief is generally less than 30 feet and in many places is less than 10 feet. The chief modifying features are the valleys of the Souris and Des Lacs Rivers, which in most places are 100-175 feet deep. Other modifying features are glacial outwash channels, commonly 5-30 feet deep and trending mostly at right angles to the regional slope; glacial diversion channels; and several kinds of stratified ice-contact features. The ice-contact features include numerous kames and eskers and, in the southeastern part of the area, linear ridges that are believed to be unusually elongated drumlins. Near the northeast escarpment of the Max moraine the ground-moraine plain slopes in most places 50-80 feet per mile northeast. This slope decreases to about 40 feet per mile near the Souris and Des Lacs Rivers and to 20 feet or less northeast of these rivers.

\section{GLACIAL LAKE SOURIS AREA}

The bed of glacial Lake Souris is nearly flat. Its chief modifying features are sand dunes, some of which are 50 feet or more high, and fairly numerous depressions, which commonly contain lakes. The Souris River has not modified the topography in this area as much as where it crosses the ground-moraine plain. It flows in a channel that is nowhere more than 100 feet lower than the surrounding terrain, and in a considerable part of its course it is hardly entrenched at all. The bed of the former lake slopes a few feet per mile toward the Souris River.

\section{DRAINAGE}

Much of the total area has unintegrated or only partly integrated drainage. The Souris River and its tributary, the Des Lacs River, are the chief drainage courses. Antler Creek, a small stream in a channel about 15 feet deep, meanders along the International Boundary north of the town of Antler but drains only a small tract in the United States. The Wintering River in the southeast part of the area is a small stream whose tributaries head in shallow intermittent lakes; it has a perennial flow only near its mouth. All other streams are intermittent.

The Souris River flows into the United States from Canada near the northwest corner of Renville County.
Thence, it flows southeast nearly to Velva. At Velva it bends northeast, and farther downstream it bends more northward until it makes a complete half circle and reenters Canada northeast of Westhope in Bottineau County. This segment of the river is known as the Souris River loop, and the area within the loop as the Souris loop area.

The Souris River is an underfit stream in a large valley. In meandering back and forth it has produced a very complex meander pattern. Its oversized valley was cut when the river was swollen with glacial melt water, as a result of which the valley is broad, generally flat floored, and, except in the glacial Lake Souris area, incised 100-150 feet lower than the upland surface.

The alluvial floor of the Souris River valley is nearly flat except where modified by meander scars and alluvial fans. Its width ranges from half a mile, where the Souris River enters the United States, to as much as a mile farther downstream. Its average width is about three-fourths of a mile.

Upstream from the mouth of the Des Lacs River, the Souris River valley floor is partly covered by natural and artificial lakes. The largest of these, Lake Darling, is about 20 miles long and 15 feet deep. Downstream from the mouth of the Des Lacs River, there are only a few small artificial lakes. The meander pattern, especially in the vicinity of Minot, is exceedingly complex.

Upstream from the mouth of the Des Lacs River, the Souris River valley is incised to a depth of about 150 feet into what appears to have been a preexisting shallow sag, 2-3 miles wide, in the upland surface. The tributaries of this segment of the river are few and short. Most head 1-2 miles back from the valley floor along the rim of the sag. Below the confluence with the Des Lacs River, the Souris River flows in a steepwalled valley as far as the west shoreline of glacial Lake Souris. The valley is deepest near Minot, where the southern wall is about 200 feet high and the northern wall is about 150 feet high. The difference in altitude of the two walls is due to a northeast slope of the adjacent upland. Long steep-sided tributaries, some of which head in the Max moraine, are incised in the south valley wall. In contrast, only a few short tributaries are carved in the north valley wall because the northeast slope of the upland drains the water away from this side of the valley. The part of the valley extending from the west shoreline of glacial Lake Souris downstream to Upham is very shallow and can scarcely be delimited from the floor of the glacial lake. Downstream from Upham, the valley deepens 
gradually to about 100 feet at the International Boundary.

The average gradient of the Souris River valley within the mapped area is about 1.2 feet per mile. The slope, however, is not uniform. From the International Boundary to the mouth of the Des Lacs River, the gradient is about 1 foot per mile; from the mouth of the Des Lacs River to the west shoreline of glacial Lake Souris, the gradient is about 2.3 feet; from the west shoreline of glacial Lake Souris back into Canada, it is about 1.3 feet. Because of its complex meanders, the river has a considerably flatter gradient than the valley.

The Des Lacs River heads in Canada about 2 miles north of the International Boundary. It flows southeastward about 75 miles and joins the Souris River near Burlington, about 7 miles northwest of Minot.

The alluvial floor of the valley of the Des Lacs River, like that of the Souris River valley, is mostly flat except where modified by alluvial fans that extend out from the larger tributaries. The Des Lacs River is entrenched about 15 feet below the valley floor and has a fairly complex meander pattern. A series of interconnected lakes, mostly less than 6 feet deep, cover nearly all the valley floor from the International Boundary south for about 33 miles. The lake levels are controlled by low dikes. During spring, the lakes are fed chiefly by upstream runoff. During the remainder of the year, most of the flow originates from spring-fed tributaries.

The valley of the Des Lacs River is steep walled from the southern part of the Bowbells quadrangle to the mouth of the river. The maximum difference in elevation between valley floor and upland is near Donnybrook, where the southwest valley wall is about 225 feet high and the northeast valley wall is about 200 feet high. A few miles south of Bowbells, the upland is about 150 feet above the valley floor. 'From there upstream to the International Boundary, the valley is flanked by several fluvially cut benches as much as 2 miles wide. The lowest bench is less than 50 feet above the level of the lake that covers the valley floor; the highest bench on the southwest side of the valley is about 100 feet above lake level; that on the northeast side is about 70 feet.

About 2 miles north of the International Boundary, the inner valley of the Des Lacs River ends rather abruptly. A scoured wide shallow trench, graded to the benches in the Bowbells quadrangle, continues about 5 miles northwestward and grades to a terrace level along the Souris River valley. From the Inter- national Boundary south to near Kenmare, the valley walls are remarkably smooth and tributaries are few and short. From Kenmare downstream, the valley walls are less smooth. Large tributaries enter from the southwest; elsewhere, smaller auxiliary drainage channels modify the valley walls.

The gradient of the valley of the Des Lacs River is markedly steeper than that of the Souris River valley, except for the northern segment, which has almost no gradient. The southern part of the valley slopes about 6 feet per mile throughout its 35-mile length. In this distance the altitude of the floor decreases from 1,775 feet to about 1,565 feet, a change as great as that of the 170-mile segment of the Souris River south of the International Boundary.

Streams in the glacial ice-marginal outwash channels and diversion channels flow intermittently. Many trend southeast, or nearly at right angles to the regional slope, until they reach the west shoreline of glacial Lake Souris. Upon reaching the shoreline the streams are not confined by channel walls and flow east and northeast down the regional slope to drain into the Souris River. Of these streams, Cut Bank Creek, which heads in Canada, probably carries the largest runoff. It flows in an inner trench about 15 feet deep in the floor of Cut Bank Creek channel. Spring Coulee, Little Deep Creek, and Egg Creek are other intermittent streams incised 5-15 feet in the floors of outwash channels bearing their names. Most other outwash channels have insignificant flows.

Diversion channels southeast of Velva slope away from the Souris River and carry little runoff. Where diversion channels head at the edge of the Souris River valley, their floors have been incised by Recent tributaries of the river. Some of these tributaries have worked headward 2-3 miles and reversed drainage in these parts of the diversion channels.

Integrated drainage on the Max moraine is almost totally lacking except for a narrow strip along the escarpment. Water drains into depressions between the innumerable knobs and hills that dot the area. Hence, many depressions contain shallow ponds and lakes. The largest of these lakes is Carpenter Lake, about 1.5 miles long and one-half mile wide, about 7 miles south of Tagus along the western edge of Ward County.

Drainage on the ground-moraine plain, in general, is more integrated than on the Max moraine. The Souris and Des Lacs Rivers and their tributaries are the chief streams. Most of the remaining streams follow ice-marginal outwash channels. However, areas more than 1 mile from these streams, and some areas 
even less than 1 mile, lack integrated drainage. One such area is between the Souris and Des Lacs Rivers. It is a hummocky terrain of knobs and depressions where, except in a narrow strip along the valleys, runoff flows into the nearest undrained depressions.

The bed of glacial Lake Souris is drained only by the Souris River and a few intermittent streams that head mostly on the ground-moraine plain. Most water in this area soaks into permeable lake deposits or drains into shallow lakes whose water levels fluctuate seasonally and from year to year. Most of the lakes are dry at times.

\section{PREVIOUS PUBLISHED WORK}

Few previous detailed geologic studies have been made in the Souris River area. Geologic maps had not been made for much of the area prior to the writer's studies, and those existing were generally of small scale, were published many years ago, or were slanted toward one kind of geology or commodity.

In 1895, Upham (1895, p. 267-272) briefly described the area covered by glacial Lake Souris. His map of glacial Lake Souris, on a scale of 20 miles to the inch, coincides more closely with the writer's map than any others known, although the limits of the lake area shown on his map are considerably greater than those shown on plate 1 .

In connection with lignite studies by the North Dakota Geological Survey, Wilder and Wood (1902, p. 84-146) described the geology of Ward County and adjacent areas. Their report is an excellent source of information concerning not only the location of mines and other pertinent data on lignite, but also other phases of geology. Leonard (1904) briefly described parts of the Souris River area in a general publication on the geology of the State. Leonard later (1908, p. 244-254) included a short account of the Bottineau gas field in the northeast part of the Souris River area in another general paper. In 1925, Leonard, Babcock, and Dove described in considerable detail the lignite deposits of Ward and Burke Counties. In connection with ground-water studies of North Dakota, Simpson (1929) furnished valuable background for the writer's work, although his report contains no geologic maps. The last work prior to the writer's mapping was by Andrews (1939), who mapped the geology and coal resources of the Minot area, including the Minot, Sawyer, Benedict, Kongsberg, and Balfour quadrangles.

After completion of the field work on which this publication is based, the writer (1953) described the geology of the Velva quadrangle, and the writer and Kaye (1953) described the geology of the Bowbells quadrangle. In addition, maps of most of the quadrangles of the Souris River area were placed in open file by the writer soon after completion of the field work in those quadrangles. The facts contained in all the above-mentioned publications are consolidated in this paper. Townsend, who mapped an adjacent area to the west at the same time the writer mapped the Souris River area, described the geology of the Columbus (1951), Noonan (1954a), Crosby (1954b), and Portal (1954c) quadrangles. Many references are made by the writer to the geology in these four quadrangles.

\section{DESCRIPTIVE GEOLOGY}

Surficial deposits of Pleistocene and Recent age mantle nearly the entire area. Except for rocks in two outcrops of possible Late Cretaceous age, all exposed bedrock is of Tertiary age. Upper Cretaceous rocks, however, probably underlie surficial deposits in the eastern part of the area. Knowledge of all other preTertiary rocks is based on drilling logs or on nearby exposures of these rocks. In the descriptions that follow, bedrock is separated into the following categories: (a) rocks of pre-Late Cretaceous age, (b) Upper Cretaceous rocks, and (c) Tertiary rocks.

Figure 2 is a bedrock map of northwest and northcentral North Dakota. It includes not only the Souris River area, which was mapped in detail, but also a much larger area to the east, south, and west. The additional area was included because of the scanty bedrock data heretofore available for this part of the State. Previously, only a small-scale generalized map by Kline (1942, p. 340, fig. 2 ) had been available, which showed the Fort Union formation, the Hell Creek formation, and the Fox Hills sandstone as being in this area; but figure 2 shows the areas to be underlain by Pierre shale, Fox Hills sandstone, Cannonball and Tongue River members of the Fort Union formation, and the Golden Valley formation. Not only do the two bedrock maps differ as to what formations are present, but the areal distribution of the formations is different. Most of the area is blanketed by thick surficial deposits, and the position of the contacts can be refined only as more subsurface data become available. All formations shown on the map are described in the present report except the Golden Valley formation, which was not seen by the writer but which reportedly caps three small areas in the southwestern part of Mountrail County. The formation was first reported by Benson and Laird (1947, p. 1166-1167); it later was described in more cletail by Benson (1952, p. 68-93). 


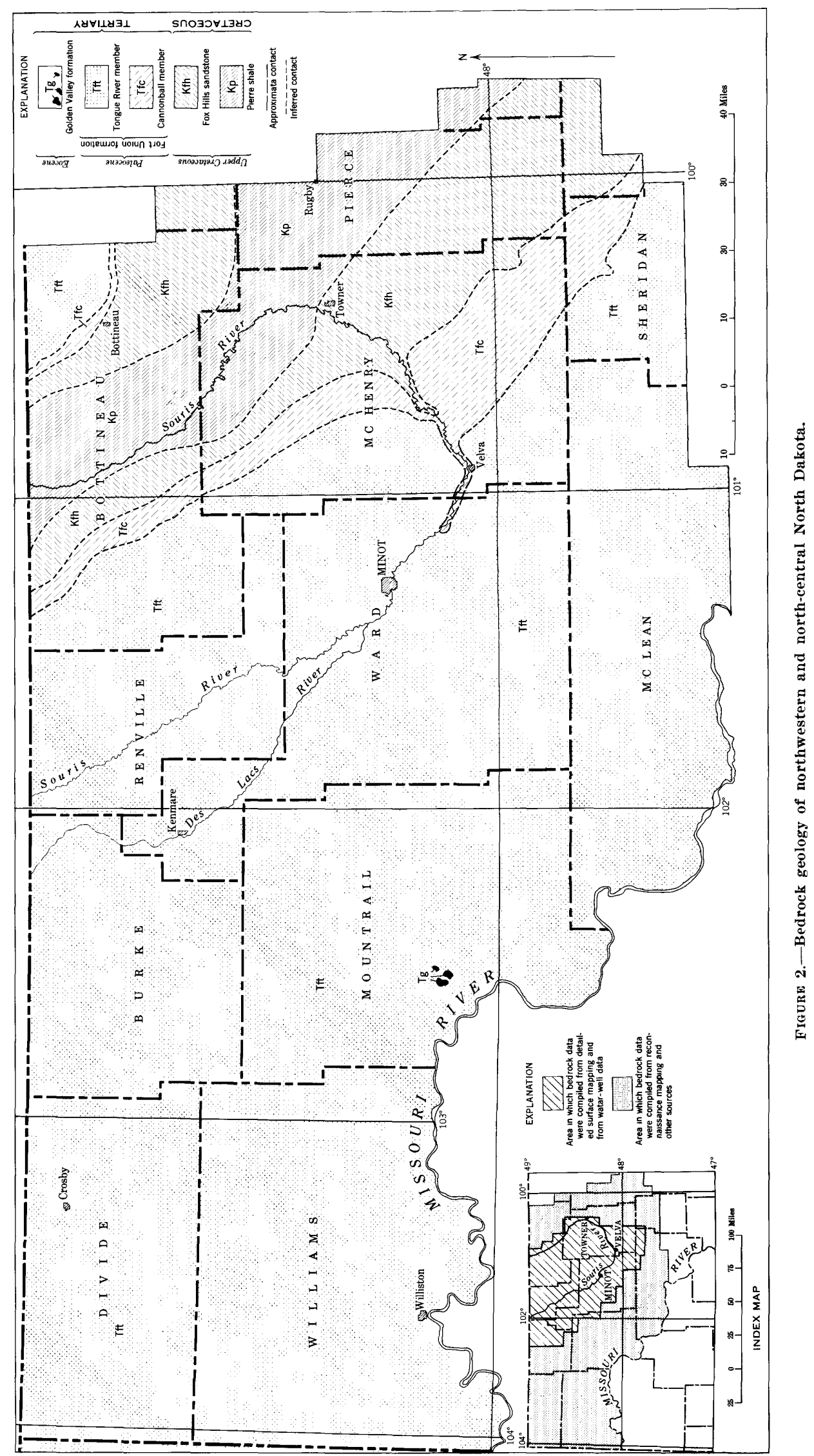




\section{ROCKS OF PRE-LATE CRETACEOUS AGE}

Rocks older than Tertiary in age are not exposed in the Souris River area except possibly at one locality. This possible exception crops out along the valley wall of the Souris River in McHenry County near Verendrye, and it may be Fox Hills sandstone of Late Cretaceous age. Rocks of Late Cretaceous age are exposed in the valley of the Souris River a few miles north of the International Boundary, as well as southeast of the Souris River area, and probably underlie surficial deposits in the eastern part of the area.

At the time of mapping, knowledge of the rocks of pre-Late Cretaceous age was based on $\operatorname{logs}$ of six wells drilled for oil. Only one of these, the J. H. Kline well 1 , was drilled while fieldwork was in progress. Only one other, the Des Lacs Western Blum well 1, had a $\log$ that appeared reliable. Between the time mapping was completed and the spring of 1952, six additional wells were drilled; their locations are shown in figure 17. Much more current and detailed subsurface information than is presented here is obtainable from the North Dakota Geological Survey.

\section{J. H. KLINE WELL 1}

In the fall of 1948, the Dewey Price Co. started drilling the J. H. Kline well 1, 31/2 miles southeast of Carpio on the valley floor of the Des Lacs River, in the SE $1 / 4$ sec. 16, T. 157 N., R. 85 W. at a surface altitude of 1,679 feet. In November 1949 , the well was abandoned at a depth of 8,435 feet. Samples were collected in the field at 5- or 10-foot intervals by J. Hiram Smith and the writer, and tentative stratigraphic correlations were made. Cuttings from the surface down through the Jurassic system were studied by W. A. Cobban. S. F. Fox, Jr., of Princeton University studied the Foraminifera of the Cannonball member of the Fort Union formation. Constance L. Nieschmidt of the U. S. Geological Survey studied the cuttings from the base of the Jurassic system to the bottom of the hole. The following $\log$ is the result of the above work. Studies on cuttings from the well were also made by Laird (1952b, p. 1-31). Correlations of the preRierdon Jurassic stratigraphy in this well with that in other wells in the Williston basin and northern Montana were made by Nordquist $(1955$, p. $96-106)$. In addition, Nordquist proposes that the name Nesson formation of Jurassic age be adopted and that the formation be divided into the Poe evaporite member, the Picard shale member, and the Kline (from the Kline well) member. He further proposes that the Piper formation of Jurassic age be divided in ascending order into the Tampico shale member, the Firemoon limestone member, and the Bowes member.
Measured section of the J. H. Kline well 1 (Dewey Price Co.) in the SE1/4 sec. 16, T. 157 N., R. 85 W., Ward County, N. Dak.

[Interpretation to base of Jurassic by W. A. Cobban and H. R. Christner; interpretation from top of Triassic to bottom of hole by Constance L. Nieschmidt]

Surface altitude, 1,679 feet.

Recent and Pleistocene. Glacial drift :

Sand, buff, coarse.

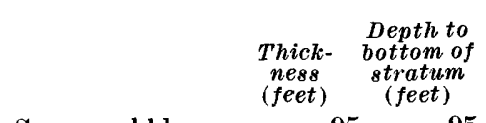

Paleocene.

Fort Union formation.

Tongue River member :

Lignite, black

(Sand and gravel, caved from above?) --

Sandstone and siltstone, gray, finegrained, soft, clayey-................

Lignite, black

Siltstone and shale, gray, soft, clayey

Sandstone, gray, fine-grained, soft, clayey

Siltstone and shale, gray, soft, clayey; includes a little lignite-...-...--..-

Sandstone, light-gray, fine-grained.-.--

(Sand and gravel, caved from above?) -

Sandstone, siltstone, and shale, gray, fine-grained, soft, clayey ; apparently considerably interbedded; includes a little lignite and soft plant-bearing

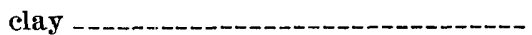

Sandstone, medium-light-gray, finegrained, hard, calcareous_..........-

Fort Union formation.

Ludlow and Cannonball members :

Shale, medium-gray, soft, silty ; includes a little sandstone, and Foraminifera identified by S. F. Fox as of Cannonball. age

Sandstone, medium-gray, very fine grained, calcareous._.................

Siltstone and shale, medium-gray, soft, sandy

Sandstone, light- to medium-gray, fineto medium-grained

Shale, medium-gray, soft, silty_-_-_-_--

Sandstone, siltstone, and shale, mediumgray, soft, clayey

Sandstone, light-medium-gray, finegrained, calcareous, hard._-_...-..--

Siltstone and shale, medium-gray, soft; contains some carbonaceous partings and a little light-gray sandstone, and some gray silty bentonite at 700-705 feet

Cretaceous.

Hell Creek formation:

Sandstone, light-medium-gray, finegrained, fairly soft; contains abundant silt cement.

Sandstone, raedium-gray, fine-grained, soft, clayey ; contains partings of medium-gray siltstone
100

133

143

149

165

170

208

214

245

300

$\mathbf{3 5 0}$

435

470

510

530

587

670

680

80 


\begin{tabular}{|c|c|c|}
\hline $\begin{array}{l}\text { etaceous-Continued } \\
\text { Hell Creek formation-Continued }\end{array}$ & $\begin{array}{l}\text { Thick- } \\
\text { ness } \\
\text { (feet) }\end{array}$ & $\begin{array}{l}\text { Depth to } \\
\text { bottom of } \\
\text { stratum } \\
\text { (feet) }\end{array}$ \\
\hline \multicolumn{3}{|l|}{$\begin{array}{l}\text { Sandstone, siltstone, and mudstone, me } \\
\text { dium-gray, soft }\end{array}$} \\
\hline Siltstone, medium-gray, soft........... & 30 & 855 \\
\hline Bentonite, greenish-gray, silty & $\mathbf{5}$ & 860 \\
\hline (Sample missing) & 45 & 905 \\
\hline Shale, medium-gray, soft, silty & 10 & 915 \\
\hline \multicolumn{3}{|l|}{ Fox Hills sandstone: } \\
\hline $\begin{array}{l}\text { Sandstone, light-gray, fine-grained, } \\
\text { calcareous }\end{array}$ & 25 & 940 \\
\hline $\begin{array}{l}\text { Shale, dark-medium-gray, soft, silty; } \\
\text { contains carbonaceous specks.-- }\end{array}$ & ; & 960 \\
\hline Shale, dark-medium-gray; includes some & & \\
\hline gray siltstone and clayey sandstone-- & 25 & 985 \\
\hline $\begin{array}{l}\text { Sandstone, whitish- to medium-gray, } \\
\text { fine-grained, calcareous, hard.- }\end{array}$ & 10 & 995 \\
\hline $\begin{array}{l}\text { Siltstone, light-medium-gray, soft, } \\
\text { shaly; contains fine white mica }\end{array}$ & 35 & 1,030 \\
\hline $\begin{array}{l}\text { Siltstone and shale, light-medium-gray, } \\
\text { soft }\end{array}$ & 20 & 1,050 \\
\hline $\begin{array}{l}\text { Shale, light-medium-gray, silty, soft; } \\
\text { contains some partings of siltstone } \\
\text { and a few shell fragments and ostra- } \\
\text { codes }\end{array}$ & 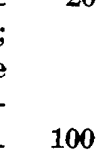 & 1,150 \\
\hline \multirow{3}{*}{\multicolumn{3}{|c|}{$\begin{array}{l}\text { Pierre shale: } \\
\text { Shale, medium- to dark-medium-gray; } \\
\text { glauconitic at top; contains a little } \\
\text { white aragonite and a few Foramini- } \\
\text { fera }\end{array}$}} \\
\hline & & \\
\hline & & \\
\hline $\begin{array}{l}\text { Shale, medium-gray; contains a little } \\
\text { white bentonite all through samples, } \\
\text { and Foraminifera, particularly abun- } \\
\text { dant from } 1240 \text { to } 1245 \text { feet }\end{array}$ & & \\
\hline $\begin{array}{l}\text { dant from } 1240 \text { to } 1245 \text { feet } \\
\text { Shale, light-medium-gray, firm ; con- }\end{array}$ & 80 & 1,270 \\
\hline tains a few Foraminifera & 70 & 1,340 \\
\hline $\begin{array}{l}\text { Shale, light-gray, hard, massive (prob- } \\
\text { ably claystone); contains a little ben- } \\
\text { tonite from } 1400 \text { to } 1410 \text { feet and }\end{array}$ & & \\
\hline some Foraminifera & 90 & 1,430 \\
\hline $\begin{array}{l}\text { Shale, medium-light-gray, firm; con- } \\
\text { tains rather abundant Foraminifera, } \\
\text { a little light-gray bentonite; contains }\end{array}$ & & \\
\hline Baculites sp. from 1460 to 1480 feet_- & 70 & 1,500 \\
\hline $\begin{array}{l}\text { Shale, light-medium-gray, softer than } \\
\text { overlying shales; contains a few For- } \\
\text { aminifera, and a little bentonite from }\end{array}$ & & \\
\hline 1530 to 1540 feet & 40 & $\mathbf{1}, 540$ \\
\hline $\begin{array}{l}\text { Shale, light-medium-gray ; c o n t a in s } \\
\text { brown ironstone, gray silty bentonite, } \\
\text { and white aragonite, and a piece of } \\
\text { dark-brown phosphatic nodule from }\end{array}$ & & \\
\hline 1580 to 1590 feet & 70 & 1,610 \\
\hline $\begin{array}{l}\text { Shale, light-medium-gray, soft, bento- } \\
\text { nitic }\end{array}$ & 50 & 1,660 \\
\hline $\begin{array}{l}\text { Shale, light-medium-gray, soft, slightly } \\
\text { bentonitic; contains brown ironstone } \\
\text { and some bentonite }\end{array}$ & 140 & 1,800 \\
\hline $\begin{array}{l}\text { Shale, light-medium-gray; c on ta ins } \\
\text { abundant brown ironstone and gray } \\
\text { to creamy bentonite- }\end{array}$ & 40 & 1,840 \\
\hline Shale, medium-dark-gray & $\mathbf{3 0}$ & 1,870 \\
\hline
\end{tabular}

Cretaceous-Continued

Pierre shale-Continued

Shale, light-medium-gray, soft; much creamy-white bentonite

Shale, light-medium-gray, soft; contains brown ironstone and some bentonite--

Shale, light-medium-gray, sofit_-_.-_-_--

Shale, light-medium-gray, soft; contains white bentonite, and some ironstone from 2120 to 2130 feet.

(Sample missing)

Shale, light-medium-gray, soft; contains much ironstone and some bentonite--

Niobrara formation:

Shale, medium-dark-gray, calcareous; contains abundant white specks and some Foraminifera and fish bones..-

Shale, dark-gray to medium-dark-gray, calcareous; contains fewer white specks. Fragments of dark-gray calcareous septarian concretions with pale-yellow calcite seams occur from 2410 to 2420 feet. Contains some gray to white bentonite. Below 2460 feet, oyster fragments and Inoceramus prisms are common.

Carlile shale :

Shale, dark-gray to medium-dark-gray; contains calcareous septarian concretions from 2600 to 2610 feet, and dark-gray calcareous concretions with white specks from 2650 to 2660 feet--

Shale and siltstone, medium-gray to pale-yellowish-brown, very finely micaceous; contains bits of carbona-

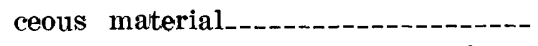

Shale, dark-gray to medium-gray, firm; some parts silty

Shale, dark-gray, firm; contains much light-gray shaly bentonite from 2780 to 2790 feet.

$210 \quad 2,700$

$20 \quad 2,760$

Greenhorn limestone:

Limestone and shale, gray finely crystalline limestone in thin lenses or layers separated by dark-gray calcareous shale that commonly contains tiny white specks; contains fish bones and scales, and much creamy bentonite

Limestone, medium-light-gray to medium-gray, finely crystalline, thin-bedded; contains abundant Inoceramus fragments, oysters, and fish remains_

Shale, dark-gray, calcareous, massive; contains abundant white specks, some lenses of gray finely crystalline limestone, and some creamy finely micaceous bentonite

Limestone and shale, from 2795 to 2815 feet; contains a few Foraminifera..Shale, dark-gray, calcareous
$25 \quad 2,890$

102,900 
Cretaceous-Continued

Graneros shale :

Shale, medium-dark-gray, fissile; contains an occasional fish scale or bone and some bluish to white bentonite

Shale, dark-gray; contains a few streaks of light-gray very fine grained calcareous sandstone and occasional fish bones and scales

Shale, dark-gray; contains some lightgray glauconitic very fine grained sandstone as thin partings

Shale, dark-gray; contains an occasional fish bone or scale

Shale, dark-gray; includes some green very fine grained glauconitic sandstone

Shale, drak-gray

Dakota sandstone:

Sandstone, light-gray, very fine grained, apparently thin-bedded with darker silty partings ; occurs chiefly as colorless quartz grains with a little white mica

Sandstone, very light gray, fine- to medium-grained, rather poorly sorted.-

s a nds t o ne, light-gray, very fine grained; contains dark shale partings

Siltstone, very light gray to lightgreenish-gray; contains light-brown spheres of siderite and tiny pyrite crystals; includes some very light gray, very fine grained sandstone

Sandstone, very light gray, fine- to coarse-grained, porous; some parts pyritic

Siltstone, white to very light gray, hard, pyritic -...--

Sandstone, very light gray, fine- to coarse-grained ; some good porosity --

Sandstone and siltstone, light-gray to greenish-gray, very fine grained, hard_

$\mathrm{S}$ a n d s t o n e, light-gray, fine-grained, porous

Siltstone, medium-gray, clayey

Sandstone, light-gray to whitish, fine- to medium-grained with some coarse streaks, massive, porous; almost wholly colorless subangular quartz grains

Shale, siltstone, and sandstone, mediumto light-gray, very fine grained, much interbedded

Shale, medium-gray, silty to very finely sandy; contains very fine grained shaly sandstone partings

Sandstone, whitish, fine to mediumgrained with some coarse poorly sorted partings; chiefly colorless quartz grains

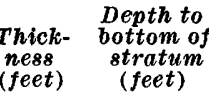

$\begin{array}{cc}\text { ness } & \text { stratum } \\ \text { feet }) & \text { (feet) }\end{array}$

Jurassic ( ?)

Morrison (?) formation :

Clay shale, medium-dark-gray, soft...-

Clay shale, greenish-gray, waxy, interbedded with pale-green to whitish siltstone and shaly very fine grained sandstone

Sandstone, very light gray, pale-green, or salmon, very fine grained, calcareous; contains thin partings of green, greenish-gray, or gray shale or white micaceous laminae

Jurassic.

103,040

3153,355

$5 \quad 3,360$

$50 \quad 3,410$

153,425

$5 \quad 3,430$

103,440

3,455

$5 \quad 3,460$

30

10

30

20

30

3,550

3,580

70

3,650

20

3,670

70

3,740

30
Ellis group :

Sandstone, light-gray, fine-grained, calcareous, slightly glauconitic, porous ; contains medium-gray micaceous shale partings ; upper 10 feet oolitic.-

Sandstone, light-gray, very fine grained, calcareous, slightly glauconitic; contains greenish shale partings

Shale, medium-greenish-gray, silty to clayey, calcareous, contains fragments of Gryphwea shells in upper 10 feet and some highly glauconitic shale in lower 5 feet

Sandstone, light-gray, very fine grained, calcareous; in very thin layers separated by films of greenish-gray shale_

Limestone, ruedium-brownish-gray, compact; in thin layers separated by dark-gray and greenish-gray shale and slightly g]auconitic silty partings_.--

Limestone, medium-brown mottled white, finely crystalline; contains fragments of pelecypods

Shale, medium-greenish-gray, calcareous ; contains thin layers of light-gray dense limestone; some oyster frag-

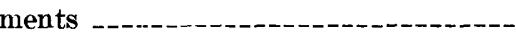

Shale, medium-gray, calcareous ; contains medium-gray limestone layers_-

Shale, medium-greenish-gray to medium-grayish-red with traces of brownish-yellow or gray mottling ---

Shale, brownish-yellow with gray to greenish-gray mottling and grayishred with gray to yellowish mottling, slightly calcareous; some pink gypsum - - -

Sandstone, light-brownish-gray, very fine grained, hard, calcareous; contains fragments of pelecypods

Shale, greenish-gray, silty

Limestone, brownish-gray, sandy, hard; contains fragments of fossils.-_-_-_--

Shale, medium-greenish-gray, silty_-_--

Limestone, light-brown to brownishgray, hard, somewhat sandy, fossiliferous; in thin layers separated by greenish-gray silty shale
Thick- bepth to ness
(feet) $\quad$ (feet)

$55 \quad 3,825$

$15 \quad 3,840$

$70 \quad 3,910$

$90 \quad 4,000$

$30 \quad 4,030$

$20 \quad 4,080$

254,105

$5 \quad 4,110$

$65 \quad 4,175$

$35 \quad 4,210$

$70 \quad 4,280$

$30 \quad 4,310$

$5 \quad 4,315$

104,325

$5 \quad 4,330$

$10 \quad 4,340$

154,355 
Jurassic-Continued

Ellis group-Continued

Shale and siltstone, medium-greenishgray ; contains fragments of belemnites

Shale, medium-gray

Sandstone, very light gray, very fine grained, somewhat glauconitic, shaly_

Shale, gray to greenish-gray

Limestone, light-gray, compact, hard ; contains some patches of white gypsum -...-

Limestone, light-creamy-brown to me dium-gray ; contains some ostracodes_

Shale, medium-gray

Limestone, creamy to pale-gray and pale-brown, compact, hard ; contains a few tiny pelecypods

Shale, medium-greenish-gray mottled by green and pinkish-gray

Limestone, pale-creamy-brown, hard, compact; contains patches of white gypsum

Shale, dark-gray

Dolomite, chocolate-brown, dense, speckled by white gypsum

Dolomite, pinkish, dense; contains patches of white gypsum

Mudstone, medium-gray and greenishgray with maroon mottling

Dolomite, medium-gray to mediumbrown, dense; contains many patches of white gypsum.

Mudstone, maroon to medium-greenishgray

Dolomite, creamy, brown, and gray, with white gypsum patches; interbedded with white, pink, and gray

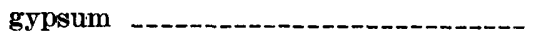

Mudstone, medium-grayish-green with some yellowish and maroon mot-

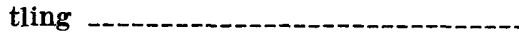

Dolomite, gray, dense; contains white gypsum patches; interbedded with grayish-green shale

Mudstone, medium-gray

Dolomite, light-brownish-gray, pyritic : interbedded with medium-gray pyritic siltstone

Triassic

Spearfish formation :

Siltstone, light-reddish-brown, argillaceous, slightly calcareous; contains streaks and particles of white and pink gypsum

Sandstone, light-reddish-brown, very fine grained, argillaceous, slightly calcareous ; contains streaks and particles of white and pink gypsum...-.

Sandstone, with less gypsum ; contains embedded coarse and very coarse rounded and subrounded light-redThick- $\begin{gathered}\text { Depth to } \\ \text { bottom of }\end{gathered}$ $\begin{array}{cc}\text { ness } & \text { stratum } \\ (\text { feet }) & (\text { feet })\end{array}$

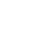

254,380

104,390

$20 \quad 4,410$

$20 \quad 4,430$

\section{0}

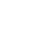

$10 \quad 4,460$

$10 \quad 4,470$

$63 \quad 4,533$

$20 \quad 4,553$

$17 \quad 4,570$

$20 \quad 4,590$

$5 \quad 4,595$

$5 \quad 4,600$

$8 \quad 4,608$

$7 \quad 4,615$

$5 \quad 4,620$

$10 \quad 4,630$

$5 \quad 4,635$

$20 \quad 4,670$

10

4,680
$15 \quad 4,650$

Triassic - Continued

Spearfish formation-Continued

dish-brown grains of quartz, some of

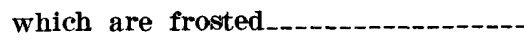

Mudstone, yellowish-gray, olive-gray, and reddish-brown; interbedded with gypsum

Sandstone, light-reddish-brown, very fine grained, argillaceous, calcareous, slightly gypsiferous

Mudstone, light-gray, olive-gray, and

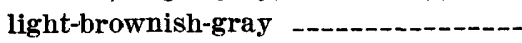

Siltstone, reddish-brown, argillaceous, calcareous, slightly gypsiferous ; interbedded with some light-reddish-brown mudstone - -..-_-

Sandstone, light-reddish-brown, fine grained, argillaceous, calcareous, gypsiferous; contains embedded coarse and very coarse rounded and subrounded quartz grains, which are colorless and light reddish brown....--

Limestone, grayish-orange-pink, medium crystalline; contains embedded medium and coarse subangular quartz grains and is almost a calcareous sandstone

Siltstone, pale-red, slightly calcareous; contains streaks of colorless crystalline gypsum

Sandstone, pale-red, very fine grained, silty, slightly calcareous; contains some particles of colorless gypsum; contains sparse coarse and very coarse subangular quartz grains.

Anhydrite, white, pale-red, and lightreddish-brown streaked; interbedded with reddish-brown calcareous siltstone that contains particles of colorless gypsum

Mississippian.

Charles formation:

Limestone, light-brownish-gray, finely crystalline, silty

Anhydrite, white, pink, and light-red_---

Limestone, light-brownish-gray, finely crystalline, silty

(Sample missing)

Limestone, light-brownish-gray, silty ; contains some particles of colorless gypsum

(Sample missing)

Anhydrite, white, pale-red, and lightreddish-brown streaked

Anhydrite, white; interbedded with yellowish-gray earthy-textured limestone

4,720

Limestone, moderate-yellow-brown and streaked and mottled moderateyellow-brown and grayish-red, cryptocrystalline; contains veinlets filled with some red mineral; contains particles of white anhydrite

Depth to ick- bottom of (feet) $\quad \begin{gathered}\text { stratum } \\ \text { (feet) }\end{gathered}$

$5 \quad 4,815$

4,860 
Mississippian-Continued Charles formation-Continued

Limestone, light-yellowish-gray ; composed almost entirely of limestone oolites, 1-2 $\mathrm{mm}$ in diameter; contains some intercalations of $\mathrm{g}$ y $\mathrm{psum}$ streaked pale-grayish-red and white, fragments of fossils, and uniformly distributed microcavities 1-2 $\mathrm{mm}$ in diameter

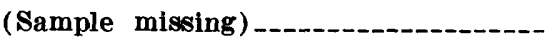

Limestone, light-yellowish-gray, dolomitic; contains sparse limestone oolites 1-2 $\mathrm{mm}$ in diameter, very fine subangular and subrounded quartz grains, fragments of fossils, and uniformly distributed microcavities 1-2 $\mathrm{mm}$ in diameter

(Sample missing)

Limestone, light-yellowish-gray, medium microfragmental ; contains some limestone oolites 1-2 $\mathrm{mm}$ in diameter, and uniformly distributed microcavities 1$2 \mathrm{~mm}$ in diameter

(Sample missing)

Anhydrite, white, yellowish-gray, and pale-grayish-red

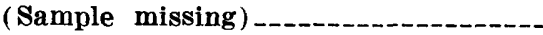

Anhydrite, light-gray, earthy-textured, argillaceous, dolomitic

(Sample missing)

Anhydrite, light-gray microcrystalline, dolomitic

Limestone, dark-yellowish-brown, cryptocrystalline, interbedded with white microcrystalline anhydrite

Limestone, light-yellowish-gray, earthytextured; contains some limestone oolites 1-2 mm in diameter, fragments of fossils, and uniformly distributed microcavities 1-2 $\mathrm{mm}$ in diameter.-.-

Limestone, finely crystalline; interbedded with moderate-yellow-brown medium crystalline limestone

Limestone; interbedded with white fine-

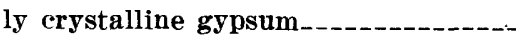
Gypsum, white, finely crystalline...-.Anhydrite, white, finely crystalline--Gypsum, white, finely crystalline ; interbedded with white finely crystalline anhydrite

(Sample missing)

Anhydrite, light-gray, cryptocrystalline Anhydrite, white, finely crystalline

Limestone, m od e r a t e-yellow-brown, coarsely microfragmental and microcrystalline; contains streaks of moderate-yellow-brown anhydrite

Anhydrite, light-gray, cryptocrystalline

Anhydrite, light-yellowish-gray, microcrystalline

Dolomite, light-yellowish-gray, microsaccharoidal
Depth to

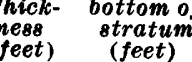
(feet)

Mississippian-Continued Charles formation-Continued

Limestone, yellowish-gray and moderate-yellow-brown, finely crystalline and coarsely microfragmental: contains sparse limestone oolites about 1 $\mathrm{mm}$ in diameter.

Limestone, light-gray, cryptocrystalline; contains a trace of light-gray subchalcedonic chert from 5495 to 5500 feet..

Limestone, yellowish-gray, microcrystalline ; contains sparse limestone oolites about $1 \mathrm{~mm}$ in diameter; contains intercalations of yellowish-gray coarsely microfragmental fossiliferous limestone and uniformly distributed microcavities 1-2 $\mathrm{mm}$ in diameter......
$5 \quad 5,195$ $5 \quad 5,190$

$5, \mathbf{5}, 195$

55,200

$15 \quad 5,215$

$5 \quad 5,220$

$15 \quad 5,235$

55,240

$10 \quad 5,250$

10

5,260

5

5,265

20

5,285

15

5,340

105,350

50

5,400

$15 \quad 5,415$

105,425

$5 \quad 5,430$

155,450

$20 \quad 5,470$

$10 \quad 5,480$
Anhydrite, white, light-yellowish-gray, and light-gray, finely crystalline; contains some gray shale partings from 5515 to 5520 feet and some light yellowish-gray subchalcedonic chert from 5520 to 5525 feet

Anhydrite, light-gray, cryptocrystalline : intercalated with white finely crystalline anhydrite and with moderate-yellow-brown finely crystalline limestone

Limestone, moderate-yellow-brown, medium and coarsely microfragmental; contains some limestone oolites about $1 / 2-1 \mathrm{~mm}$ in diameter

Anhydrite, white and light-yellowishgray, finely crystalline

(Sample missing)

Anhydrite, white and light-yellowishgray, finely crystalline; intercalated with yellowish-gray coarsely microfragmental and finely crystalline limestone

Anhydrite, white and light-yellowishgray, finely crystalline
Limestone, yellowish-gray and moderate-yellow-brown, coarsely microfragmental; contains poorly developed to well-developed limestone oolites 1-5 $\mathrm{mm}$ in diameter from 5645 to 5900 feet, some veinlets of colorless coarsely crystalline calcite from 5695 to 5900 feet, and some microcavities 1-5 $\mathrm{mm}$ in diameter from 5690 to 5900 feet. The microcavities are sparse from 5690 to 5695 feet, less sparse and uniformly distributed from 5695 to 5840 feet, and less numerous but uniformly distributed from $\mathbf{5 8 4 0}$ to 5900 feet. Some of the microcavities are lined with colorless coarsely crystalline calcite from 5695 to 5900 feet. The intervals from $\mathbf{5 7 8 0}$ to $\mathbf{5 7 9 0}$ and 5800 to 5815 feet contain streaks of asphalt, and the interval from 5815 
Mississippian-Continued Mission Canyon limestone, etc.-Continued to 5820 feet contains streaks of asphalt and streaks of limestone that shows light-brown oil stain. The limestone from 5820 to 5843 feet is light brown, oil saturated, and contains some streaks of asphalt.-.----

Limestone, yellowish-gray and moderate-yellow-brown, coarsely microfragmental; contains sparse limestone oolites 1-5 $\mathrm{mm}$ in diameter and is interbedded with light-yellowish-gray and moderate-yellow-brown microsucrosecrystalline dolomitic limestone. Microcavities $1-4 \mathrm{~mm}$ in diameter occur throughout the unit. They are sparse from 5900 to 5920 feet and less sparse and uniformly distributed from 5920 to 5950 feet. The interval from 5900 to 5910 feet contains streaks of asphalt; the interval from 5910 to 5920 feet contains streaks of asphalt and streaks of dolomitic limestone that shows light-brown oil stain; and the interval from 5920 to 5940 feet contains streaks of dolomitic limestone that show light-brown oil stain

Limestone, light-yellowish-gray and moderate-yellow-b r o w n, dolomitic, earthy-textured from 5950 to 5955 feet, microsaccharoidal from 5955 to $\mathbf{5 9 8 5}$ feet; contains some limestone oolites $1 / 2-1 \mathrm{~mm}$ in diameter from 5950 to 5955 feet and some limestone oolites 1-5 $\mathrm{mm}$ in diameter from 5955 to 5965 feet; contains some micropartings of greenish-gray mudstone from 5950 to 5955 feet and some sparse black flakes from 5955 to 5965 feet. Some uniformly distributed microcavities 1-4 $\mathrm{mm}$ in diameter are present throughout the unit, and some of them from 5965 to 5970 feet are filled with gypsum. The limestone shows lightbrown oil stain from 5965 to 5985 feet

Limestone, yellowish-gray, coarsely microfragmental : abundantly fossiliferous, contains numerous uniformly distributed microcavities $1-4 \mathrm{~mm}$ in diameter

Limestone, yellowish-gray, dolomitic : fossiliferous, centains some streaks and partings of white gypsum, and some microcavities $1-4 \mathrm{~mm}$ in diameter, distributed uniformly throughout the unit. The limestone shows lightbrown oil stain and traces of asphalt

Limestone, light-yellowish-gray a n d moderate-yellow-brown, coarsely microfragmental; abundantly fossiliferous, contains pseudo-oolites from 6015
Depth to bottom of stratum (feet)

265

5,900

50

5,950

35

5,985

20

6. 005

10

6,015
(2)

Mississippian-Continued Mission Canyon limestone, etc-Continued Thick- $\begin{gathered}\text { Depth to } \\ \text { bottom of }\end{gathered}$ to 6020 feet and from 6030 to 6050 feet. Sparse microcavities 1-4 mm in diameter occur from 6015 to 6085 feet; Traces of limestone show streaks of asphalt from 6015 to 6085 feet.....--

Lodgepole limestone, 6085 feet:

Limestone, medium-gray, coarsely microfragmental; abundantly fossiliferous, intercalated with medium-gray calcareous shale, contains some uniformly distributed particles of pinkish-gray anhydrite from 6140 to 6160 feet

Limestone, yellowish-gray, microsaccharoidal, dolomitic; intercalated with yellowish-gray coarsely microfragmental fossiliferous limestone ---

Limestone, yellowish-gray and mediumgray, coarsely microfragmental

Limestone, yellowish-gray and mediumgray, coarsely fragmental, and medium-gray, finely crystalline limestone; contains microparting of darkgray shale

Limestone, yellowish-gray, finely crystalline, siliceous; contains some yellowish-gray subchalcedonic and opaque calcareous chert. The silica in the limestone consists of subrounded silt-sized grains of quartz and finely divided quartz and chert in varied shapes. The limestone and chert contain minute black tubes filled with light-colored material.

Limestone, light-yellowish-gray, microcrystalline; interbedded with yellowish-gray subchalcedonic and opaque chert; contains minute black tubes filled with light-colored material, which are numerous from 6460 to 6480 feet.

(Sample missing)

Limestone, medium-light-gray, cryptocrystalline ; interbedded with mediumlight-gray opaque calcareous chert_-.-

(Sample missing)

Limestone, medium-light-gray, cryptocrystalline, interbedded with mediumlight-gray opaque chert

Limestone, yellowish-gray and mediumlight-gray, microcrystalline; interbedded with medium-light-gray and yellowish-gray calcareous and noncalcareous opaque chert; contains grains of glauconite $1 / 4-1 \mathrm{~mm}$ in diameter, and some particles of pyrite $1 / 2-2$ $\mathrm{mm}$ in diameter from 6630 to 6635 feet. However, sample is missing from 6625 to 6630 feet. (Sample missing) 
Mississippian-Continued Englewood limestone.

Shale, brownish-gray, silty, calcareous; contains traces of particles of pyrite $1 / 2-2 \mathrm{~mm}$ in diameter

(Sample missing)

Limestone, brownish-gray microcrystalline, silty

(Sample missing)

Limestone, medium-gray, finely crystalline, silty; contains sponge spicules, some of which are pyritized.

Limestone, as above, minus sponge spicules; contains a trace of dark-gray microfossiliferous chert in which some of the microfossils are pyritized_

(Sample missing)

Limestone, light-yellowish-gray and pale-yellowish-brown, cryptocrystalline and finely crystalline...........

Shale, dark-gray, fissile, of dull luster--

Mississippian and Upper Devonian.

Three Forks shale :

Siltstone, greenish-gray, argillaceous, calcareous ; contains some particles of pyrite about $1 \mathrm{~mm}$ in diameter....---

Limestone, yellowish-gray, finely crystalline; contains fine and medium subangular and subrounded quartz grains; some particles of pyrite about $1 \mathrm{~mm}$ in diameter, sparse grains of glauconite $1 / 2-1 \mathrm{~mm}$ in diameter, and some flakes of dark-gray shale.......-

(Sample missing)

Siltstone, pale-orange, calcareous ; contains some intercalations of greenishgray shale

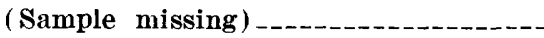

Siltstone, light-yellowish-gray, calcareous; contains some intercalations of greenish-gray shale

Shale, greenish-gray, calcareous

Siltstone, pale-yellowish-brown, calcareous; interbedded with greenish-gray shale

Siltstone as above, but is grayish orange pink in color.

Shale, moderate-brown, silty, calcareous -..-...-

Siltstone, light-brown, argillaceous, calcareous; contains some micropartings of moderate-brown shale

Siltstone, as above, but contains also some greenish-gray shale partings ---

Siltstone, light-orange-pink and lightbrown, calcareous

Shale, moderate-brown

Siltstone, light-orange-pink and lightbrown, calcareous.

Siltstone, yellowish-gray and greenishgray, argillaceous, calcareous. (Samples missing)

Siltstone, yellowish-gray and greenish-
Depth to ness $\underset{\text { Bottratum }}{\text { strat }}$ ness
feet) $\quad$ (feet)

106,650

56,655

$30 \quad 6,685$

56,690

56,695

56,700

56,705

$10 \quad 6,715$

$15 \quad 6,730$
Mississippian and Upper Devonian-Cont. Three Forks shale-Continued gray, argillaceous, calcareous ; contains intercalations of white finely crystalline gypsum

Siltstone, moderate-brown, argillaceous ; contains intercalations of white earthy-textured and finely crystalline gypsum

Anhydrite, white and light-brown; contains intercalations of moderate brown shale

Anhydrite, as above, but contains also intercalations of greenish-gray shale

Shale, greenish-gray, interbedded with anhydrite

Shale, moderate-brown, interbedded with anhydrite

Upper Devonian.

Jefferson formation. (Sloss, 1946, Chart 25)

(Dolomite member) :

Limestone, yellowish-gray and pale yellowish-brown, streaked and mottled, medium microfragmental; contains particles of colorless coarsely crystalline gypsum, and streaks of asphalt from 6975 to 6978 feet

Dolomite, yellowish-gray, finely sucrosecrystalline; slightly silty, calcareous.

Limestone, pale-yellowish-brown, medium microfragmental

Limestone, light-yellowish-gray, finely saccharoidal, dolomitic, slightly silty_

Limestone, light-yellowish-gray, microcrystalline; intercalated with yellowish-gray finely saccharoidal dolomitic limestone from 7025 to 7030 feet; contains prints and fragments of fossils

Shale, pale-red, dolomitic_-_-_.-.--

Dolomite, light-yellowish-gray, microcrystalline

Limestone, pale-yellowish-brown, cryptocrystalline

Limestone, pale-yellowish-brown, medium semimicrofragmental; contains fragments of fossils

Limestone, medium-gray, cryptocrystalline

Limestone, light-brownish-gray, microcrystalline; interbedded with darkyellowish-brown coarsely crystalline gypsum

Limestone, light-gray, microcrystalline : intercalated with white to light-yellowish-brown finely crystalline anhydrite --.---_--.--

Anhydrite, white to light-yellowishgray, finely crystalline

Anhydrite, light-gray, dolomitic.

Limestone, brownish-gray and gray, microcrystalline and medium microfragmental
$40 \quad 7,050$

107,060

$5 \quad 7,065$

$5 \quad 7,070$ 
Upper Devonian-Continued Jefferson formation-Continued

Anhydrite, white to light-yellowishgray, finely crystalline to medium crystalline

Limestone, yellowish-gray and lightbrownish-gray, cryptocrystalline; interbedded with some colorless coarse$1 y$ crystalline anhydrite and some yellowish-gray finely crystalline anhydrite; contains some limestone oolites, sparse microcavities $1-4 \mathrm{~mm}$ in diameter, and some streaks of asphalt

Limestone, light-yellowish-gray crypto-

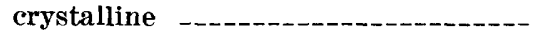

Limestone, light-yellowish-gray, finely saccharoidal, dolomitic; contains some microcavities 1-2 $\mathrm{mm}$ in diameter

Limestone, light-yellowish-gray and moderate-yellow-brown, medium and coarsely semimicrofragmental, dolomitic from $\mathbf{7 1 6 5}$ to $\mathbf{7 1 7 0}$ feet; contains some particles of colorless crystalline gypsum, fragments of fossils some of which are spines or spicules, and some streaks of asphalt

Limestone, light-yellowish-gray, cryptocrystalline, dolomitic

Anhydrite, white and moderate-yellowbrown, finely crystalline

Limestone, yellowish-gray, finely microfragmental; contains some particles of brown cryptocrystalline gypsum ..

Limestone, pale-yellowish-brown, finely crystalline; interbedded with yellowish-gray and pale-yellowish-brown finely crystalline anhydrite

Anhydrite, yellowish-gray and pale-yellowish-brown, finely crystalline

Limestone, light-brownish-gray, cryptoerystalline and medium and coarsely semimicrofragmental; contains fragments of fossils

(Sample missing)

Limestone, light-yellowish-gray, cryptocrystalline

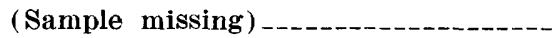

Anhydrite, yellowish-gray, light-gray, and moderate-yellow-brown, finely crystalline, dolomitic ; contains traces of greenish-gray shale from $\mathbf{7 2 7 5}$ to 7290 feet

Anhydrite, moderate-yellow-brown, finely crystalline; intercalated with moderate-yellow-brown finely saccharoidal dolomite: contains traces of yellowgreen shale.

Limestone nember.

Dolonite, light-brownish-gray, finely saccharoidal, calcareous: contains some particles of colorless very coarse-

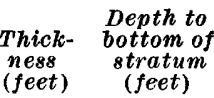

ness $\quad$ stratum

5

57,135

15

7,150

10

7,160

$5 \quad 7,165$

10

7,175

10

10

185

15

7,210

7,215

10

7,225

$30 \quad 7,255$

157,260

$5 \quad 7,265$

$5 \quad 7,270$

20

7,290

$5 \quad 7.295$
Upper Devonian-Continued

Limestone member-Continued

ly crystalline gypsum, and sparse microcavities $1 / 4-2 \mathrm{~mm}$ in diameter...-.

Limestone, light-brownish-gray, cryptocrystalline, dolomitic

Dolomite, light-brownish-gray, finely saccharoidal, calcareous ; contains some particles of colorless very coarsely crystalline gypsum, and fairly numerous microcavities $1 / 4-2 \mathrm{~mm}$ in diameter

Limestone, light-brownish-gray, cryptocrystalline

Limestone, light-yellowish-gray, cryptocrystalline, dolomitic

Limestone, pale-brown, cryptocrystalline; contains spaces $1 / 2-4 \mathrm{~mm}$ in diameter filled with pale-brown very coarsely crystalline gypsum from 7380 to 7385 feet intercalations of white and pale-brown very coarsely crystalline gypsum from $\mathbf{7 4 0 0}$ to $\mathbf{7 4 1 5}$ feet, fragments of fossils from 7385 to 7400 feet, and nicrostreaks of asphalt from 7385 to 7400 feet.

Limestone, pale-yellowish-brown, cryptocrystalline : contains microstreaks of asphalt

Limestone, light-olive-gray, cryptocrystalline

Dolomite, light-yellowish-gray, microsaccharoidal, calcareous

Limestone, light-yellowish-gray, cryptocrystalline; contains some particles of finely crystalline gypsum.

Limestone, yellowish-gray, microsaccharoidal, dolomitic

Limestone, light-gray and brownishgray, microcrystalline

Dolomite, yellowish-gray, finely saccharoidal, calcareous

Limestone, light-brownish-gray microcrystalline .

Limestone, light-gray, cryptocrystalline_

Limestone, yellowish-gray, microsaccharoidal, dolomitic

Dolomite, yellowish-gray, microsaccharoidal, calcareous

(Sample missing)

Limestone, yellowish-gray, cryptocrystalline, dolomitic

Limestone, yellowish-gray, cryptocrystalline; contains veinlets and needleshaped and oblong areas 1-2 $\mathrm{mm}$ in length of light-brown coarsely crystalline gypsum.

Limestone, pale-brown, cryptocrystalline

Limestone, medium-gray, cryptocrystalline

Limestone, brownish-gray, cryptocrystalline
Depth to bottom of ness
feet) (feet)

$20 \quad 7,315$

$10 \quad 7,325$ 
Upper Devonian-Continued

Limestone member-Continued

Dolomite, light-olive-gray, microsaccharoidal, calcareous, intercalated with anhydrite, streaked white and pale yellow-brown from 7595 to 7600 feet

Anhydrite, white and pale-yellow-brown streaked ; intercalated with light-olive gray microsaccharoidal calcareous dolomite

Dolomite, light-olive-gray, microsaccharoidal calcareous; intercalated with finely crystalline anhydrite, streaked white and pale yellow-brown from 7605 to 7610 feet

Limestone, light-gray and brownishgray, cryptocrystalline

Limestone, yellowish-gray, cryptocrystalline

Dolomite, yellowish-gray, microsaccharoidal, calca reous

Limestone, dark-brownish-gray, microcrystalline, dolomitic; interbedded with dark-brownish-gray microsaccharoidal calcareous dolomite from $\mathbf{7 6 6 5}$ to 7675 feet

Limestone, brownish-gray, microcrystalline, dolomitic; interbedded with brownish-gray microsaccharoidal calcareous dolomite

Limestone, yellowish-gray, microcrystalline, dolomitic; interbedded with yellowish-gray microsaccharoidal calcareous dolomite; contains a trace of particles of pyrite, $1 / 2-1 \mathrm{~mm}$ in diameter, and some uniformly distributed microcavities about $1 / 4 \mathrm{~mm}$ in diameter from 7330 to 7333 feet

(Sample missing)

Dolomite, pale-yellowish-brown, finely crystalline to medium crystalline, with crystals well developed but not well consolidated; contains some microcavities, $1 / 2-4 \mathrm{~mm}$ in diameter.....

Dolomite, light-olive-gray, finely crystalline; contains sparse microcavities, $1 / 2-4 \mathrm{~mm}$ in diameter..............

( Sample missing) Same as from 7780 to 7825 feet (Sample missing)

Same as from $\mathbf{7 7 8 0}$ to $\mathbf{7 8 2 5}$ feet.-. Limestone, brownish-gray, microcrystalline: contains sparse microcavities, $1 / 2-4 \mathrm{~mm}$ in diameter, from 7845 to 7855 feet

Dolomite, yellowish-gray and grayishorange-pink, cryptocrystalline, argillaceous

Middle Devonian.

Elk Point formation (McGehee, 1952, p. 64) : Mudstone, pale-reddish-brown dolomitic; contains intercalations of white
Depth to Thick- bottom of $\begin{array}{lc}\text { ness } & \text { stratum } \\ \text { (feet) } & \text { (feet) }\end{array}$

Middle Devonian-Continued

Elk Point formation-Continued

finely crystalline gypsum from $\mathbf{7 8 9 0}$ to $\mathbf{7 8 9 5}$ feet. intercalations of white finely crystalline gypsum from 7890 to 7895 feet, intercalations of grayishred cryptocrystalline argillaceous dolomite from 7900 to 8100 feet, and sparse microcavities $1 / 8-2 \mathrm{~mm}$ in diameter from 7900 to 8100 feet......

Mudstone, pale-reddish-brown, dolomitic; contains some microcavities $1 / 8-4$ nim in diameter, and intercalations of grayish-red cryptocrystalline argillaceous dolomite from 8120 to 8140 feet. udstone, yellowish-gray, dolomitic; ininterbedded with white and yellowish-gray finely crystalline gypsum; contains a few fragments of colorless silica and white chert in irregular shapes, some of which look like silicified fossil fragments, the others like silicified concretionary material_....-

Mudstone, olive-gray and yellowishgray, dolomitic; interbedded with yellowish-gray finely crystalline gypsum and yellowish-gray microcrystalline dolomite ; contains some fragments of colorless silica and white chert that are the same as those from 8140 to 8210 feet; samples missing from 8235 to 8240 feet

$210 \quad 8,100$

$40 \quad 8,140$

Gypsum, white, finely crystalline; contains microstreaks of pale-yellowishbrown finely crystalline dolomite

Dolomite, pale-yellowish-brown microsaccharoidal; intercalated with white finely crystalline gypsum

Dolomite, yellowish-gray, microsaccharoidal -

Limestone, light-yellowish-gray and olive-gray, microcrystalline; contains some micropartings of dark-gray shale from 8335 to 8360 feet, and from 8375 to 8435 feet. Total depth, 8435 feet

DES LACS WESTERN OIL COMPANY, BLUM WELL 1

This well was drilled in Ward County, 2 miles northwest of Des Lacs in the NE1/4 sec. 9, T. $155 \mathrm{~N}$., R. $85 \mathrm{~W}$. It was abandoned in 1923 at a depth of 3,980 feet. The cuttings were originally studied and stratigraphic interpretations were made by $\mathrm{J}$. B. Reeside, Jr., and W. T. Thom. A generalized log by Simpson $(1929$, p. 252-253) was made from these interpretations. In 1951, the part of the section between the top of the hole and the top of the Pierre shale was further studied by W. A. Cobban of the Geological Survey. The following interpretations are a result of these studies. 
Measured section of Des Lacs Western, Blum well 1, in the SW1/4 sec. 4, T. 155 N., R. 85 W., Ward County

[Interpretation to top of Pierre shale by W. A. Cobban; interpretations from top of Pierre shale to bottom of hole by J. B. Reeside, Jr., and W. T. Thom]

Altitude at surface, 1985 feet.

Pleistocene.

Glacial drift:

(Sample missing)

Till (one sample)

Pulverized gray limestone boulde

Tertiary.

Fort Union formation.

Tongue River nember:

Siltstone, light-gray, calcareous; some lignite and brown ferruginous mudstone

Siltstone, pale-yellowish-brown, calcareous -

Siltstone, medium-light-gray

Siltstone, medium-light-gray ; contains comminuted plants.

Siltstone, medium- to dark-gray, carbonaceous, sandy

Sandstone, medium-light-gray, mediumgrained, massive, soft, friable

Siltstone, pale-yellowish-brown to lightolive-gray

Coal

Cannonball member and Ludlow member :

Mudstone, medium-olive-gray

Siltstone, light-olive-gray

Mudstone, medinm-gray

S a n d s t o n e, medium-light-gray, finegrained, massive

Mudstone, medium-dark-gray, carbonaceous ; contains some lignite

Upper Cretaceous.

Hell Creek formation :

Mudstone, medium-gray

Mudstone, medium-light-gray

Mudstone and medium-light-gray sandstone

Mudstone, medium-light-gray ; contains yellowish-brown clay ironstone

Siltstone, light-gray ; contains clay ironstone

Sandstone, light-gray, fine-grained, bentonitic, massive, soft

Siltstone, medium-light-gray ; contains much clay ironstone

(Sample missing)

Pierre shale:

Shale, light-gray; with calcareous layers _......

No cuttings; reported by driller as "limestone, with good show of oil."---

Shale, gray.

Limestone, light-gray, shaly; with fragments of fossils.

Shale, gray; with calcareous layers whitish clay in lower part

Shale, gray, rather calcareous
$5 \quad 1,905$

651,960

20

185
Upper Cretaceous-Continued

Pierre shale-Continued

Thickness Depth to bottom of

Shale and limestone, gray, calcareous. According to driller's report there is sandy shale and sandstone, showing 1 to 10 barrels of oil a day, between 2,300 and 2,310 feet, which may correspond to the gas sand of the gas field at Glendive, Mont

Shale, gray, calcareous; fragments of fossils at 2,650 feet

Limestone, gray, shaly, with Ostrea and Inoceramus

Limestone, whitish, shaly

Shale, gray, crumbly

Limestone, blue, with Inoceramus and ostrea congesta (probably corresponds to Eagle formation

Shale, dark, crumbly, calcareous. Blue limestone containing pyrite and fossils from 2,995 to 3,030 feet. Driller reports sandstone showing 1 to 10 barrels of oil a day from 3,040 to 3,043 feet (probably corresponds to Telegraph Creek formation of southern Montana)

Niobrara formation:

Limestone, blue, with Baculites, Inoceramns and ostrea

Dark-blue to black calcareous; shale and limestone; contains Ostrea congesta and abundant fragments of thickshelled Inoceramus

Benton shale:

Shale, dark, gummy, somewhat calcareous _-.....

Shale, dark-gray, fairly splintery ; contains fragments of fossils

Shale, dark, gummy. According to driller, limestone and limy shale from 3,460 to 3,560 feet

$76 \quad 3,476$

Shale, dark, hard, massive, fairly calcareous

Limestone, gray

Shale, dark, massive

Limestone, massive, gray

Shale and limestone, dark, hard; with Inoceramus.

Sand, quartz; may correspond to Muddy sand or Newcastle sandstone of Wyoming; called Dakota sandstone by

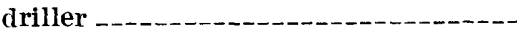

Shale, hard, dark, rather calcareous, with Inoceramus

\section{OTHER WELLS}

Stratigraphic correlations of three other wells in the Souris River area, in addition to the two already described, are shown in figure 3 . The correlations of the 


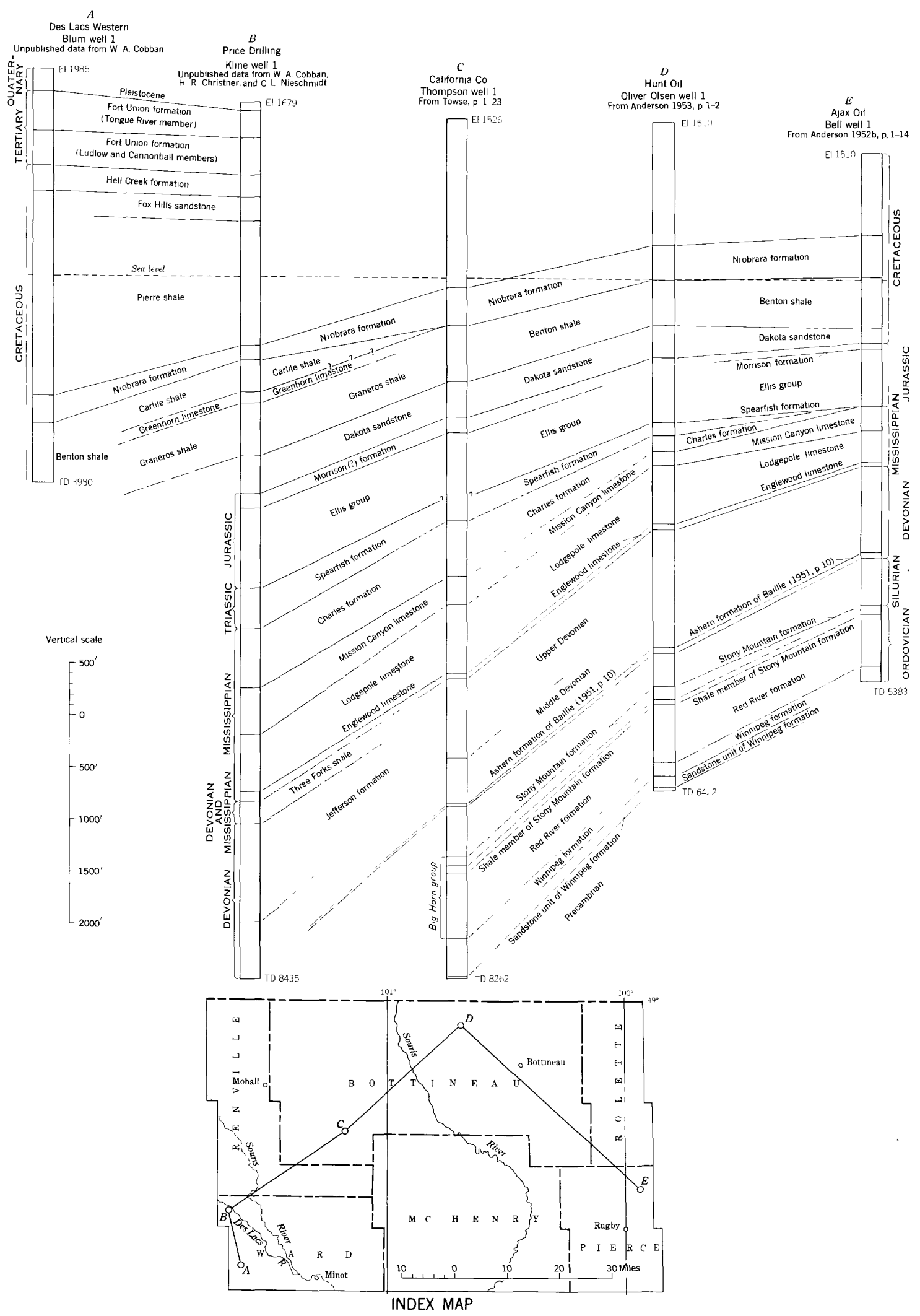

Figure 3.-Correlation of five wells in the Souris River area, North Dakota.

$4916240-60-2$ 
tineau County in the $\mathrm{SE} 1 / 4$ sec. 31 , T. 160 N., R. 81 W., are based on interpretations made by Towse (1952, p. 1-23). The correlations of the Oliver Olson well 1, drilled by the Hunt Oil Company in Bottineau County in the NW: $1 / 4$ sec. $18, T$ T. 176 N., R. 77 W., were made by Anderson (1953a, p. 1-2), as were also his interpretations (1952b, p. 1-14) on the Ajax Oil Co. Bell well 1, drilled in Pierce County in the NE1/4 sec. 28, T. 158 N., R. $72 \mathrm{~W}$. The Bell well 1 is situated a few miles east of the mapped area but is included to show the eastward continuation of the strata.

SUMMARY: ROCKS OF PRE-LATE CRETACEOUS AGE

Until recently, little was known of the older and deeper strata in North Dakota. Few wells had penetrated these strata, and it was necessary to extrapolate fragmentary data from nearby areas. Fieldwork was completed in the Souris River area before oil was discovered in the Nesson anticline in the western part of the State. The discovery caused a great increase in drilling in that area and in many other areas. As a result, knowledge of the deeper strata had increased considerably by 1952 .

Kline (1942, p. 336-341) has shown that Precambrian rocks are overlain directly by rocks of Cretaceous age in the Red River valley in eastern North Dakota. At Fargo, water-well data show that drift rests directly on granite at an altitude of about 650 feet. According to Laird (1941, p. 18-21), the Precambrian surface is 1,640 feet below sea level at Glenfield, in Foster County, and 1,679 feet below sea level (1951, sheet 1) in the Aanstad well 1, in Ramsey County. In the Souris River area, the Shoemaker well 1, in McHenry County in the SW1/4 sec. 3, T. 157 N., R. 78 W., penetrated Precambrian rocks at a depth of 7,198 feet (Anderson, 1953a, p. 1-15), or 5,718 feet below sea level. The M. O. Lee well, in Ward County in section 24, T. 156 N., R. 85 W., bottomed in the Winnipeg sand of Ordovician age at a depth of 10,134 feet, or 8,313 feet below sea level (Anderson, 1953b, p. 1-17). Presumably, Precambrian rocks are a couple of hundred feet deeper. Precambrian rocks lie even deeper to the west and are believed to reach a maximum depth below sea level in McKenzie and Dunn Counties, in the western part of the State (Laird, 1951, sheet 1).

Paleozoic rocks wedge out toward the eastern part of the State and unconformities exist (Laird, 1952c, p. 8-9). One of the most important unconformities, especially for oil production, is that of the Triassic and Jurassic, which overlaps beds of all ages from Permian to Ordovician and possibly older. Devonian strata are believed to rest unconformably on beds of
Silurian and Ordovician age. These relations are shown by Laird (1952c, figs. 2-11).

Cretaceous strata also pinch out toward the east, although basal strata are present in most places except in the southeast corner of the State. Pierre shale is the surface bedrock over a wide belt in the eastern part of the State.

\section{UPPER CRETACEOUS ROCKS}

PIERRE SHALE (NOT EXPOSED)

NAME, LOCATION, AND AREAL EXTENT

Pierre shale of Late Cretaceous age is nowhere exposed in the mapped area. It has been positively identified from fossils, however, as underlying surficial deposits in the Souris River valley one-fourth of a mile south of the International Boundary, in Bottineau County.

Outside of the mapped area, Pierre shale is exposed in the Souris River valley in Manitoba, $61 / 2$ miles north of the International Boundary. It is also exposed in Benson County, about 2 miles southwest of the town of Maddock in the SW1/4 sec. 36, T. 152 N., R. 70 $\mathrm{W}$., and locally farther to the east. Judging from these exposures and other data, Pierre shale is believed to form the uppermost bedrock in the eastern part of the Souris River area, as shown in figure 2. There are no available data, however, pertaining to these strata in the vicinity of Towner, and younger rocks may underlie that area. The known presence of Pierre shale in the Souris River valley in the northern part of Bottineau County and in the area to the southeast suggests, however, that it is present in the Towner area. Well data indicate that Pierre shale elsewhere underlies younger strata within the Souris River area.

The location of the contact between the Pierre shale and the Fox Hills formation is imperfectly known and in places may be several miles from the position shown on figure 2.

\section{THICKNESS}

The uneroded Pierre shale is 1,200 feet thick in the J. H. Kline well 1 and is interpreted to be 1,793 feet thick in the Des Lacs Western Oil Company well. In the Des Lacs Western Oil Company well, many samples are missing; the upper 200 feet or more may be Fox Hills sandstone, which was not identified here but was found in the J. H. Kline well 1. Anderson (1952a, p. 1-11), after studying cuttings from the Oliver Olson well 1 , about 15 miles east of Westhope, interpreted the base of the Pierre shale to be at a depth of about 1,170 feet. The top 70 feet or so of the hole was drilled in surficial deposits and the remaining 1,100 
feet in Pierre shale. It is doubtful that any great thickness of Pierre shale has been removed by erosion at this location. Anderson (1952b, p. 1-13) interpreted the base of the Pierre shale to be at a depth of 1,090 feet in the Ajax Oil Company Bell well 1 in Pierce County, in the NE1/4 sec. 28, T. 158 N., R. 72 W. The top 292 feet is drift and the remaining 798 feet is Pierre shale. How much shale has been removed by erosion, however, is not known.

The above scanty data suggest that the Pierre shale in the general area of Carpio thickens in a southerly direction. In the eastern part of the area shown in plate 2, about $800-1,100$ feet of Pierre shale is uneroded.

\section{STRATIGRAPHIC POSITION}

Pierre shale is probably everywhere underlain by the Niobrara formation. It is overlain by the Fox Hills sandstone except where the Fox Hill sandstone has been removed by erosion.

In the Souris River valley one-fourth mile south of the International Boundary in Bottineau County, Pierre shale underlies surficial deposits at a depth of 48 feet. The upper part of the surficial deposits consists of Recent alluvium, but that portion in contact with the bedrock is probably glacial outwash. Farther upstream, Pierre shale lies at a greater depth and is probably directly overlain by till, which is in contact with the bedrock almost everywhere else in the area. East of Upham in Bottineau County, SE $1 / 4$ sec. 5, T. 159 N., R. 76 W., a Bureau of Reclamation drill penetrated 37 feet of surficial deposits, of which the lower 19 feet was till, before encountering Pierre shale. Elsewhere to the southeast, south, and west, the surficial deposits overlying the Pierre shale are much thicker and exceed 150 feet in places. The 292 feet of surficial deposits directly overlying the Pierre shale encountered in the Ajax Company well 1, in Pierce County, is interpreted to consist of till, except for minor intercalated outwash.

\section{GRAIN SIZE, LITHOLOGIC COMPOSITION, AND BEDDING}

Because the formation is not exposed in the mapped area, its description is taken from nearby exposures and from well samples. Dark-gray to bluish-gray siliceous Pierre shale crops out in the Souris River valley in Manitoba, 6 miles north of the International Boundary near the town of Coulter. It generally breaks into splintery to rectangular pieces, each piece being moderately indurated. An exposure of Pierre shale southeast of the mapped area near Maddox is similar to the outcrop in Manitoba. Branch (1947, p. 12), described the Pierre shale of the Flora quadrangle in Benson County, east of the Souris River area, as follows:

In the few shallow surface exposures of the Pierre shale, it appeared as a blue-green, poorly indurated shale showing a pronounced rectangular cleavage causing it to weather into small blocks or sheets. Along the partings caused by this cleavage, weathering frequently produces a limonitic stain and a certain degree of induration as well. Small deposits of gypsum in the form of rosettes and small crystals are encountered. Near the surface, in addition to being discolored by limonitic stains, the shale tends to fade to a gray color.

In the J. H. Kline well 1, near Carpio, the formation consists of light-gray shale, some bentonite layers, and locally abundant brown ironstone. In the Des Lacs Western, Blum well 1, about 10 miles to the southeast considerably more calcareous layers were reported. Whether this difference in the logs of the two wells represents a difference in lithologic composition or a difference in interpretation is not known. It seems unlikely, however, that there would be a pronounced lithologic change in so short a distance.

\section{Fossirs}

Three samples from a hole drilled by the Bureau of Reclamation in the Souris River valley, one-fourth mile south of the International Boundary along the northern edge of sec. 31 , T. 164 N., R. 79 W., were examined by Steven K. Fox, Jr. The first sample consisted of a marine glauconitic shale from the top of bedrock at a depth of 48 feet; no fossils were found. In the second sample, marine shale taken from a depth of 66 feet, two species of Foraminifera were found, which indicated that the strata are Pierre shale. In a third sample, taken from a depth of 78 feet, three species of Foraminifera were found, which also indicated that the strata are Pierre shale.

In the J. H. Kline well 1, a few Foraminifera were found in the Pierre shale. Baculites sp. were found about 310 feet below the top of the formation. In the Des Lacs Western, Blum well 1, Ostrea congesta and Inoceramus were found about 500 feet below the top of the formation.

\section{ENGINEERING GEOLOGY}

Construction other than wells in the mapped area will probably not extend deep enough to penetrate the formation. The formation is easily penetrated in drilling; most beds are nearly impermeable.

\section{FOX HILLS SANDSTONE}

\section{NAME, IOCATION, AND AREAL EXTENT}

W. A. Cobban identified 245 feet of strata in the J. H. Kline well 1 (see $\log$ ) as Fox Hills sandstone of Late Cretaceous age. No Fox Hills sandstone was 
identified in the Des Lacs Western, Blum well 1 (see $\log$ ), but many samples were missing from the approximate interval at which this formation should occur and it is probable that Fox Hills sandstone is present. If the upper part of the section shown as Pierre shale is instead Fox Hills sandstone, the thickness of the Pierre shale would coincide more closely with its thickness in the J. H. Kline well only about 10 miles away. It is improbable, moreover, that 245 feet of Fox Hills strata would thin to extinction in the short distance between the Kline well and the Des Lacs well.

The only possible outcrop of Fox Hills sandstone within the Souris River area is on the south valley wall of the Souris River in McHenry County, one-fourth mile northwest of the town of Verendrye. Foraminifera identified by Steven K. Fox, Jr., prove that the upper part of the outcrop is the Cannonball member of the Fort Union formation. Minor channeling about 38 feet above the river between two friable sandstones tentatively marks the contact between the Cannonball member and the underlying Fox Hills sandstone. It is possible, however, that a few feet of the Hell Creek formation may lie between these two formations; this possibility is discussed under the heading "Hell Creek formation."

The Colgate member of the Fox Hills sandstone is identified tentatively in exposures southeast of the mapped area in a railroad cut in Pierce County about 7 miles east of the town of Anamoose, in the SW1/4 sec. 13 , T. 151 N., R. 74 W. If it is the Colgate member, it probably is the eastemmost extension of this member in this area. A few miles north of the International Boundary, along the lower part of the west flank of the Turtle Mountains, a similar white sandstone was mapped as the Boissevain formation by Wickenden (1945, map $713 \mathrm{~A})$; it is probably correlative with the Fox Hills sandstone. About 4 miles south of the International Boundary and about 3 miles northeast of Souris in the SE1/4 sec. 9, T. 163 N., R. 77 $\mathrm{W}$, several feet of tan sandstone, exposed in a stream bed, is also interpreted to be Fox Hills sandstone. W. A. Cobban identified the pelecypod Cymbophora sp. in a sample from this exposure. Upham (1895, p. 173) stated that sandstone crops out on Willow Creek and Ox Creek. These outcrops are believed to be east of Willow City in eastern Bottineau County and probably are Fox Hills sandstone, a supposition partly supported by the presence of 23 feet of sandstone penetrated in the water well of Willow City. White sediments in a water well at Westhope may also be Fox Hill sandstone. The areal extent of the Fox Hills sandstone shown on the bedrock map (fig. 2) is based on the above data and other evidence (see descriptions of the Pierre shale and the Cannonball member of the Fort Union formation). The position of the contacts may locally be several miles in error and can be refined only as more subsurface information becomes available.

\section{TOPOGRAPHY}

Present knowledge of the eroded surface of this formation is based almost entirely on data from a few wells and test holes. The total relief of the surface is probably less than 100 feet. A supposed preglacial channel (see pls. 2,14 ) nearly coincides with the area underlain by Fox Hills sandstone. If there is a preglacial channel, much of its floor and walls were probably cut into Fox Hills sandstone, and shallow tributary channels were probably also incised into these strata at and near their confluence with the main channel.

\section{THICKNESS}

Fox Hills sandstone, 235 feet thick, was penetrated in the J. H. Kline well 1 ; the top of these strata lies at an altitude of 765 feet. Beds of similar thickness probably underlie all younger strata to the west. Uneroded Fox Hills strata remaining in the eastern part of the mapped area, however, are probably considerably thinner. At least 35 feet of strata in McHenry County, near Verendrye, is believed to be Fox Hills sandstone. Seventy feet of strata, also believed to be Fox Hills sandstone, is exposed in a railroad cut about 7 miles east of the town of Anamoose, southeast of the Souris River area at an altitude of approximately 1,600 feet. The presence of outcrops of Pierre shale a few miles to the east indicates that the exposure in the railroad cut represents nearly the full thickness of uneroded Fox Hills sandstone in this area. In Bottineau County, near the International Boundary, the uneroded Fox Hills sandstone probably is less than 70 feet thick, judging from the nearness of exposed Pierre shale and from the supposed topography of the bedrock surface.

\section{STRATIGRAPHIC POSITION}

The formation is everywhere underlain by Pierre shale. From Carpio westward, it is assumed to be every where overlain by the Hell Creek formation. The Hell Creek formation, however, may thin to extinction somewhere between Carpio in Ward County and Verendrye in McHenry County, where the Cannonball member of the Fort Union formation is tentatively interpreted to rest directly on the Fox Hills sandstone.

The belt of the Fox Hills strata, which are directly overlain by surficial deposits, is confined almost wholly to the glacial Lake Souris area. A blanket of till probably separates glacial Lake Souris deposits from bedrock in this area. In the Verendrye area, valley fill 


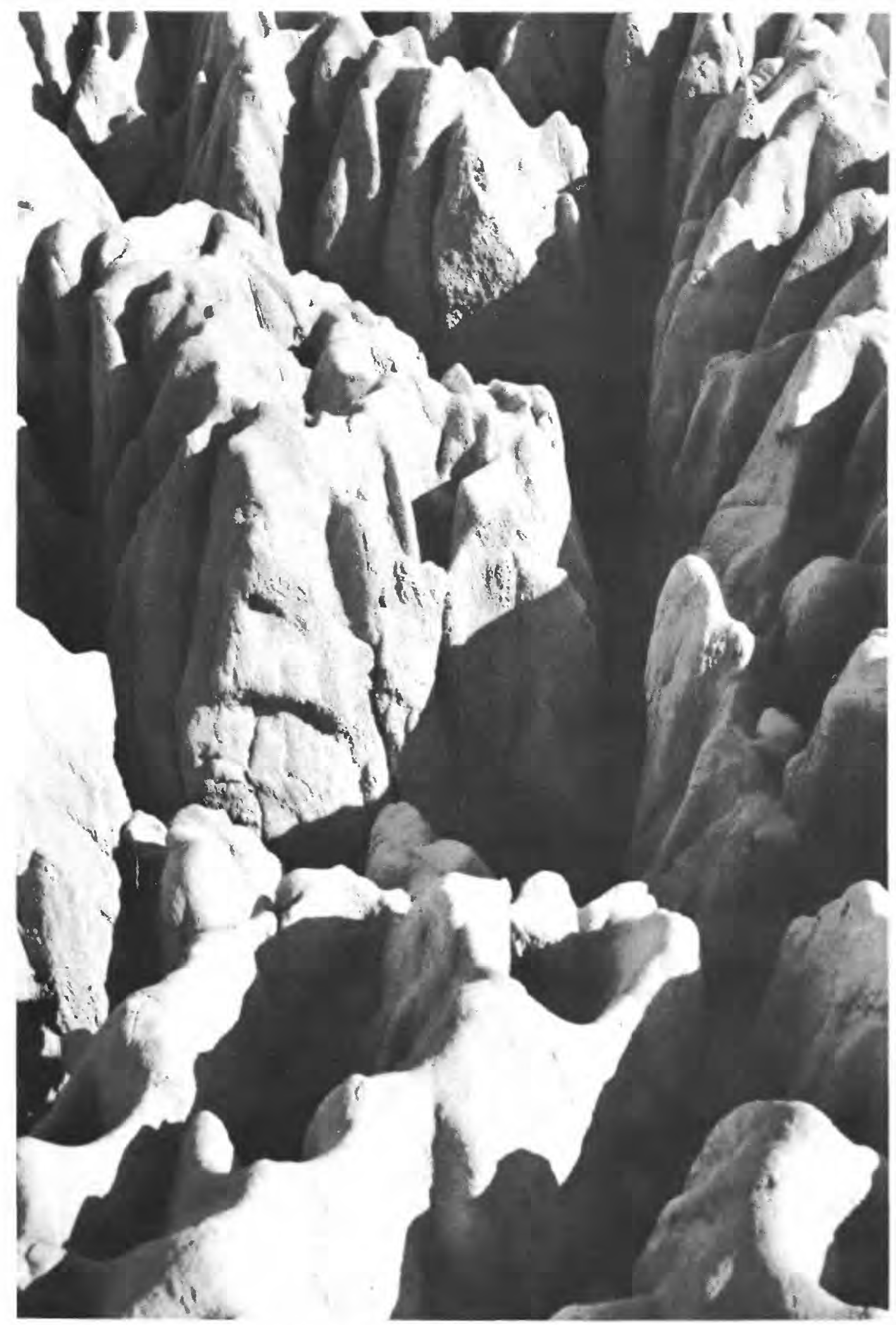

EXPOSURE OF THE COLGATE MEMBER OF FOX HILLS SANDSTONE EAST OF ANAMOOSE, N. DAK., IN THE SW1/4 SEC. 13, T. 151 N., R. 74 W., SHOWING MINIATURE BADLAND TOPOGRAPHY

Width of area shown is about 7 feet. 
probably overlies the formation for a few miles up and down the river valley.

\section{GRAIN SIZE, BEDDING, AND IITHOLOGIC COMPOSITION}

As previously mentioned, the lower 38 feet of the outcrop one-fourth mile northwest of Verendrye is tentatively interpreted to be Fox Hills sandstone. Diagnostic Foraminifera in the upper part of the outcrop indicate that part of the outcrop is the Cannonball member of the Fort Union formation. A measured section of the outcrop follows:

Measured section in outcrop one-fourth mile northwest of Verendrye

Paleocene.

Fort Union formation.

Cannonball member :

Shale, sandy, dark-gray, and sand beds, tan. (Foraminifera belonging to the Cannonball member have been identified from these beds by Steven K. Fox, Jr.)

(Covered)

Shale, sandy, dark-gray; and tan sand beds. Same as above; contains Foraminifera belonging to the Cannonball member.

Covered. Tentatively assigned to the Cannonball member but possibly belongs to the Hell Creek formation

Sandstone, semiconsolidated, orange-yellow, medium-grained, fairly massive. Flat discshaped sandstone concretions, 4-6 feet across, occur about 150 feet southwest of this measured section and appear to be 1-2 feet above the base of the orange-yellow standstone. The concretions are thinly bedded and break readily into thin fiat slabs. Tentatively assigned to the Cannonball member but possibly belongs to the Hell Creek formation.

Unconformity (?)

Cretaceous (?).

Fox Hills sandstone (?) :

Sandstone, semiconsolidated, gray, salt-andpepper appearance, medium-grained, some crossbedding; contains irregular pipe-shaped yellow concretions about 2 inches across which may be Halymenites. Contact between this sandstone and overlying sandstone is unconformable, with minor channeling of the lower sandstone

(Covered)

Sandstone, similar to that exposed above 5-foot covered interval

Lignitic bed consisting of lignite chips and macerated plant remains

(Covered)

Sandstone, consolidated, light-gray peppered with dark grains, medium-grained, some crossbedding. About midway in the interval is a lignitic and silicified horizon consisting chiefiy of macerated plant remains

Total thickness
Kline (1942, p. 356) apparently saw the flat disclike concretions at or near the base of the orange-yellow sandstone and interpreted the strata to be the Hell Creek formation. This possibility is discussed under the heading "Hell Creek formation."

In a second outcrop three-fourths mile upstream is exposed about 20 feet of tan sand and dark silty clay beds, containing numerous selenite crystals, which is underlain by about 20 feet of somber dark-gray sandy clay, rich in organic matter. Many concretions $11 / 2-4$ feet in diameter crop out at the base of the lower beds. They have been much fractured but the fractures have been filled with a yellow mineral. Impressions of leaves and stems of plants are fairly common in the concretionary mass. The concretions are about 20 feet above the Souris River, at nearly the same altitude as the flat disclike concretions near Verendrye, and it is likely that they occur at or slightly above the same stratigraphic position. If so, the Fox Hills sandstone may occupy the covered interval between these concretions and the bed of the Souris River.

The strata in the J. H. Kline well 1 that were interpreted by Cobban to be Fox Hills sandstone consist essentially of light-gray, fine- to medium-grained sandstone, soft medium-gray shale, and some soft shaly siltstone containing finely divided white mica.

The rock exposed in the railroad cut in Pierce County east of Anamoose and southeast of the Souris River area is tentatively assigned to be the Colgate member of the Fox Hills sandstone. The rock consists mostly of very friable white sandstone 70 feet thick eroded into a miniature badland of spires, caverns, and gullies. (See pl. 3.) Chocolate-brown carbonaceous shale in layers $1-2$ feet thick is scattered through the white sandstone and contains unidentifiable plant fragments. Charles Milton of the Geological Survey, who made a. study of a sample of this sandstone, described it as follows (written communication):

Except for extremely angular grains of quartz, which may approximate a fifth or so of the sandstone, it is practically impossible to estimate the percentages of the other minerals present. Much of these are indeterminate clayey substances; a little appears to have replaced feldspars; other is in the form of hexagonal plates, presumably after mica. No carbonates, sulfates, or ferromagnesian silicates (besides the altered mica) were seen. Nor are there any of the usual detritals, iron oxides, apatite, or such. A very few ragged zircons are present.

The sharply angular shape of the quartz grains seems to preclude the idea that it is a sediment that has had much waterborne transportation. The origin of such a sandstone is not clear; Dr. Clarence $\mathbf{S}$. Ross and others who have examined it do not think it is derived from volcanic ash.

This description agrees closely with that of the Colgate member in the vicinity of Glendive in eastern Montana (Brown, 1939, p. 239-240). 
FOSSILS

A few shell fragments and ostracodes were found in the J. H. Kline well 1. The exposure near Verendrye contains pipelike concretions, which may be Halymenites.

W. A. Cobban identified the marine pelecypod Tellina sp. collected by R. W. Brown and the writer from an exposure in sec. 19, T. 153 N., R. 72 W., in Pierce County. He also identified the marine pelecypod Cymbophora sp. collected from an outcrop about $21 / 2$ miles west of the west flank of the Turtle Mountains, in NW1/4 sec. 13, T. 163 N., R. 77 W., in Bottineau County.

The following Cretaceous Foraminifera were identified by Steven K. Fox, Jr., from a sample taken from an outcrop about 12 miles northeast of the town of Harvey, in the SE1/4 sec. 32, T. 152 N., R. 71 W.: Dentadina sp., Gyroidena sp., Nonion sp., Speropleclammina sp. Fox suggests (written communication) that these long-ranging Foraminifera belong to the upper Pierre. They were collected, however, from tan siltstone and fine sandstone whose lithologic character suggests Fox Hills sandstone. On the bedrock map, therefore, the outcrop is tentatively assigned to the Fox Hills sandstone rather than to the Pierre.

\section{ORIGIN AND HISTORY OF DEPOSIT}

Shoreline or near-shore deposition of most of the strata is suggested by macerated plants and other lignitic material in the sediments exposed near Verendrye. Also, according to Roland W. Brown (oral communication), the presence of Halymenites suggests marine shallow water deposition.

The origin of the white sandstone in the railroad cut in Pierce County is puzzling. The sharp angularity of the quartz grains precludes transportation by water more than a short distance. Likewise, the sediments do not appear to have been derived from volcanic ash.

If the interpretation is correct that the sandstone in the railroad cut is the Colgate member of the Fox Hills sandstone, the limits of this member are more than 200 miles farther northeast than heretofore known. Also, if the white sandstone a few miles north of the International Boundary on the lower part of the west flank of the Turtle Mountains is the Colgate member, its known limits are more than 100 miles farther north than the exposure in Pierce County.

Jensen (1951, p. 1453) has pointed out that the upper part of the Fox Hills sandstone in northeastern Montana is channeled. For the most part, the channels are filled with sandstone of the overlying Hell Creek formation; some channels contain pebble and cobble con- glomerate of an unknown source. How much erosion took place after deposition of the Fox Hills sandstone and before deposition of the Hell Creek formation in that area is not known with certainty. The Fox Hills sandstone in northeastern Montana ranges in thickness from 33 to 120 feet. If the interpretation is correct that the Fox Hills sandstone is 235 feet thick in the Kline well, considerable erosion is indicated in eastern Montana and western North Dakota, inasmuch as most Cretaceous strata thin to extinction between Montana and eastern North Dakota.

\section{ENGINEERING GEOIOGY}

The Fox Hills sandstone is fairly permeable. In some deep excavations, such as canal sites, its removal may require blasting. In most places, however, burial precludes its becoming a problem in most types of construction.

\section{HELL CREEK FORMATION}

NAME, LOCATION, AREAL EXTENT, AND THICKNESS

Hell Creek sandstone of Late Cretaceous age does not crop out in the mapped area except possibly in the exposure one-fourth of a mile northwest of Verendrye (described under heading "Fox Hills sandstone").

In the J. H. Kline well, sediments 205 feet thick, their top at an altitude of 969 feet, overlie the Fox Hills sandstone and are interpreted to be Hell Creek strata. About 10 miles to the southeast, Hell Creek strata 240 feet thick, their top at an altitude of 1,045 feet, were penetrated in the Des Lacs Western Blum 1 well. Westward, these strata probably continue beyond the limits of the mapped area. Somewhere east of the two wells, however, they thin to extinction, owing either to post-Cretaceous erosion or to nondeposition. If the Hell Creek formation was never deposited so far east, the Cannonball member of the Fort Union formation lies directly on the Fox Hills sandstone. Inasmuch as the Hell Creek formation has not been identified positively in this area, it is not shown on the map. If present but unrecognized, it probably is not more than 25 feet thick.

\section{GRAIN SIZE, BEDDING, AND LITHOLOGIC COMPOSITION}

The logs of the Kline and Des Lacs wells indicate that the formation consists of alternate beds of gray fine-grained sandstone, gray siltstone, mudstone, soft silty shale, and minor amounts of bentonite and yellowish-brown clay ironstone.

There is a possibility that the lower 17 feet of the section of the outcrop one-fourth mile northwest of Verendrye that is tentatively assigned to the Cannon- 
ball member of the Fort Union formation (see previous description of section) may be the Hell Creek formation. If so, the basal part of the formation at this locality is orange-yellow semiconsolidated mediumgrained sandstone containing flat disc-shaped sandstone concretions. The remainder of the section is covered. A second exposure about three-fourths mile upstream must also be Hell Creek strata. In this outcrop is exposed 20 feet of somber dark-gray sandy clay containing basal concretions, which underlies an equal thickness of supposed Cannonball strata.

\section{TERTIARY ROCKS}

All exposed bedrock in the Souris River area belongs to the Fort Union formation of Paleocene (Tertiary) age, except two exposures of possibly Cretaceous rocks near Verendrye. The marine Cannonball member of the Fort Union formation crops out in several places along the walls of the Souris River valley between Sawyer and Verendrye, and in a few places south of the river in McHenry County. The overlying continental Tongue River member of the Fort Union formation underlies much of the Souris River area (fig. 2 ). Several other nonmarine members are subdivisions of the Fort Union formation in the northern Great Plains, but only the Ludlow member has been recognized in some well samples in the Souris River area. The stratigraphic relations of these members to the Tongue River and Cannonball members and to adjoining stratigraphic units are shown in figure 4.

\section{CANNONBALL MEMBER OF THE FORT UNION FORMATION NAME AND LOCATION}

Prior to 1947, the northernmost known outcrop of the Cannonball member of the Fort Union formation was beside the Missouri River near Washburn, N. Dak. In July 1947, Brown and Lemke (1948, p. 624-625) discovered marine sediments about 1 mile east of Sawyer in the SW1/4 sec. 12, T. 153 N., R. 81 W. Sharks' teeth and other marine fossils, including diagnostic Foraminifera identified by J. A. Cushman and S. K. Fox, Jr., proved the sediments to be Cannonball strata. This discovery extended the known limits of the Cannonball sea 55 miles northward. In 1953, Fox (written communication) identified Foraminifera of Cannonball age in an exposure on the west flanks of the Turtle Mountains, about 25 miles east of Westhope in the NE $1 / 4$ sec. $17, T .163 \mathrm{~N}$., R. $76 \mathrm{~W}$. This discovery extended the known limits of these strata 60 miles northeastward and indicated that these sediments extend into Canada along the flanks of the Turtle Mountains. The recognition of Foraminifera of Cannonball age in cuttings from the Kline well near Carpio expanded the areal extent of the Camnonball sea an additional 35 miles to the northwest. The westernmost exposure of the Cannonball member in the Souris River area is along the eastern edge of Ward County, nearly 1 mile east of Sawyer. It is in a road cut where Highway 52 impinges against the wall of the Souris River valley at an altitude of 1,540 feet. This exposure evi-

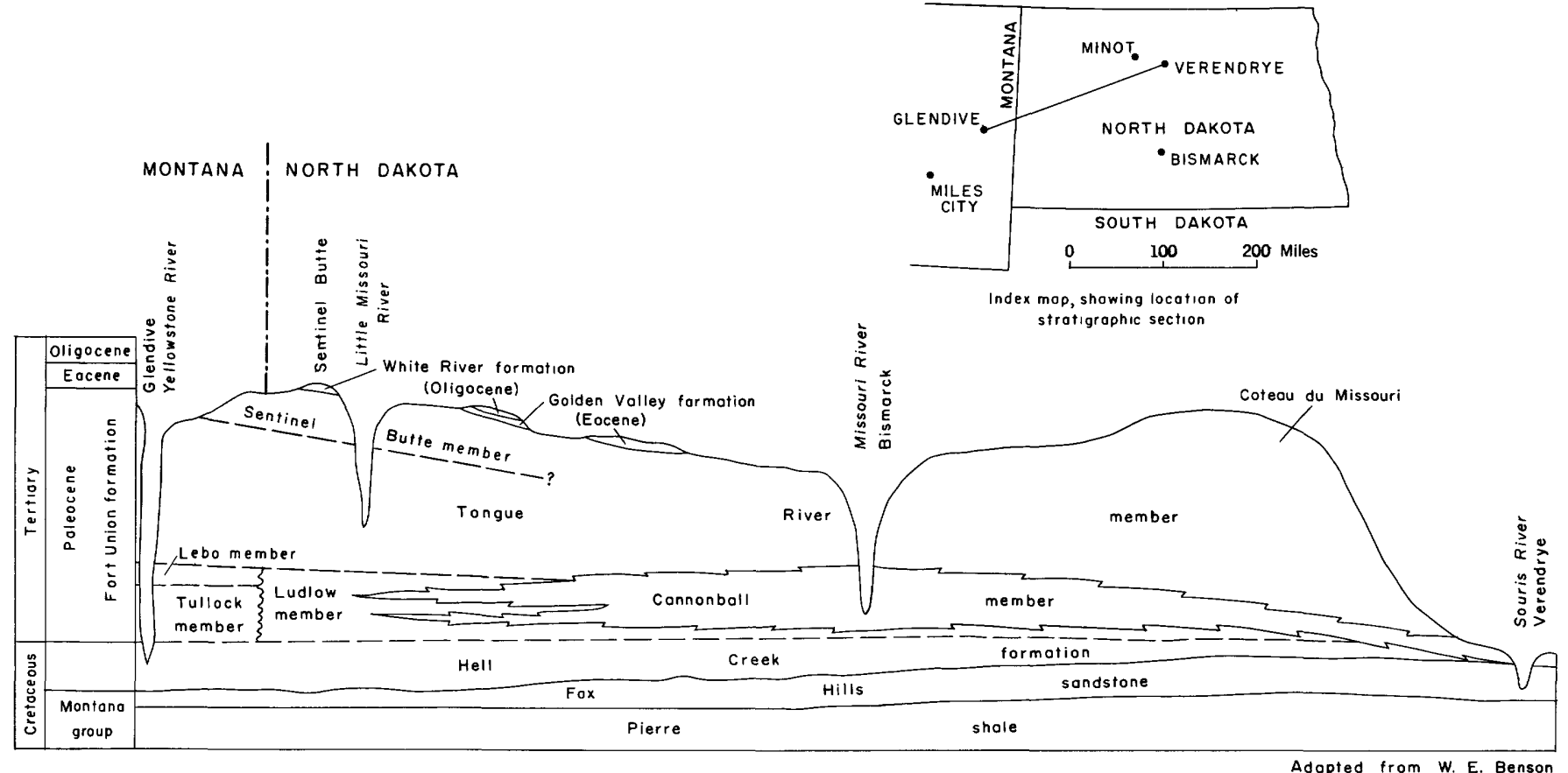

Frgure 4.-Stratigraphic section of Upper Cretaceous and Tertiary formations between Glendive, Mont., and Verendrye, N. Dak. This section is diagrammatic and generalized; it is not according to scale, elevation, thickness, or structure. 
dently represents the upper part of the member, because lignitic strata whose floral content suggests the Tongue River member of the Fort Union formation overlies the same nearly horizontal beds a few miles to the northwest. A bed of sandstone 15 feet thick, which contains casts of plant remains and crops out directly above the exposure, is believed to mark the base of the Tongue River member in that area.

Nearly all exposures of the Cannonball member are along the valley walls of the Souris River between Sawyer and Verendrye. A few other exposures are in or along the walls of diversion channels southeast of Velva; one such exposure, in the NW1/4 sec. 5, T. 152 N., R. $77 \mathrm{~W}$., is near the rim of a diversion channel and locally forms the core of a conspicuous linear ridge (see p. 62 ).

\section{AREAL EXTENT AND SIZE OF EXPOSURE}

The areal extent of the member in the mapped area is shown in figure 2 . Individual exposures are all less than 1,000 feet long and 40 feet high; most are only 50-150 feet long and 5-15 feet high. The road cut exposure near Sawyer in the SW1/4 sec. 12, T. $153 \mathrm{~N}$, R. $81 \mathrm{~W}$., where the Cannonball was first recognized in the area, is about 100 feet long and $3-5$ feet high; the soil profile constitutes much of the total thickness exposed.

Most exposures are in road cuts along the valley walls of the Souris River, in natural exposures where the river has meandered against the valley wall and cut away the overlying till, and in one tributary to the Souris River.

\section{THICKNESS}

The total thickness of the uneroded beds of the Cannonball member in the eastern part of the area is not known. A maximum observed thickness of 40 feet was measured in an undercut bank of the Souris River between Sawyer and Velva. The total thickness of the member probably is not much more in this area.

In the J. H. Kline well, 31/2 miles southeast of Carpio, 360 feet of strata were interpreted by Cobban (see $\log$ of well) to be Ludlow and Cannonball strata. However, it is not known how much of this section is Cannonball strata and how much is Ludlow. S. K. Fox, Jr., identified Foraminifera of Cannonball age in this well downward from a depth of 350 feet or an altitude of 1,329 feet. This is 211 feet lower than the indicated top of the member near Sawyer. It is possible that the top of the nember in the well may be higher, but no diagnostic fossils were present. This possibility seems unlikely, however, because a thin seam of lignite was penetrated at a depth between 245 and
300 feet or an altitude between 1,434 and 1,379 feet. The top of the Cannonball member, therefore, is probably somewhere below the coal bed. Also, a consolidated sandstone was penetrated immediately above the section containing the Foraminifera, and one of the few consolidated sandstones in this part of the stratigraphic section occurs at or near the base of the Tongue River member of the Fort Tnion formation. Thus it is likely that the sandstone is part of the overlying strata of the Tongue River member.

\section{STRATIGRAPHIC POSITION}

The Cannonball member is overlain stratigraphically by the Tongue River member of the Fort Union formation. Outside of the mapped area, as shown in figure 4, Cannonball strata intertongue with the Ludlow and Tongue River members of the Fort Union formation. Most of the evidence in the mapped area, however, does not point to such intertonguing. In all exposures where both Cannonball and Tongue River members are present, the Tongue River member overlies the Cannonball.

The Ludlow nember appears to underlie directly Cannonball strata in the Kline well 1 . In the Des Lacs well (see log) Cannonball and Ludlow strata have not been differentiated, but the presence of lignite near the bottom of the section indicates that the Ludlow member underlies the Cannonball member. In both wells Ludlow strata are underlain by about 200 feet of Hell Creek strata of Cretaceous age.

The exposure near Verendrye indicates that the Hell Creek formation may be lacking in the eastern part of the area and that Cannonball strata may rest directly on Fox Hills sandstone. If so, both the Hell Creek formation and the Ludlow member of the Fort Union formation pinch out between Verendrye and the Des Lacs well.

In the eastern part of the Souris River area, Cannonball strata are overlain unconformably by Pleistocene and by Recent deposits. This relation is discussed under the heading "Pleistocene deposits."

GRAIN SIZE, SHAPE, AND IITHOLOGIC COMPOSITION

The member consists chiefly of thin alternating beds of sand, silt, and sandy shale. The beds are commonly gray to tan. Oval carbonate-rich concretions, commonly $1-4$ feet in diameter, are exposed sporadically along the bedding planes in many exposures.

At the exposure one-fourth mile northwest of Verendrye, several flat disc-shaped sandstone concretions have weathered out slightly above an erosional contact between buff-colored sandstone and underlying gray sandstone. This erosional contact is believed to separate either the Cannonball marine strata or the Hell 
Creek formation from underlying beds tentatively interpreted to be Fox Hills sandstone. The concretions are $4-6$ feet in diameter and consist of thinly laminated sandstone that weathers into very thin plates.

In some exposures, especially southeast of the Souris River, a few beds about 1 foot thick consist of green unconsolidated sand. Selenite crystals, mostly less than one-half inch long, are common in some sand and shale beds exposed in southern McHenry County, in the $\mathrm{SE} 1 / 4$ sec. 15, T. $152 \mathrm{~N}$., R. $78 \mathrm{~W}$. The same beds also contain marcasite concretions, 1-2 inches in diameter, as well as plant remains and carbonaceous films. In an undercut bank of the Souris River in the western part of McHenry County, in the SW1/4 sec. 16, T. 153 N., R. $80 \mathrm{~W}$., an exposure of the Cannonball member 40 feet thick differs rather markedly in lithology from other exposures. This deposit is described on page 31 .

\section{BEDDING AND SORTING}

Most beds are an inch to a foot thick; nearly complete gradation exists between sandy and shaly beds.

\section{INDURATION, CEMENTATION, AND WEATHERING}

Other than concretions, most beds are very loosely consolidated and can be dug easily with a hand shovel. The green sand in particular is unconsolidated. The sandstone concretions are thinly laminated and weather into thin plates. Other more calcareous concretions are oval, fairly massive, and resistant.

\section{FOSSILS}

Shark teeth, worm casts, pelecypods, gastropods, ostracodes, and Foraminifera have been found. The shaly beds are especially fossiliferous. The following fauna were collected from an exposure near the top of the Cannonball member, 1 mile east of Sawyer in the SW1/4 sec. 12, T. 153 N., R. 81 W., at an altitude of 1,540 feet.

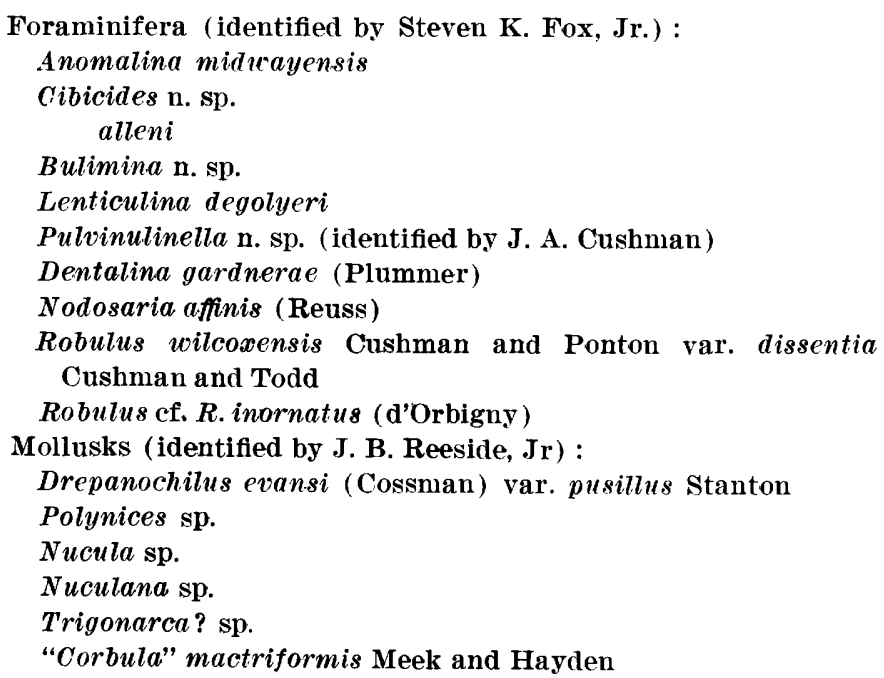

Neptunella gracilis (Stanton) newberryi (Meek and Hayden)

Fasciolaria (Mesorhytis) dakotensis Stanton Ostracodes (identified by Frederick M. Swain) : Brachycythere cf. B. interrasilis Alexander

Cytheridea cf. C. fornicata Alexander cf. C. ruginosa Alexander cf. C. multipunctata Alexander

Cythereis cf. C. prestwichiana Jones

Worm :

Serpula sp.

Shark teeth (identified by D. H. Dunkle) :

Odontaspis sp.

The Foraminifera Anomalina midwayensis and $\mathrm{Cibi}$ cides alleni, according to Fox (written communication), are restricted Midway (Paleocene) species on the Gulf Coast. He also stated that the dominant species, which is a good Cannonball marker, is Anomalina midwayensis.

John B. Reeside (communication to F. M. Swain) stated that all the ostracodes are characteristic of the Midway group of Texas. Cytheridea fornicata occurs only in the lower part of the Midway (Kincaid), and C. multipunctata only in the upper part of the Midway (Wills Point). The others range throughout.

Fossils found in an exposure of the Cannonball about $11 / 2$ miles east of Velva in the NE1/4 sec. $24, \mathrm{~T} .153 \mathrm{~N}$., R. $80 \mathrm{~W}$., at an altitude of about 1,520 feet include the following :

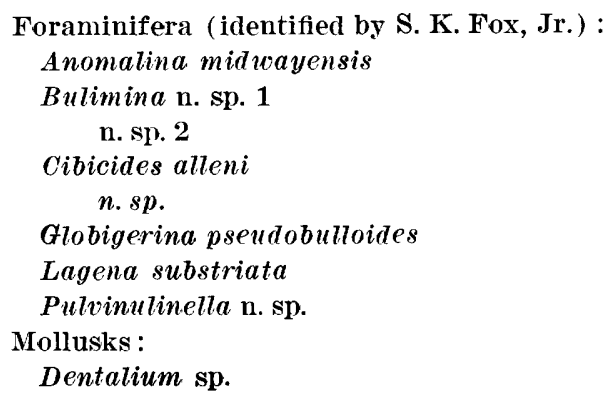

In addition to the Foraminifera already mentioned from the exposure a mile east of Sawyer, Globigerina pseudobulloides is a restricted Midway (Paleocene) species on the Gulf Coast.

The shale-rich section in the undercut bank of the Souris River in the SW1/4 sec. 16, T. 153 N., R. 80 W., at altitudes between 1,500 and 1,540 feet, contained the following Foraminifera identified by S. K. Fox, Jr.:
Alabamina miduayensis
Ammodiscus incertus
Anomalina midwayensis
Bulimina n. sp. 1
n. $\mathrm{sp} .2$
Ceratobulimina perplexa
cibicides alleni
praecursorius
Discorbis n. sp.
Epistomina elegans 
Haplophragmoides n. sp. 1

n. sp. 2

Lentioutina degolyeri

Nodosaria affinis

Pulvinutinella $\mathrm{n}$. sp.

Robulus midwayensis

In addition to the Foraminifera already mentioned, Ceratobulimina perplexa, Alabamina midwayensis, and Robulus midwayensis are restricted Midway (Paleocene) species on the Gulf Coast.

The following Foraminifera collected from the exposure one-fourth mile northwest of Verendrye in the SE1/4 sec. 30, T. 154 N., R. 78 W., at an altitude of about 1,525 feet, were identified by S. K. Fox, Jr. :

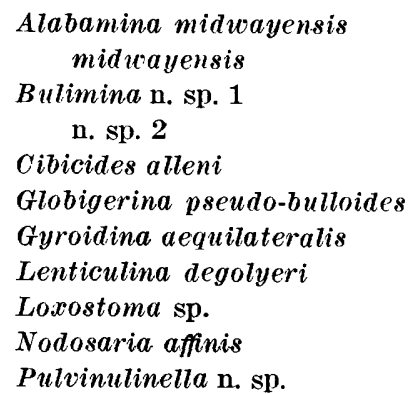

The strata in which these fossils were found may be at or near the base of the Cannonball member inasmuch as continental beds lie immediately below.

The following Foraminifera of Cannonball age were found northeast of the Souris River area on the west flank of the Turtle Mountains in the NE1/4 sec. 17, T. 163 N., R. 76 W., at an altitude of about 1,950 feet.

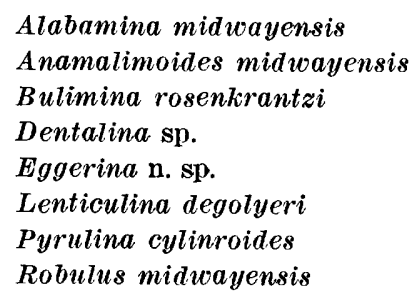

\section{ORIGIN AND TYPE OF DEPOSIT}

The 64 species of Foraminifera that Fox and Ross (1942) described from exposures in the south-central part of North Dakota show clear relationships to those of the Midway strata of the Gulf Coast. Fox, however, on identifying the Foraminifera from different exposures within the mapped area, stated (written communication) that these Foraminifera more nearly resembled the Arctic forms described from northern Europe than those of the Midway strata of the Gulf Coast. Therefore, although no marine fauna of Cannonball age has yet been found in the Canadian region, it is likely that the Cannonball sea invaded this area as an arm of the Arctic sea. The topographic position of the exposure of Cannonball strata on the west flank of the Turtle Mountains, a few miles south of the International Boundary, strongly suggests that Cannonball strata are present on the north flank of the Turtle Mountains in Canada. Similarly, these strata may be present in Canada north of Burke County where early Tertiary strata are known to occur.

No Cannonball strata have been positively identified as underlying the area between the exposures in southcentral North Dakota, which show a Gulf Coast relation, and those in the Souris River area, which show an Arctic connection. It seems likely, however, that the strata are continuous between the two areas and that the Cannonball sea had connections with both the Gulf of Mexico and the Arctic sea. This supposition is partly confirmed by an examination by Steven $\mathrm{K}$. Fox, Jr., of samples from the Hanson well 1, which was drilled, between these two areas, on the Coteau du Missouri in McLean County in NE1/4 sec. 10, T. $146 \mathrm{~N}$., R. $81 \mathrm{~W}$. Fox stated (written communication) that-

Samples from 130 to 1,000 feet are unfossiliferous and show no positive evidence for the Cannonball. Much of the material is lignitic and appears to be nonmarine. From 700 feet to 900 feet some of the samples contain glauconite and resemble the Cannonball. The glauconite sequences alternate with lignitic shale suggesting similarity with the alternating Ludlow lignitic beds and marine Cannonball west of the type Cannonball.

In the Souris River area, plant remains in some beds in southern McHenry County suggest deposition near shore. However, an overlying green sand bed 3 feet thick appears to be definitely marine. Likewise, beds exposed in the outcrop 40 feet thick near Velva, in SW1/4 sec. 16, T. 153 N., R. 80 W., all appear to be marine.

\section{SPECIAL IOCALITIES}

The bedrock in an exposure 40 feet thick in an undercut bank of the Souris River, in the SW1/4 sec. 16, T. 153 N., R. 80 W., is sufficiently different from bedrock in other typical exposures in the area to merit a detailed description. The following section is exposed:

Section of Cannonball member in bank of Souris River, in the SW1/4 sec. 16, T. 153 N., R. 80 W.

Shale, grayish-black, fissile: parting planes commonly about 1 inch thick. Some sandy layers__ Sand, green, medium-grained_-_-_-_-_ $\quad 0.5 \quad 21.0$ Limestone, dark (probably dolomitic) _-_-_- $\quad 0.5 \quad 21.5$ Sand, gray, fine-grained Shale, grayish-black, fissile; parting planes about 1 inch think

A sample taken between 20.5 and 22 feet from the top was studied by Marie L. Lindberg of the Geologi- 
cal Survey for heary minerals. About 2 percent of the sample contained grains having a specific gravity of more than 3. The percentages of these heavy minerals, according to grain size, are given in the table below :

Size analysis of heavy minerals ( sp gr $>3)$ in nontypical sample of bedrock of Cannonball member from section in bank of Souris River, in the $S W 1 / 4$ sec. $16, T .153 \mathrm{~N} ., R .80 \mathrm{~W}$.

\begin{tabular}{l|r|r|r}
\hline \multirow{2}{*}{ Screen-size minerals } & \multicolumn{3}{|r}{ Percent in indicated size range } \\
(mesh per inch)
\end{tabular}

ENGINEERING GEOLOGY

Nearly all the beds are unconsolidated and can be removed by hand shovel or power shovel. The sandy permeable beds have low plasticity and cohesion, whereas the sandy shale layers are more plastic and impermeable. Drainage in general is poor. Shallow cuts with slopes of less than $50^{\circ}$ show only local shumping, but deeper cuts and steeper slopes are susceptible to considerable sliding. Seepage of ground water along the more permeable sandy layers accelerates sliding.

An analysis, according to standards of the American Society for Testing Materials, conducted by L. C. Huff (Lemke, 1953) of strata consisting of particles of silt and clay size exposed in a roadcut near Velva, in the SW1/1 sec. 18, T. 153 N., R. 79 W., showed the following physical properties in relation to grain size:

Weighted frequency of grain size :

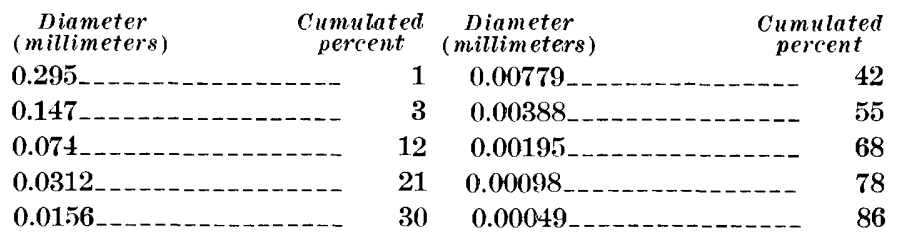

Specific gravity

Compaction $^{1}$ _._.

Porosity _-_._-_._-_ 49

Permeability _._._._._._._._._. 0.0001

Liquid limit____-_ 50

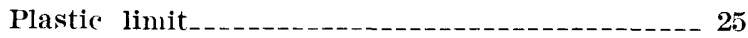

Plasticity index

1 Percent shortening of sample when pressure is increased from 8 pounds per square inch to 16 pounds per square inch.
Although this sample is probably typical of some beds of the formation, particles of sand size predominate in many beds. A more nearly representative sample of the formation, taken from sandy and shaly beds several inches thick that were exposed in a road cut near Sawyer, in the SE1/1 sec. 12, T. 153 N., R. 81 W., showed the following characteristics when tested by standard methods of American Society for Testing Materials :

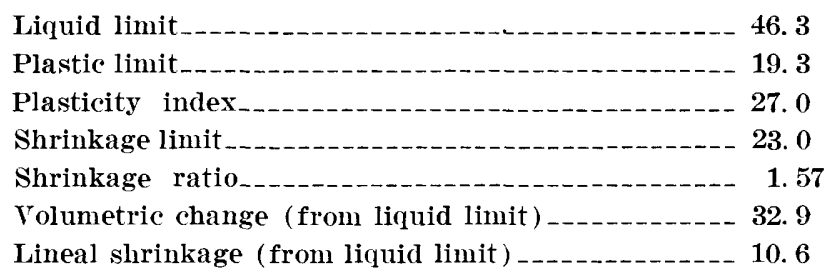

A sample of shale from the lower 5 feet of an exposure near Velva in the SW1/1 sec. 16, T. $153 \mathrm{~N} ., \mathrm{R}$. $80 \mathrm{~W}$. (see p. 31) had the following characteristics:

Liquid limit
Plastic limit
Plasticity index
Shrinkage limit
Shrinkage ratio
Volumetric change (from liquid limit)
Lineal shrinkage (from liquid limit)
TONGUE RIVER MEMBER OF THE FORT UNION
FORMATION
NAME AND LOCATION

Tongue River strata are exposed in small outcrops along the valley walls and main tributaries of the Des Lacs River and along the valley walls and tributaries of the Souris River from its confluence with the Des Lacs River downstream to the vicinity of Velva. Also, beds are exposed in a few places along the northeast escarpment of the Coteau du Missouri, and in lignite strip mines a few miles northeast of the escarpment. Nearly everywhere else the strata are concealed by glacial deposits.

\section{TOPOGRAPHY}

The eroded bedrock surface, as interpreted from exposures, test holes, and water-well data, is shown in plate 2. In general, the eroded surface of the Fort Union formation slopes slightly more steeply to the northeast than the present land surface. In places, however, the many local variations in relief are probably considerably greater than shown in plate 2 . Several channels, incised in Tongue River member of the Fort Union formation and wholly or partly filled with drift, traverse the area. These are discussed under the 


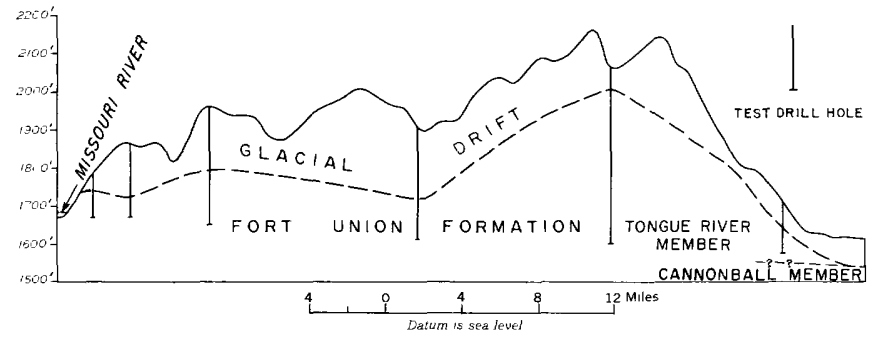

Figure 5.-Diagrammatic cross section of the bedrock underlying the Max moraine, along a line extending from the Missouri River near Garrison dam, in west-central North Dakota, to the northeast-facing escarpment of the Max moraine south of Velva. Modified from an unpublished profile by the U. S. Army Corps of Engineers.

heading "Glacial history." A relatively high plateau of Tongue River strata underlies much of the Max moraine (fig. 5). The northeast escarpment of this bedrock plateau coincides in many places with the northeast escarpment of the moraine.

\section{THICKNESS}

The uneroded beds of the Tongue River member range in thickness from several hundred feet in the western part of the area to a featheredge near the western shoreline of glacial Lake Souris in the eastern part of the Souris River area. The maximum thickness is not known. The highest outcrops in the area are in Burke County in sec. 15, T. 161 N., R. 91 W., at an altitude of about 2,050 feet. Two miles farther southeast along the scarp of the Coteau du Missouri, coal was mined from Tongue River strata at an altitude of about 2,250 feet. The highest outcrop in the southeastern part of the area is in McLean County, 4 miles west of Butte, in the $\mathrm{NE} 1 / 4$ sec. 11, T. 150 N., R. $79 \mathrm{~W}$., at an altitude of about 1,980 feet. The lowest exposed strata are along the valley walls of the Souris River and its tributaries in the vicinity of Sawyer and Velva, at an altitude of about 1,540 feet. If the beds are horizontal in the area between these two sets of exposures, about 440 feet of uneroded beds of the Tongue River member would underlie the exposure west of Butte. However, inasmuch as a gentle northeast dip is indicated in this area, the total thickness is probably less. Strata thicker than near Butte probably underlie parts of the Max moraine. For example, about 1 mile south of the exposure west of Butte, springs flow from the north flank of a high hill known as Dogden Butte. These springs are believed to issue from the contact between bedrock and till. If so, Dogden Butte has a core of bedrock whose top is at least 100 feet higher than the exposure 1 mile north and probably represents nearly 100 feet more of strata.

The $\log$ of the Des Lacs Western, Blum well 1 near Des Lacs indicates that 378 feet of Tongue River beds are present at that location as compared to a thickness of 255 feet in the Kline well, $31 / 2$ miles south of Carpio. The thickest single exposure of strata in the Souris River area is in Ward County, 1 mile northwest of Donnybrook in the NE1/4 sec. $16, T .158$ N., R. $87 \mathrm{~W}$., where 90 feet of strata crop out along the valley wall of the Souris River.

The thickest section of the Tongue River member appears to underlie the Max moraine, where its top forms a relatively high bedrock plateau (fig. 5). Northeast of the escarpment of this plateau, the Tongue River section becomes progressively thinner to the northeast, owing to greater erosion. The beds finally pinch out against the Cannonball member as shown in figure 2. In the Velva quadrangle, for example, only 10 to 40 feet of Tongue River strata overlie the Cannonball member. Similar conditions probably exist north of these exposures in the glacial Lake Souris area. Waterwell data in this area suggest that small thin outliers of Tongue River may exist northeast of the main body of strata. The largest outlier of these strata in this region is in the Turtle Mountains, outside of the Souris River area (fig. 2). The presence of coal beds in the Turtle Mountains north of the town of Dunseith strongly indicates that the strata belong to the Tongue River member. However, the fact that Cannonball beds have been identified well up on the west flank of the Turtle Mountains suggests that Tongue River strata probably are less than 100 feet thick in much of the Turtle Mountain area and may be considerably thinner or even absent in many places.

\section{STRATIGRAPHIC POSITION}

The general relations of the Tongue River member to other Tertiary strata are shown in figure $t$. The Tongue River member is the youngest bedrock in the mapped area. In exposures along the Souris River valley in the vicinity of Sawyer and Velva, the Tongue River member overlies the Cannonball member. The same stratigraphic relation probably exists to the north and perhaps also to the northwest as far as the vicinity of Mohall, in northeast Renville County. An undifferentiated section of the Ludlow and Cannonball members of the Fort Union formation underlies the Tongue River member in the Kline well 1 (see $\log$ of this well) and the Des Lacs Western, Blum well 1 (see log of well, p. 20), according to Cobban. Foraminifera of Cannonball age were identified at the top of the undifferentiated section in the Kline well, which shows that Cannonball strata directly underlie Tongue River strata. In the Des Lacs well, no identifiable Foraninifera were found at the top of the section, but the 
lithology of the section suggests that the upper part consists of Cannonball strata and the lower part of Ludlow. Whether Cannonball strata extend to the western edge of the mapped area is not known.

\section{GRAIN SIZE, SHAPE AND LITHOLOGIC COMPOSITION}

The Tongue River member consists chiefly of lightcolored alternating beds of sand, sandstone, siltstone, silty shale, and clay. Lignite constitutes less than 5 percent of the total section. Some sandstones contain ferruginous oval nodules or concretions ranging from less than 1 inch to 5 feet in length.

The general character of the member is shown by the following section measured in Ward County, in the S1/2 sec. 14, T. 159 N., R. 88 W. For convenience, most siltstone and clayey shale beds are termed shale.

Section of Tongue River member measured in Ward County, in $\mathrm{S}^{1} / 2 \mathrm{sec} .14, T .159 \mathrm{~N}$., R. $88 \mathrm{~W}$.

Top of section, altitude 1,890 feet.

Fort Union formation.

Tongue River member :

Thickness

Sand, gray-tan, shaly

(feet)

Lignite, slaked near top; and small pieces of silicified wood.

Shale, brown, sandy-

(Concealed)

Sand, gray-tan, silty

Lignite, slaked.

Shale, gray, sandy, silty

Shale, orange, sandy

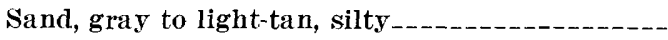

Sandstone; consists mostly of orange concretions -_...-...-

Shale, gray-blue, silty

Sand, tan, silty

Sand, gray-tan, silty ; contains numerous selenite crystals and abundant gastropod shells near

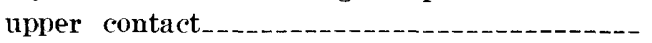

Shale, silty, black, carbonaceous____._-_._-_.

Shale, silty, gray-blue to brown

Lignite, partially slaked and dirty-_-_.......-

Shale, gray-brown; sandy near bottom

Sand, gray, silty ; indistinct yellow concretionary seams at 1-foot intervals. Top contact shows a synclinal fold, about 30 feet between limbs, trending about $\mathrm{N} .15^{\circ} \mathrm{W}$. and having an amplitude of about 3 feet...................

Sand and silty shale, proportions about equal, gray to light tan.

Sandstone, orange concretionary layer

Sand, gray to light tan, silty

Sandstone, gray, moderately consolidated....--

Sand, light-tan, slity

Sandstone; consists mostly of orange concretions

Sandstone, gray, moderately consolidated.

Sandstone: consists mostly of orange concretions

Sandstone, gray, moderately consolidated.

2. 0

1. 0

2. 5

13. 5
Fort Union formation-Continued

Tongue River nember-Continued

Sandstone, orange concretionary bed_.......-

Shale, sandy, gray-_._._.

Sandstone, orange, iron-rich, thinly crossbedded; moderately consolidated material grading along the strike into a tan-orange friable sandstone Sandstone, gray, moderately consolidated....-Sandstone, nearly all concretionary -_._-_._-_Sandstone, gray, moderately consolidated _...-Sandstone, grayish-white, noderaly consolidated. Separated by joints every 4 to 6 feet. Major joints strike about $\mathrm{N}$. $35 \mathrm{~W}$. and are nearly vertical. Irregular and indistinct contact with overlying bed. Generally massive but locally crossbedded

Sandstone, gray-white, moderately consolidated.-

Total

The $\log$ of a water well drilled in 1945 by the town of Bowbells in Burke County is as follows:

Log of municipal water well of Boubells, N. Dak., in the NE1/4 sec. $5, T .161$ N., R. $89 \mathrm{~W}$.

Surface altitude, 1,960 feet.

Total

Glacial drift:

Soil -...--

Clay, yellow....

Sand and gravel

Clay, hard, gray

Clay with stones.-

Fort Union formation :

Shale, clayey: and lignitic shale

Sandstone, gray

Shale, hard, blue

Lignite

Shale, soft; with thin lignite beds

Lignite

Shale, hard, brown

Shale, very hard, gray

Limestone, gray

Shale, hard, gray

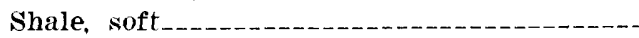

Shale, hard, gray ; with thin lignite beds...--

Shale, sandy, gray; and thin lignite beds with water

Lignite

Shale, very hard; with thin lignite beds_...-.

Shale, hard, gray

Shale, very hard : with soft layers

Shale. gray: and fine gray sandstone with small amount of water (cased off)

Limestone -..-_-_._-

Shale, gray: with thin beds of sandstone, fine, gray

Shale, very hard to hard.

Shale, sandy, soft

Sandstone, hard.

Sandstone. soft: with water and small amount of gas..

Shale, hard, gray
Thick(feess)

0.3

.5

1. 5

2.5

1. 5

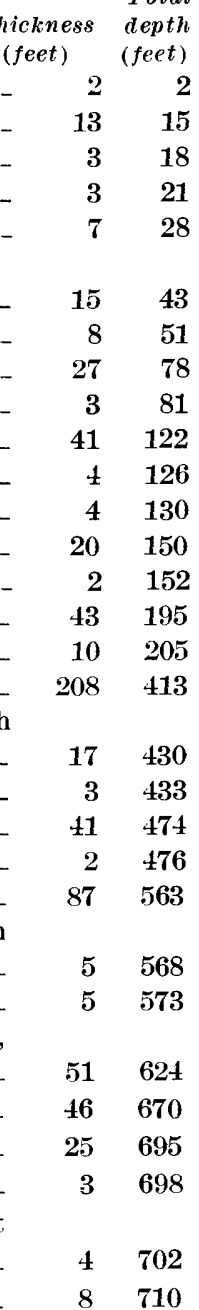


Many beds consist of material gradational in grain size between sandstone and shale. These beds are probably best designated as siltstone.

The term "shale" is used for many clay beds that are moderately compact and fissile. They are not as compact, however, as most shales found in other formations. They have about the same color range as the more plastic nonfissile clays, but coloration in hues of blue, green, and black is probably more intense. Selenite crystals are moderately abundant in some beds.

Nonfissile clay beds are far less common than shale beds; they are mostly in contact with lignite beds. The clay, in shades of gray, blue, green, and brown to nearly black, is very homogeneous. One of the thickest clay sections exposed is in a roadcut at Donnybrook in Ward County. Clay at this location differs from clay associated with coal beds in having a waxy texture and containing many plant impressions. It is described on page 36.

The lignite is dark brown to jet black and contains numerous well-preserved plant remains. Silicified wood is commonly associated with lignite beds in the Des Lacs River valley. It is discussed in detail in the section "Economic geology." Consolidated sandstone is limited chiefly to one or two beds near the base of the member. The largest and most conspicuous area of outcrop is 1-2 miles southwest of Velva in sections $28,29,32$, and 33 , T. 153 N., R. 80 W., where a bed of sandstone 10-15 feet thick crops out along the walls of two tributaries of the Souris River. This sandstone is cemented with calcite and breaks into joint blocks 2-6 feet across. It was used to a limited extent as a building stone in Velva.

A very small part of the total section is uncemented sand, of which quartz is the most abundant mineral and feldspar is probably second most abundant. According to grain-size analyses (by Marie L. Lindberg) of a sample from a road cut 5 miles northwest of Sawyer, along the valley wall of the Souris River in the SW1/4 sec. 30, T. 154 N., R. 81 W., 50 percent of the grains were larger than 150 mesh, 35 percent between 150 and 200 mesh, and 15 percent less than 200 mesh. Of the total sample, 0.16 percent of the grains had a specific gravity greater than 3 . Of this fraction, 4 percent was retained on the 150 -mesh sieve, 45 percent was retained on the 200 -mesh, and 51 percent passed the 200-mesh. Miss Lindberg calculated percentages of the minerals in the sample that have a specific gravity greater than three; they are arranged below according to grain size.
Size analysis of heavy minerals ( $s p \mathrm{gr}>3$ ) in sand from road cut northwest of Sawyer, N. Dak., in the SW1/4 sec. 30, T. 154 $N ., R .81 \mathrm{~W}$.

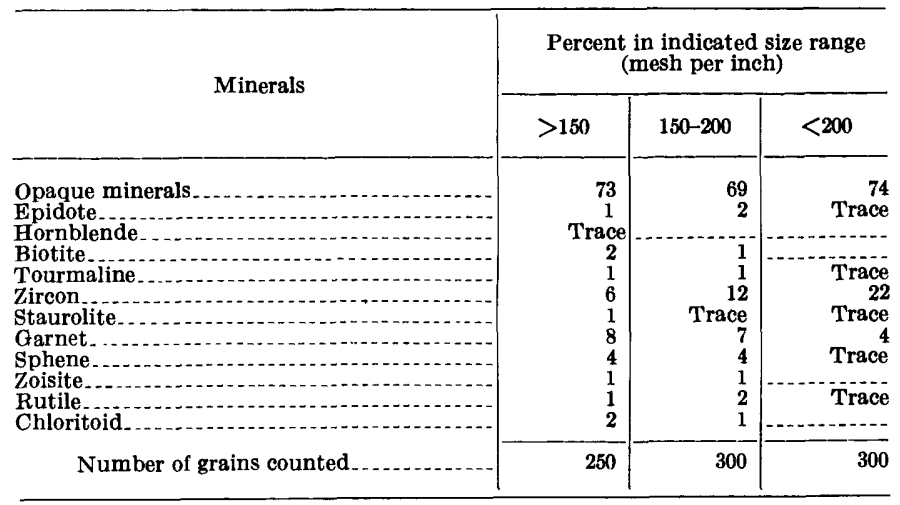

Sandstone 5-8 feet thick and similar to that near Velva crops out at an altitude of about 1,960 feet in a tributary in the southeast part of Ward County, in the SE $1 / 4$ sec. 26, T. 152 N., R. 82 W. Moderately consolidated sandstone also crops out in a few places south of Kenmare, along the valley walls of the Des Lacs River at an altitude of about 1,800 feet. It ranges in thickness from 10 to 15 feet, and along some bedding planes it contains many concretions. The color of the sandstone ranges from grayish white, through buff to orange where concretions are concentrated. Vertical joints 4-6 feet apart divide the sandstone into blocks.

A sample (analyzed by A. C. Vlisidis of the Geological Survey) from a sandy bed 5 miles northwest of Sawyer, in the SW1/4 sec. 30, T. 154 N., R. 81 W., contained 0.36 percent of total soluble salts, of which 0.10 percent was $\mathrm{CaO}, 0.03$ percent $\mathrm{MgO}, 0.03$ percent $\mathrm{Na}_{2} \mathrm{O}$, 0.01 percent $\mathrm{K}_{2} \mathrm{O}, 0.04$ percent $\mathrm{SO}_{3}$, and 0.002 percent Cl. An overlying shale bed contained 0.77 percent of total soluble salts, of which 0.10 percent was $\mathrm{CaO}, 0.08$ percent $\mathrm{MgO}, 0.10$ percent $\mathrm{Na}_{2} \mathrm{O}, 0.05$ percent $\mathrm{K}_{2} \mathrm{O}, 0.17$ percent $\mathrm{SO}_{3}$, and 0.002 percent $\mathrm{Cl}$.

\section{BEDDING AND SORTING}

Bedding ranges from distinct to indistinct. Most shale, clay, and lignite have sharply defined bedding whereas siltstone, sandstone, and sand generally have moderately to poorly defined bedding. Beds range in thickness from about 1 inch to more than 15 feet. Most, however, are 2-5 feet thick. Siltstone and sandstone beds are generally the thickest, and shale and lignite beds probably next thickest. Sand and clay beds are generally less than 3 feet thick.

Most of the sandstone is fairly massive, though locally it is crossbedded. The siltstone is less massive and is characterized by thinly laminated parting 
planes. The shale is likewise characterized by indistinct horizontal parting planes in addition to fissility. In places, the shale is cut by transverse fractures, commonly spaced 1-3 feet apart. Most sand beds are thinly laminated. In contrast, nearly all clay beds are massive.

\section{INDURATION, CEMENTATION, AND WEATHERING}

Sandstone is the only indurated rock in the section. Unweathered lignite beds are surprisingly resistant to erosion by water and abrasion by moving glacial ice. Because of their resistance to erosion, lignite beds commonly form well-developed benches on the steeper slopes. Their resistance to abrasion by glacial ice is shown by the fact that the contact between bedrock and till is commonly at the top of a lignite bed. Siltstone beds are weakly to moderately consolidated. They are less resistant to erosion than the sandstone beds but more resistant than the unconsolidated sand, clay, or shale beds. Rills on the faces of the siltstone outcrops commonly cause a fluted appearance. The shale is generally so much more erodible than the sandstone and siltstone that outcrops are conspicuous only on steep slopes where the shale is protected by more resistant overlying material. Probably the most resistant materials in the member, except for minor petrified wood associated with some lignite beds, are ferruginous oval nodules or concretions in some sandstone and siltstone beds.

Unweathered sandstone is predominantly light gray. Weathered sandstone is light tan to buff, and it is soft and crumbly, owing to dissolving of the calcareous cement. The buff to light-brown color of concretions is apparently caused by oxidation of the iron; in places, a fairly resistant indurated layer is formed by iron oxide that has impregnated definite horizons.

Lignite slakes upon oxidation and finally becomes sooty and lighter in color. Vertical contraction cracks, commonly spaced in a rectangular pattern about one foot in longest dimension, characterize unweathered lignite and afford easy passage for ground water. These cracks are enlarged by partial weathering of lignite. Shale beds show little color change attributable to weathering, but surface beds lose much of their fissility and resemble clay.

FossiLs

The most fossiliferous beds are found in the sand beds at the base of a road cut at Donnybrook in Ward County, in the SW1/4 sec. 1t, T. 158 N., R. 87 W. Few fossils other than leaves, tree trunks, and gastropods have been found elsewhere. The following specimens were collected by Roland W. Brown of the Geological
Survey and the writer from the exposure at Donnybrook:

Fossils from road cut at Donnybrook, N. Dak., in the SW1/4 sec. $14, T .158 N ., R .87 W$.

Flora (identified by Roland W. Brown) : Pods of plant, Cercidiphylum sp. (poplarlike) Platanus sp. (sycamore)

Ulmus sp. (elm)

Fauna.

Invertebrates.

Gastropods :

Campeloma nebrascensis (Meek and Hayden)

Fluminicola? cf. F. protea Yen

Pleurocera? sp.

Tiviparus sp.

Pelecypods :

Unio sp.

Vertebrates:

Mammal tooth, identified by Dr. C. L. Gazin of the U. S. National Museum as the trigonid portion of a lower tooth of an insectivore, apparently referable to the genus Aphronorus. The genus Aphronorus is one of the common forms in the Fort Union strata in the Crazy Mountains, Mont.

Skull and fragments of plates of trionychid turtle.

Vertebra of fish, identified by Dr. D. H. Dunkle of the U. S. National Museum as Styleomylodon lacus Russel.

Teeth of a crocodilian, identified by Dunkle as Allognathosuchus? sp.

\section{ORIGIN AND TYPE OF DEPOSIT}

The Tongue River member was deposited in an environment characterized by large continental swamps. Organic matter accumulating in these low areas was intercalated with sand, silt, and clay deposited by slow eastward-flowing streams that meandered on a broad flood plain. At least 500 feet of sediments, perhaps as much as 1,000 feet, accumulated in western North Dakota and eastern Montana; they thin eastward and feather out in central North Dakota.

\section{SPECIAL LOCALITIES}

A section exposed in a roadcut of U. S. Highway 52 at Donnybrook, in the SW1/1 sec. 14, T. 158 N., R. 87 W., described below, contains much more clay and sand than most exposures.

Measured section, roadcut of U.S. Highway 52 at Donnybrook. N. Dak, in the SW1/4 sec. 14. T. 158 N., R. $87 \mathrm{~W}$.

Top of bedrock, about 1.835 feet.

Pleistocene: $\quad$ Feet

Till, clay-rich, with cobbles____________________ 15

Paleocene. Fort Union formation, Tongue River member :

Clay, bluish-brown to yellow (oxidized), waxy, generally compact ; includes some sandy layers...-----

Lignite, oxidized and sooty-ar oxidized), waxy, homo-

Clay, bluish-brown to yellow (oxidized), waxy, homo-
geneous. 
Paleocene. Fort Union formation, Tongue River member-Continued

Lignite, oxidized and sooty

Sandstone, brown, calcareous (resembles dolomitic limestone) -

Sand, gray, fine, moderately consolidated near top...-

Sand, yellow-orange, fire, moderately consolidated (can barely be cut with a spade)

Sand, gray with some yellow layers, medium-grained, clean, unconsolidated, fossiliferous (see subheading "Fossils" for list of fossils found) -

Clay, bluish-brown to yellow (oxidized), homogeneous, compact. waxy, sectile; contains numerous brown impressions of flat-leafed reedlike plants $1 / 2-3 / 4$ inch wide and several inches long

Total_-
Feet

0.5

3. 0

2.5

4.5

22

\section{ENGINEERING GEOLOGY}

The strata possess a wide range of permeability. Clay and siltstone beds are nearly impervious. Likewise, shale is nearly impervious, though some ground water follows fracture planes. Sandstone generally is moderately permeable, owing largely to joints. Sand and lignite are highly permeable. Numerous vertical shrinkage cracks in the lignite beds afford easy passage for ground water; thus, lignite beds are the best bedrock aquifers. Most springs that feed the southwest tributaries of the Des Lacs River issue from either lignite or sand beds.

Stability of a slope depends on the composition and texture of the rocks that form it. Sandstone is the most stable of the rocks and in many outcrops it stands vertically. After considerable exposure, however, cementing material of the standstone is dissolved and the rock becomes soft, crumbling readily into more gentle slopes. In some places, sandstone separates into blocks along nearly vertical joint planes and moves downslope. Siltstone is second only to sandstone in slope stability and stands in steep slopes, though after prolonged exposure it is fluted with erosional rills. Wet shale stands in nearly vertical slopes but it slakes readily upon drying. Plastic clay beds are generally unstable. Sand beds slump and erode readily. Lignite beds stand in vertical slopes when fresh; upon drying, they slump along contraction cracks; upon further oxidation, they become sooty, disintegrate, and form talus slopes of small pieces.

Foundations resting on the Tongue River member show negligible settlement. The member generally forms a poor roadbed for unsurfaced roads; pitting and "washboarding" are common. Fills, however, are moderately strong if well compacted and drained. Poorly drained siltstones are subject to frost heaving.

Most beds can be cut only with difficulty with a hand shovel but are fairly easy to work with power tools. Most sandstone must be blasted, but some can be removed in blocks bounded by joint planes. Shale, clay, and sand are easily removed. Lignite can be removed with a power shovel in most places but locally must be blasted.

Sandstone is not suitable for riprap because of the calcareous material binding together the grains. It was used to a very limited extent as a building stone in Velva. Standard Tests of the American Society for Testing Materials performed by the rock-testing laboratory of the Public Roads Administration, showed the following properties of a sandstone taken near Velva:

Physical properties of sandstone near Telva, N. Dak., in sec. 28, T. 153 N., R. $80 \mathrm{~W}$.

Wear, Los Angeles abrasion test (grading A)

percent.

Toughness percent_- $\quad 48.4$

Weight per cubic foot_-_-_-_-_-_-_._-_pounds_-

Absorption -_-_-_-_-_-_-_-_-_-_-_-_percent_-

Bulk specific gravity (dry basis) -

Compressive strength of 1 by 1 inch cylinders lb. per sq in

Accelerated soundness test, weighted a verage ${ }^{1}$-_- $\quad 57.7$

Sodium sulphate solution (5 cycles). Loss weighted with respect to a uniform grading of naterial passing the $1 \frac{1 / 2}{2}$-inch sieve and retained on the No. 4 (0.185 in). The naterial lost all structural strength during the test.

The results of test data made by the Public Roads Administration on samples collected by Clifford A. Kaye from beds of the Tongue River member in Ward County, in the SW1/4 sec. 14, T. 158 N., R. 87 W., are shown below:

Physical properties of material from beds of Tongue River member in Ward County, in the sW1/4 sec. 14, T. 158 N., R. $87 \mathrm{~W}$.

[Tests by U.S. Bureau of Public Roads]

\begin{tabular}{|c|c|c|c|c|c|c|c|c|c|}
\hline Kind of material & $\begin{array}{l}\text { Liquid } \\
\text { limit }\end{array}$ & $\begin{array}{l}\text { Plastic } \\
\text { index }\end{array}$ & $\begin{array}{l}\text { Specific } \\
\text { gravity }\end{array}$ & $\begin{array}{l}\text { Natural } \\
\text { density } \\
\text { (dry in } \\
\text { lb per } \\
\text { cu ft) }\end{array}$ & $\begin{array}{l}\text { Coefficient } \\
\text { of perme- } \\
\text { ability (in } \\
\text { ft per day } \\
\text { loaded at } \\
2 \text { tons per } \\
\text { sq ft) }\end{array}$ & $\begin{array}{l}\text { Angle of } \\
\text { internal } \\
\text { friction } \\
\left({ }^{\circ} \mathrm{F}\right)^{1}\end{array}$ & $\begin{array}{l}\text { Cohesion } \\
\text { (1b per } \\
\text { sq ft) }\end{array}$ & $\begin{array}{l}\text { Public } \\
\text { Roads } \\
\text { Adminis- } \\
\text { tration } \\
\text { classifica- } \\
\text { tion }\end{array}$ & $\begin{array}{l}\text { Casagrande } \\
\text { classifica- } \\
\text { tion (modi- } \\
\text { fied by } \\
\text { Bureau of } \\
\text { Reclama- } \\
\text { tion) }\end{array}$ \\
\hline $\begin{array}{l}\text { Gray fatty clay } \\
\text { Gray and brown clayey siltt } \\
\text { Fine sand and silt } \\
\text { Fine sand, some silt. }\end{array}$ & $\begin{array}{l}74 \\
59 \\
41 \\
23\end{array}$ & $\begin{array}{l}50 \\
40 \\
22\end{array}$ & $\begin{array}{l}2.77 \\
2.72 \\
2.70 \\
2.73\end{array}$ & $\begin{array}{l}97 \\
96 \\
95 \\
95\end{array}$ & $\begin{array}{l}0.008 \\
.0001 \\
.0016 \\
.90\end{array}$ & $\begin{array}{l}21.0 \\
25.0 \\
26.5 \\
21.0\end{array}$ & $\begin{array}{l}750 \\
600 \\
400\end{array}$ & $\begin{array}{l}A-6 \\
A-6 \\
A-6 \\
A-2\end{array}$ & $\begin{array}{l}\mathrm{CH} \\
\mathrm{CL} \\
\mathrm{CL} \\
\mathrm{SP}\end{array}$ \\
\hline
\end{tabular}

${ }_{1}^{1}$ Determined by direct shear test; saturated undisturbed samples sheared at right angles to the bedding at normal stresses of $0.5,2,4$, and 8 tons per square foot. 


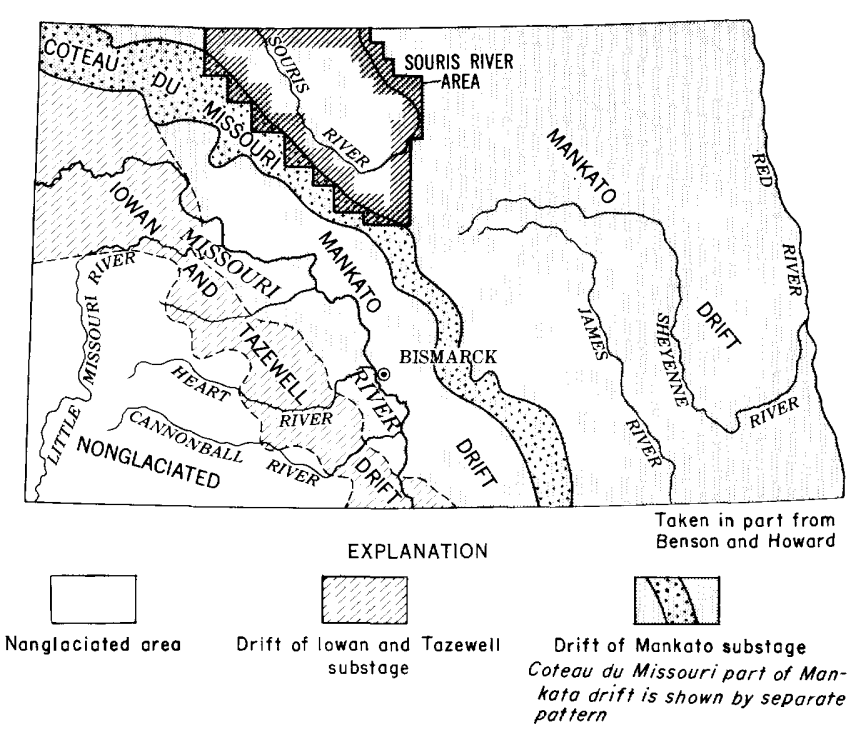

Figure 6. - Map showing drift borders in North Dakota.

\section{PLEISTOCENE DEPOSITS}

GLACIAL DRIFTS IN NORTH DAKOTA

As shown in figure 6, all of North Dakota except the southwest part was mantled with Pleistocene deposits. The line of demarcation between the glaciated and nonglaciated parts of North Dakota is based upon the work of Benson (1952) and Howard (1959). Till of the Iowan, Tazewell, and Mankato substages of the Wisconsin stage were recognized by Benson. Flint (1955, pl. 1) shows that deposits of all four substages of the Wisconsin stage are present in South Dakota but that only three are exposed at the South DakotaNorth Dakota line. Mankato substage drift overlaps Cary substage drift about 25 miles south of the State line. This overlap appears to continue into North Dakota. If so, any Cary drift that was deposited in North Dakota is probably everywhere buried by Mankato drift, which also mantles the Souris River area.

Benson (1952, p. 187) drew the outer limit of the Iowan drift border in North Dakota along the southwest limit of erratic boulders. Because of the apparent patchy distribution of the Tazewell drift, he was able to differentiate it in only a few places from the Iowan; hence, the two drifts are not differentiated in figure 6. The Mankato drift limits, although obscure in many places, are more clearly defined than the Iowan or Tazewell drift borders.

\section{POSSIBLE CRITERIA FOR DIFFERENTIATION OF WISCONSIN SUBSTAGES}

It is difficult to differentiate or trace till sheets in North Dakota with certainty. Differentiation of the drifts of the substages of the Wisconsin stage, by those working on the problem in North Dakota, Montana, and adjacent parts of Canada, has been based on several criteria. None of these criteria is unequivocal evidence in itself for differentiating substages, but several together provide a fairly good basis for differentiation. The criteria commonly considered are: (a) buried soils, (b) pebble orientation of the till, (c) composition of the pebbles in the till, (d) land forms such as moraines and drumlinoid features, (e) integration of drainage, (f) comparison of depth and degree of oxidation of tills, $(\mathrm{g})$ color differences of the tills, (h) stratified deposits separating the tills, (i) relations of glacial terrace deposits, outwash channels, and diversion channels with other deposits of known age, and (j) erosional unconformities between tills.

Of the above criteria $d, e, f, g, h, i$, and $j$, have been the most useful in the Souris River area. Reasons why other criteria were not especially helpful in the Souris River area are discussed below.

Buried soils.-A buried soil underlain and overlain by drift is unequivocal evidence of two drift sheets. However, the soil generally furnishes inconclusive evidence of the time interval that elapsed between the deposition of the two drift sheets. Flint (1955, p. 78) states that pedologists believe that under favorable conditions some soils develop during a period of possibly no more than a few hundred years. Very few buried soils have been found in North Dakota. None was found in the entire Souris River area. Benson $(1952$, p. 116) found a poorly developed soil separating two of the glacial valley fills in the Knife River valley.

Howard (1959) describes a well-developed buried soil that separates two Wisconsin substage tills a few miles west of Williston, N. Dak.

A thick humified zone does not necessarily indicate a well-developed soil profile; where the underlying material is fairly permeable, such as silt or sand, a thick humified zone can be developed in a relatively short time.

Pebble orientation.--Holmes (1941, p. 1299-1354) demonstrated that the long axes of pebbles in undisturbed till tend to be parallel to the direction of ice movement. Therefore, if each ice sheet advanced from a different direction, a study of the pebble orientations of the tills deposited by these ice sheets would afford a means of differentiating the tills. Many persons have made such studies. Simpson (1942, p. 35), Benson (1952, p. 109-110), and the writer in North Dakota, R. B. Colton (oral communication) in eastern Montana, and J. A. Elson (oral communication) in southern Manitoba have conducted such studies in the northern Great Plains and adjacent Lowland provinces. 
Several factors can influence the validity of results obtained from studies of the orientation of pebbles in till. (a) Local irregularities in the underlying bedrock may deflect the ice advance; hence, analyses should not be made along valley walls of rivers and tributaries, where, unfortunately, exposures are usually the best. Sites for analyses should be selected on flat upland areas where there is reason to believe that the underlying bedrock surface is also relatively flat. Even here, lobes of ice might be diverted in different directions by high areas many miles away. Colton (personal communication) has studied such areas in northeastern Montana. (b) Mud slides and partial reworking of the till by melt water can cause realinement of pebbles in ablation moraine that would be very misleading; hence, analyses should not be made in this kind of material. (c) Frost heaving, whether periglacial or seasonal, geologically ancient or recent, would disturb the orientation of the pebbles; therefore, the near-surface deposits are also to be avoided. Finally, (d) there is the interpretation of the results themselves. The usual procedure is to measure the long axis of every pebble found at each site, regardless of its shape. Generally, 100 or more pebbles at each site are measured. The writer believes that more accurate results are obtained by measuring only those pebbles that are at least twice as long in one direction as in any other direction and that the analyses of 25 such pebbles is more accurate than an analysis of 100 pebbles found at random. Even so, many analyses should be made in any area under study - a laborious and time-consuming procedure. Benson $(1952$, p. 110) found the results inconclusive. Likewise, the results in the Souris River area are not clear (see fig. 7 and discussion under heading "Ground moraine").

Pebble-lithology studies.-There is some promise for differentiating deposits of the several ice sheets in North Dakota by studying the lithology of the pebbles. This type of study is predicated upon the hypothesis that ice sheets, advancing from different epicenters, would incorporate into the drift pebbles of the same lithologic characteristics as the bedrock that the ice sheet had overridden and proportional in number to the areal extent of the overridden rock, provided that other factors-such as distance from source and resistance of rocks to abrasion-are equal. Howard (1959) found that the drift in an area in west-central North Dakota contained pebbles whose order of relative abundance differed rather markedly from that in surrounding drift areas, and he inferred that the drifts in these areas were deposited at a different time. Although there were no recognizable differences in the composition of the pebbles in these drifts, he was able, by using other criteria, to differentiate two separate drifts in the adjacent areas. One can conclude that the direction of advance of the ice sheets depositing these two drifts were nearly identical, and that under these conditions the pebble-lithology method has no value. Little difference was found in the lithologic character of the tillo in the Souris River area.

Land-form studies.-The orientation and configuration of some glacial features offer a partial key to the differentiation of drift sheets. The orientation of terminal moraines and end moraines, both large and small, help to indicate the direction of ice movement. Arcuate or lobate patterns formed by series of undrained depressions or small recessional ridges indicate direction of retreat of the ice front. Drumlinoid features in northeastern Montana, which have been studied by Colton (oral communication), indicate direction of ice advance. Where features that indicate direction of ice movement are truncated by other similar features, one might postulate two drift sheets, though individual lobes of one ice sheet might advance into an area from markedly different directions if they moved around a high area. By study of the orientation and configuration of the above-mentioned glacial features, the writer was able to separate deposits of two lobes of the Mankato ice in the Souris River area and vicinity (see pl. $15)$.

Integration of drainage.-The relative integration of drainage is commonly used in differentiating ice sheets. This criterion is of some help, especially in distinguishing stages. It can easily be misinterpreted in trying to distinguish intervals as small as substages. Differences in amount of local relief prior to deposition, differences in composition of deposits from one area to another, and differences in climate from one area to another are all factors that influence the amount of dissection. Drainage, except adjacent to stream valleys, is largely unintegrated in Mankato drift in North Dakota. In general, drainage is considerably more integrated in deposits of the earlier Wisconsin substages, but the topographic boundary in most places is too vague to be of much help in distinguishing the drift boundaries. Inasmuch as the mapped area had all been covered by Mankato ice, this criterion was of little help to the writer.

Depth and degree of oxidation.-Oxidation studies of the tills are helpful in some places in differentiating drift sheets but of little or no value in other places. Time is but one of several factors that influence such oxidation. Among the other factors are permeability of deposits, amount of precipitation from place to place, height of water table, and surface slopes of deposits where erosion partly or wholly keeps pace with rate 
of oxidation. Where oxidized till overlies unoxidized till, this criterion is of little value; but the presence of unoxidized till overlying oxidized till, especially where the permeability of each till is about the same, strongly indicates that the two are different. This last criterion is helpful in distinguishing two tills in the Souris River area.

Attempts have been made to use depth of leaching of calcium carbonate in glacial drifts as an aid in distinguishing different glaciations. But most of the factors that determine depth of oxidation also control depth of leaching of carbonates. In addition, biologic activity changes the character of surface deposits. Flint (1949a, p. 303) believes that the depth of calcium carbonate leaching can to some extent be considered critical where time differences correspond in stratigraphic value to stages, but that where time differences are of lesser value the inaccuracies created by variable factors make the results of doubtful reliability. Howard $(1947$, p. 1194-1195) also found that the depth of leaching in tills in western North Dakota could not be used to differentiate drift sheets. Therefore the writer did not attempt to use this criterion in the Souris River area.

Color differences.-These have been used as criteria for differentiating tills, but in the writer's opinion the method has little or no value in the northern Great Plains. In almost all places examined in this region, the differences in color are due merely to differences in degree of oxidation. The unoxidized till is generally bluish gray, whereas the oxidized till is light-gray to buff. Not uncommonly the contact is remarkably sharp, and it is difficult to conceive that the differences in color are due to differences in oxidation alone. It is more understandable, perhaps, when they are compared to color differences between $\mathrm{A}$ and $\mathrm{B}$ horizons of many soil profiles in the area, where commonly A horizon is nearly black, generally in sharp contact with $\mathrm{B}$ horizon, which is brown. In the soil, differences in color represent differences in mineral composition due entirely to chemical weathering processes. In some places, oxidation continues downward into the till, in which vertical contraction cracks are rimmed with gray-buff till where oxidizing solutions had free access; farther back laterally the till is bluish gray. Commonly, oxidation extends laterally along more permeable zones until it intersects vertical contraction cracks, whence again it extends inward toward the unoxidized central part until the center is completely enveloped by oxidized till. The center then resembles a piece of unoxidized till that has become incorporated in oxidized till.
Stratified deposits separating tills.-Another criterion that has been used to tell drift sheets apart is the presence of sheets of stratified deposits that separate tills. Judgment by this criterion alone is hazardous. If the stratified deposits can be traced under the overlying till so that relation to other deposits of known age can be determined, or in other ways correlated with such deposits, the method can be used to good advantage. Benson (1952, p. 114-136) used this method to correlate valley fills in the Knife River valley. However, where single exposures of stratified material are found lying between tills, there is no way of determining whether the stratified material represents a nonglacial phase or whether it represents merely stratified deposits intercalated in one till. This criterion was used in conjunction with others in differentiating Mankato till from older till in the Souris River area.

Relation of glacial terrace deposits, outwash channel deposits, diversion channel deposits, and simitar deposits to other deposits of known age.-Terrace deposits and outwash channel deposits can usually be traced headward to their sources; in places they head in a moraine, and a relationship is thus established. Diversion channel deposits may be correlated with glacial lake deposits many miles away into which the meltwater drained; the age of the lake deposits may be established by criteria from another area. In this manner, it has been possible to correlate glacial Lake Souris and its related deposits with glacial Lake Agassiz because of a diversion channel that connected the two lakes. Leverett (1932, map) determined the age of glacial Lake Agassiz deposits from his studies in that area, and on that basis it is possible to determine the age of the deposits in the Souris River area.

Erosional unconformities.-The presence of erosional unconformities between tills suggests but does not prove the existence of two different glaciations. Where unconformities extend over a wide area, two periods of glaciation are probable. Boulder pavements at the contact, suggestive of considerable erosion, help confirm the belief. This criterion was used in differentiating the Mankato till from an older till in the Souris River area. But better evidence is the presence of a welldeveloped soil profile separating the two tills. Local unconformities can be attributed to short-lived but intensive erosion of the till by glacial melt water during minor pulsations of the ice edge.

Two methods, used elsewhere in differentiating drift sheets, which have been little used in North Dakota, are pollen analysis and carbon-14 determinations. Pollen analysis probably will be of value in dating some of the glacial lake deposits. In the Souris River area, how- 


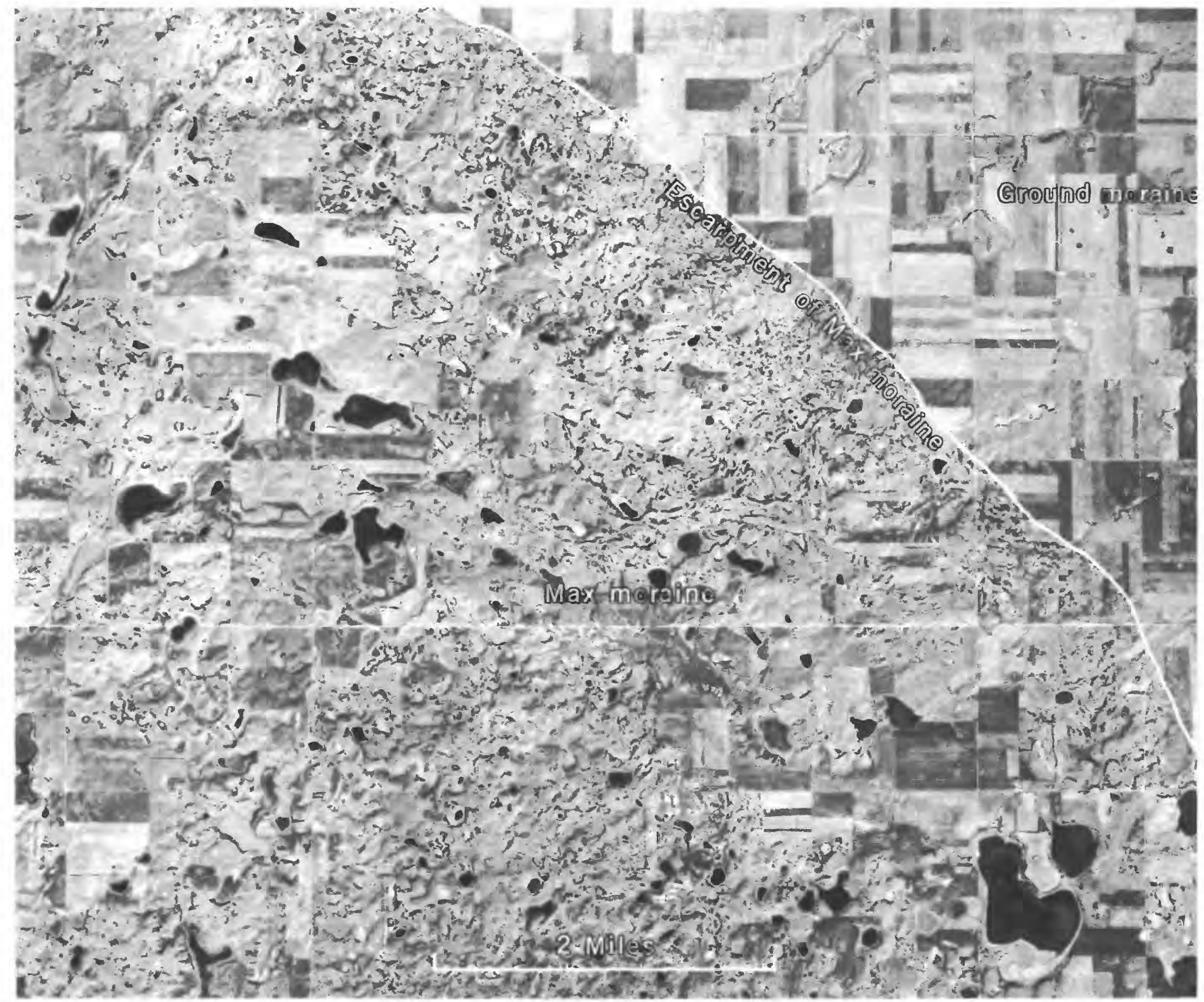

HIGH-ALTITUDE PHOTOGRAPH OF THE AREA SOUTHWEST OF KENMARE IN BURKE COUNTY, N. DAK.

Photograph shows topography of the Max moraine, the northeast escarpment of the Max moraine, and the contrasting relatively smooth topography of the ground-moraine plain to the northeast. 
ever, no deposits have been observed that appear especially suitable for pollen analysis. The surface deposits of glacial Lake Souris consist almost entirely of sand or silt. No peat deposits or lake clays containing pollen have been found, although, in places, lake clays are known to underlie the lake sand and silts and may contain pollen that could be used for analyses. Likewise, no material suitable for carbon-14 analysis has been found in the Souris River area.

\section{PLEISTOCENE DEPOSITS IN SOURIS RIVER AREA}

Surficial deposits mantle nearly the entire Souris River area. Most are of Pleistocene age and belong to the Wisconsin stage of glaciation. At least three Wisconsin ice sheets probably crossed the area, but the deposits of all except the last ice sheet are removed or were buried. Except for a few outcrops exposed by erosion along the valley of the Des Lacs River and possibly along the Souris River valley, all the exposed glacial deposits are assigned to the Mankato substage. These deposits consist of the Max moraine, ground moraine, overridden ice-contact deposits, linear-ridge deposits, diversion-channel deposits, river-terrace deposits, kames and eskers, end moraines in the Souris loop area, ice-marginal ontwash-channel deposits, glaciofluvial deposits undifferentiated as to origin, and deposits of glacial Lake Souris. All these deposits except part of the Max moraine were laid down in late Mankato time by the Souris River lobe, which advanced from the northwest. At about the same time the Leeds lobe advanced from the north and northeast, around the east flank of the Turtle Mountains, and laid down deposits to the east of the Souris River area (see pl. 15).

\section{MAX MORAINE}

NAME, LOCATION, AND AREAL EXTENT

According to Townsend and Jenke (.1951, p. 842$858)$, the Max moraine extends from the vicinity of Bismarck, N. Dak., several hundred miles northwestward into Canada. Throughout its length, the Max moraine is the surface deposit of the Coteau du Missouri. In the past, the moraine has been referred to variously as the Altamont moraine, Altamont(?) moraine, an end moraine, terminal moraine, so-called Altamont moraine, and Coteau du Missouri. It is also known locally as "The hills," or. "Coteau." Townsend and Jenke introduced the name Max moraine to avoid genetic comnotations and to leave room for future differentiation. The moraine is not continuous with the true Altamont moraine in South Dakota and the age relation of the two moraines is not known.

Only small parts of the moraine have been mapped in detail. The most extensive mapping along the proxi- mal edge is that in the Souris River area. Mapping was also done along the proximal edge by Townsend in the Columbus (1951, map), Noonan (1954a, map), Crosby (1954b, map), and Portal (1954c, map) quadrangles to the west. Howard (1959), Witkind (1958), Gott (1947, map), and Lindvall and Hansen (1947, map; 1948, map) mapped parts of the distal edge in western North Dakota and eastern Montana.

According to Bretz (1943, p. 31-52), the moraine continues northwestward 500 miles into Canada to a total length of more than 800 miles. Although the northeast and southwest margins of the deposit are roughly parallel, crenulations in the boundaries cause the width to range from less than 10 miles to more than 25 miles.

In the Souris River area, the Max moraine is the third largest mapped unit. It constitutes the southwestern part of the area.

\section{TOPOGRAPHY}

The Max moraine is a prominent, fairly even crested range of hills. In the extreme western part of the mapped area, the moraine locally reaches an altitude of about 2,500 feet, but most of the surface in the mapped area is at an altitude of about 2,300 feet. Southeastward from the point where it is 2,500 feet in altitude, the surface of the moraine decreases gradually in elevation, so that south of Minot the average altitude is about 2,150 feet and in the southeast part of the mapped area about 2,050 feet. Dogden Butte, in sec. 15, T. 150 N., R. 79 W., altitude 2,291 feet, is the highest point in the southeastern part of the mapped area. Most of the surface of this part of the moraine, however, ranges in altitude from 2,000 to 2,100 feet.

The proximal edge is marked generally by a fairly abrupt escarpment rising 200 to 300 feet above the ground-moraine plain to the northeast, but in some places the flat plains merge imperceptibly with the confusion of hills and depressions of the Max moraine. One of the most abrupt parts of the escarpment is along the west edge of the mapped area, where the change in elevation is about 200 feet in one-half mile (see pl. 4). South of Kenmare, by contrast, the gradation is so imperceptible that the boundary is arbitrarily. drawn within limits of about one-half mile.

Much of the altitude of the Max moraine is due to the greater height of bedrock under the moraine than under the adjacent plains (see description of Tongue River member). Although the general surface of the Max moraine exhibits a fairly even horizon, in detail it is highly irregular; local relief is generally 20-100 feet (see pl. 5A). 
The moraine is characterized by a mass of irregularly spaced small knobs, rounded hills, and ridges, separated by kettles, lakes, sloughs, and other undrained depressions; locally the surface is level. The larger undrained depressions are shown on the map by lake or swamp symbols. In places, closely spaced small hills and undrained depressions form the general pattern, whereas in other places the hills and depressions are larger and more widely spaced. Almost all the hills are rounded, and their gentle to moderately steep slopes show no evidence of erosion. The surface of the moraine completely lacks integrated drainage except along the edge of the escarpment.

The flanks and crest of Dogden Butte, in sec. 15, T. $150 \mathrm{~N}$., R. $79 \mathrm{~W}$., consist of a series of slightly arcuate ridges that are concave to the southeast. This is the only definite arcuate pattern on the Max moraine in the mapped area.

\section{THICKNESS}

The thickness of the moraine in the mapped area, inferred from drill-hole and well data, is generally between 100 and 200 feet. The fact that it is not as thick as its prominence suggests is because relatively high bedrock underlies the deposits (see pl. 2). In the Crosby quadrangle west of the Souris River area, Townsend and Jenke (1951, p. 852) found that the thickness of the Max moraine greatly exceeds 200 feet where drift fills the supposed pre-Pleistocene valley of the Yellowstone River. No major pre-Pleistocene buried valley is known to underlie the Max moraine in the Souris River area. Shallow buried channels are reflected by sags in the present surface. However, these channels are probably glacial melt-water channels formed prior to the last glaciation and were cut wholly in till or were incised generally less than 100 feet in bedrock. The trend of these supposed channels is shown by a distinctive symbol on plate 1 .

\section{STRATIGRAPHIC POSITION AND AGE}

The Max moraine in the Souris River area is everywhere underlain by the Tongue River member of the Fort Union formation. No younger deposits overlie the moraine except local thin alluvium and colluvium which have not been differentiated on plate 1 from the deposits of the moraine.

The drift that constitutes the moraine was deposited probably during several substages of the Wisconsin stage. Benson's work (1952, p. 184-194) indicates that at least three separate ice sheets advanced into the Knife River area. These ice sheets must also have covered the Souris River area. Their deposits must help make up the Max moraine, inasmuch as it is unlikely that they would have been entirely removed by succeeding glaciations or by erosion during the inter- glacial substages. Benson has recognized Iowan, Tazewell, and Mankato tills in the Knife River area and believes that Cary till is also present but is buried under the younger Mankato till. Till of each of these substages probably constitutes the Max moraine of the Souris River area. The surface and near-surface deposits are assigned tentatively to the Mankato substage. The till of the Souris River lobe, the most recent lobe of the Mankato substage in the area, is interpreted to extend in places onto the Coteau du Missouri and therefore, locally, constitutes part of the Max moraine (see pl. 15). However, the deposits of this lobe were not differentiated on plate 1 from the Max moraine because of like lithologic composition and because of the vague and indistinct margins of the lobe in this area.

\section{LITHOLOGIC COMPOSITION, SORTING, AND BEDDING}

The Max moraine consists predominantly of unstratified clayey till. In addition to the greater local relief, much more numerous undrained depressions, and generally higher elevation, it differs from the ground moraine by containing, in many places, more surface boulders. Townsend (oral communication), while mapping in an adjacent area to the west, found that the ground moraine was virtually free of boulders or boulder piles, whereas the Max moraine contained concentrations as great as 100 cubic yards per square mile.

The brown, buff, or drab yellow color of the till near the surface, as seen in many road cuts and building excavations, is due to oxidation of the clay and silt; where unoxidized, the till is gray to blue-gray. A similar buff color can be produced in the laboratory by placing blue-gray unoxidized till in a strong solution of hydrogen peroxide.

The dominant fine-textured part of the till consists essentially of an aggregate of quartz, feldspar, mica, calcite, gypsum, and clay minerals. The till is dense, compact, and hard when dry, and near the surface it has well-developed vertical joints. When wet, the clayey parts are plastic and unctuous. Sand-sized gypsum crystals, some as much as $3 \mathrm{~mm}$ long, are locally abundant. Evaporites are concentrated in a few undrained depressions but are much more abundant west of the Souris River area (Grossman, 1949, p. 1-66). Lignite fragments, blebs of limonite, and bits of petrified wood constitute minor amounts of the till.

The gravel and coarser fractions of the till consist of rocks of most of the common types. Limestone is the predominant rock in gravel size, and granite and gneiss are next most abundant. Granite and gneiss become more abundant in sizes coarser than gravel, and the larger boulders are predominantly of these rocks. 
Porphyry, schist, and basic igneous rocks constitute minor amounts of the till.

Seattered throughout the till are lenses and irregular masses of sand and gravel. Some of these stratified deposits constitute entire mounds and ridges; others are thin stringers a fraction of an inch thick and a few feet long. Some of this material is well stratified and well sorted, but most is poorly stratified. Some of the mounds and ridges are kames and eskers. Where it has been possible to delimit these features, they have been mapped separately. Where not so clearly defined or where very small, these deposits have been included with the Max moraine.

Lithologically, the ground moraine and the Max moraine are virtually alike. The boundary between the two units, therefore, is drawn chiefly on differences in topography.

\section{WEATHERING}

Caliche, a few inches to several feet thick, is concentrated in the C horizon of the soil that mantles the moraine. The caliche is mostly calcium carbonate. Generally, the caliche-rich horizon is loosely cemented, but where sand and gravel form the surface deposits, the caliche is commonly more firmly cemented.

\section{ORIGIN}

The buried bedrock plateau beneath the Max moraine was a partly but not completely effective barrier to the southward advance of each ice sheet. Different ice sheets overrode this barrier at their maximum, but minor lobes or pulsations were unable either to advance onto the bedrock high or to override it. Thus thick drift accumulated on the northeast flank and top of the bedrock plateau. The most recent lobe, which the writer has designated the Souris River lobe, adranced only locally onto the bedrock high in the southeastern part of the area.

The abundance of knobs, kettles, and similar features that characterize the surface of the moraine suggests wide bands of ice stagnation and mass wasting during deglaciation of the ice sheet that last covered the area. The abundance of boulders on the surface in comparison to the surface of the adjacent ground moraine, can perhaps be partly attributed to local removal of finegrained materials by melt-water and wind action. The ground moraine, because of its low relief, was less exposed to melt water and other subaerial action during deglaciation. There is little evidence of postglacial erosion; the drainage is almost completely unintegrated.

\section{ENGINEERING GEOLOGY}

The till of the Max moraine is essentially the same as that of ground moraine, and the reader is referred to the discussion "Engineering geology," under "Ground moraine," because more physical tests have been performed on the ground moraine than on the Max moraine. However, some characteristics of the Max moraine require special consideration.

Terrain and slopes.-The surface of the Max moraine is very irregular. Local relief is as much as 75 feet. The hills have gentle to steep slopes; but, although many of the slopes are too steep and irregular to be economically planted to crops, the tops of some hills and the bottoms of some valleys are nearly flat.

Drainage and permeability.-Most low areas are undrained, but surface drainage is good on hills. Subsurface drainage is slight to negligible because of the high clay content of the till.

Water table.--Depth to the water table is nearly as uneven as the height of the hills. Some undrained depressions contain intermittent lakes but others are most often dry. Perched water tables are probably common.

Boulders and cobbles.-Hard subangular cobbles, and boulders as much as 4 feet in longest dimension are scattered on and beneath the surface. These must be cleared for agricultural development and may be encountered in excavations.

Strbility and strength.-Natural slopes covered with sod appear to be stable. Where wet till is exposed in the few coulees or in manmade cuts, some slumping takes place; dry till stands nearly vertically. Vertical exposures of wet till slump or break away in masses of varying size along vertical prismatic joints. Gullies develop in some moderate to steep slopes where the sod cover has been destroyed. Foundation strength is high in properly compacted material on low to moderate slopes. Slumping and sliding may occur, however, if heavy structures are built on steep slopes. Frost heaving is slight to moderate.

Possible use and service records.-The deposits of the Max moraine have been used very little for construction. Unpaved roads are stable and are hard and smooth if graded soon after rains and allowed to dry before being used. Wet roads are nearly impassible because the clayey till is slippery, sticky, and incompetent. Graveled roads are satisfactory in most weather. Paved highways generally are built with broad shoulders and with cuts that have 1:1 slopes or less.

Frost penetration averages about 4 feet and reaches a maximum of $61 / 2$ feet. Foundations for buildings have been built entirely within the frost horizon without evidence of detrimental frost action.

Boulders and cobbles collected from fields have been used for fill, riprap on small dams, and rock and masonry structures. 


\section{GROUND MORAINE}

NAME AND LOCATION, AND AREAL EXTENT

Nearly flat-surfaced ground moraine extends northeastward from the Max moraine to the International Boundary and eastward to glacial Lake Souris. It is the most extensive unit in the mapped area. Although the ground moraine is nearly the same as the Max moraine in composition, its surface expression is markedly different. A prominent northeast-facing escarpment marks the boundary in most places between the two mapped units.

Deposits of till along the valley walls of the Des Lacs River, which are believed to be older than the ground moraine elsewhere, are included with the ground moraine because of the difficulty of differentiating the two deposits. Also included in this map unit is a thin veneer of sand and silt that locally mantles the ground moraine and is difficult to delimit. This material was probably deposited by the wind or by ephemeral glacial melt water, which spread out over the ground moraine before becoming confined to definite outwash channels. Deposits in kettles and other undrained depressions that dot the ground-moraine plain are not mapped separately from the ground moraine because of their generally small areal extent, although they are chiefly postglacial. Also small recessional moraines ("washboard" moraines) on the ground-moraine plain are generally so integral a part of the ground moraine that it has not been feasible to separate them.

\section{TOPOGRAPHY}

The surface of the ground moraine is a relatively flat plain that slopes gently downward to the northeast. Adjacent to the Max moraine, the ground-moraine surface is about 2,000 feet in altitude. The slope of the surface is considerably steeper near the Max moraine than some distance northeast of it. A strip of ground moraine 4-5 miles wide, adjacent and parallel to the Max moraine south of Minot, slopes northeastward about 80 feet per mile. Between this strip and the valley of the Souris River, the slope decreases to about 40 feet per mile. Northeast of the Souris River near Minot, the slope is about 30 feet per mile; it decreases to 10-20 feet per mile near Deering and becomes a nearly flat surface adjoining the area once covered by glacial Lake Souris. The chief modifying features of the plain are the Souris and Des Lacs Rivers and their tributaries. Ice-marginal outwash channels, diversion channels, end moraines in the Souris loop area, kames, eskers, and linear ridges also have been either incised in the ground-moraine plain or deposited on it.

As viewed from the air or from the Max moraine, the ground-moraine plain appears to be nearly flat and featureless (pl. 7). Although small, its local relief is fairly abrupt. Two general types of topography exist, with variations between.

One type of topography characterizes the area between the Max moraine and the Souris River valley between Carpio and Sawyer, in Ward County. It is a nearly flat surface modified only by round-to-elliptical shallow undrained depressions. Many of the depressions are flat-floored kettles 3-5 feet deep and 5001,000 feet across. A few large ones have steep-sided walls and are as much as 20 feet deep and more than half a mile in diameter. The usual number of depressions per square mile is from 25 to 50 . Nearly all contain ponds during the spring and early summer; some of the larger ones contain small lakes that become dry only during periods of prolonged drouth. Only the larger undrained depressions containing lakes or marshes are shown on the map.

The second type of topography, especially well developed in the triangular area between the Souris and the Des Lacs Rivers, is the more typical mound-andkettle surface. It characterizes the ground moraine in many places surrounding the Souris River area. The surface is very hummocky, although total relief is low ; from crest of mound to intervening trough is less than 20 feet generally and over wide areas is 5 to 10 feet. The depressions are generally smaller, less symmetrical, and much more numerous than the first type described. Some are rimmed by low indistinct circular ridges. Perhaps this type of topography characterizes ground moraine where there was a somewhat greater degree of mass wasting of the ice front during deglaciation than occurred in the areas exhibiting the first type of topography. Surface drainage is almost totally unintegrated. Only the larger undrained depressions are shown on the map.

The ground-moraine surface in the Souris River loop is intermediate in appearance between the two types just described. Undrained depressions are fairly small but numerous; knobs are not as plentiful as in the area between the Des Lacs and Souris Rivers but are much more numerous than southwest of the Souris River in Ward C'ounty.

Southeast of Velva, and to a lesser extent elsewhere, the surface of the ground moraine is modified by many shallow grooves. Some grooves are several miles long, but generally they are less than 5 feet deep and very indistinct except on aerial photos, where they are emphasized by the dark color of the vegetation in the grooves. The grooves are parallel to long linear ridges which have been mapped as a separate unit. Transverse to the ridges and grooves, and apparently related to them, are low subparallel arcuate ridges and chains of intervening undrained depressions. These transverse ridges are recessional moraines, sometimes 
called "washboard moraines," that mark cyclic pauses of the ice front during deglaciation. In the Velva area, most of the transverse ridges consist of segments alined in arcs, have uneven crests, and generally are less than 10 feet high. Such segmented arcs range from one-fourth mile to two miles in length. They are concave to the northwest, which indicates that the last ice front receded to the northwest. They are spaced irregularly and there may be sereral arcs per mile. Most are undiscernible on the ground without the aid of aerial photographs or a detailed topographic map. The relation of the grooves and linear ridges to the arcuate ridges is shown in plate 15 . The arcuate ridges and intervening undrained depressions are well illustrated in plate 15 and on the shaded-relief topographic map of the Voltaire (northeast quarter of Velva 15-minute quadrangle) quadrangle.

Indistinct arcuate features north and south of the town of Flaxton consist chiefly of chains of elongated undrained depressions. Like similar features southeast of Velva, they are concave to the northwest. There are no linear ridges and grooves, however.

\section{THICKNESS}

The ground moraine is unusually thick in most places, as compared with most other glaciated areas in the Great Plains. In general, it is thinnest near the Max moraine and, except for buried channels, thickens progressively to the northeast. Its greatest thickness is near the International Boundary in the Souris River loop area. In a strip 1-3 miles wide adjoining the Max moraine, the ground moraine is commonly 30-50 feet thick. Between this strip and the Des Lacs and Souris Rivers, it is about 150 feet thick. In the Souris River loop area, it thickens progressively from about 100 feet near Velva to about 250 feet north of Mohall. Along some buried channels, it might exceed 250 feet.

The thickness was determined by test drilling and from water-well data. From these data the topography of the underlying bedrock surface was reconstructed (see pl. 2). Thus, where topographic maps are available, the thickness of the ground moraine can be obtained by subtracting the bedrock altitudes shown on plate 2 from the surface altitudes shown on the topographic maps. ${ }^{1}$ As has been emphasized previously, large areas lack adequate data; hence, the reconstructed bedrock surface in places is very generalized, and unrecognized buried channels may be numerous.

\section{STRATIGRAPHIC POSITION AND AGE}

The ground moraine extends down to bedrock. The underlying bedrock belongs to the Tongue River mem-

\footnotetext{
1 The scale of plate 2 does not permit surface topography to be shown and topography is not available for part of the area.
}

ber of the Fort Union formation, except small areas along the eastern margin where the Cannonball member of the Fort Union formation and the Fox Hills sandstone underlie the deposits. The ground moraine is overlain, in places, by various types of outwash and stratified ice-contact deposits, and by Recent deposits.

The contact between ground moraine and underlying bedrock is remarkably smooth in most places, as though the top of the bedrock had been evenly eroded by the advancing ice and till had then been deposited without further disturbance of the bedrock. Where the underlying bedrock is the Tongue River member, the contact is usually at the top of a lignite bed. The contact of the ground moraine with outwash deposits and with stratified ice-contact deposits is generally sharp. The contact with the Max moraine is gradational. Ground moraine and deposits mapped as end moraines in the Souris loop area also grade into one another, but the end moraines generally contain a much higher proportion of stratified material.

Bodies of sand underlie the till southeast of the Souris River, in the area where the linear ridges are present. The areal extent and origin of the bodies of sand is not clear, but they do not everywhere underlie the till in that area.

All surface ground moraine is tentatively assigned to the Mankato substage, except supposedly older till that underlies a boulder belt along the valley walls of the Des Lacs River near Donnybrook, and possibly some till that underlies overridden ice-contact deposits along the valley walls of the Souris River between Minot and Verendrye. The age relations of the two last-mentioned deposits are discussed in greater detail under the heading "Special localities." As previously mentioned, tills of Iowan, Tazewell, and Cary substage probably are buried, at least locally, under the surface till; however, except for the till that underlies the boulder belt, all look alike and no way has been found to differentiate them. Therefore, they are included in the same map unit as the till at the surface.

\section{GRAIN SIZE, SHAPE, AND IITHOLOGIC COMPOSITION}

The ground moraine consists mostly of till but contains intercalated lenses of silt, sand, and gravel. In a few places, such as buried channels, large bodies of tillcovered outwash are present. Deposits of alluvium and colluvium in numerous kettles and other undrained depressions are not differentiated from the ground moraine. Thin colluvium, which mantles valley walls and other steep slopes underlain by till, also is undifferentiated because of its small areal extent.

The till consists chiefly of clay, silt, and sand, intermixed with pebbles, cobbles, and boulders. Grain-size 


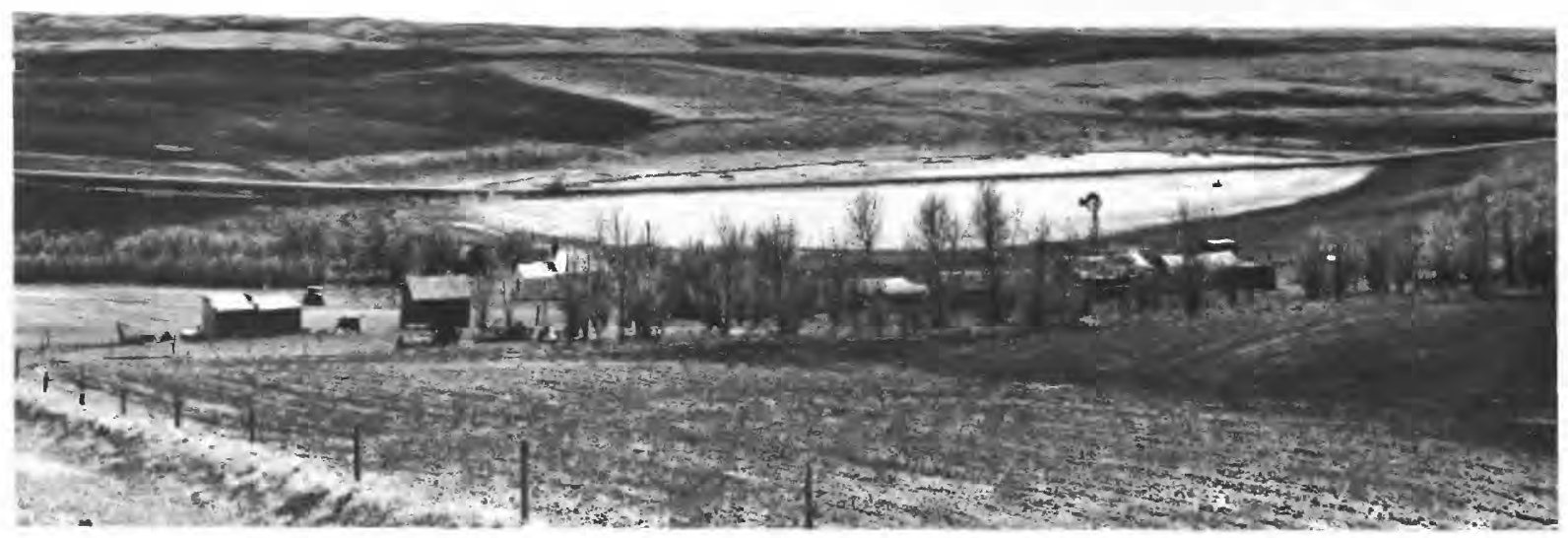

A. VIEW OF THE MAX MORAINE NEAR WESTERN EDGE OF MAPPED AREA, SHOWING CHARACTERISTIC ROLLING TOPOGRAPHY Undrained depression (kettle?) has an alkali-covered bottom. Photograph by R. C. Townsend.

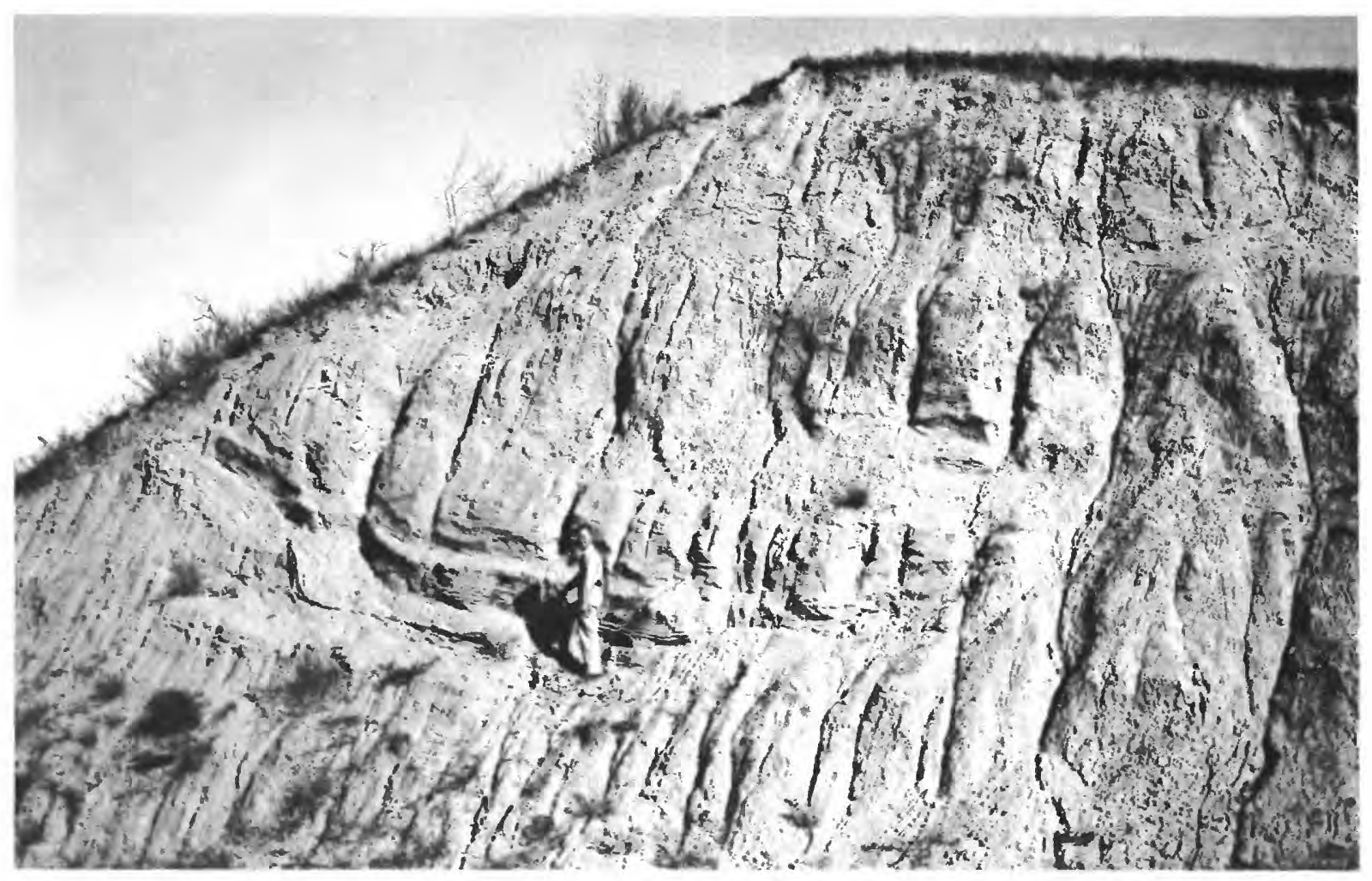

B. VIEW OF A ROAD CUT SOUTH OF MINOT, N. DAK., SHOWING DEFORMED LENSES OF SILT BEDS IN TILL 
analyses made by Lyman C. Huff, of typical samples of till are shown below; two other grain-size analyses are given under the heading "Special localities." These analyses, according to Wentworth's classification of grain size $(1922$, p. 377-392), show that about 25 percent of the till is clay, 40 percent silt, 30 percent sand, and 5 percent gravel. All these samples were taken from sites where the till is underlain by the Tongue River member of the Fort Union formation. Till underlain by the Cannonball member contains smaller percentages of clay and silt, and, hence, a larger proportion of sand.

The percentage of cobbles and boulders in the till was not calculated. Cobbles and boulders are conspicuous in places but are very minor constituents of the till. They are abundant locally along the valley walls of the Des Lacs and Souris Rivers and their major tributaries, along some of the larger glacial outwash channels, and elsewhere, where they have been left as lag concentrates. Boulders and cobbles are concentrated especially along the valley walls of the Des Lacs River from about a mile north of Kenmare to the International Boundary. Boulders $2 \frac{1}{2}$ feet long are common and some 4 feet long are not unusual. The largest in the Souris River area is south of Flaxton; it is a granitic rock about 10 feet long and 6 feet wide that projects 4 feet above the ground. The largest erratic in the northern Great Plains known to the writer is about 4 miles southeast of the Garrison Dam in central North Dakota. It consists of gneissic pegmatitic granite, is $221 / 2$ feet long and 17 feet wide, and projects 7 feet above the ground.

Many large boulders that lie on fairly flat surfaces occur in shallow depressions only slightly wider than the boulders themselves. Although there are conflicting explanations for this relation, the writer believes that the depressions were formed by the combined action of animals and wind. Formerly buffalo and later cattle rubbed themselves against these large boulders. In the process, the ground around the boulders was loosened by the animals' hoofs and carried away by the wind, and the boulders then settled into everdeepening holes.
Small lenses or irregular chunks of stratified silt, sand, and gravel are abundant in the till on the valley walls of the Souris River. The largest observed lenses are a few tens of feet in length, though larger unexposed bodies may exist. Thinly bedded lenses of tan silt are especially prevalent along the valley walls and tributaries of the Souris River in the vicinity of Minot. In a road cut on U. S. Highway 83,3 miles south of Minot in the SE $1 / 4$ sec. 2 , T. 154 N., R. 83 W., is exposed about 30 feet of till containing several irregular bodies of thinly laminated silt and fine sand (pl. $5 B$ ). The largest of the bodies is a lens about 30 feet in length and 8 feet in maximum thickness; its folded and faulted beds dip as much as $35^{\circ} \mathrm{SW}$. Other smaller more angular bodies of sand and silt in the exposure are evidently chunks of a much larger body.

Deposits in undrained depressions are derived from the adjacent moraine by slopewash and wind transportation; because of the swampy environment they generally have a high content of organic material. They range in thickness from a few inches to several feet and generally lack distinct bedding.

The shape of individual rock particles in the ground moraine depends mostly on grain size and, to a much smaller extent, on lithologic composition. Most boulders are subangular to subrounded, though some flat slablike carbonate boulders are several times longer than thick. Gravel-sized material is generally subangular, and about one pebble in ten has a length at least twice its width. Most sand particles are sharply angular.

Many lithologic pebble counts of the till have been made. Ten of these counts, tabulated on page 49, indicate that the pebbles longer than one-half inch consist of the following materials: 57 percent limestone and dolomite, about 12 percent granite and granite gneiss, 7 percent basic fine-grained rock, 6 percent other granitoid rock, 2 percent chert and other microcrystalline rock, 2 percent quartz and quartz aggregate, 2 percent quartzite, 0.4 percent schist and other foliated rock, and 11 percent miscellaneous rock.

Lignite chips and limonite blebs are minor but characteristic constituents of the ground moraine. Lignite

Weighted frequency, in cumulated percent, of grain size of ground moraine, Ward County, N. Dak.

[Sizes less than $0.0312 \mathrm{~mm}$ diameter determined by pipette method. Analyses by L. C. Huff]

\begin{tabular}{|c|c|c|c|c|c|c|c|c|c|c|c|c|c|c|c|c|c|c|}
\hline \multirow{2}{*}{ Location } & \multicolumn{4}{|c|}{ Diameter (in inches) } & \multicolumn{14}{|c|}{ Diameter (in millimeters) } \\
\hline & 3.00 & 150 & 1.472 & 0.371 & 4.699 & 2.362 & 0.991 & 0.589 & 0.295 & 0.147 & 0.074 & 0.0312 & 0.0156 & 0.00779 & 0.00388 & 0.00195 & 0.00098 & 0.00049 \\
\hline
\end{tabular}


Pebble counts shoving lithologic composition of pebbles more than one-half inch long, from glacial till in Manitoba, and in Bottineau and Ward Counties, N. Dak.

\begin{tabular}{|c|c|c|c|c|c|c|c|c|c|c|c|c|}
\hline $\begin{array}{ll}\text { [Gr } & \text { Gran } \\
\text { Ogr } & \text { Othe } \\
\text { Af } & \text { Acid } \\
\text { Bf } & \text { Basic } \\
\text { Qtz } & \text { Quar } \\
\text { ch } & \text { Schis }\end{array}$ & $\begin{array}{l}\text { te and granite gneiss } \\
\text { granitoid rocks } \\
\text { elsite and porphyry } \\
\text { fine-grained rocks } \\
\text { and quartz aggregate } \\
\text { and other highly foliated rocks }\end{array}$ & & $\begin{array}{l}\text { Qzt } \\
\text { Ld } \\
\text { Ch } \\
\text { M }\end{array}$ & $\begin{array}{l}\text { artzite } \\
\text { neston } \\
\text { ert and } \\
\text { adstone } \\
\text { tone, a }\end{array}$ & $\begin{array}{l}\text { and do } \\
\text { other } n \\
\text { siltsto } \\
\text { d argil }\end{array}$ & $\begin{array}{l}\text { mite } \\
\text { rocrys } \\
\text { shale }\end{array}$ & lline rc & limon & petı & wo & clink & r, green- \\
\hline Pebble & ontio & & & & & positi & (perce & & & & & Num- \\
\hline & & $\mathrm{Gr}$ & Ogr & Af & $\mathrm{Bf}$ & Qtz & Sch & Qzt & $\mathbf{L d}$ & $\mathrm{Ch}$ & $\mathbf{M}$ & counted \\
\hline $1 \ldots$ & $\begin{array}{l}\text { Ward County: } \\
\text { NW1/4 sec. } 36, \text { T. } 156 \text { N., R. } 84 \text { W } \\
\text { SW1/4 Sec. 34,T. } 157 \text { N., R. } 84 \text { W }\end{array}$ & $\begin{array}{l}18.7 \\
11.3\end{array}$ & $\begin{array}{r}12.5 \\
6.5\end{array}$ & $\begin{array}{l}0 \\
0\end{array}$ & $\begin{array}{r}6.3 \\
12.9\end{array}$ & $\begin{array}{l}2.7 \\
1.6\end{array}$ & $\begin{array}{l}0.9 \\
0\end{array}$ & $\begin{array}{l}2.7 \\
8.1\end{array}$ & $\begin{array}{l}48.2 \\
53.2\end{array}$ & $\begin{array}{l}0 \\
0\end{array}$ & $\begin{array}{l}8.0 \\
6.5\end{array}$ & $\begin{array}{r}112 \\
62\end{array}$ \\
\hline 3 & $\begin{array}{l}\text { Bottineau County: } \\
\text { NW1/4 sec. } 31 \text {, T. } 163 \text { N., R. } 79 \mathrm{~W} \\
\text { Manitoba, } 2 \text { miles north of Antler }\end{array}$ & $\begin{array}{l}10.1 \\
15.8\end{array}$ & $\begin{array}{l}1.0 \\
3.5\end{array}$ & $\begin{array}{l}0 \\
0\end{array}$ & $\begin{array}{l}16.2 \\
11.4\end{array}$ & $\begin{array}{l}0 \\
0\end{array}$ & $\begin{array}{l}0 \\
0\end{array}$ & $\begin{array}{l}3.0 \\
0\end{array}$ & $\begin{array}{l}64.7 \\
62.3\end{array}$ & $\begin{array}{l}3.0 \\
0\end{array}$ & $\begin{array}{l}2.0 \\
7.0\end{array}$ & $\begin{array}{r}99 \\
114\end{array}$ \\
\hline 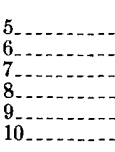 & 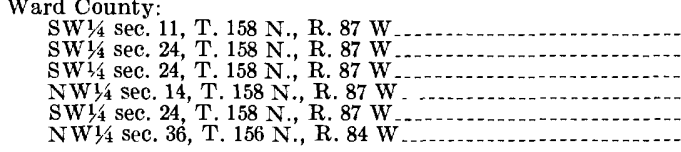 & $\begin{array}{r}8.6 \\
13.9 \\
12.5 \\
10.5 \\
8.9 \\
11.4\end{array}$ & $\begin{array}{r}12.0 \\
4.8 \\
6.3 \\
6.3 \\
0 \\
7.0\end{array}$ & $\begin{array}{l}0 \\
0 \\
0 \\
0 \\
0 \\
0\end{array}$ & $\begin{array}{l}5.1 \\
6.0 \\
6.3 \\
2.1 \\
3.2 \\
5.3\end{array}$ & $\begin{array}{l}6.8 \\
1.2 \\
0 \\
2.1 \\
.8 \\
2.6\end{array}$ & $\begin{array}{l}1.0 \\
0 \\
0 \\
0 \\
1.6 \\
0\end{array}$ & $\begin{array}{l}0 \\
.6 \\
1.1 \\
1.0 \\
2.4 \\
2.6\end{array}$ & $\begin{array}{l}57.7 \\
57.8 \\
57.4 \\
68.0 \\
55.6 \\
49.1\end{array}$ & $\begin{array}{l}0 \\
7.8 \\
0 \\
0 \\
3.2 \\
1.8\end{array}$ & $\begin{array}{r}6.8 \\
7.8 \\
16.4 \\
10.0 \\
24.2 \\
20.2\end{array}$ & $\begin{array}{r}117 \\
166 \\
86 \\
94 \\
124 \\
114\end{array}$ \\
\hline Average & - & 12.17 & 5.99 & 0 & 7. 48 & 1.78 & 0.35 & 2.15 & 57.40 & 1.58 & 10.89 & \\
\hline
\end{tabular}

chips generally are $1 / 16^{-1 / 4}$ inch long, but pieces $1-2$ inches long are common. Even the smallest pieces of lignite are unoxidized and fresh. Limonitic blebs, which are yellowish brown to brownish orange, are generally less than one-fourth inch long.

Pebble counts 7, 8, and 9 were taken from till beneath a boulder belt southeast of Donnybrook in Ward County. This till is believed to be older than the Mankato substage. It is significant to note that this older till contains a much higher percentage of materials in the miscellaneous category, which consists chiefly of fissile shale chips.

Pebble count 10 was made in a road cut along the valley wall of the Souris River, 1 mile north of its confluence with the Des Lacs River. The till of the exposure is very compact and looks different from typical Mankato till. It is believed to be of the Mankato substage, however, but overlies bedrock at shallow depth and contains much material derived from this bedrock, which accounts for its unusual appearance. Similar till in direct contact with the Fort Union formation has been noted in the southeast part of Ward County.

Granite and granite gneiss become increasingly abundant in size fractions beyond one-half inch. Boulders 1-2 feet in diameter are predominantly granitic, and nearly all boulders 3 feet or more in longest dimension are granitic. Almost all boulders 4 feet long or larger are of pink granite.

\section{PEBBLE ORIENTATION STUDIES}

Five pebble-orientation studies were made. The results are shown in figure 7 . Although definite preferred orientation of the pebbles was obtained in each analysis, the results as a whole were unclear. For example, analysis 1 , of a sample taken about 2 miles southwest of Karlsruhe in McHenry County, shows a preferred orientation to the southeast and nearly as strong a secondary orientation to the southwest, whereas analysis 4, taken about 2 miles northeast of Balfour in the same county, shows a preferred orientation to the southwest and a secondary orientation almost due south. The remarkably constant orientation of the drumlinoidal ridges and grooves in both areas, which are believed to be parallel to the direction of ice movement, strongly argues for the same direction of ice advance in both localities. The other three analyses, taken in the Sawyer and Minot quadrangles, show a definite preferred orientation to the southwest, without a pronounced secondary orientation.

\section{BEDDING AND SORTING}

Most of the till shows no evidence of bedding or sorting. Somewhat resembling bedding are local, essentially horizontal, threadlike stringers of sand and gravel in otherwise typical clayey till; or, less commonly, layers a foot or more thick consisting of till of slightly different color and texture.

The larger bodies of stratified sand and gravel in the ground moraine range mostly from poorly bedded to moderately well bedded, and from poorly sorted to well-sorted material. The smaller intercalated lenses and irregular-shaped stratified bodies display an even wider range of bedding and sorting. Well-bedded deposits occur commonly next to poorly bedded deposits.

\section{INDURATION, CEMENTATION, AND WEATHERING}

Partial cementation caused by an accumulation of caliche 2-5 feet below the surface is common. Because the till is fairly calcareous, carbonates are leached from the top soil zone and are brought up from below by 

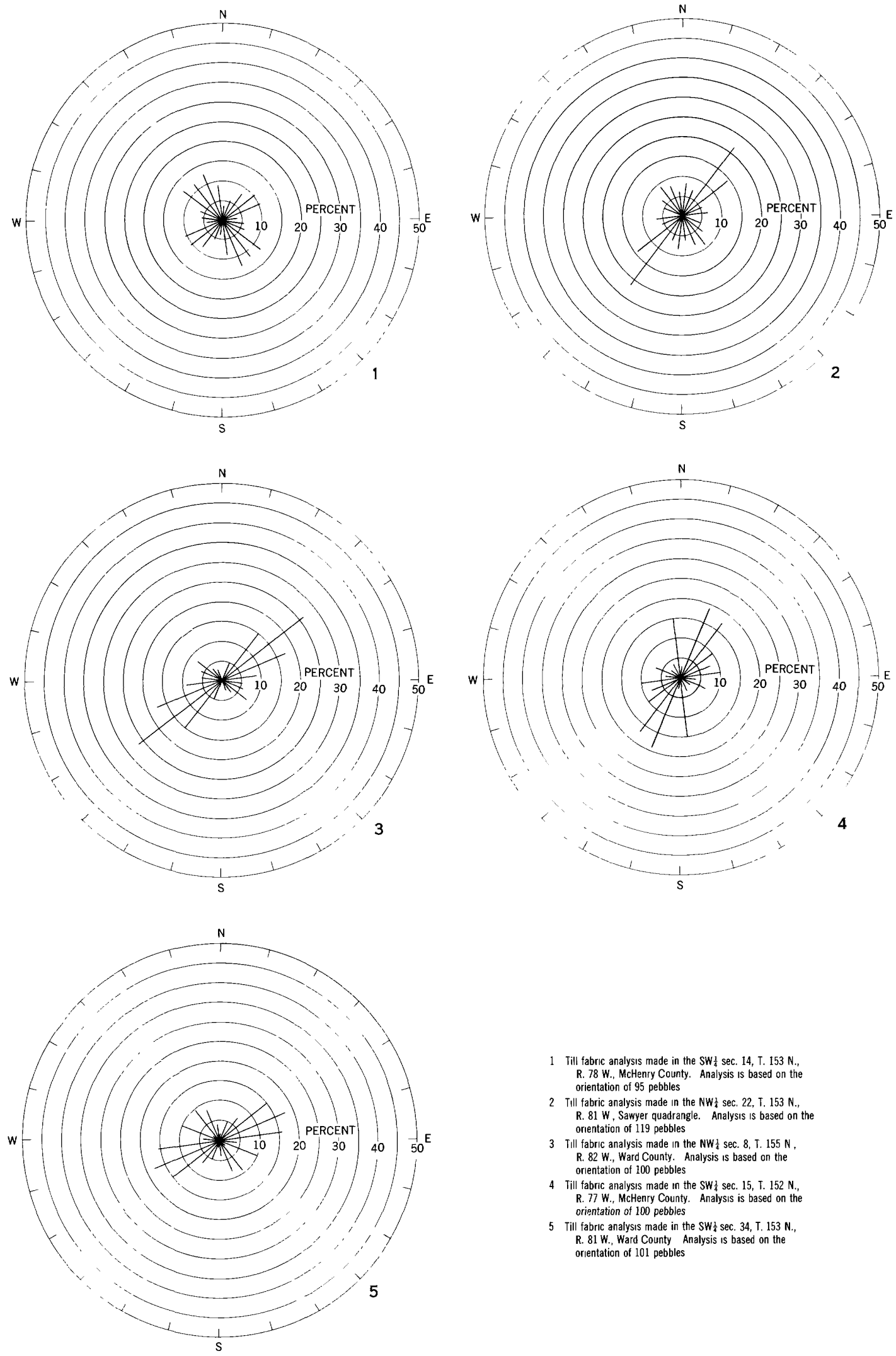

R. 78 W., McHenry County. Analysis is based on the

In the NW $\frac{1}{4} \sec .8$, T. $155 \mathrm{~N}$

R. 77 W. Metsery Couty.

R. 81 W. Ward County Analysis is based on the

orientation of 101 pebbles

Figure 7.--Rose diagrams showing orientation of pebbles in till. Each circle represents 10 percent of total number of pebbles. 
capillary action, forming caliche. Flat pebbles in this zone are commonly encrusted with caliche, especially on their under sides. Where pebbles are fairly abundant in this zone, cementation is greater than where pebbles are sparse, but the till is nowhere completely indurated.

Both oxidized and unoxidized tills are tough when wet, but they can be cut with a hand shovel rather easily. When dry, however, till is very hard except for the upper few feet and is hard to dig with a pick.

Nearly all till exposures are oxidized and are grayish $\tan$ to light grayish brown. In the few places where unoxidized till is exposed it is grayish blue. Oxidized till underlain by the Cannonball member is commonly more tan or yellow than till underlain by the Tongue River member.

Oxidation in till of the Mankato substage extends almost every where to a depth of 30 feet; in most places it exceeds 50 feet. Excepting a color change, which is probably produced chiefly by oxidation of iron, no weathering effects other than calichification are discernible. Oxidation is caused by surface water moving down small cracks or joints in the till and slowly spreading laterally. Along cracks and joints, oxidation commonly extends a few inches into each wall toward unweathered till. In places where lateral cracks or porous partings intersect vertical cracks, blocks of unweathered till are enclosed by rinds of oxidized till.
SPECIAL LOCALITIES

Tills that appear to be of two different substages are exposed in a road cut of U. S. Highway 52, 11/2 miles southeast of Donnybrook, in the SW1/4 sec. 24 , T. 158 N., R. 87 W. Their relation is shown in figure 8. The upper till is part of the ground-moraine plain and was deposited during the Mankato substage. The lower till probably is Tazewell or Iowan in age. Locally a conspicuous boulder pavement marks the contact.

Superficially, the two tills are similar. The lower till, however, is light gray to light tan, whereas the upper till is considerably darker. The color difference appears to be due to the fact that the lower till is more oxidized, although the lower till has not been weathered sufficiently to decompose any of its contained pebbles. The lower till is more compact than the upper till, but it contains many small irregular fractures 2-4 inches apart, coated with a thin orangebrown film of iron oxide or, less commonly, brownishblack manganese oxide. Fractures in the upper till are not coated.

The two tills are similar lithologically, but the lower till contains the greater number of dark-gray flat shale chips. Pebble count 6 (see p. 49) shows the lithologic composition of material larger than one-half inch in the upper till, and pebble count 7 shows the composition of the lower till. Many of the pebbles in the lower till are speckled and mottled with manganese

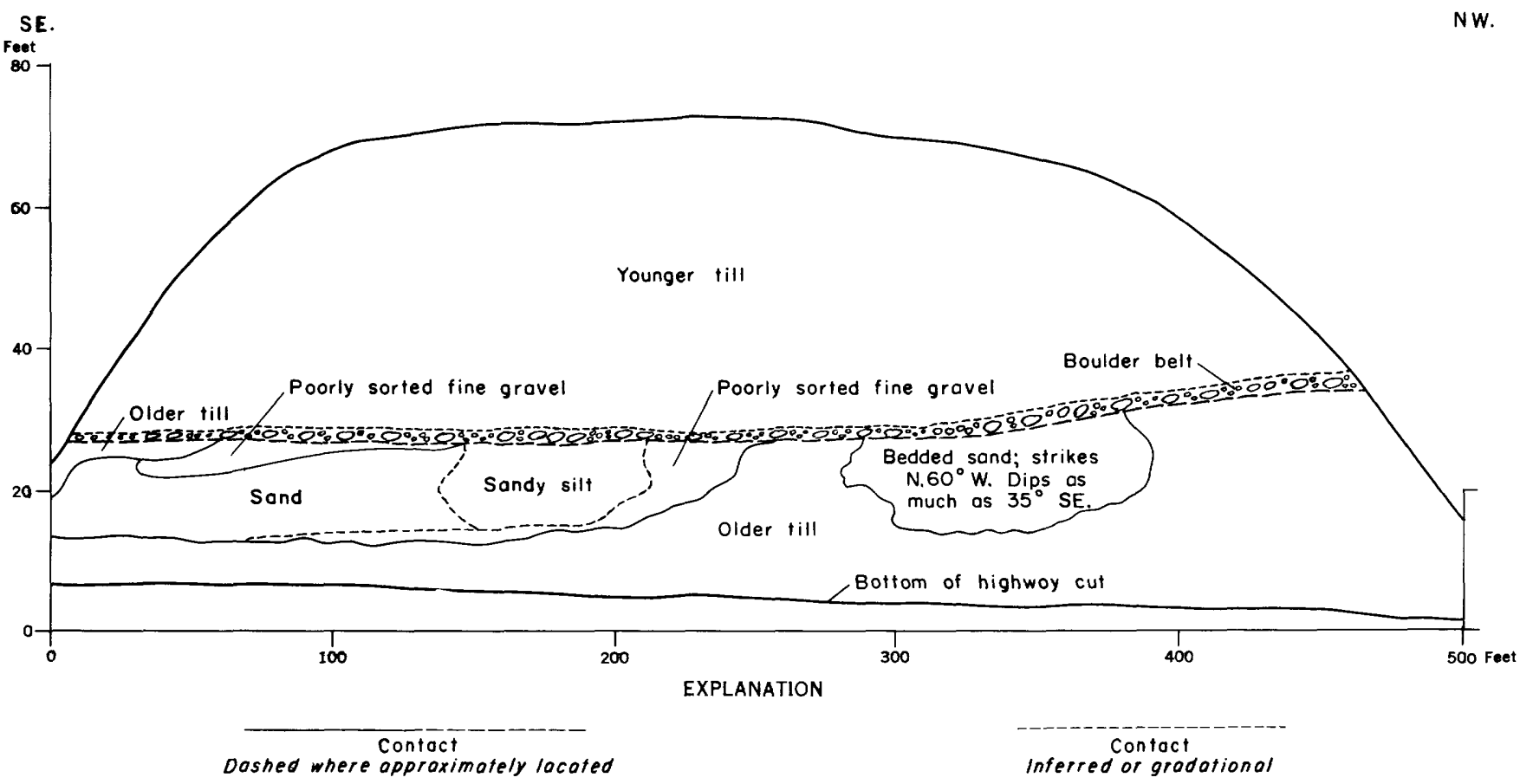

Figure 8. - Section along highway cut in Warl County, 11/2 miles southeast of Donnybrook showing two tills separated by a boulder belt. 
dendrites, but such mottling is almost totally absent from the pebbles in the upper till. As shown in the table below, mechanical analyses of the minus-6-mesh fraction of both tills show a remarkable similarity in grain size. The plasticity index of the lower till is 21, about the same as the Mankato till.

Sieve analyses of upper and lawer tills, $1 \frac{11}{2}$ miles southeast of Donnybrook, N. Dak.

[Tested by the U. S. Bureau of Public Roads Laboratory, Denver, Colo.]

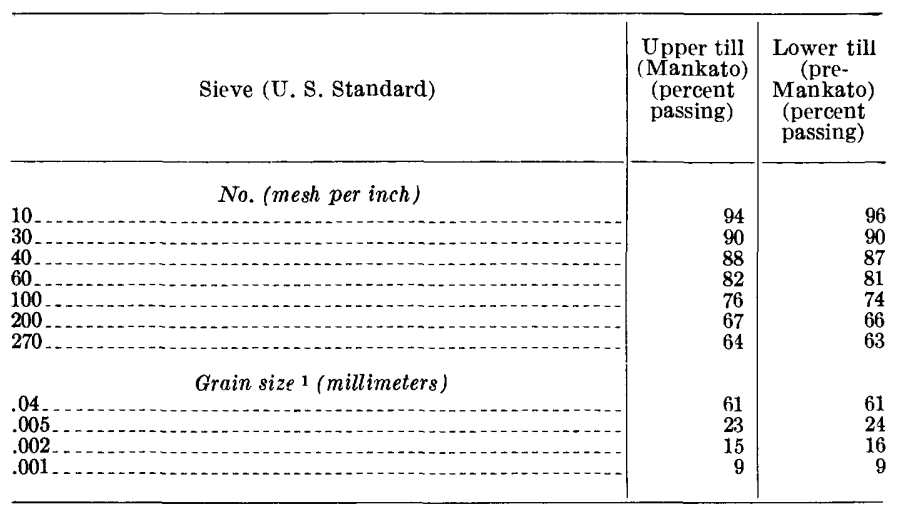

1 Size of silt and clay range determined with hydrometer.

Intercalated in the lower till, and probably contemporaneous with it, are glaciofluvial deposits. The deposits are predominantly crossbedded sand but contain finely laminated buff-colored silt and shale-rich gravel. There are many dendrite-mottled pebbles similar to those in the lower till. The beds are tilted $35^{\circ} \mathrm{SE}$ and strike $\mathrm{N} .60^{\circ} \mathrm{W}$. The beds are within the lower till rather than interglacial, because they are partly overlain by the lower till. Conspicuous dark-gray shale fragments, mottled pebbles, and tilted bedding strongly suggest that these deposits are remnants of a kame terrace and contemporaneous with gravels in a pit about 1,000 feet to the north west.

The zone of boulders and cobbles, generally less than 3 feet thick, between the two tills contains boulders $41 / 2$ feet long, though their average size is about 2 feet. In places, the boulders form a well-defined pavement. Many are polished and striated, especially on their top surfaces. The boulders appear to represent a lag concentrate left by erosion of the lower till. The boulder zone dips down-valley and clearly truncates the glaciofluvial deposits in the lower till. The exposure was examined by James Thorpe and other soil scientists of the U. S. Department of Agriculture, who found no soil zone associated with the boulder pavement. However, a soil zone is not likely to be preserved in places where erosion has been active.

The boulder belt is discernible in several places on the opposite valley wall and is well defined for a distance of about 3 miles near Domnybrook (see pl. 1).
On the same side of the valley as the road cut exposing the two tills, the boulder belt is less conspicuous but is discernible for a short distance along the walls of a tributary valley between the road cut and the gravel pit to the north west.

If the dip of the boulder belt is projected from the road cut to the gravel pit, which is about 1,000 feet to the northwest, the boulder belt appears to join the limeenriched bed at the back of the gravel pit (see p. 57.) The lime-enriched bed probably also marks the contact between two different tills in that exposure. This probability, together with the abundance of shale chips in both the glaciofluvial deposits in the lower till in the road cut and in the deposits at the gravel pit, and the presence of dendrites on the pebbles in both localities, strongly indicate that the two deposits in the two exposures have the same origin and that the lime-enriched bed is equivalent to the boulder belt.

The age of the till under the boulder belt is speculative. Inasmuch as the overlying till is tentatively assigned to the Mankato, the underlying till might belong to the next oldest substage, namely the Cary substage. However, Flint (oral communication) and other workers believe that the large time break in the Wisconsin stage was between Tazewell and Cary time and that there was only a small interval of time between the Cary and the Mankato and between the Iowan and the Tazewell. Considerable oxidation in the older till, together with the erosion of the surface of the older till, suggests a considerable interval of time. Hence, an Iowan or Tazewell substage seems more likely than Cary. Judging from its apparently slight weathering, the till is not older than Wisconsin. Also, tills older than Wisconsin have not been recognized by Benson (1952, p. 184-194) south of the area.

A second locality of ground moraine that needs to be discussed separately is in Bottineau County, east of the Souris River in the northeast part of the mapped area. The surface of the ground moraine in this area differs in appearance from the surface of the ground moraine exposed elsewhere. The surface is studded with boulders and has a washed appearance, as though the fines had been removed by fluvial action. A thin veneer of silt, possibly windblown, covers the area locally but has not been differentiated on the map. Very indistinct "washboard" moraines that are concave to the northeast can be detected on aerial photographs but are not distinguishable when looked for on the ground.

The area of ground moraine east of the Souris River, in the northeast part of the mapped area, is lower in altitude than the maximum height of glacial Lake 
Souris in that vicinity. However, the area appears to have been covered by ice during the time the lake was at its maximum and therefore was not inundated by lake water. The configuration of the "washboard" moraines suggests that the margin of the lobe of ice in this area melted to the northeast toward the Turtle Mountains. Because silt, which is identical in appearance to nearby lake deposits, locally covers the ground moraine, it is difficult to determine where the contact should be between ground moraine and lake deposits.

\section{ORIGIN, TYPE, AND HISTORY OF DEPOSIT}

The ground moraine is derived locally and from a source many miles to the north in Canada. Most of the clay, silt, and sand in the till probably came from a local source, whereas nearly all the material of larger than sand size was brought in from Canada. A comparison of the lithologic composition of the till with the regional bedrock geology supports this belief. Shale, clay, siltstone, sandstone, and sand of Tertiary and Late Cretaceous age form the surface bedrock in northern North Dakota, southern Manitoba, and Saskatchewan. Because these materials were the last to be crossed by the ice, they constitute the bulk of the till. The Tongue River member of the Fort Union formation, which covers a large part of the mapped area and extends northward, into Canada, probably furnished the greater part of this finer fraction. This belief is supported partly by the presence, dispersed through the till, of numerous lignite fragments of probable Fort Union age. It is also significant that till which overlies the Cannonball member of the Fort Union formation is sandier and more tan or yellow than till which overlies the Tongue River member-a direct reflection of the lithologic composition of the bedrock. Pierre shale forms the bedrock surface in Canada northeast of the Souris River loop area, but it probably contributed very little material to the surface deposits of the mapped area, inasmuch as the last ice probably advanced from the northwest. However, abundant shale chips in the till and stratified material in the deposits underlying the boulder belt in the road cut $1 \frac{1}{2}$ miles southeast of Donnybrook might have been derived from Pierre shale. If so, the ice that deposited the lower till might have advanced from the northeast.

All the carbonate, granitic, and gneissic rocks in the ground moraine have been derived from Canada. According to W. M. Laird (oral communication) some of the carbonate rocks are Silurian and Ordovician in age, and it is probable that most of the carbonate rocks in the area are either of these ages or of Devonian age. North of the Souris River area in Canada, a belt of
Silurian and Ordovician outcrops trends southeast. Devonian strata flank this belt on the southwest. The closest source of these carbonate rocks is about 150 miles northeast of Westhope. However, if the last ice sheet advanced from the northwest, as supposed, the source was much more distant.

All of the granitic rocks are believed to have been derived from the Canadian shield. The closest source of these rocks is about 300 miles northeast of Westhope but the source was much farther if the rocks came from the northwest.

How much of the ground moraine is lodgment till and how much is englacial and ablation moraine is not known because of the uniformity of the till. Flint (1947, p. 113) and others believe that ablation moraine generally is less compact than lodgment till and has relatively more coarse material, owing to removal of fines by melt water. In the Souris River area, however, ablation moraine is almost lacking or cannot be distinguished from lodgment till. The latter possibility seems more likely. Lenses of till incorporated in kame and esker deposits, for example, must be of englacial or superglacial origin. In several such deposits, till incorporated in these stratified deposits appears the same as till found in exposures 50 or more feet below the surface, which almost certainly is lodgment till. The upper few feet of the till of the ground moraine is less compact and, in some places, contains a higher proportion of coarse material than the till at depth. However, it is believed that the lack of compactness is due in part to oxidation, which extends to depths of 30-50 feet, and in part to frost action, which tends to churn the upper $3-5$ feet of the deposits.

The origin of small, irregular deposits of silt and sand in till that occurs along the valley walls of the major rivers is not entirely clear. They may have formed, however, in small ponds on the ice, along the margin of the ice, or under the ice. Subsequent melting of the supporting ice on one or more sides may have caused the deposits to collapse, deforming the bedding. The deposits were then overriden by ice and till was deposited on them. Some of the more angular bodies may have moved as frozen chunks into their present position before they were again overriden.

\section{ENGINEERING GEOIOGY}

The following data are based in part on field observations, in part on service records of performance, and in part on laboratory analyses. It should be emphasized that the analyses were made in the laboratory and might differ considerably from analyses made on undisturbed ground moraine. This supposition is espe- 
Physical characteristics of till in McHenry and Ward Counties, N. Dak.

\begin{tabular}{|c|c|c|c|c|c|c|c|}
\hline Location & $\begin{array}{l}\text { Specific } \\
\text { gravity }\end{array}$ & $\begin{array}{c}\text { Compact- } \\
\text { ness } 1\end{array}$ & Porosity & $\begin{array}{c}\text { Permea- } \\
\text { bility (cm } \\
\text { per min) }\end{array}$ & $\begin{array}{l}\text { Liquid } \\
\text { limit }\end{array}$ & $\begin{array}{l}\text { Plastic } \\
\text { limit }\end{array}$ & $\begin{array}{l}\text { Plastic } \\
\text { index }\end{array}$ \\
\hline $\begin{array}{l}\text { McHenry County: } \\
\text { SW } 1 / 4 \text { sec. } 35, \text { T. } 153 \text { N., R. } 80 \text { W.... }\end{array}$ & 2.67 & 4.5 & 42.0 & 0.0001 & 40.0 & 18.0 & 22.0 \\
\hline $\begin{array}{l}\text { Ward County: } \\
\text { SE1/4 sec. } 33 \text {, T. } 153 \text { N., R. } 81 \text { W. } \\
\text { SW14 sec. 19, T. } 155 \text { N., R. } 81 \text { W. } \\
\text { NW14 see. 13, T. } 154 \text { N., R. } 83 \text { W. } \\
\text { SE1/4 sec. } 35 \text {, T. } 157 \text { N., R. } 82 \text { W. }\end{array}$ & $\begin{array}{l}2.71 \\
2.67 \\
2.66 \\
2.75\end{array}$ & \begin{tabular}{l|}
4.9 \\
2.14 \\
5.55 \\
4.34
\end{tabular} & $\begin{array}{l}37.4 \\
42.4 \\
41.3 \\
37.2\end{array}$ & $\begin{array}{l}.00009 \\
.004 \\
.0001 \\
.00007\end{array}$ & $\begin{array}{l}37.9 \\
29.8 \\
33.7 \\
29.2\end{array}$ & $\begin{array}{l}15.9 \\
14.5 \\
17.3 \\
13.4\end{array}$ & $\begin{array}{l}\text { 22. } 0 \\
\text { 15. } 3 \\
\text { 16. } 4 \\
15.8\end{array}$ \\
\hline
\end{tabular}

I Percent shortening of sample when pressure is increased from $8 \mathrm{lb}$ per sq in to $16 \mathrm{lb}$ per sq in.

cially true of permeability. The vertical prismatic fracture pattern of surface till, as well as the presence of some horizontal permeable partings, probably permits a greater permeability than is indicated by laboratory tests. On the other hand, till at depth, especially unoxidized till, is probably more impermeable and also more compact than the following analyses indicate.

Drainage and permeabitity.-There is little surface drainage. Furthermore, permeability of the till is so slight as to be negligible (see table above); hence water commonly remains in the undrained depressions until evaporated. The bottoms of some depressions are coated with soluble salts, especially where bedrock is at a shallow depth; bedrock is presumably the source of most of the salts.

Workability and compaction.-The till is difficult to dig with hand tools but is worked easily with heavy power equipment. When nearly dry, it breaks into blocky fragments along vertical prismatic jointing; when wet, it is plastic and sticky. Blasting may be necessary to break up local caliche zones. Some large boulders may require special handling. Good compaction of the till is attained by use of sheepsfoot rollers and other roller equipment if moisture is controlled. Tests by the North Dakota Highway Department on till in the upland west of the Des Lacs River showed a plasticity index ranging from 25 to 30 and a Bureau of Public Roads soil classification of A-6 (Kaye, C. A., written communication).

stability and strength.-Slopes of all angles are fairly stable when dry. When slopes are wet, failure commonly occurs along vertical prismatic contraction joints, and chunks one to several feet across move downslope. Movement along vertical surfaces, as pointed out by Kaye (written communication), tends to maintain a vertical face in a pit even though the initial sides of the pit may not have been vertical. Laboratory tests of well-graded till would probably not indicate failure along the vertical contraction joints, although it is readily discernible in the field.

Kaye and the writer examined numerous artificial cuts in till to determine slope stability under different conditions. Some of Kaye's observations (written communication) are given below :

Slumping of glacial till was observed in numerous cuts along the Minneapolis, St. Paul and Saulte Ste. Marie railroad tracks on the east side of the Des Lacs valley north of Kenmare. The cuts range up to 35 feet in height and apparently have been maintained at slopes of $1: 1$.

The deep cut made by Highway 52 where it crosses the Des Lacs valley east of Bowbells is in till. Slides occur in this cut and were noticed to develop with particular rapidity during and soon after heavy rains. The backslope of the cut is $1: 1$.

The abandoned opencut lignite mine west of Bowbells contains some interesting examples of the slumping of till. This mine was active in the late 1930 's and early 1940's. At present it is a broad, water-filled trench with perpendicular sides. The level of the water in the summer of 1946 was approximately 20 feet below the top of the pit. In much of the pit, glacial till extends from the surface to, or nearly to, the water level. The sides of the pit are marked by numerous blocks of till in the act of settling as vertical slices. The process of sliding along vertical surfaces tends to maintain a vertical face to the pit, although it is questionable whether the initial pit sides were absolutely vertical. . .

Remoulded glacial till, on the other hand, exhibits a fairily high slope stability where examined in the large dump piles surrounding the Bowbells strip mine. Some sliding of the dump material was noted but this has been interpreted as being due to the failure of the underlying Fort Inion strata on which the till pile was resting. Piles made up predominantly of till exhibit no failure.

When compacted properly, till has high foundation strength. Frost heave is generally fairly low, owing to high impermeability of deposits.

Possible uses.-Till makes a good impervious fill for dams, for canal linings, and for other purposes. It also makes a stable subgrade for roads during periods of dry weather; but after prolonged rains, unsurfaced roads of till become nearly impassable owing to the high plasticity of the till. Till has also been used to a limited extent as a surface binder in sandy areas, as in the bed of glacial Lake Souris, where the sand lacks sufficient cohesion to be used for subgrade without such a binder. Foundations for buildings of all sizes built in till are relatively stable. Frost penetration is generally about 4 feet but reaches a maximum of $61 / 2$ feet. 


\section{OVERRIDDEN ICE-CONTACT DEPOSITS}

NAME, LOCATION, AND AREAL EXTENT

Stratified ice-contact deposits overridden by till are exposed locally along the valley walls of the Souris River and up some tributaries for distances of $1 / 4-3 / 4$ mile from Minot to near Verendrye. These deposits may be kame terraces. A few similar deposits are exposed in Ward County about 11/2 miles southeast of Donnybrook, but because of their very small extent they are not shown on the map. Most outcrops are less than 200 feet wide, and many of them less than 100 feet; hence the width of some exposures is exaggerated on the map.

\section{TOPOGRAPHY}

The deposits, in most places, crop out about one-third of the way up the valley walls. Because of their composition, they are somewhat more resistant to erosion than the adjacent till and thus form indistinct benches along the valley walls, especially on long sloping spurs, or interfluves, extending from the top of the valley wall to the valley bottom.

The deposits slope downstream at approximately the same gradient as the present valley floor. The surface of the deposits is at an altitude of 1,600 feet at Minot and about 1,520 feet in the vicinity of Verendrye.

\section{THICKNESS}

Deposits range in thickness from a few inches to about 30 feet, although deposits $5-15$ feet thick are most common. They are generally thicker in the valley walls of the Souris River than along its tributaries.

\section{STRATIGRAPHIC POSITION AND AGE}

In most places between Velva and Verendrye, the deposits are overlain and underlain by till. The overlying till is probably Mankato, but the age of the underlying till is unknown. The underlying and overlying tills are identical in appearance. Therefore, it is not known whether the stratified ice-contact deposits were laid down in Mankato time between two advances of the same ice front, or whether the underlying till belongs to an older glaciation.

The till underlying the kame terrace deposits $11 / 2$ miles southeast of Donnybrook is more oxidized than the till overlying the deposits between Minot and Verendrye. This supports the belief that the till near Donnybrook is older than Mankato and opens up the possibility that the overridden ice-contact deposits in this area also are older than Mankato substage and are not of the same age as those between Minot and Verendrye. This problem is discussed further under the heading "Special localities."
GRAIN SIZE, SHAPE, AND IITHOLOGIC COMPOSITION

The deposits consist mostly of fine to coarse sand and fine to coarse gravel. Fine gravel probably predominates. Laminated silt occurs locally. A gravel pit on the northern outskirts of Minot, in the NE1/4 sec. 14, T. 155 N., R. 83 W., exposes inclusions of till as much as several feet long. Boulders are uncommon.

The gravel is generally subangular, the larger pieces being somewhat more rounded than the smaller ones. The sand is mostly angular.

The lithology of the deposits is nearly the same as that of deposits derived from river terraces, diversion channels, and ice-marginal outwash having the same range in grain size. Carbonate rocks predominate in the fine-gravel fraction; granitic and gneissic rock are next most abundant. In the coarser gravel, granitic and gneissic rocks are nearly as abundant as carbonate rocks, whereas among boulders granitic and gneissic rocks are predominant. Most of the sand grains are quartz; feldspar is next most abundant. Some deposits contain till lenses 1-3 feet long and till balls (chunks of till that have been rounded by running water) as much as 8 inches in diameter.

\section{BEDDING AND SORTING}

Bedding is indistinct in many exposures where the predominant size fraction is larger than two inches; in general, the coarser the material, the more poorly it is sorted. Coarse gravel is usually very dirty and is iron stained to a yellowish-brown or orange-brown color. In contrast, beds of sand are clean and contain little or no iron oxide. Adjacent beds commonly range widely in grain size; in many places unsorted coarse gravel is in contact with well-sorted sand.

Nearly all beds are considerably deformed. Many are steeply tilted, and some are probably overturned. A few beds are folded. Shear planes and small faults showing offsetting of a few inches to several feet are common. Most of the deformation appears to be due to collapse as a result of melting of supporting ice. Some deformation, however, may have been caused by the overriding of the deposits by ice.

\section{INDURATION, CEMENTATION, AND WEATHERING}

A caliche or carbonate-enriched zone, 2-5 feet thick, commonly forms in the upper part of the deposits. Flat-lying pebbles usually have a carbonate encrustation, as much as one-eighth inch thick, on their under sides. Caliche is especially conspicuous in poorly sorted deposits, whereas there is nearly none in deposits such as clean sand. The carbonate apparently has been leached from the soil zone and, also, has been brought from below by capillary action. Some 

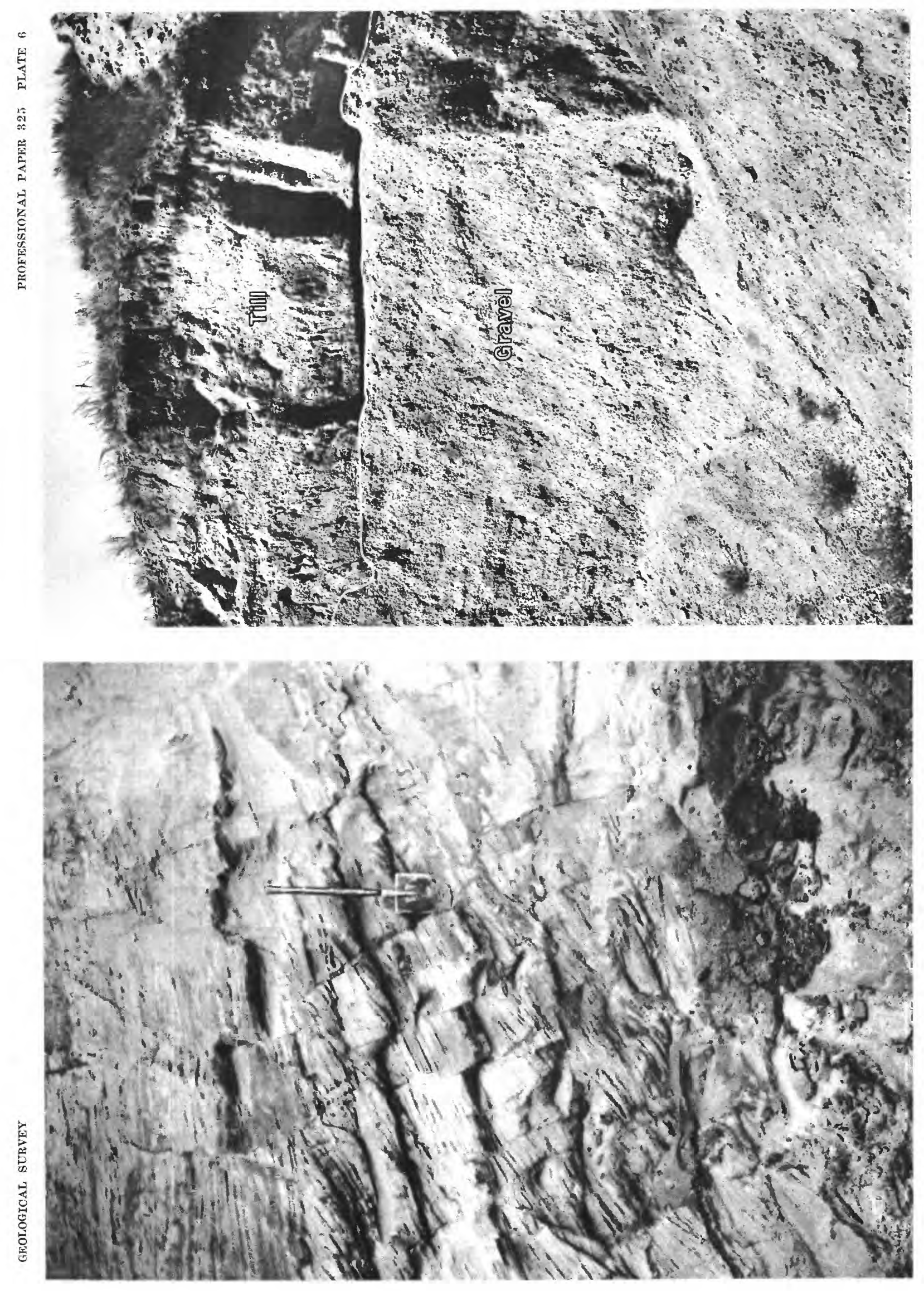

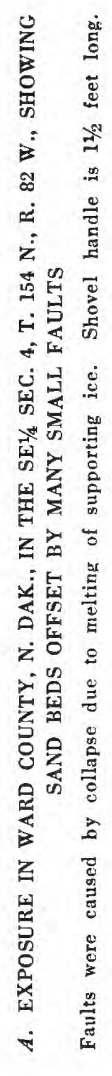


poorly sorted deposits also contain randomly distributed layers as much as 2 feet thick, cemented with iron oxides.

One type of cementation appears to be going on at the present time. From a point near a gravel pit one-half mile northwest of Velva to a point near another gravel pit one-half mile northeast of Velva, the basal 2-4 feet of the deposit is cemented with calcium carbonate into a moderately consolidated conglomerate. The base of this conglomerate appears to be on bedrock. Springs that issue from the conglomerate apparently are depositing the cementing material.

The only rock types affected to any extent by weathering are gneisses and granitic gneisses that contain abundant biotite. Hydration of the biotite in these rocks has mechanically disintegrated the rock, and the minerals have separated out as individual grains. That the process is chiefly disintegration rather than decomposition is shown by the fact that all the other mineral grains - even the feldspars, which are usually easily decomposed-are fresh and unaltered.

\section{SPECIAL LOCALITIES}

Three exposures in Ward County, described below, illustrate the variations in grain size, bedding, deformation, and other features that characterize the deposits.

One exposure is about 5 miles southeast of Minot along the south valley wall of the Souris River, in the $\mathrm{SE} 1 / 4$ sec. 4, T. 154 N., R. $82 \mathrm{~W}$. In the lowermost of two pits, about 40 feet above the valley floor, 15 feet of clean thinly bedded fine to medium sand is exposed. The beds are characterized by numerous small moderate- to high-angle faults. Offsets are only a few inches, but the faults are so closely spaced that the entire face of the exposure consists of rectangular blocks of sand $1 / 2-11 / 2$ feet long (pl. $6 A$ ). Faulting probably was caused by collapse of the beds, owing to melting of supporting glacier ice. In a nearby pit, gravel at a slightly higher elevation than the sand in the lower pit is overlain by till.

A second noteworthy deposit was observed in an exposure, now obliterated, in a gravel pit on the northern outskirts of Minot, on the west side of U. S. Highway 83 in the NE1/4 sec. 14, T. 155 N., R. 83 W. Medium gravel 10-20 feet thick was exposed in sharp contact with overlying till ( $p l .6 B$ ). The gravel was very poorly sorted and showed almost no bedding, but it incorporated attenuated till lenses, 1-3 feet thick and several feet long, and also sparse till balls, as much as 8 inches in diameter. The gravel was considerably deformed. Faults having offsets of 2-3 feet were common, and some beds were folded and crumpled, includ- ing a conspicuous layer, cemented with iron oxides, that was crumpled into tight folds about 1 foot high and 1-2 feet between the limbs of the folds. Like the deposit 5 miles southeast of Minot, this deposit was apparently laid down in contact with ice-probably between a former valley wall of the Souris River and glacier ice that occupied most of the valley. After the ice melted, the gravel was without support and collapsed, to be overridden later by readvancing ice, which in turn deposited till.

A third overridden ice-contact deposit is exposed in a gravel pit near a valley wall of the Des Lacs River, in the SW1/4 sec. 24, T. 158 N., R. 78 W. Although this deposit appears to antedate the deposits between Minot and Verendrye, it is described here because it is similar in character and origin.

An unusually thick section of steeply dipping and contorted beds of gravel, sand, and silt is exposed beneath till. Although direct evidence is lacking, nearby exposures (see description under the heading "Ground moraine") indicate that these stratified deposits are incorporated in a till belonging to an earlier substage than the overlying till in the southwest edge of the pit. The gravel, sand, and silt are well sorted and stratified. Crossbedding is common. The sand is light gray except for many dark streaks caused by a concentration of lignite chips and shale fragments. The gravel contains abundant rounded pebbles of a very fissile light-gray shale and cream-colored dolomitic limestone. Speckled and mottled with manganese dendrites, the limestone pebbles resemble bird eggs. The gravel also contains a great variety of other sedimentary and crystalline rocks commonly found in the drift. Interbedded with the sand and gravel, and cómmonly in sharp contact, are a few beds of laminated silt and minor amounts of dark-gray clay, which range in thickness from 1 to 10 feet. The silt is conspicuously crossbedded.

At the north edge of the pit, the beds are nearly vertical to slightly overturned, owing to collapse as a result of melting of the supporting ice after deposition (see fig. 9). Some of these beds are in contact with overlying till and appear to have been dragged southeastward along the contact by the overriding ice that deposited the till.

The dip of the beds decreases to the southwest. Near the southwest edge of figure 9 , a silt bed $21 / 2$ inches thick strikes N. $57^{\circ} \mathrm{W}$. and dips $71^{\circ} \mathrm{SW}$. The strike remains fairly constant across the pit, but the dip decreases to $32^{\circ} \mathrm{SW}$ near the south face of the pit. Faults are common. In the northeast end of the pit, many of the major faults are along bedding planes, but nearly horizontal thrust faults are common that 


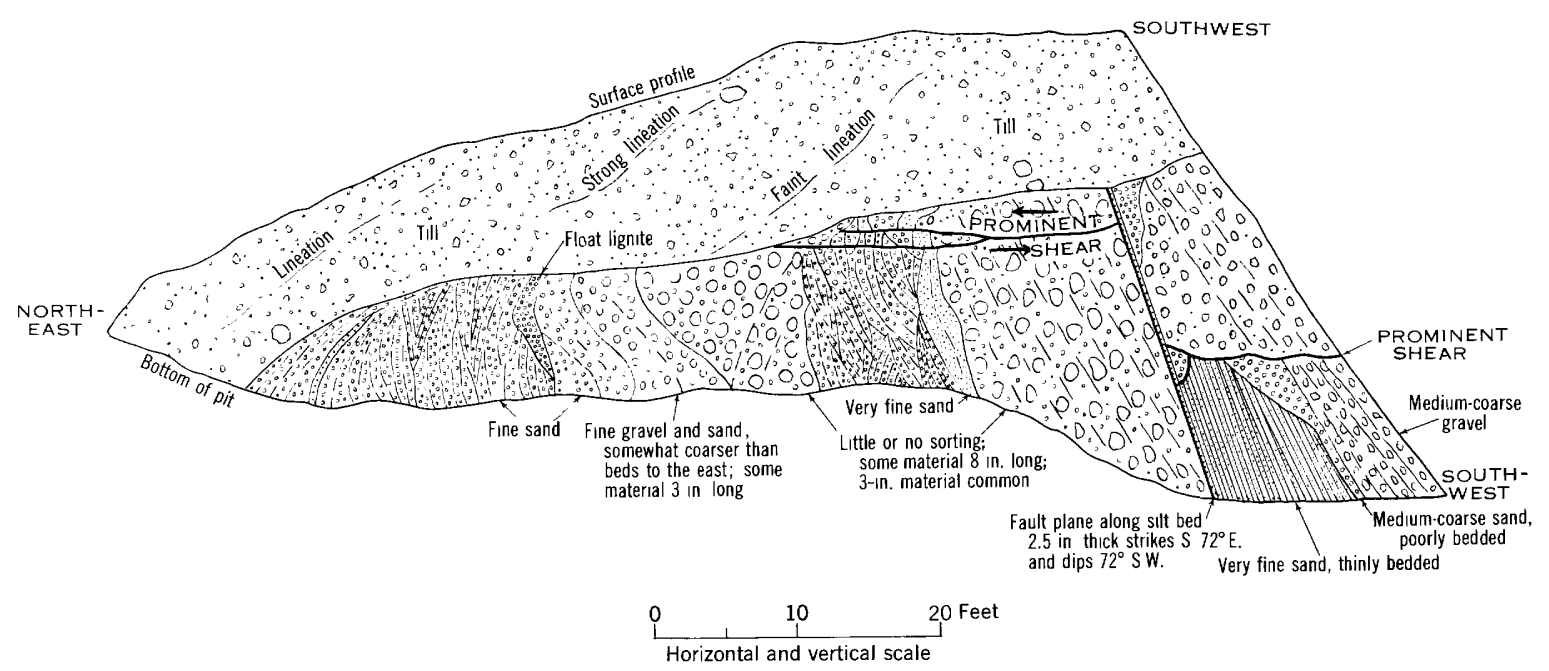

Figure 9.-Cross section in gravel pit $1 \frac{1 / 2}{2}$ miles southeast of Donnybrook, N. Dak., in the SW1/4 sec. $24, T$. 158 N., R. 78 W.

have known displacements ranging from a few inches to more than 15 feet. Toward the southwest end of the pits the faults are smaller but more numerous, and the beds are more severely folded, in places highly convoluted. The decrease in dip and number of faults as observed going from northeast to southwest across the pit suggest that collapse of the deposit was due chiefly to melting of supporting ice along the northeast, or ralley side, of the deposits.

The original thickness of the deposit is not known. However, it may have been in excess of 200 feet.

In the southwest face of the pit, a conspicuous limerich bed, about 6 inches thick, separates the sand and gravel beds from overlying till. The overlying till is probably younger than the till that overlies the deposits in the northeast end of the pit. The latter till is not present in the southwest face of the pit; therefore, the lime-rich bed lies unconformably on the sand and gravel beds. The lime-rich bed consists chiefly of angular gray shale fragments embedded in a calcareous clay matrix; both the shale and the clay are white when dry. Partly incorporated in the bed and extending slightly into the overlying till are cobbles and small boulders. The bed is about 7 () feet above the ralley floor, or a third of the way up the valley side, and if projected across a tributary to the south, it would coincide closely with a belt of boulders that rims the valley walls in this area and separates two differentcolored tills of probably two different substages (see description under the heading "Ground moraine"). Therefore, the collapsed stratified deposits in the pit are probably earlier than the till overlying the boulder belt and are contemporaneous with the till overlying the deposits in the northeast part of the pit. The stratified deposits apparently were overridden by the same ice sheet that deposited them, perhaps during a minor pulsation of the ice front; some of the sand and gravel beds were dragged by ice along their upper contact. The orientation of the drag folds in the sand and gravel and of lineations that consist of parting planes and thin stringers of sand and gravel in the overlying till (see fig. 9) suggest that the overriding ice at this point moved southwestward. Later, after a time interval perhaps of the duration of a substage or more, the stratified deposits and the till were overridden, and the younger till, exposed in the southwest end of the pit, was deposited. This younger till is absent from the northeast part of the pit; presumably, it has been removed by erosion. The lime-enriched bed and incorporated boulders in the southwest end of the pit probably represent a weathered remnant of the lower till. Like the younger till, the lime bed and the boulders apparently have been removed from the northeast end of the pit by erosion.

The older till is also believed to underlie the sand and gravel deposits, judged from relations shown in a road cut across the tributary to the south. In the road cut two tills are separated by a boulder belt. The lower till both underlies and overlies deformed beds of sand and gravel that are interpreted to have formed contemporaneously with the sand and gravel that underlies the till in the northeast part of the gravel pit. Although the sand and gravel beds in the road cut are but moderately tilted compared to those in the gravel pit, they probably are a part of the same deposit. Abundant shale chips in both places, as well as dendrites on the surface of the pebbles in both places, help confirm this supposition.

In summary, the deposit in the gravel pit appears to be a kame terrace that was laid down between the valley wall and ice which occupied most of the valley. When the ice in the valley melted and no longer fur- 
nished support, the deposit slid out toward the middle of the valley as solid blocks. In sliding, the beds were rotated to a slightly overturned position in the north end of the pit; rotation was less in the south end of the pit. After the beds slid, ice again adranced over the sand and gravel and deposited the till in the northeast end of the pit. That this advance occurred subsequent to collapse of the sand and gravel is indicated by the fact that the lineation in the overlying till was not destroyed. The second advance appears to have been a minor pulsation of the ice front rather than an advance of substage rank. An interval of time then followed long enough to allow considerable exosion and weathering of the till surface--that is, the boulder belt and lime-enriched bed. In a later substage, ice again advanced over the area and deposited the till that overlies the lime-enriched bed in the southwest end of the pit and that overlies the boulder bed elsewhere along the valley walls.

Similar deposits of gravel, sand, and silt are poorly exposed nearby in three other places along the valley walls of the Des Lacs River. Each deposit is moderately to intensely deformed and is overlain by a boulder belt which, in turn, is overlain by till. These exposures are too small to be shown on the map.

\section{ORIGIN AND TYPE OF DEPOSIT}

The deposits between Velva and Verendrye probably were laid down as a kame terrace or series of kame terraces that were deposited in a pre-Mankato Souris River valley somewhat wider than the present valley. The extensive deformation of beds indicates an icecontact type of deposit. Likewise, the generally poor sorting, especially of the coarser material, suggests that the material was not transported far. The fact that the deposits are present one-fourth to three-fourths of a mile up the tributaries of the main valley indicates that the former valley walls were wider than the present valley. Likewise, the fact that the base of the deposits is about one-third of the way up the present valley walls shows that the former valley was at least two-thirds the depth of the present valley.

The following hypothesis is offered to explain the origin of the deposits. A preexisting valley, as wide as the outer limits of the supposed kame terrace deposits, was overridden by ice. During deglaciation, ice perhaps remained in the valley after the main ice front had receded a short distance, to the north of the valley. Melt water from the main ice sheet then scoured a channel in the ice remaining in the valley. The melt water had one channel wall in ice and an opposite channel wall in till of the valley wall. Deposition of sand and gravel in these channels, followed by collapse as the supporting ice melted, produced kame terraces. In places, kame terraces were deposited directly opposite each other on opposite valley walls and at about the same height by different melt-water streams. That the main ice front had not receded far is indicated by the generally poor sorting of the material, suggesting transportation for only a short distance before deposition.

\section{ENGINEERING GEOLOGY}

Except where cemented with calciium carbonate or iron oxides, the deposits are highly permeable. Most parts are also highly porous, although some fine silt beds are moderately porous and the included till lenses are almost nonporous. Slopes are moderately stable on the coarser gravel and are relatively unstable on sand. Likewise, the coarse material resists gullying, but the sand erodes rapidly. When properly compacted, the deposits have generally high foundation strength. Unless washed, most of the coarser material contains too much silt and clay to be useful except for road surfacing. The sand, however, is remarkably clean.

\section{LINEAR-RIDGE DEPOSITS}

\section{NAME, LOCATION, AND AREAL EXTENT}

Remarkably straight parallel ridges trend southeasterly across the southeast part of the area. It is believed that they are drumlinoidal features formed at the base of southeastward advancing glacial ice.

The ridges in the Souris River area are restricted to the area south and southeast of Velva. Some of them extend to the southern edge of the Souris River valley, but none are present north of the river.

\section{FORM AND SIZE}

Most of the ridges in the Souris River area are 5-15 feet high, steep sided and sharp crested, and 1-3 miles long. Some are less than 5 feet high and are scarcely discernible in the field, though even the lowest is plainly visible on aerial photographs where their crests show as light-gray lines. The spacing of the ridges is varied, but generally the smaller ridges are more closely spaced, the limit being one crest in every 300 feet. In cross section, the lowest ridges have very gently sloping sides and rounded tops. The higher ridges are proportionately narrower and are therefore more conspicuous.

The longest and most conspicuous ridge extends from the south valley wall of the Souris River at the town of Verendrye, southeastward for a distance of $131 / 2$ miles. It is breached in two places near Verendrye by gaps eroded by melt water and is cut by a stream channel that probably carried melt water from an esker. The ridge decreases in height from about 50 feet at its northwest terminus to less than 5 feet near its southeast end. Throughout much of its length it is 


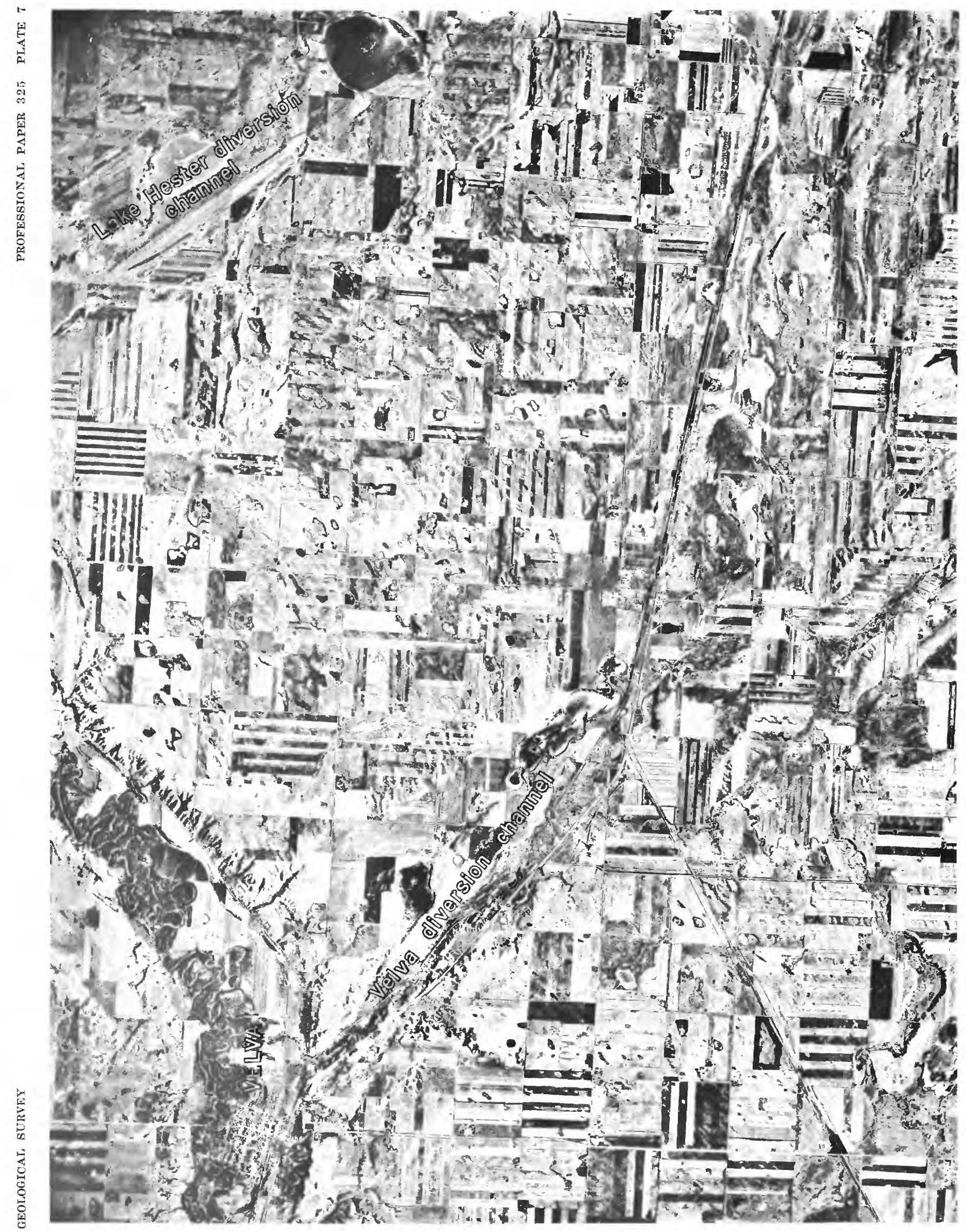




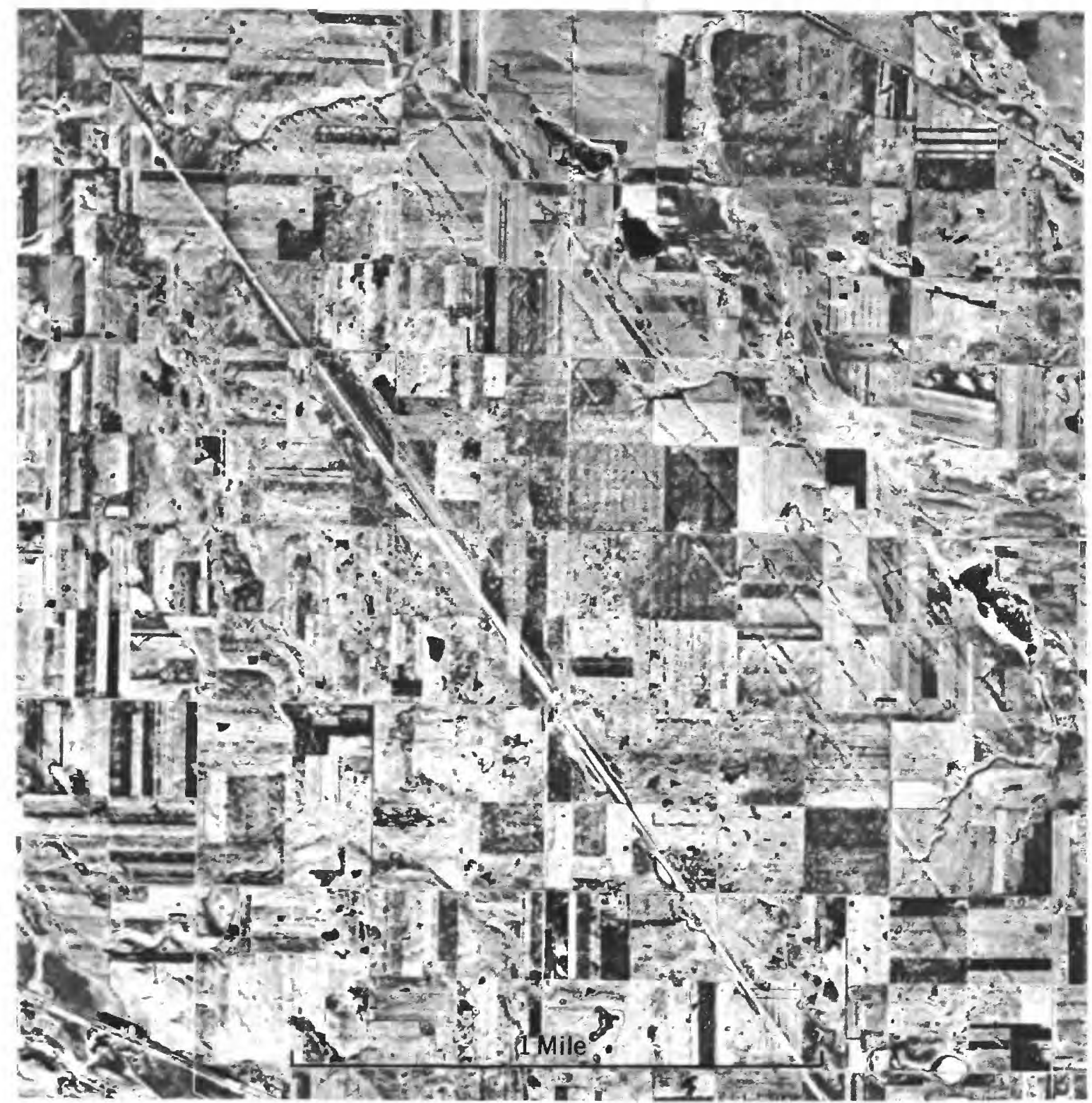

AERIAL VIEW OF LINEAR RIDGES AND GROOVES IN THE SOUTHERN PART OF MCHENRY COUNTY, N. DAK. 
about 30 feet high, even and sharp crested, and it has a remarkable symmetrical cross profile (see pl. 8). In most places its base is less than 200 feet wide. The feature resembles a large railroad or highway grade. Indeed, a segment of it was at one time used as a road; faint outlines of the road are still discernible. At the southeast end of the ridge and slightly en echelon to it is a second ridge, about $31 / 2$ miles long, which extends to a point about $1 \frac{1}{2}$ miles southeast of Balfour.

The highest ridge in the area occupies the middle part of the Lake Hester diversion channel in sec. 10, T. $153 \mathrm{~N}$., R. $79 \mathrm{~W}$. It is parallel to the trend of the channel and is about 60 feet high at its northwest end. Southeastward, it diminishes to about 30 feet in height in a distance of slightly less than 1 mile, beyond where it is breached by melt water that flowed down the diversion channel (see pl. 7). An even-crested segment southeast of the breach is nearly 2 miles long. Several other random-spaced notches, $5-15$ feet deep, break the otherwise fairly even crestline.

Most of the ridges trend about S. $50^{\circ}$ E. Only a few vary slightly along their courses. An individual ridge commonly tapers to extinction along its trend, but there is commonly another ridge collinear with it or parallel to it in en echelon fashion.

Shallow linear grooves in the surface of the ground moraine are parallel to the linear ridges. Also in the same area there are a series of small arcuate recessional moraines that lie transverse to the linear ridges and grooves. These grooves and recessional moraines have already been discussed under the heading "Ground moraine."

There are long, narrow linear ridges and grooves in central North Dakota east of the Souris River area. Many of these are shown in plate 15. Most of these ridges are more indistinct than in the area southeast of Velva, but otherwise they are similar in appearance. Their internal composition and structure are not known, though till apparently forms most of their crests and flanks. Those that were formed by the Leeds lobe (see pl. 15) trend mostly southwest. Lobate recessional "washboard" moraines lie transverse to the linear ridges and thereby suggest a relation between the two features.

\section{STRATIGRAPHIC POSITION AND AGE}

In most places linear-ridge deposits are overlain by no other deposits, although in a few places they are overlapped by diversion-channel deposits and by arcuate recessional moraines. About a mile southeast of Verendrye, two of the larger arcuate ridges appear to extend up onto the flanks of a large linear ridge in that area; others may do so near Balfour. The arcu- ate ridges are of such low relief that ground views are of little value in determining accurately the stratigraphic relations of the two types of features. Aerial photos show the features much better than they can be observed on the ground, but the use of aerial photos to determine the stratigraphic relations is also not entirely conclusive.

In most places the deposits are underlain by till, but in some places they are underlain by sand that probably is different in origin from the ridges. The ridges in the mapped area are confined mostly to the area underlain by the Cannonball member of the Fort Union formation, although similar ridges are underlain by other strata outside of the area. Bedrock extends locally up into a few ridges. One such relation is exposed in a road cut in the southeast part of McFenry County, in the NW1/4 sec. 5, T. 152 N., R. 77 W., where $\check{5}$ feet of tilted Cannonball strata are exposed. The bedrock in this exposure is sandstone and clayey shale and strikes parallel to the trend of the ridge; on the northeast flank of the ridge it dips 15-30 degrees northeast. Bedrock in the southwest flank of the ridge was not sufficiently exposed to determine its attitude accurately, but it probably dips southwest. The dip of the beds is probably due to ice shove.

The linear ridges were formed by the last ice to cover the area. They clearly antedate the diversionchannel deposits of that area because they were breached in places by the melt waters of these channels. They are older than the river-terrace deposits in the vicinity, because the stream that deposited the terraces truncated the large linear ridge at the head of the Lake Hester channel. The long linear ridge that extends from Verendrye to near Balfour is probably older than an esker to the southwest, because the linear ridge is crossed by a stream channel that probably carried melt water from the esker.

\section{GRAIN SIZE SHAPE, AND LITHOLOGIC COMPOSITION}

The larger ridges consist predominantly of stratified sand and incorporated irregular bodies of till. Till commonly forms the flanks of these ridges and the upper few feet of the crests. Some ridges locally contain fine gravel. A gravel pit 10 feet deep in the crest of a ridge in the $\mathrm{NE} 1 / 4$ sec. $15, \mathrm{~T} .152 \mathrm{~N}$., R. $77 \mathrm{~W}$., exposes moderately well sorted coarse sand and fine gravel. It is the thickest known section of gravel free of till or silt lenses. Silt usually is a minor constituent, although, in a few deposits, lenses of silt are fairly abundant.

Most of the sand is fine to medium grained and consists chiefly of angular quartz fragments. The intercalated till bodies range in length mostly from 2 to 
10 feet. Most are irregular blobs whose longest dimension is essentially horizontal. In places, though, tongues of till extend into the sand deposits.

Ridges less than 5 feet high consist chiefly of till. Neither pebble-orientation studies nor laboratory work was done on this material, but it resembles superficially the till of the adjacent ground moraine. In contrast, irregular bodies of till in the sand of the larger ridges vary widely in grain size-from compact clayey till, similar to the ground moraine, to a predominantly sandy till that contains just enough clay to bind it. In places, the more sandy component has an indistinct fissility.

Because the linear ridges are unusual in form and composition and their origin is uncertain, a fairly large number of auger holes were drilled. Figure 10 is a cross section, reconstructed from 11 auger holes drilled across the most conspicuous ridge between Verendrye and Balfour. It could not be determined from drilling whether there is a sharp contact between the upper buff sand and the lower grayish-brown sand, or whether there was a gradational color change that marks an upper oxidized sand from a lower unoxidized sand. However, the two different-colored sands were probably deposited separately. The exact depth to bedrock in auger hole 7 could not be determined with certainty, but the interpretation is probably accurate to within 10 feet. The other contacts are believed to be accurate to within a couple of feet.

An auger hole was drilled on the same ridge in the $\mathrm{NE} 1 / 4$ sec. $11, \mathrm{~T}$. $152 \mathrm{~N}$., R. $78 \mathrm{~W}$., where the ridge is 12 feet high. The top of the hole was in a road cut 7 feet below the crest of the ridge. Between the crest of the ridge and the top of the hole were lenticular sands and fine gravels containing a few lenses of till 3-5 feet long and 1-3 feet wide. The long axes of most of the stratified and unstratified lenses were parallel to the trend of the ridge. The following material, which is fairly typical of material found in numerous other holes augered in the linear ridges, was penetrated in the auger hole: tered at 65 feet

\section{Material}

Sand. tan, medium to coarse, clean : pebbles as much as one-fourth inch long: water starts at about 15 feet Till, unoxidized, bluish-gray

Sand, gray. medium-grained; some till lenses: something hard encountered at about 36 feet

Sand, grayish-blue; believed to consist largely of material derived from Cannonball strata and may include weathered top of that formation: hard layer encoun-

Cannonball member of the Fort Union formation, green sand and chocolate-brown silty clay

Thickness (feet)

30. 0 2. 0 4. 5

Total material penetrated in auger hole
BEDDING AND SORTING

The stratified parts of the deposits are generally poorly bedded but are moderately well to well sorted. Most of the sand is fairly uniform in size. The silt is thinly laminated. In the few places where gravel is exposed, it is poorly bedded. Many of the till lenses in the sand contain less clay than the nearby till of the ground moraine. Some till lenses consist almost entirely of silt and sand with just enough clay to bind them together.

\section{INDURATION, CEMENTATION, AND WEATHERING}

Induration and cementation are negligible. Where till forms the upper surface, the deposits are slightly cemented by caliche in the lime-enriched horizon of the soil. On aerial photographs this lime-enriched zone shows clearly as a grayish-white line on the crests of ridges where the upper part of the soil cover is removed by erosion. Therefore, ridges less than 3 feet high are plainly visible on the photographs although they are distinguished with difficulty on the ground.

Both the stratified material and the till are oxidized down to the water table. The oxidized material is usually tan, whereas the unoxidized sand is generally gray and the till is gray to bluish gray.

\section{ORIGIN AND TYPE OF DEPOSIT}

It is believed that the linear ridges are long narrow drumlins that were formed on a drumlinized till plain during a southeast advance of the last ice lobe that occupied the area. However, it is not clear whether parts of the ridges consist of material that was deposited by the last ice sheet, or whether they represent preexisting deposits that were eroded and shaped by the ice. This problem is discussed in more detail below.

Before the internal composition, depth to bedrock, relation to transverse arcuate recessional moraines, and other stratigraphic relations of the ridges were well known, the writer and others favored the hypothesis that the linear ridges were crevasse fillings (Lemke, Jensen, Smith, 1951, p. 1460; Lemke, 1953, Geol. Quad. maps). Reasons for believing that the linear ridges are not crevasse fillings, as formerly supposed, are summarized as follows:

1. There is no mechanism known to the writer for controlling fracturing in the ice that would result in such long parallel crevasses as would be necessary to account for this type of origin. Augering in and through the deposits has demonstrated that in most places a thick blanket of till lies between the linearridge deposits and bedrock. Therefore, fracturing in the ice could probably not be controlled by any type 


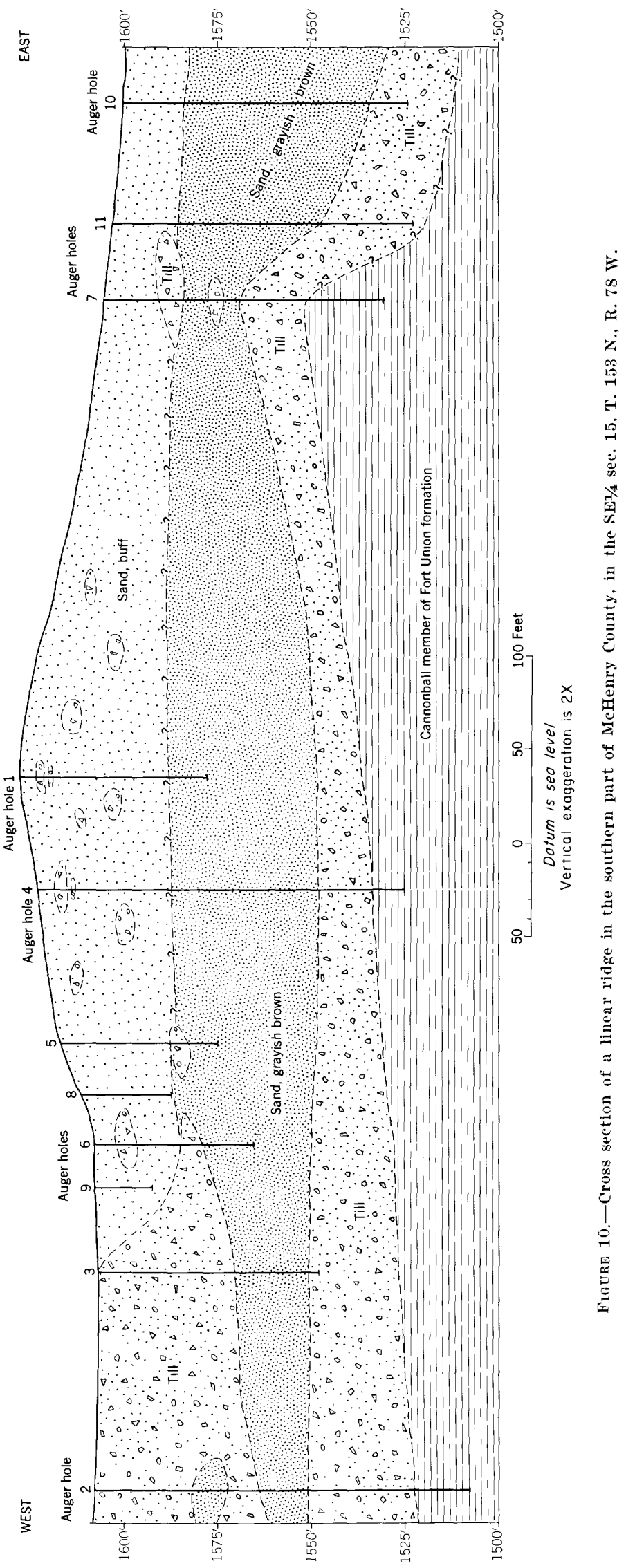


of structure or transmitted stress in the underlying bedrock.

2. Although the internal composition of the larger ridges is what one might expect to find in crevasse fillings, it is not evident how till could form the crests and flanks of such features. Why the smaller ridges consist entirely of till would also have to be explained.

3 . It is more than coincidental that the recessional "washboard" moraines lie transverse to the linear ridges. This is indicated by the fact that they are transverse both to the southeast-trending linear ridges southeast of Velva and to the southwest-trending ridges east of the Souris River area (see pl. 15). Thus, a relation is implied. Inasmuch as we know that the transverse ridges mark successive pauses of the retreating ice front, one may then at least suspect that the linear ridges are also related to ice movement. Also, because the recessional moraines indicate the direction of ice retreat, it follows that the linear ridges, to be crevasse fillings, must have all been formed parallel to the direction of ice movement. Although crevasses parallel to the direction of ice movement are common, the writer knows of no place where they are not associated also with crevasses parallel to the ice front. There are no such resulting ridges in the Souris River area.

In shape and in their relation to other features, the linear ridges in the Souris River area resemble, in some respects, features described by Gilbert (1904, p. 77-78), Alden (1905, p. 17), Grant and Higgins (1913, p. 66), Ray (1935, p. 310-311), Armstrong and Tipper (1948, p. 287-293), Smith (1948, p. 503-513), Hage (1945, p. 24-26), Deane (1950, p. 12-13), Chapman and Putman (1951, p. 166, 199), Dyson (1952, p. 204 211), and other individuals. Other similar features have been observed jointly by Roger B. Colton, Robert $\mathrm{M}$. Lind vall, and the writer.

Although many of the features described in the literature are similar in shape and in relation of associated features to the linear ridges in the Souris River area, most if not all of them consist of unstratified drift. In contrast, the larger ridges in the Souris River area consist in part of stratified material. Moreover, they differ from features described by Dyson and others in that they apparently were not deposited in ice tumnels in the lee of bedrock obstructions. Although three segments of end moraines north of the Souris River appear to have buried knobs of bedrock, these knobs could not have acted as buttresses for forming each individual ridge in the Velva area; the closest ends of some ridges are more than 10 miles south of the end moraines. An auger hole, drilled in the northwest end of the large ridge at the head of the Lake
Hester diversion channel, showed that the bedrock surface was no higher under the ridge than under the surrounding terrain. The northwest end of the long ridge at the top of the Souris River valley wall near Verendrye consists chiefly of sand and gravel, though it rests directly on bedrock. Even if an obstruction such as a bedrock knob or preexisting frozen till had been present, it would not be possible for any parts of the ridge that was formed in the resulting ice tunnel to contain stratified material solely by till being squeezed into the tunnel from unfrozen drift at the base of the ice as described by Dyson $(1952$, p. 204 211). However, this might be possible if the tunnels formed in the lee of the obstruction were filled in part by till squeezed into the tunnel from its base, walls, and top, and in part by outwash carried by melt water streams that were using the tunnel.

Partly stratified drumlins are not rare. As pointed out by Gravenor (1953, p. 676), stratified materials have been noted in many drumlins in both North America and Europe. Most such drumlins, however, are asymmetrical in longitudinal profile, oval in plan, and steeper and wider at the stoss end than at the gently sloping and tapering lee end. Their lengths rarely exceed five times their widths and generally are considerably less.

A few drumlins of this type are in Barnes County, N. Dak., in areas a few miles northeast and southeast of Valley City. Their core consists of stratified deposits; their crests and flanks, of till. They trend southwest and appear to have been formed by ice advancing over stratified ice-contact deposits.

As pointed out by Gravenor (1953, p. 674-681), drumlins can be formed as follows:

1. Masses of till and stratified materials would be deposited at the front of an advancing glacier if there was a temporary halt during the ice advance.

2. Ice riding over this drift would erode and shape it and thereby produce drumlins.

According to this theory, both erosion and shaping of existing deposits occurs. Hence, any thin stratified deposits that might be present on the surface would be preserved only where these deposits were moulded into ridges.

Gravenor's theory effectively reconciles previous differences of opinion, expressed in the literature, as to whether drumlins are depositional or erosional features. Specifically, it offers an explanation for the presence of stratified material in drumlins of typical shape. But whether the theory is applicable to the origin of the long and narrow linear ridges in the Souris River area, is open to question. Assuming that there was stratified drift in front of the last advancing ice sheet that cov- 
ered the Velva area, the question arises whether stratification in outwash along the trend of such a long and narrow ridge would be preserved during the time the ridge was being formed in part by moulding, and in part by erosion. Also to be explained is why the areas between the ridges consist of till that is identical to the ground moraine in areas where there are no ridges, rather than stratified deposits like those in the ridges. If stratified outwash had been overridden by the ice, some remnants of it would probably be preserved in the intervening areas between the ridges. Moreover, why do the small ridges consist almost entirely of till? Also, how could the till and stratified deposits of the ridges become so intertongued and otherwise intimately related without destroying the stratification of the bedded deposits, unless bodies of till were incorporated during original deposition of the outwash? It would then have to be assumed that the ridges were almost entirely erosional, that there was very little remoulding of their form, and that the material between the ridges was completely removed down to the present level of the groundmoraine surface.

Unexplained by Gravenor's hypothesis is the origin of the linear grooves parallel to the linear ridges. One might postulate that this grooving could take place simultaneously with the removal of the rest of the material between the ridges. One would raise the question, however, why erosion took place down to one level, producing the present ground-moraine surface, and then continued, here and there grooving the surface further to a rather uniform depth.

In summary, it appears that the linear ridges are drumlinoidal features formed during a southeast ad. vance of the last ice sheet to occupy the area. However, it is not clear whether parts of the ridges consist of material deposited by the last ice sheet or whether they represent preexisting deposits that were eroded and shaped by the ice.

\section{ENGINEERING GEOLOGY}

Natural slopes of the deposits are well drained. Permeability is high in the sandy parts of the deposits but is low in the till parts. Cut slopes have low stability in sandy parts of the deposit but are highly stable in till-rich parts. Natural slopes of all parts of the deposits are essentially uneroded.

The deposits probably would compact fairly well with roller equipment and would have high foundation strength. All parts of the deposits can be easily excavated with power equipment. Except for a few small areas of gravel, the deposits are unsuited for construction material other than for subgrade in roads.

\section{DIVERSION-CHANNEL DEPOSITS}

NAME, LOCATION, AND AREAL EXTENT

Deposits in channels formed chiefly by melt water that was diverted out of the valleys of the Souris and Des Lacs Rivers are termed diversion-channel deposits. Most are probably graded to terrace surfaces along the valley walls of the two rivers and their melt waters emptied into glacial Lake Souris. In places the diversion-channel deposits were ice marginal, but they differ sufficiently from other deposits mapped as "icemarginal out wash-channel deposits"-in grain size and thickness, in relation to other deposits, and in originto be mapped separately.

Three large diversion channels head at the south edge of the Souris River valley between Velva and Verendrye in McHenry county. The first-formed of these heads at Velva and trends southeast toward the south end of glacial Lake Souris; this channel is designated the Velva diversion channel (see pl. 15). The secondformed diversion channel, the Lake Hester diversion channel, heads about 5 miles farther down the Souris River valley. It joins the Velva diversion channel near Bergen. The third diversion channel formed in this area heads at Verendrye and is referred to as the Verendrye diversion channel. It joins the combined channel of the other two diversion channels about 5 miles southeast of Balfour. Below this point the channel system divides into several branches.

Between Minot and Sawyer in Ward County, glacial melt water, meandering across the present valley of the Souris River, left three high channel remnants that do not coincide with the present valley. Two of these are on the north side of the valley and one is on the south side. All three are carved in ground moraine.

When a part of the Souris River in Saskatchewan, about 5 miles north of the International Boundary, was still blocked by ice, water was diverted through a broad shallow trench (see pl. 1, inset) into the valley of the Des Lacs River, and a high-stage diversion channel was cut (Lemke and Kaye, 1953). Remnants of this diversion channel are preserved on both sides of the valley of the Des Lacs River, between the International Boundary and Kenmare.

Diversion-channel deposits are more extensive than any other glaciofluvial deposits except the ice-marginal outwash-channel deposits. They are generally $1 / 2-2$ miles wide and are thus wider than most of the icemarginal outwash-channel deposits. They are as long as many of the latter deposits but are not as numerous. An especially large expanse of nearly continuous deposits in the Verendrye diversion channel north of Karlss'uhe covers an area $3-4$ miles wide and about 7 miles long. 


\section{TOPOGRAPHY}

The relatively flat floors of the channels are generally 15-30 feet lower than the surrounding ground-moraine, plain. In places, the walls of the channels are fairly distinct, but in many places they are so low in comparison to the width of the chamel that they are difficult to distinguish visually. On aerial photographs however, the deposits are easily differentiated from the surrounding ground moraine by a marked contrast in tone and texture.

Circular kettles with abrupt sides 10-20 feet deep are fairly abundant in the otherwise nearly flat floors of the diversion channels. Many of these contain ponds. Linear-ridge deposits are present in the middle of some channels. Postglacial V-shaped tributaries have been incised in the head of the Velva and the Lake Hester diversion channels. Intermittent streams in these tributaries flow north to the river, a direction opposite from the one in which the glacial melt water flowed.

A comparison of the altitudes of the floors of the diversion channels indicate the order of succession that melt water flowed down each channel. It also shows the gradient of each chammel, which, when compared with the grain size and width of the deposits, gives some indication of the volume of water that flowed down the channels.

The floor of the Velva diversion channel, at its head, is at an altitude of about 1,590 feet, that of the Lake Hester diversion channel is about 1,575 feet, and that of the Verendrye diversion channel about 1,555 feet. The gradient of the segment of the Velva diversion channel between its head and its confluence with the Lake Hester diversion channel is about 3 feet per mile. The gradient of the floor of the Lake Hester diversion channel is about the same, whereas the gradient of the first few miles of the Verendrye diversion chamnel is somewhat less.

The floor of the remnant of the diversion channel about 1 mile northwest of Sawyer (see pl. 1), is at an altitude of about 1,585 feet. The remnant farther upstream and also on the north side of the river is at an average altitude of about 1,590 feet. The floor of the remnant on the south side of the river is at an altitude of about 1,670 feet.

The high-stage diversion channel between the International Boundary and Kenmare is about 2 miles wide on the west side of the inner valley of the Des Lacs River and less than 1 mile wide east of the valley. It diminishes in width to the south, and about 10 miles south of the International Boundary it occurs only as isolated benches along the valley walls. Several discontinuous but fairly distinct scarps separate cut terraces that occur on the west side of the valley. The highest of the terraces is at an altitude of about 1,850 feet, the lowest is at about 1,810 feet, or about 30 feet above the present river level. The surface of each terrace is pitted by interconnected, elongated, shallow fluvial-scour depressions.

\section{THICKNESS}

The thickest deposits of the Velva, Lake Hester, and Verendrye diversion channels are generally near the heads of the channels. Channel deposits 27 feet thick are exposed in a highway cut in the Velva diversion channel, one-half mile southeast of Velva. Deposits a few miles downstream in the vicinity of Voltaire generally range in thickness from 15 to 20 feet, though water-well data indicate that they may be considerably thicker locally. The maximum thickness of outwash near the head of the Lake Hester diversion channel is about 15 feet, but in most places the outwash is 5 feet thick, and, in places, there is only a thin veneer. Near the head of the Verendrye diversion channel, the outwash is 20-25 feet thick. In the large Great Northern Railway gravel pit about 2 miles southeast of Verendrye, outwash is at least 17 feet thick. Farther down the channel, it is considerably thinner.

In the diversion channel remnant north of Sawyer, the outwash is generally less than 15 feet thick; in the other two diversion channel remnants in the area, it exceeds 5 feet only locally.

The deposits in the high-stage diversion channel north of Kenmare are thin and patchy, and in places till is at the surface, but because of the difficulty of delimiting the small patches of outwash, the entire surface of the channel remmants is shown as underlain by diversion-channel deposits.

\section{STRATIGRAPHIC POSITION AND AGE}

The diversion channels and their deposits date from the deglaciation of the last ice sheet that covered the area. No younger glacial deposits overlie the deposits except where they are overlapped locally by river-terrace deposits. In a few places, recent slope wash veneers the channel walls, and thin alluvium covers the floors; in a few other places, narrow channels of intermittent Recent streams cross the floors of the channels; in most places, the resulting younger deposits have not been differentiated from the diversion-channel deposits.

In some places, the deposits rest on bedrock; in other places, they rest on till. Near the heads of the Velva, Lake Hester, and Verendrye diversion channels, they rest partly on till and partly on bedrock. A narrow postglacial tributary of the Souris River incised in the floor of the Lake Hester diversion channel exposes 
bedrock in several places at depths of 5-10 feet. Where bedrock is in contact with the deposits, it is either the basal few feet of the Tongue River member of the Fort Union formation or the upper few feet of the Cannonball member of that formation. Farther downstream in these channels, the deposits are almost everywhere underlain by till. Till underlies the diversion channel remnants between Sawyer and Minot and the remnants north of Kenmare.

\section{GRAIN SIZE, SHAPE, AND LITHOLOGIC COMPOSITION}

Sand and gravel are the chief constituents of the deposits at the heads of the Velva and Lake Hester diversion channels, though some cobbles are present. Near the head of the Velva diversion channel, most of the gravel is fine to medium. Farther down the channel past Voltaire, coarse sand and silt predominate. In general, the deposits in the Lake Hester diversion channel are finer than those in the Velva diversion channel. Near the head of the Lake Hester diversion channel, fine gravel predominates; in less than 1 mile down the channel, the grain size decreases to that of coarse to fine sand, which, in turn, grades into fine sand and silt farther southeast.

The average size of material in the Verendrye diversion channel is finer than in the two channels just described. Coarse sand and fine gravel predominate from the head of the channel to the vicinity of Karlsruhe. From Karlsruhe southeastward to where the channel divides into several branches, sand, silt, and lesser amounts of clay are the chief constituents.

Sand and fine to medium gravel predominate in the diversion channel remnants between Sawyer and Minot. The patchy deposits north of Kenmare consists chiefly of fine gravel, sand, and silt, but boulders concentrated by fluvial erosion of the till are abundant on parts of the channel floor where other deposits are very thin or absent.

Gravel is subrounded to subangular. Angularity increases somewhat with decrease in grain size. Many of the larger rocks are striated or flattened on one or more sides by glacial abrasion. Some quartzites exhibit percussion marks.

Carbonate rocks predominate in the gravel size fraction; granitic rocks are next in abundance. The sand fraction consists chiefly of quartz, with some feldspar and limestone grains. Small chips of lignite are intermixed with the sand.

\section{BEDDING AND SORTING}

In most places, the deposits are well bedded and well sorted; in places, as near the heads of chamnels, they show distinct crossbedding. Beds range in thickness from a few inches to 3 feet. Sorting, in general, is more pronounced than in any of the other glacial deposits except the lake deposits. The material in the three main diversion channels between Velva and Verendrye grades from fine to medium gravel near the heads of the channels to sand and silt a few miles downstream. In any one place in these channels, therefore, there is a small size range. Sorting is less evident in the rest of the diversion channels but even in these channels the deposits are fairly well sorted.

\section{INDURATION, CEMENTATION, AND WEATHERING}

An immature soil 2 or 3 feet thick has formed in the upper part of the gravel. In the upper foot or two, carbonate rocks are partly to completely leached out; the few that remain are etched or decomposed. Biotiterich granite and gneiss have been mechanically disintegrated by hydration of the biotite though the feldspar remains fresh and unaltered.

Calcium carbonate leached from limestone has migrated downward to a depth of 1-3 feet, where it is concentrated as caliche in the C horizon of the soil. Some calcium carbonate may also have traveled upward from depth by capillary action during dry periods. Most of the caliche encrusts the undersides of pebbles, especially flat pebbles, where it may be an eighth of an inch thick. In places it cements the $\mathrm{C}$ horizon into a loose conglomerate.

\section{ORIGIN, TYPE OF DEPOSIT, AND GEOLOGIC HISTORY}

Water flowing down the valleys of the Souris and Des Lacs Rivers was diverted out of these valleys by glacier ice in several places: between the International Boundary and Kenmare, between Minot and Sawyer, and between Velva and Verendrye. This water, together with some melt water flowing directly off the ice, carved broad diversion channels, along the floors of which were deposited gravel, sand, and minor amounts of silt and clay.

The high-stage diversion channel between the International Boundary and Kenmare came into existence while a part of the Souris River valley in Canada was blocked by ice. At that time water in the Souris River valley was diverted through a shallow sag (see plate 1) into the valley of the Des Lacs River. The probable source of this water and the relation of this diversion channel to the diversion channels farther downstream are discussed in the section "Summary of geologic history."

Melt waters that meandered over the present valley of the Souris River between Minot and Sawyer left three high-level remmants of diversion channels.

Melt waters first carved a diversion channel 3 miles long around an ice-blocked part of the valley just east 
of Minot. The altitude of the floor of this channel is about 1,590 feet. At this time, melt waters draining off ice a short distance to the northeast emptied into the diversion channel through ice-marginal outwash channels; thus the deposits of the diversion channel are gradational with the ice-marginal outwash channels in that area. Likewise, a somewhat arbitrary contact must be drawn between the diversion-channel deposits and river-terrace deposits in that vicinity, because of the gradation from one to the other. As the ice block melted from the valley, the melt waters abandoned the diversion channel and water flowed directly down the valley. Temporarily, the water made a broad bend and lapped up onto the slope of the abandoned diversion channel. As downeutting continued, the water occupied successively lower positions on the flank of the diversion channel and on the valley wall, and as a result, the area covered by melt waters in secs. 20,21 , 22, 28, and 29, T. 155 N., R. 82 W. slopes gently down to the alluvial floor of the valley from an altitude of about 1,620 feet to about 1,550 feet. The contact between diversion-channel deposits and river-terrace deposits is drawn at an altitude of 1,590 feet, which is the lowest height of the diversion-channel floor.

The channel remnant north of Sawyer has a floor altitude of about 1,585 feet and is probably contemporaneous with the channel just described. The melt waters from these two channels might have drained through the Velva diversion channel during the early life of these two channels, but the floor of the Velva diversion channel is a few feet too high to have permitted this during the later stages. The water could, however, have drained down either the Lake Hester diversion channel or the Verendrye diversion channel.

The floor of the diversion-channel remnant on the south side of the valley between Minot and Sawyer is at an altitude of about 1,665 feet and, therefore, does not appear to be contemporaneous with any of the three main diversion channels downstream. Its history is not clear. The Velva, Lake Hester, and Verendrye diversion channels, between Velva and Verendrye, successively drained the diverted melt water southeastward into the southern part of glacial Lake Souris. Spillways leading from this part of the lake carried the waters onward - at first, into the James River and southward, across the present drainage divide; later, into the Sheyenne River, which emptied into glacial Lake Agassiz.

The Velva diversion channel, which was marginal to the southwest side of the retreating ice lobe, was the first of the three channels to be incised by the melt waters. The altitude of the floor of this channel near its head is about 1,590 feet. As deglaciation proceeded, uncovering lower ground, this channel was abandoned in favor of the Lake Hester diversion channel, whose floor near its head is at an altitude of about 1,575 feet. Upon further melting of the ice sheet, this channel in turn was abandoned in favor of the Verendrye diversion channel, whose floor altitude, at its head, is about 1,555 feet. All three channels join downstream. Water from these channels drained into the southern part of glacial Lake Souris - at first, presumably through the Aylmer diversion channel; later, through the Antelope Valley diversion channel (see pl. 15). In the final stages of this diversion, the melt waters that flowed in the Verendrye diversion channel drained into the lake through a broad trough about 5 miles east of Karlsruhe. Still later, the Verendrye diversion channel was abandoned and the melt waters flowed down the Souris River valley directly into the lake at a point about 7 miles northeast of Verendrye.

\section{ENGINEERING GEOLOGY}

Permeablity is high in all but the silty and clayey parts of the deposits, and leakage problems may arise in canals or dams constructed in these deposits. Drainage is poor to moderate, owing to the generally impervious material beneath the deposits and in the channel walls. Small springs issue from several points where the valley wall of the Souris River bevels the head of the Verendrye diversion channel. The flow is small because the gradient of the channel floor is southeast away from the valley wall. Seeps are common between Minot and Sawyer, where diversion channel remnants are truncated by the river valley wall. Poorly drained segments of the channel floors contain swamps and small lakes.

Road cuts in sand and silt are subject to slumping and rapid gullying; cuts in the coarser gravel are fairly stable. The gravel makes good road beds of high foundation strength.

There is little material in the deposits that is deleterious either physically or chemically when incorporated in cement. Caliche is confined generally to the upper 5 feet or less of the deposits. Biotite-rich gneissic rocks are subject to disintegration, but the quantity of these rocks probably is not great. Lignite chips are usually small; only locally do they constitute more than a very small percentage of the deposits. Till balls, schistose rocks, platy sandstones, agate, and chert occur only rarely, or not at all, in most parts of the deposits. In general, the physical characteristics that are pertinent to construction are similar or identical to those of the river-terrace deposits. 


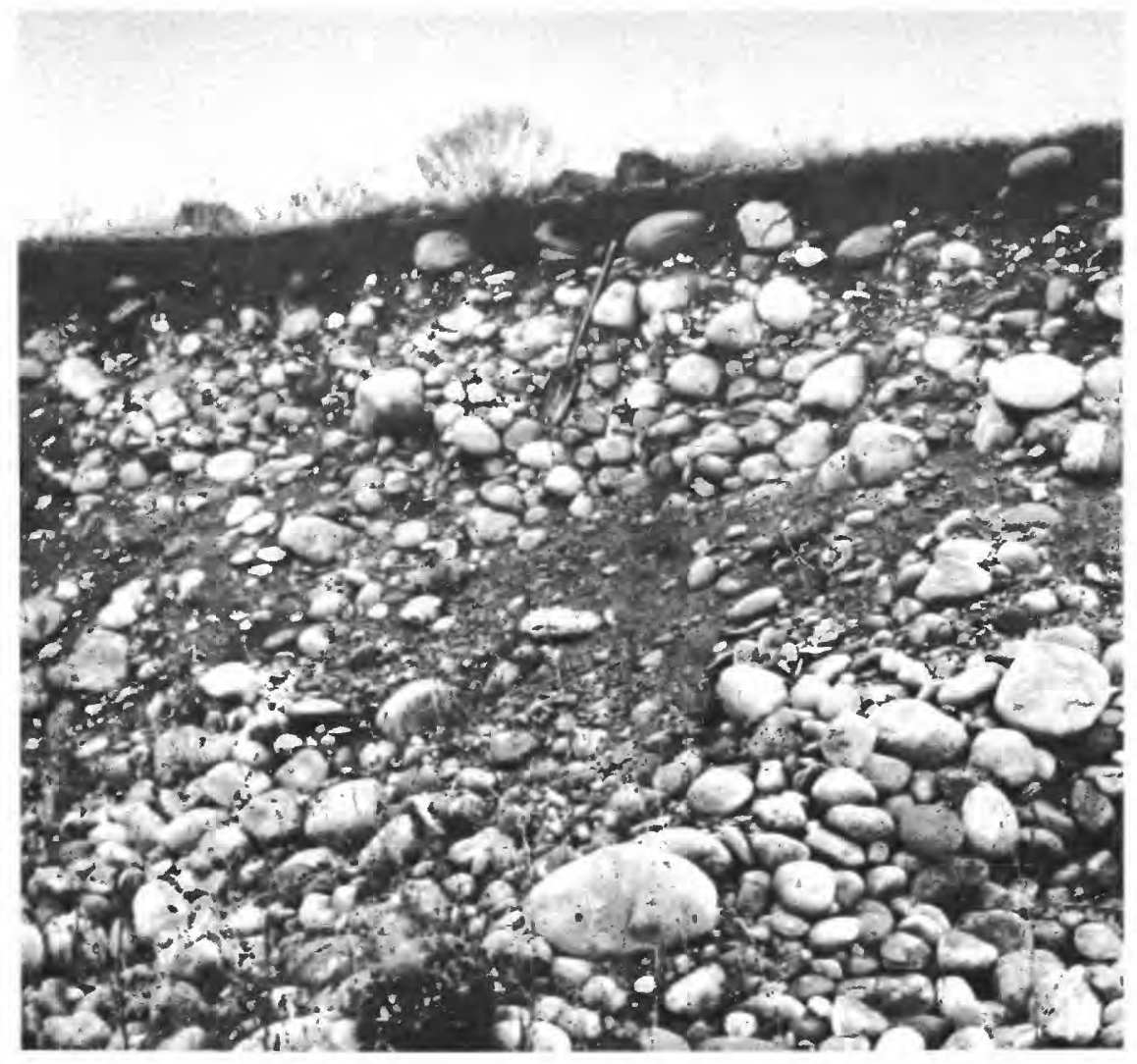

A. VIEW OF A TERRACE DEPOSIT NEAR GREENE, N. DAK., IN THE NE $1 / 4$ SEC. 10, T. 159 N., R. 85 W., SHOWING WELL-ROUNDED COARSE GRAVEL IN A PIT IN THE VALLEY OF THE SOURIS RIVER

The shovel handle is 2 feet long.

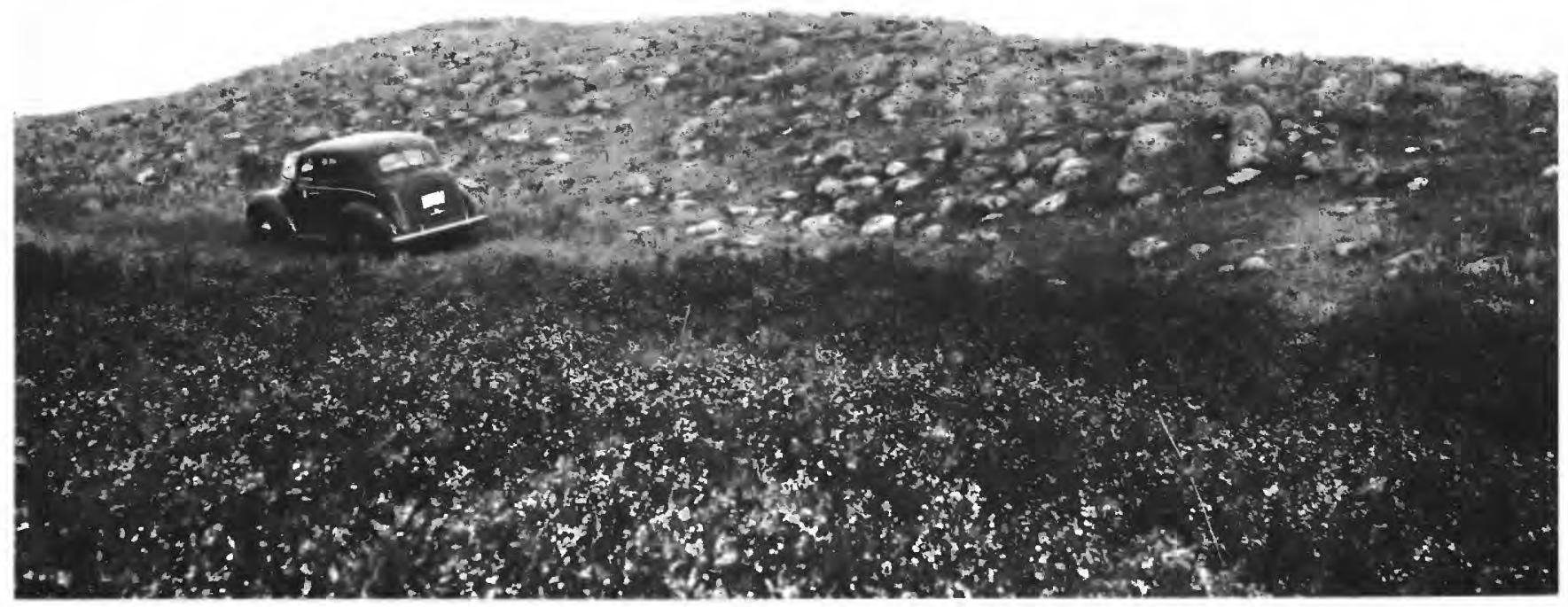

B. VIEW OF A TERRACE DEPOSIT IN WARD COUNTY, N. DAK., IN THE SE $1 / 4$ SEC. 22 , T. 157 N., R. 85 W., SHOWING BOULDER-STUDDED SURFACE The fine materials have been removed by later glacial melt waters. 


\section{RIVER-TERRACE DEPOSITS}

NAME, LOCATION, AND AREAL EXTENT

Numerous terrace remnants remain along the valley walls of the Des Lacs River. Along the Souris River valley they are confined to a segment of the valley upstream from a point a few miles below Verendrye.

Individual deposits range in areal extent from less than one-half mile long and a few hundred feet wide to deposits that are as much as 6 miles long and more than 1 mile wide. The largest ones are concentrated in the segment of the Souris valley between Verendrye and the confluence of the Souris River with the Des Lacs River.

\section{TOPOGRAPHY}

Terrace surfaces range in altitude from about 1,880 feet along the upper reaches of the Des Lacs River to about 1,470 feet a few miles below Verendrye. The highest terrace level in the Souris River Valley has an altitude of approximately 1,680 feet at the International Boundary. In most places only one level is present, but in a few places two and even three levels are separated by distinct scarps. The terrace surfaces range in height from a few feet to as much as 100 feet or more above the flood plain. Some surfaces are near the top of the valley walls, but most extend less than one-third of the way up from the floor. Some surfaces are nearly flat, but most slope gently downstream and also slope more steeply toward the middle of the valley. Because of the short lengths of most terrace remnants and local inequalities of their surfaces, it is difficult to determine acurately their downstream gradients. The terraces between Velva and Verendrye are easiest to measure; their gradients do not exceed 5 feet per mile and may be considerably less. The terrace surfaces near Minot show no gradient on topographic sheets on which the contour interval is 5 feet; their gradients are probably less than 3 feet per mile. The gradients of the terrace surfaces are greater along the valley of the Des Lacs River than along the valley of the Souris River.

The true valleyward slopes are not readily determined because the inner edge of some terraces is mantled by alluvial and colluvial fans. Some surfaces that are 30-50 feet above the valley floor at their inner edges merge with the alluvial floor at their outer edges. More commonly, however, a moderate to abrupt scarp marks the outer edge of the terrace.

\section{THICKNESS}

The deposits range considerably in thickness and there is little or no correlation between height above flood plain and thickness. They range in thickness from a thin veneer of pebbles to a known exposed thickness of 50 feet in the Minot Sand and Gravel Co. pit about 2 miles west of Minot, in the NW1/4 sec. 21, T. 155 N., R. $83 \mathrm{~W}$.; but more commonly they are 5-20 feet thick. In some places gravel was not deposited and the preexisting till is exposed at the surface; because of the difficulty of delimiting these small patches they have not been differentiated from the terrace deposits.

\section{STRATIGRAPHIC POSITION AND AGE}

In most places, the deposits rest on till. In a few places, such as parts of a terrace in McHenry County, in sec. 33, T. 154 N., R. 79 W., and sec. 5, T. 153 N., R. $79 \mathrm{~W}$., the deposits rest on bedrock. Except for the alluvial and colluvial fans already mentioned, no younger deposits overlie the unit.

All terrace deposits were laid down by glacial melt waters during deglaciation of the last ice sheet that covered the area. Some deposits were laid down probably at some distance from the ice front; other deposits, probably near the ice front.

\section{GRAIN SIZE, SHAPE, AND LITHOLOGIC COMPOSITION}

The deposits range in grain size from silt through boulder, but sand and gravel size fractions predominate. Average grain size also differs greatly between deposits.

The terrace deposits along the upper reaches of the Souris River valley, in Renville County in the vicinity of Greene (pl. 9.4), contain the coarsest material by percentage volume, but other terraces contain larger individual rocks. The average grain size in a gravel pit 4 miles southeast of Greene, in sec. 3, T. 159 N., R. $85 \mathrm{~W}$., operated by the .J. L. Shiely Company for aggregate for the Garrison Dam, N. Dak., probably is coarser than any other terrace deposit in the mapped area. A sieve analysis of a typical sample from this deposit showed the following size fractions:

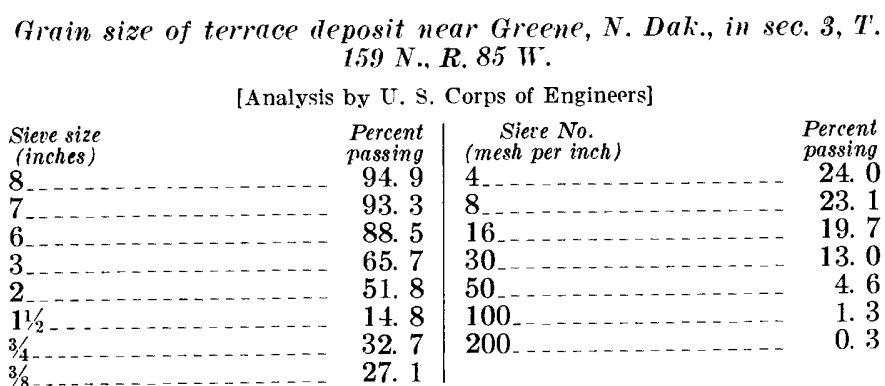

The deposit upon which the town of Greene is located, in secs. 24 and 19, T. 160 N., R. 85 W., appears to be nearly as coarse.

The largest boulders are concentrated chiefly in several terrace deposits between the lower reaches of the Des Lacs and Souris Rivers near Verendrye. In a 
few places, boulders completely stud the surface, where they have been concentrated by fluvial action that has removed the finer material and left the boulders; the number of surface boulders in such places far exceeds the number found a couple of feet beneath the terrace surface. A terrace remnant $4 \frac{1}{2}$ miles southeast of Carpio, in the SE $1 / 4$ sec. 22 , T. 157 N., R. 85 W., has about two-thirds of its surface almost completely covered with boulders that average 2 feet or more across (p1. $9 B$ ). The largest boulder exposed at the surface is limestone and measures 8 by 4 by 4 feet. A pink granite boulder 15 feet away is 5 by 4 by 3 feet. More than 90 percent of the boulders on the terrace surface are granitic rocks. Other terrace surfaces capped by large concentrations of boulders are found along the north bank of the Souris River northwest of Sawyer and abont 1 mile northwest of Verendrye. In contrast with terrace deposits that have large concentrations of boulders on the surface there is a deposit about 2 miles west of Minot, in sec. 21, T. 155 N., R. 83 W., that is relatively free of surface boulders but contains large local concentrations of boulders in the deposit itself. The upper half of this deposit, especially toward the south edge, contains boulders as much as 8 feet long. Gravel pits expose large boulders underlying a conspicuous terrace surface approximately 3 miles southeast of Minot, although the nearly flat surface is almost devoid of boulders.

Most deposits consist of fine to coarse gravel mixed with various amounts of sand. A few deposits contain beds of sand but these beds are a minor amount of the total deposit. The bouldery deposit 2 miles west of Minot, described above, also contains some of the thickest and most numerous sand beds exposed in any of the deposits. Silt is mixed with the sand and gravel in some terrace deposits but, except in the very poorly sorted deposits, it is usually present only in minor amounts. A very few beds consist entirely of silt or fine sand, but they are generally a foot or less thick.
Most material of cobble and boulder size is well rounded, but it includes many large tabular limestone boulders that have been broken along well-defined bedding planes. Material of pebble size is subrounded to subangular. The finer material is generally more angular than the coarser. Many of the larger rocks, such as coarse gravel, cobbles, and boulders, are striated. One or more sides of some are worn flat from abrasion, presumably from being dragged along the base of the ice. Many of the harder rocks, like quartzites, bear percussion marks.

The lithologic composition of the deposits appears to be the same as that of the diversion-channel deposits and of the till in fractions of corresponding size. A count of 57 pebbles taken from a gravel pit in the northwest part of Renville County in the NE1/4 sec. 3, T. 161 N., R. 86 W., shows the following percentages: limestone and dolomite, 51 percent; granite and granite gneiss, 26 percent; quartz, quartzite, and other quartzose rocks, 10 percent; basic fine-grained rocks and basalt 6 percent; miscellaneous (sandstone, siltstone, clay, lignite, and others) and other granitoid rocks, 4 percent. Boulders larger than about 3 feet are predominantly granite and granitic gneiss. Cobbles and boulders $1 / 3^{-3}$ feet in longest dimension are chiefly granitic rocks, followed in abundance by carbonate (limestone and dolomite) rocks; whereas pebbles $1 / 2-4$ inches long are predominantly carbonate rocks, followed by granitic rocks in abundance. Material of sand size appears to be chiefly quartz; feldspars and limestone are probably next most abundant. The above summary of lithologic composition in relation to grain size should not be interpreted rigorously, because statistical work is not sufficient for accurate confirmation. However, a complete analysis of material taken from the abovementioned gravel pit 4 miles southeast of Greene, in the SW1/4 sec. 3, T. 159 N., R. 85 W., is shown below:

Grain size, according to lithologic composition, of terrace-deposit material from gravel pit 4 miles southeast of Greene, $N$. Dak., in sec. $3, T .159$ N., R. 85 W.

\begin{tabular}{|c|c|c|c|c|c|c|c|c|c|c|c|c|c|}
\hline \multirow{2}{*}{ Rock type } & \multicolumn{4}{|c|}{ Sieve size (inches) } & \multicolumn{9}{|c|}{ Sieve No. (mesh per inch) } \\
\hline & 7 & 34 & $1 / 2$ & 3,8 & 4 & 8 & 16 & 30 & 50 & 100 & 200 & Gravel & Sand \\
\hline $\begin{array}{l}\text { Granite and granite gneiss } \\
\text { Basic igneous rocks. } \\
\text { Quartzite } \\
\text { Graywacke } \\
\text { Limestone } \\
\text { Chert } \\
\text { Mudstone } \\
\text { Cray-ironstone concretion } \\
\text { Quartz } \\
\text { Feldspar. } \\
\text { Mica } \\
\text { Miscellaneous }\end{array}$ & 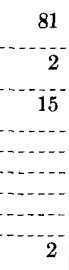 & $\begin{array}{r}39 \\
6 \\
5 \\
9 \\
36 \\
0 \\
1 \\
3 \\
1 \\
0 \\
0 \\
0\end{array}$ & $\begin{array}{r}39 \\
5 \\
9 \\
6 \\
38 \\
2 \\
1 \\
0 \\
0 \\
0 \\
0 \\
0\end{array}$ & $\begin{array}{r}39 \\
1 \\
1 \\
4 \\
47 \\
2 \\
2 \\
1 \\
1 \\
4 \\
0 \\
0 \\
0\end{array}$ & $\begin{array}{r}31 \\
3 \\
6 \\
3 \\
43 \\
3 \\
3 \\
0 \\
3 \\
4 \\
0 \\
1\end{array}$ & $\begin{array}{r}40 \\
2 \\
4 \\
3 \\
32 \\
2 \\
2 \\
2 \\
5 \\
8 \\
0 \\
0\end{array}$ & $\begin{array}{r}26 \\
1 \\
1 \\
2 \\
28 \\
1 \\
3 \\
3 \\
19 \\
15 \\
0 \\
1\end{array}$ & $\begin{array}{r}11 \\
0 \\
2 \\
0 \\
16 \\
0 \\
1 \\
2 \\
52 \\
15 \\
1 \\
0\end{array}$ & $\begin{array}{r}1 \\
0 \\
1 \\
2 \\
9 \\
2 \\
3 \\
3 \\
63 \\
15 \\
1 \\
0\end{array}$ & $\begin{array}{r}0 \\
0 \\
0 \\
1 \\
10 \\
2 \\
2 \\
3 \\
58 \\
13 \\
7 \\
4\end{array}$ & $\begin{array}{r}0 \\
0 \\
0 \\
0 \\
28 \\
2 \\
4 \\
5 \\
36 \\
6 \\
10 \\
9\end{array}$ & $\begin{array}{r}37 \\
4 \\
5 \\
5 \\
41 \\
2 \\
2 \\
1 \\
2 \\
1 \\
0 \\
\text { trace }\end{array}$ & $\begin{array}{r}11 \\
\text { trace } \\
1 \\
1 \\
17 \\
1 \\
2 \\
3 \\
47 \\
14 \\
2 \\
1\end{array}$ \\
\hline Total_- & 100 & 100 & 100 & 100 & 100 & 100 & 100 & 100 & $\overline{100}$ & 100 & 100 & 100 & 100 \\
\hline
\end{tabular}


Pieces of lignite occur throughout the deposits. They are chiefly small disseminated chips a fraction of an inch to an inch long. Even the smallest pieces are generally fresh, shiny, and resinous. Rarely, they are weathered to a sooty mass. The deposit 2 miles west of Minot contains conspicuously large chunks; many pieces are 1-4 feet long, and one chunk was obtained that reportedly weighed 2 tons and was burned for fuel. Nearly all chunks are roughly tabular and have fairly sharp edges that show little evidence of abrasion. In places, lignite chips form beds 1 inch to several inches thick.

Till balls are abundant in some of the more poorly sorted deposits. Most of the balls are 1-4 inches in diameter, but in the upper part of the terrace deposit 2 miles west of Minot some are as large as 8 inches in diameter. They are nearly spherical and are lithologically identical to the till of the ground moraine. They are probably chunks of till that were dropped into the glacial melt-water stream by the undercutting of till walls of the stream channel and became rounded during transportation. It does not seem possible that they could have survived transportation more than a short distance; hence, like lignite pieces, they are probably locally derived.

Detrital concretions are almost totally limited to poorly sorted deposits; even there they are rare. They range in size from a few inches to about 2 feet. Their lithologic composition is like that of concretions in the Fort Union formation, from which they probably are derived.

\section{BEDDING AND SORTING}

Bedding is indistinct to distinct. Beds generally range in thickness from a few inches to a few feet; most commonly they are 1-3 feet thick. Most beds are essentially horizontal; some show pronounced crossbedding in which the foreset beds dip $20-30^{\circ}$. Most exposures show no deformed bedding, but in the upper part of the Minot Sand and Gravel Co. pit 2 miles west of Minot, and to a lesser extent in a deposit 2 miles east of Minot, beds dip at angles greater than can probably be attributed to cross-bedding. These dips are probably caused by postdepositional slumping due to the melting of supporting ice.

Some deposits are well sorted, but most are poorly sorted. Poorly sorted deposits are especially prevalent in deposits along the Souris and Des Lacs River valleys upstream from the confluence of these rivers, where material ranging from boulder size to silt size are found in a single bed, and till balls $2-8$ inches in diameter are common. The material in the upper part of the Minot Sand and Gravel Co. pit is also very poorly sorted; it suggests torrential deposition and short transportation.
Some exceptionally well sorted beds of sand and silt, a few inches to a foot thick are interbedded with poorly sorted beds. A few beds consist almost entirely of fine pea-sized gravel (about 5-8 mm) or smaller, without any interstitial material. They are especially conspicuous in contact with beds containing poorly sorted material.

\section{INDURATION, CEMENTATION, AND WEATHERING}

Locally some beds are partly indurated by ferruginous cement, most abundantly in poorly sorted beds. Partial cementation near the surface is produced by caliche.

The deposits are weathered to about the same degree as the diversion-channel deposits; there is little decomposition, but there is marked disintegration of the larger biotite-rich rocks.

\section{SPECIAL IOCALTTIES}

The terrace deposit 2 miles west of Minot, in secs. 21 and 22 T. 155 N., R. $83 \mathrm{~W}$., is 1 mile long and as much as one-half mile wide. Its maximum altitude is slightly more than 1,680 feet-about 120 feet above the valley floor-but the greater part of its surface is between 1,600 and 1,640 feet. The northwestern part of the terrace is a flat surface bounded by the 1,680 -foot contour. A fairly distinct scarp, 40 feet high, separates this area from the much larger area to the east. and southeast. This larger area slopes moderately southeast toward the valley floor but is separated from that floor by a fairly abrupt scarp about 40 feet high. This scarp is studded with many boulders; the boulders are much less numerous on the sloping terrace surface and almost totally lacking on the higher surface bounded by the 1,680-foot contour. It appears that the 1,680 -foot level was the original terrace surface; the lower surfaces apparently are due, in great part, to removal of the finer material by glacial melt water, leaving a residuum of boulders.

The maximum known thickness of the deposit in the Minot Sand and Gravel Co. pit is 50 feet. This pit is in the southwest corner of the deposit, where the terrace surface is $40-50$ feet above the flood plain. The bottom of the pit reportedly rests on a blue clay, which is probably unoxidized till. Although the terrace surface is much higher in the northwest part of the deposit than at this point, the deposit itself is probably not correspondingly thicker. Bedrock is exposed at an altitude above the level of the bottom of the pit, along the edge of the terrace scarp to the northwest. Till probably also lies between the bedrock and the terrace deposits. Thus, the contact between the terrace 
deposits and the underlying material slopes fairly steeply toward the valley.

Two distinct intervals of deposition, are indicated by the deposits. The first interval is indicated by the material in approximately the lower half of the deposit in the Minot Sand and Gravel Co. pit, and the second interval by the upper half of the deposit in the same pit. The lower part of the deposit in the pit consists of well-sorted and well-bedded sand and fine gravel, such as is typical of a cut-fill terrace deposit. The presence, however, of large chunks of lignite indicates that it was transported only a short distance. The source of the lignite was probably just a short distance up the valley, inasmuch as lignite crops out on both sides of the valley in that vicinity. In marked contrast, the upper part of the deposit exposed in the pit is extremely poorly sorted and bedded, contains till balls as much as 8 inches in diameter, and consists of material ranging in size from boulders as much as 8 feet long to fine sand and silt. In places, the dip of the crudely formed beds appears to exceed that which could be attributed to crossbedding and may be due to collapse caused by removal of a supporting ice wall. All evidence points to a torrential ice-contact type of deposit. The contact between the upper and lower parts of the deposit is sharp and essentially horizontal.

\section{ORIGIN AND TYPE OF DEPOSITS}

The deposits were laid down by melt water during the last deglaciation of the area, but the exact manner of deposition is not clear. Several factors, none conclusive in itself, suggest that they may be a combination of cut terraces and kame terraces.

There is good evidence, which will be discussed later, that the valleys of the Souris and Des Lacs Rivers were cut prior to the last glaciation and were overridden by the last ice sheet. Ice and probably some debris carried by the ice-whether as lodgment till, englacial material, or ablation moraine-filled the valleys. The proportion of debris to ice in the valleys cannot be estimated; it probably differed from place to place. Upon deglaciation, the ice in the valleys probably remained longer than that on the adjacent upland. At that time, the melt water used the ice-filled river valleys as channels. In places, it probably flowed on the ice; in other places, between the ice and a valley wall; in yet other places, it may have been cutting entirely in till that had been deposited during the advance of the ice. During downcutting in both the ice and the till, sand and gravel were deposited by the melt water; during further downcutting, the deposits that were not removed by the stream were left as terraces. Terraces formed by streams flowing between an ice wall and a valley wall are kame terraces; those cut entirely in till are cut or strath terraces. Presumably all gradations exist between these two types.

Probably the most serious objection to interpreting the deposits as kame terraces is the apparent lack of collapsed bedding. Except in the deposit 2 miles west of Minot, few exposed beds are deformed. However, the outer edges of many of the deposits, where collapsed bedding would have been most prevalent, may have been largely removed since deposition. Meander scrolls almost completely cover the alluvium of the valley floors, and in most places it is evident that the bank of the river was against most of the terrace edges at one time or another. The large concentrations of boulders along these edges indicate that considerable fine material has been removed and only the coarser fractions remain. Thus, the existing deposits may have been sufficiently far back from the onter edge to have escaped collapse. J. H. Hartshorn states (oral communication) that in Massachusetts large kame terraces are horizontally bedded for some distance back from their valleyward margins. The tops of the terraces he describes are generally flat and have few or no kettle holes, which is also true of the terraces in the Souris River area.

There is fairly good evidence that the deposits are not remnants of fill terraces. The reasons are as follows:

1. The terrace remnants do not appear to be paired.

2 . If the terrace remmants are presumed to be remains of a fill that originally extended across the valley, the great volume of material already removed must be accounted for. There appears to be no place where this material could have been redeposited. Some of the terrace remnants are as much as 100 feet above the present flood plain-near the top of the valley walls: whereas, the lowest terrace levels are graded to the shoreline of glacial Lake Souris. If the valleys were flled nearly to the top with terrace deposits, an immense amount of material must have been removed. This material could have been deposited in only two places-in glacial Lake Souris and in the diversion channels. The deposits could have been carried into the lake either in its southeastern part or below Verendrye, where the lowest terraces are graded to the lake level. The combined areas in the lake and diversion channels do not appear to contain nearly enough deposits to account for the bulk that would be represented by the removal of terrace deposits as much as 100 feet thick from the valleys of the Souris and Des Lacs Rivers. Silt, sand, and local fine gravel are the only known deposits in glacial Lake Souris; most of them appear to have been deposited from glacial outwash channels that emptied into the lake. Furthermore, no material coarser than at the surface was penetrated by augering. The heads of the diversion channels contain sand and coarse gravel, but they do not contain cobbles and boulders, which are abundant in the terrace deposits. The material is progressively finer away from the heads of the diversion channels, so that only sand or finer material is present about 5 miles below the heads. The deposits in the diversion channels could account for only a very small proportion of the total terrace deposits that would 


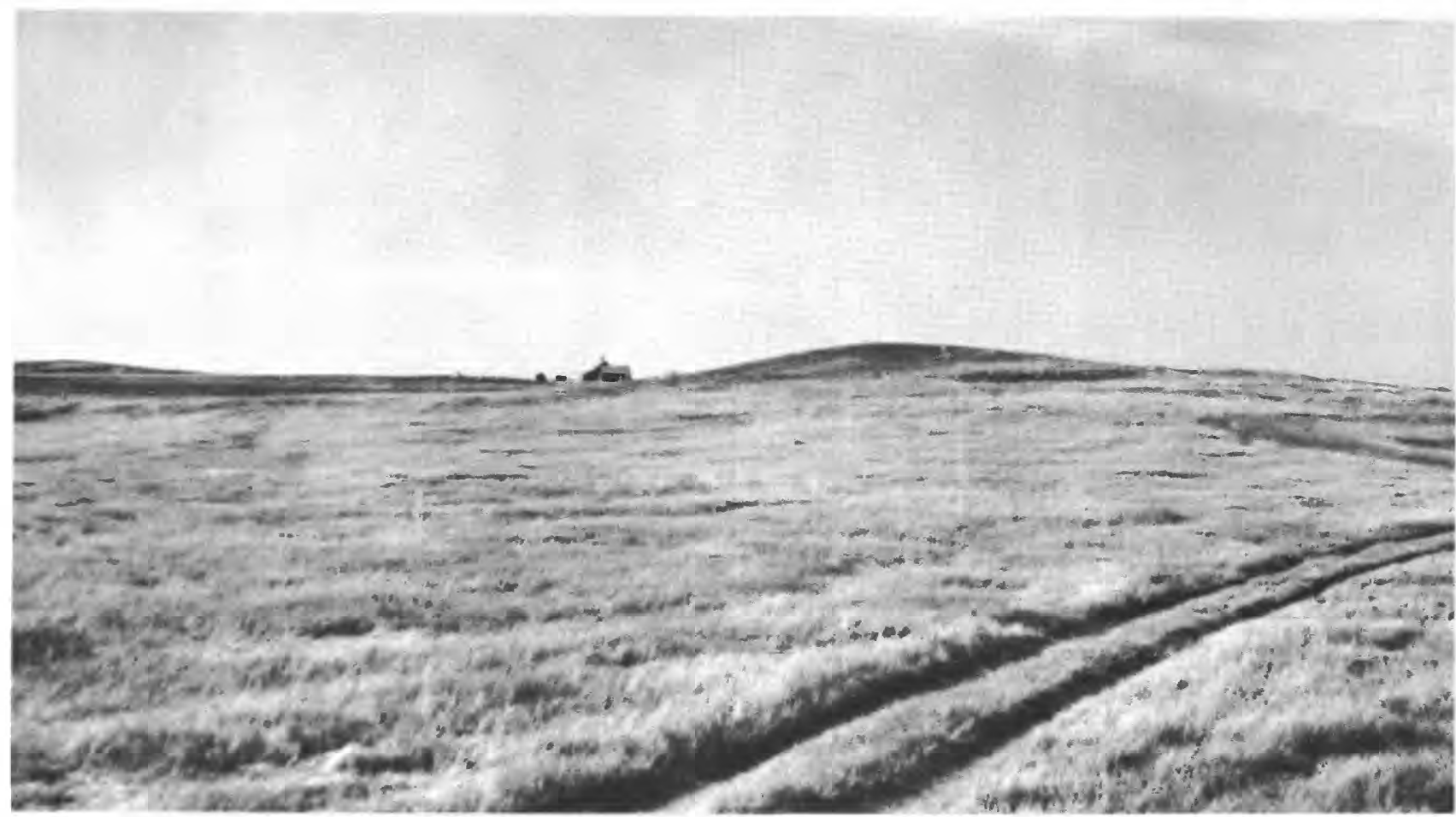

A. VIEW OF A TYPICAL KAME

Photograph by R. C. Townsend.

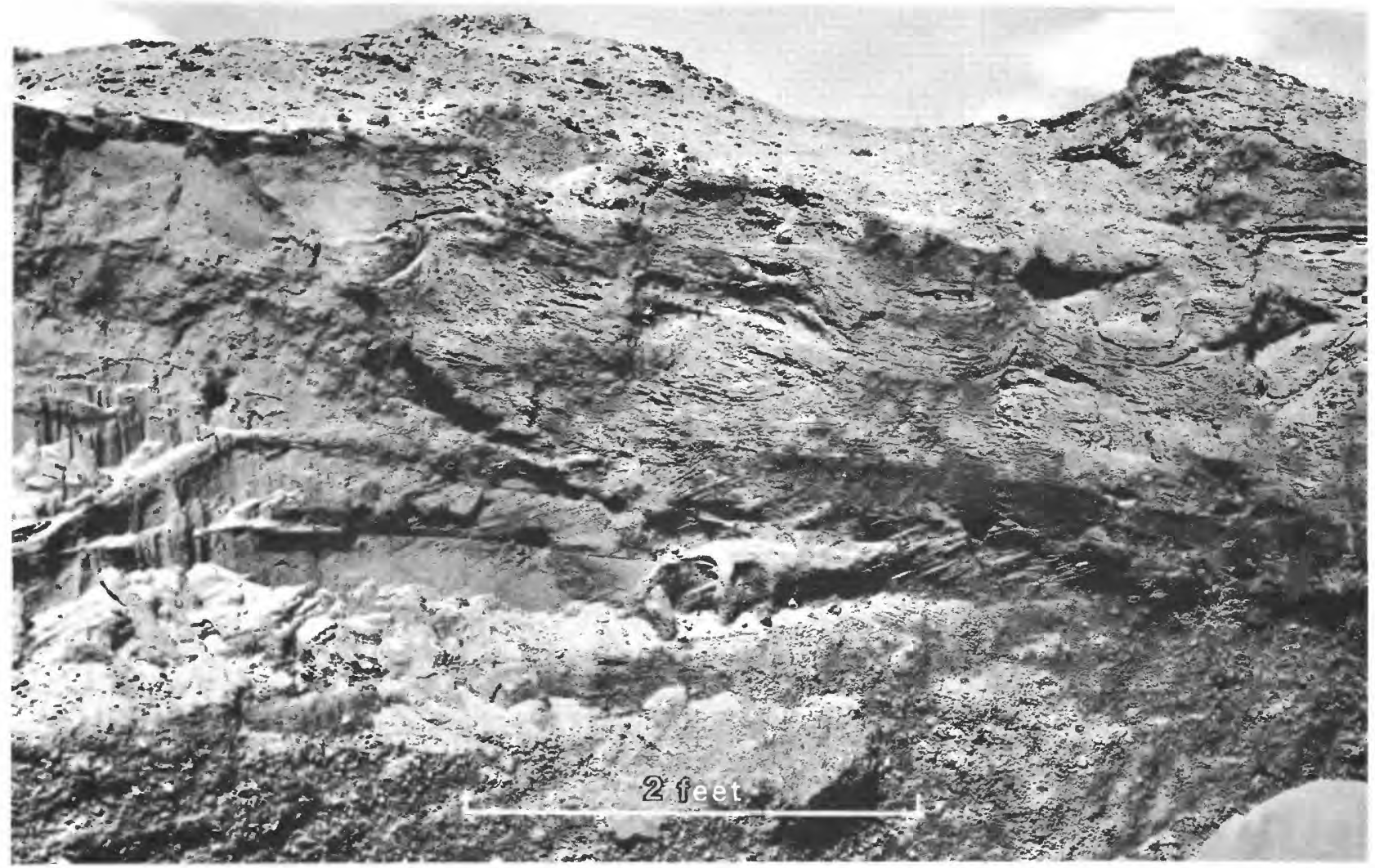

B. VIEW OF MATERIAL IN A KAME

Photograph by R. C. Townsend. 
have been removed, and they could not account for removal of terrace deposits at altitudes lower than the heads of the diversion channels. The supposition that the coarser fraction of the terrace deposit might underlie the valley alluvium, and the finer fraction was transported into the lake area and diversion channels, is not supported by augering through the valley fill.

3. The unusually large boulders in the deposits could not have been transported far by fiuvial action. Many are 3-6 feet long and some are as much as 8 feet long. Also some of the material, such as lignite chunks and till balls, indicate transportation for only a short distance. This material could probably not all be accounted for locally by erosion of the valley walls or adjacent ground moraine, because there is litle or no evidence of such erosion. Till of the Mankato substage veneers thinly the bedrock walls of the pre-Mankato valleys. The fact that this till has hardly anywhere been removed, exposing the adjacent bedrock, suggests that erosion was slight. The fact that undrained depressions in the ground moraine extend almost to the edges of the valleys also shows that there has been little erosion of the adjacent upland.

4. The deposits, in general, are poorly sorted, which indicates that they were not transported far before deposition. As pointed out in the previous paragraph, most of the deposits were probably not derived from the valley walls or adjacent upland.

5. If the valley had been nearly filled with material as coarse as existed in the terrace remnants, later downcutting would probably have occurred in the till walls and the adjacent ground-moraine plain rather than in the terrace deposits, because coarse gravel is exceptionally resistant to erosion. This fact is borne out by the behavior of small intermittent streams that fiow down the valley walls; where they come into contact with terrace deposits, they turn abruptly parallel to the valley wall and fiow across the clayey till along the back edge of the terrace instead of cutting across the less easily eroded terrace deposits.

\section{ENGINEERING GEOLOGY}

Permeability is high throughout most of the deposits. Drainage is also good, except where till or bedrock underlies the deposits at shallow depth; even in these places it is usually moderately good, because the contact between the terrace deposits and the underlying material slopes valleyward. Special consideration to prevent leakage should therefore be given to canals or dams constructed in these deposits.

Porosity is generally high, particularly in material that is well sorted and well rounded.

Foundation strength is also generally high; cuts less than 15 feet deep are moderately stable, and although some talus accumulates at the base of slopes as small fragments, unit masses of material slump very little.

Materials that might be deleterious in cement, either physically or chemically, are caliche, lignite, till balls, biotite-rich gneissic rocks that disintegrate easily, schistose rocks, platy sandstone or carbonate-cemented standstone, agate, and chert. Of these, the first four deserve the most serious consideration, inasmuch as the others are insignificant in most deposits. Caliche is easily dislodged from some pebbles; but it adheres tightly to others. As already described, lignite and also till balls are fairly abundant in some deposits. Disintegrated biotite-rich gneissic rocks are generally most abundant near the surface, though some occur at depth.

The tests tabulated on the following page, in addition to those already described, were made by the U.S. Corps of Engineers on material from a terrace deposit 4 miles southeast of Greene, in the SW1/4 sec. 3, T. 159 N., R. $85 \mathrm{~W}$.

\section{KAMES AND ESKERS}

The many kames and eskers scattered over the area range considerably in size, shape, lithologic composition and structure. However, they have three features in common: (a) They consist predominantly of poorly sorted gravel, sand, and silt, and contain minor amounts of till; (b) their bedding is deformed by collapse due to melting of supporting ice; and (c) they occur typically as mounds or sinuous ridges that differ from glaciofluvial deposits. All gradations in shape and structure exist between kames and eskers, so that in many places one cannot be differentiated from the other; they are therefore shown on the geologic map as one unit but are discussed separately.

RAMES

NAME, LOCATION, AND AREAL EXTENT

The kames are irregular hills and low mounds that consist predominantly of ice-contact stratified drifts and show evidence of collapsed bedding. Although kames are abundant, their areal extent is small. Most deposits are on the ground-moraine plain. Nearly all the remainder are on the Max moraine, although one of the largest kames is surrounded by deposits of glacial Lake Souris. Kames on the ground-moraine plain are detected by their height above the surrounding flat surface, where even the lowest mounds are conspicuous. However, because of the jumble of hills and depressions on the surface of the Max moraine, it is difficult to determine which hills are kames and which ones consist of unstratified drift.

SHAPE AND SIZE

The kames range in height from slightly perceptible rises less than 5 feet high to well-defined hills, one of which is 125 feet high; but most are 10-20 feet high and have gentle to moderately sloping sides (see pl. $10 A$ ). Most kames are irregular in shape and have a tendency to be elongate or arcuate; a few small kames are nearly round or oval. There is a complete gradation in form between the longer kames and eskers. 
Physical characteristics, by size fractions, of terrace deposit 4 miles southeast of Greene, N. Dak., in the $S W 1 / 4$ sec. 3, T. 159 N., R. 85 W.

[By U. S. Corps of Engineers]

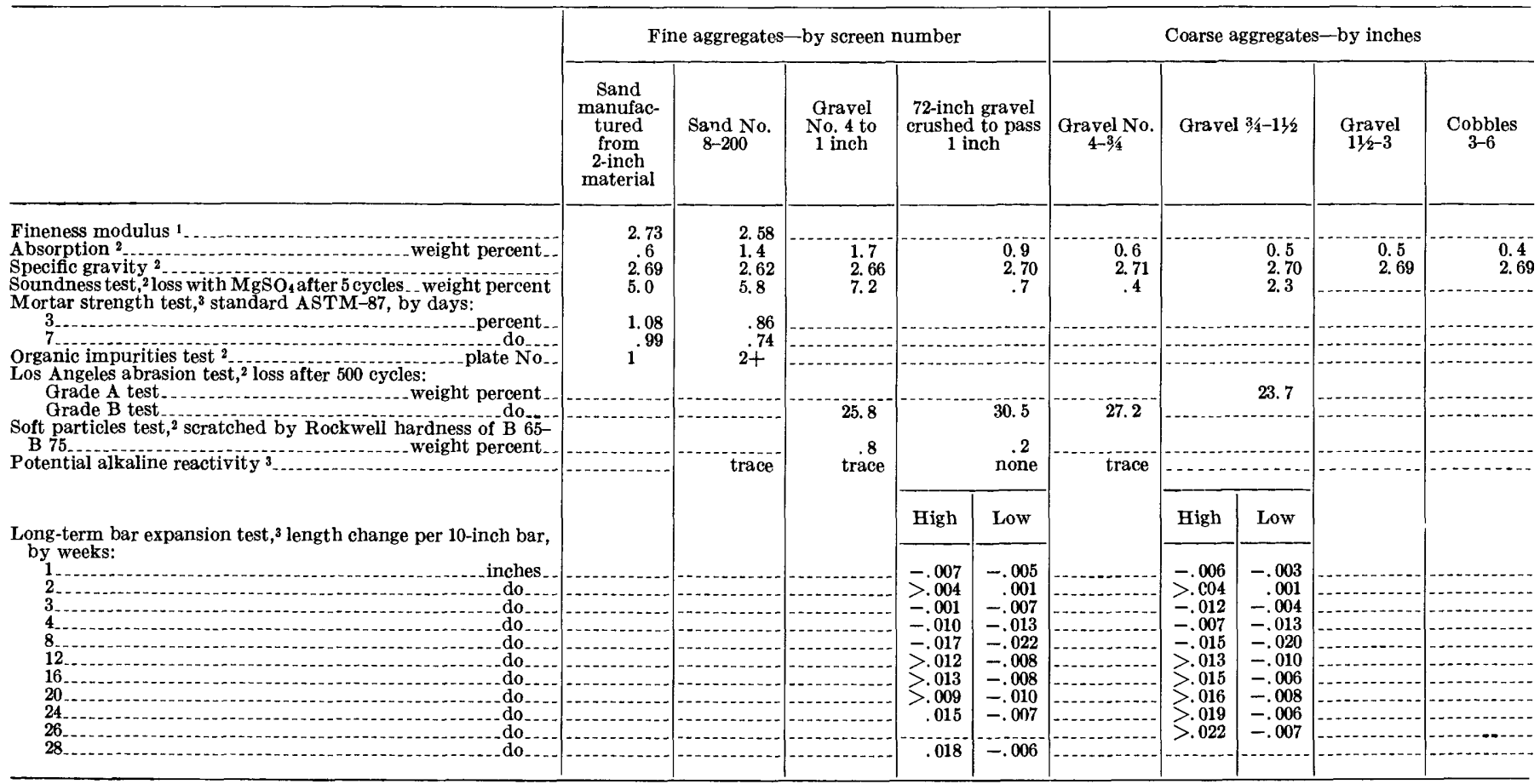

1 Test described in State Highway Commission of Kansas, 1945, Standard Materials Specifications for State Road Construction and Maintenance, p. 168.

2 Tests deseribed in American Society for Testing Materials, 1949, Book of A. S. T. M. Standards, including tentatives, part 3.

3 Tests described in U. S. Corps of Engineers, Waterways Experiment Station, 1949 Handbook for concrete and cement, Vicksburg, Miss., pt. 2.

STRATIGRAPHIC POSITION AND AGE

Younger geologic units overlie the deposits only in the glacial Lake Souris area, where a few kames are flanked and partly overlain by glacial-lake deposits. Most kames are underlain by till. They were deposited during the last deglaciation of the area.

GRAIN SIZE, SHAPE, AND LITHOLOGIC COMPOSITION

Most kames consist predominantly of sand and gravel (see pl. 10B), although a fairly large number of mounds in Burke County in the vicinity of Flaxton consist chiefly of silt and sand. However, material of cobble and boulder size is common in some deposits, and many kames are capped by scattered boulders 1-4 feet long. Till mantles the flanks of many mounds and to a lesser extent intertongues with the stratified material.

Pebble counts made by Townsend $(1951 ; 1954 \mathrm{a}, \mathrm{b}, \mathrm{c})$ of samples taken from kames in the Columbus, Noonan, Crosby, and Portal quadrangles west of the mapped area show that limestone and dolomite are the dominant material and granitic rocks are consistently common. Shale is common in some deposits.

Till balls 2-8 inches in diameter are common in some deposits. Locally beds a fraction of an inch to 4 inches thick are composed of lignite fragments and woody material. As denoted by pebble counts, shale is a more common minor constituent of kames than of any other surficial deposits, except possibly eskers. Schist is relatively abundant, as is the miscellaneous group which includes sandstone, siltstone, clay, till balls, lignite, limonite, and other materials. This may be due to the fact that these types of material are easily broken into minute particles in transport over any great distance, as in outwash channels, but are preserved in the kames because of short distance of transport.

\section{BEDDING AND SORTING}

The material is predominantly poorly bedded and sorted, but it is not unusual for well-stratified silt, sand, or fine gravel beds to be in sharp contact with poorly sorted material, or in contact with lenses of till. Crossbedding is pronounced in some beds. A large number of mounds in the Flaxton area consist chiefly of thinly laminated sand and silt. These mounds are discussed in greater detail under the heading "Special localities."

Many beds are deformed (see pl. 10B), owing to collapse after melting of supporting ice walls. Shear planes are common, and many beds are tilted at angles ranging from a few degrees to vertical. A few have been folded but are not severely distorted. 
INDURATION, CEMENTATION, AND WEATHERING

Poorly sorted beds are partly cemented in a caliche zone 2-5 feet thick, in the lower part of the soil horizon. These beds are also commonly highly stained by ferruginous material. In places, the ferruginous material cements the beds into a conglomerate, more indurated than beds cemented with caliche.

The only rocks noticeably weathered are biotite-rich granitic rocks; they are disintegrated to about the same extent as similar rocks in other stratified deposits.

ORIGIN AND TYPE OF DEPOSIT

Kames, in general, originate in diverse ways (Holmes, 1947, p. 240-249), and the kames in this area are probably no exceptions. The origin of several unusual types of kames is discussed under the heating "Special localities."

Kames commonly inclucle sheared and tilted beds. Folds are less common but are prevalent in some places. All of the deformed structures are due to collapse and slumping as the result of the melting of one or more supporting ice walls; if ice had underlain the deposits, much more deformation would have resulted from lowering the deposits to the ground as the ice melted. Thus, it appears that most kames were deposited at the ice margin by glacial streams that dumped their loads because of markedly decreased channel gradients; however, some more conical features may be moulin kames. If a melt-water stream notched the ice edge sufficiently to erode a channel to the ground surface, the kames may have been deposited in successive increments farther up the ice-walled channel. Such deposits would have two supporting walls. If deposition continued headward as the chammel deepened, an eskerlike ridge might result. Such a deposit would probably not be distinguishable from eskers of similar shape. In this type of feature, englacial and superglacial till, melting out of the ice walls, could rather easily move downslope and become incorporated with the stratified deposits, especially along the flanks of the deposits. This would account for the till lenses that are incorporated in many of the deposits. Movement of this kind, both as fastmoving mudflows and as slower debris flows, has been witnessed by the author, both in valley glaciers of the Columbia Icefield in Canada and in outlet glaciers in northern Greenland. On almost any warm day, numerous small mudflows could be seen sliding down moderate to steep ice slopes. On gentle slopes, movement was generally slower and larger masses were involved in the movement.
SPECIAL LOCALITIES

A somewhat anomalous feature that is believed to be a moulin kame rises to a height of 115 feet above the surrounding plain in Ward County, 11/2 miles northeast of Sawyer. A second unusual kame, 125 feet high, lies on the relatively flat floor of glacial Lake Souris in McHenry County, 5 miles northeast of Granville; it is not only the most conspicuous hill in the area but also the largest kame in the mapped area. A third unusual type of feature is a series of low mounds in the vicinity of Flaxton, in Burke County. These are not of conspicuous size but are unusual in that their cores consist predominantly of thinly laminated silts and sands.

The high hill 11/2 miles northeast of the town of Sawyer, in the $\mathrm{S} 1 / 2$ sec. $1, \mathrm{~T} .153 \mathrm{~N} ., \mathrm{R} .81 \mathrm{~W}$., is known as Black Butte. Except for some small sinuous ridges that lead southward away from its base, it is roughly conical in outline and has fairly abrupt sides. A small undrained depression on the crest proves that it has not been lowered to any great extent by erosion. Granitic boulders, as much as 5 feet long, are concentrated locally on the slopes and top.

Except for scattered small lenses of till, the entire feature appears to consist of sand, gravel, and smaller amounts of cobbles and boulders. Four gravel pits have been dug near the base of the hill on the eastern and northern sides. In general, they expose poorly sorted coarse sand and fine gravel. However, cobbles 6-10 inches in diameter are locally common, and a few boulders as much as 3 feet long are exposed. Irregular blocks of till, $2-5$ feet long, are exposed in a pit on the north side of the hill. Other pits contain a few till balls and attenuated lenses of till, a few inches long. One pit exposes a 2 - to 4 -inch layer consisting almost entirely of small lignite fragments.

In all exposures in this feature, bedding is considerably deformed. Nearly all beds are tilted at angles as great as $35^{\circ}$, and the dips generally conform with the natural surface slope. Faults and minor folds are conspicuous in one of the pits on the north side of the hill.

A hypothesis to explain the origin of the kame is that melt water from the surface of the wasting ice sheet deposited sand and gravel in a hole in the ice and perhaps also along some outlets at the bottom of the hole. The outlets are now represented by sinuous ridges at the base of the hill. Deposition continued until the hole was filled or until the melt water was diverted. Later, as the surrounding ice melted away, the deposit collapsed, the bedding along the edges collapsing downward to conform fairly closely with the present natural profile. Additional faulting and folding occurred at this time. Large concentrations of boulders, as much as 5 feet long, indicate that the volume of melt water 
carrying the deposits was large. The deposit is also noteworthy in that it is one of the largest single kames of this type known to exist in the northern Great Plains area.

Buffalo Lodge Butte, a kame 5 miles northeast of Granville, in secs. 13 and 25, T. 156 N., R. 79 W., rises prominently along the west shore of Buffalo Lodge Lake to a total height of about 125 feet above the otherwise subdned sandy floor of glacial Lake Souris. In some respects it resembles the conspicuous kame northeast of Sawyer, but in other ways it is different. Both kames are isolated hills and there are nearby no similar features of comparable size. Both appear to consist essentially of poorly sorted sand and fine gravel. The kame near Sawyer is roughly conical in outline. Buffalo Lodge Butte, although rising abruptly, is crested by a series of narrow sinuous sharp-sided ridges about 50 feet high. Till is exposed along the bottom 25 feet of the eastern side of the feature, where it breaks off sharply into the lake, which indicates that the entire base and possibly the core of the hill also consist of till. Undrained depressions on top of the feature indicate that very little material has been removed by erosion since deposition. Unlike the kame near Sawyer, Buffalo Lodge Butte is free of boulders.

A gravel pit on the crest of Buffalo Lodge Butte exposes poorly sorted and nearly unstratified sand, and fine to medium gravel. The crude bedding is deformed. Beds near the top of the pit are tilted nearly parallel to the slope of the hill. The underlying beds, however, are tilted at angles up to vertical and, in places, are probably overturned. A series of small faults, trending at right angles to each other, have offset the beds into separate blocks about 1 foot across. From the base of the hill above the till to about onethird of the way up the slope, the surface material is nearly all sand similar to that of the surrounding lake sediments. Inasmuch as the feature was an island when glacial Lake Souris was in existence, lake sediments were probably deposited around the lower flanks of the hill. However, inasmuch as the surface of the lake at its highest level in this area was at an altitude of approximately 1,515 feet, the water was only about 35 feet deep around the base of the hill. The sand that occurs as high as an altitude of about 1,520 feet where it probably was blown upslope by the wind, was pushed upslope by lake ice, or reflects a crustal rebound of 5 feet.

Low mounds in the vicinity of Flaxton have been included with the kame deposits, although their origin is probably different from that of typical kames. They generally rise 5-20 feet above the surrounding till plain but in places are almost imperceptible upon the gently undulating surface. The cores of the deposits consist essentially of thinly laminated well-sorted sand and silt beds. Gravel is rare. Till commonly overlies the sand and silt along the flanks of the deposits and forms a cover 1-4 feet thick over the tops of some deposits. The till is unusual in that it shows faint lines of stratification or flow lines, as though it had been partly reworked by melt water at the time of deposition or had been involved in sliding. The sand and silt beds are considerably deformed; many are tilted at angles nearly as great as $90^{\circ}$ and are sheared. Individual beds are commonly offset several feet. The beds that are least disturbed appear to dip roughly parallel to the side slopes of the deposits.

Because the stratified parts of the deposits consist of thinly laminated silt and sand, they probably were deposited by streams moving across small ponded depressions floored with thin ice, or grounded depressions surrounded by ice. Strong deformation indicates that the beds collapsed when supporting ice melted. The fact that till commonly flanks the stratified parts of the deposits and locally forms the crests of the features suggests ponds in fairly deep, steep-walled holes in the ice. Ablation till and englacial till melting out from the ice walls that supported the deposits may have slid down as mudflows onto the edges of and in some places entirely across, the deposit. The occurrence of mudflows on the deposits could probably account for the faint stratification present in the till along the flanks of the deposits. If the ponds had an ice floor, the ice must have been only a few feet thick or the bedding would have been entirely destroyed when the underlying ice melted.

\section{ENGINEERING GEOLOGY}

Permeability is generally high, but poorly sorted beds, caliche-cemented zones, and tongues and irregular masses of clayey till locally prevent good drainage. Drainage is generally good on the surface and in the upper part of the deposits, as shown by the lack of water in many gravel pits dug in kames. However, some pits are operated by dragline below the water table. These deposits appear to be poorly drained, either because they are surrounded by nearly impervious till or because they are near ontwash channels in which the water table is near the surface. Some kames are capped by a nearly impervious layer of clayey till $1-5$ feet thick.

Except for a few boulders, these deposits can generally be worked with hand tools and can be worked easily with light power equipment. Draglines and light power shovels are often used for excavation. Compaction may be difficult or easy depending on the 
degree of sorting of the beds and the grain size of sediments; silt and silty sand beds may require special handling.

Natural sod-covered slopes are fairly stable. Cut slopes in sand and silt have low stability; these materials wash downslope easily. Moderately steep slopes can be maintained in poorly sorted gravels. Till-rich slopes are generally stable unless the slopes are undercut. Foundation strength varies greatly in different places. The deposits are widely used as sources of sand and gravel, but locally they contain excessive amounts of lignite chips and till balls. The topographic prominence of many kames provides good surface drainage for home sites and other structures, with the result that many rural dwellings are built on them.

\section{ESKERS}

NAME, LOCATION, AND AREAL EXTENT

Eskers are sinuous ridges of ice-contact stratified drift. They are most abundant on the ground-moraine plain, east and southeast of Velva, and in scattered localities on the Max moraine.

Most individual ridges are a couple of hundred feet wide at the base and several miles long. Composite eskers consisting of several sinuous ridges, partly coalesced, are present on the Max moraine. They are commonly 2-4 miles long and are as much as one-third mile wide.

\section{SHAPE AND SIZE}

Eskers generally stand 10-25 feet above the surrounding terrain. Commonly, they consist of coalesced mounds forming sinuous uneven-crested ridges. These coalesced mounds generally thin out nearly imperceptibly along their trend into isolated kames.

\section{STRATIGRAPHIC POSITION AND AGE}

The eskers are nowhere overlain by younger deposits. So far as is known, they are underlain by till and were deposited by melt waters during the last deglaciation of the area. The sinuous esker southeast of Verendrye is younger than the long linear ridge to the northeast, inasmuch as the stream that built the esker cut across the linear ridge.

GRAIN SIZE, SHAPE, AND LITHOLOGIC COMPOSITION

Most of the eskers consist of mixed sand, gravel, and intercalated till. Cobbles and boulders are abundant locally. Silt forms sparse but distinct beds. Pebble gravel, cobble, and boulder-size material is generally subangular to subrounded and of the same lithologic composition as material of similar size in kames.
BEDDING AND SORTING

The degree of bedding and sorting ranges widely. Till lenses are common in some deposits; locally, till balls are mixed sparingly with the stratified deposits. Although till lenses are probably not quite as prevalent as in some isolated kames, till commonly forms the flanks of the ridges and, in places, mantles the tops thinly. Boulders are concentrated along the crests of some ridges. In places, bedding is sheared, tilted, and otherwise deformed, owing to slumping after the supporting ice walls had melted. In general, though, deformation is less severe than in kames.

The long, sinuous esker in McHenry County between Verendrye and Bergen consists chiefly of moderately well to poorly sorted silt, sand, and fine gravel, as shown by several pits opened for road material. A few boulders are scattered along the flanks and top of the feature. The composite esker on the Max moraine in Mountrail County, about 4 miles southeast of Tagus, consists mostly of very poorly sorted coarse gravel and plentiful cobbles, boulders, and till. Boulders are so concentrated on the crests and flanks of some ridges that they form nearly continuous boulder pavements. The till size fraction of the deposits forms the flanks of the ridges and intertongues with the stratified parts of the deposits as large, irregular lenses.

Figure 11 is a generalized cross section of the crest of a particularly till-rich esker that is exposed in a cut in Mountrail County, in the SE1/4 sec. 33, T. 156 N., R. $87 \mathrm{~W}$.

A composite esker on the Max moraine in the southeast corner of Ward County consists mostly of poorly sorted gravel but cobbles and boulders are fairly plentiful. The low, sinuous braided esker system in Ward County, about 2 miles north of Foxholm, is of interest because, in many places, it consists predominantly of till; stratified material is confined to a small basal core or is absent. The stratified parts consist mostly of poorly to moderately well sorted sand and fine gravel.

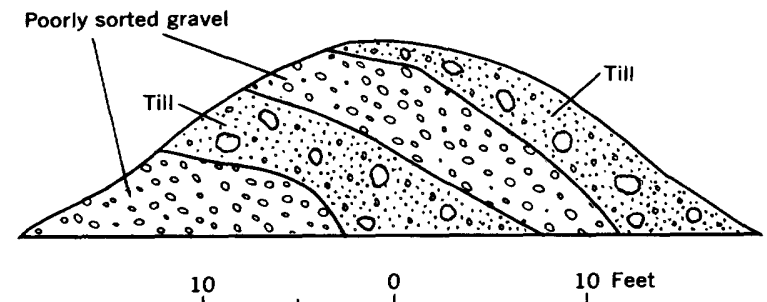

Figure 11.-Generalized cross section of the crest of a till-rich esker in Mountrall County, in the SE1/4 sec. 33 , T. $156 \mathrm{~N} ., \mathrm{R}$. $87 \mathrm{~W}$. 
INDURATION, CEMENTATION, AND WEATHERING

There is little induration or cementation other than partial cementing by caliche. Caliche is especially prevalent in poorly sorted parts of the deposits. Eskers have the same weathering characteristics as kames.

ORIGIN AND TYPE OF DEPOSIT

The eskers were deposited by melt waters during deglaciation of the last ice sheet that covered the area, but the exact mode of origin is unclear. Most are believed to have been deposited in a tunnel at or near the base of the ice. Some, however, may have been deposited at the mouths of subglacial streams by successive increments of material as the ice edge receded. Still others may have been deposited in tunnels wholly within the ice or in ice-walled channels opened to the sky.

Sharp, in his excellent paper (1953, p. $855-883)$ on eskers in Cook County, Minn., not only discusses the origin of eskers in that area but also cites extensive literature pertinent to eskers in the Souris River area. The fact that many of the eskers in the Souris River area are flanked with till and that till commonly forms their tops indicates that deposition was in an englacial tunnel or in a superglacial channel. If deposition was in a subglacial tunnel, the till forming the surface deposits of the ridges can be attributed to the collapse of englacial till onto the stratified deposits during melting of the overlying ice. The idea of a tunnel at the base of the ice is favored over that of a tunnel wholly within the ice, because it is difficult to believe that a deposit could be let down to the ground more than a very short distance in the ice without modifying extensively or destroying the stratification of the deposit (see Flint, 1947, p. 154). If deposition was in a superglacial channel, the channel walls must have been sufficiently high and steep to allow ablation moraine to slide across the stratified deposits, in order to account for the till on the flanks and crests of the eskers. The writer is of the opinion that deposition in a tunnel at or near the base of the ice is the more likely possibility for most of the eskers.

The segmented eskers might have been formed by esker streams that flowed in part at the base of the ice and, in part, wholly within the ice. The gaps in such eskers would represent segments of a stream that were wholly within the ice, where the deposits were subsequently destroyed during the melting of the enclosing ice. On the other hand, the gaps might merely be those parts of the stream course where no deposits were laid down. Short ridges not covered by till might have been deposited in superglacial channels near the ice edge, where the channels were too shallow to allow ablation moraine to slide over the stratified deposits.

\section{SPECIAL LOCALITIES}

Two areas of coalesced eskers are on the Max moraine. One area is in the southeast corner of Ward County, and the other is in Mountrail County, about 4 miles southeast of Tagus.

The northwest end of the coalesced eskers in the southeast corner of Ward County arises as a series of subparallel ridges that unite into a recticulated network of ridges in a distance of less than one-half mile. This network extends to the southeast for a distance of more than 1 mile. Directly south of this esker assemblage, and probably closely related to it, are nearly parallel sinuous ridges with indistinct, canallike intervening troughs. The troughs can be seen well on aerial photographs. Because of the map scale, the parallel ridges and intervening trough are mapped as a single ridge. The ridge crests are generally less than 20 feet above the troughs, and the bottoms of the troughs are usually less than 200 feet wide. How two parallel eskers can form in this manner is unclear. R. B. Colton (oral communication) has pointed out well-formed parallel esker ridges and intervening canallike troughs on aerial photographs of an area about 13 miles north of the town of Harlem, in north-central Montana. He speculated that both ridges were deposited in a single superglacial channel on ice only a few feet thick. Ice on both sides of the channel melted before the protected ice melted underneath the deposit in the floor of the channel. Part of the deposit then slid to the ground on one side of the former channel and the remainder slid down the other side, thus forming individual ridges. The ice that had been under the channel then melted away, leaving the intervening trough.

The northern end of the composite esker in Mountrail County near Tagus arises as a series of coalesced subparallel ridges. In less than half a mile, the ridges separate to form a braided pattern. Fairly deep canallike troughs occupy the areas intervening between the ridges. The crestlines of the ridges slope to the south, which suggests that the esker stream flowed south.

The composite esker in Ward County north of Foxholm forms a braided pattern of sinuous ridges so low that they are barely perceptible on the ground-moraine plain. However, they are clearly discernible on aerial photographs. In most places, they are $2-8$ feet high, but they reach a maximum height of about 15 feet. They are evenly crested along only short segments of their length. Associated with the eskers are very low kames. All gradations in shape exist between the kames and eskers. 
The longest and most conspicuous esker is in McHenry County between Verendrye and Bergen. It trends unbroken as a narrow, sinuous ridge for about 5 miles. Additional segments extend for an additional 2-3 miles to the northeast. The ridge is 5-20 feet high, steep sided, and unevenly crested. The esker was breached in two places by the same stream that earlier had built the downstream part of the esker.

ENGINEERING GEOLOGY

The physical characteristics of the eskers are similar to those of kames. Slopes on some eskers are steeper than on low, mound-shaped kames. In these places, surface drainage is better. The eskers also have greater lateral continuity; hence, individual deposits afford a greater source of sand and gravel than can usually be found in a single kame.

\section{END MORAINES IN SOURIS LOOP AREA}

NAME, LOCATION, AND AREAL EXTENT

Five hummocky morainal areas in the Souris loop area are mapped as end moraines. These moraines contain a greater proportion of stratified drift than most other end moraines in the region.

The largest end moraine lies north of the Souris River between Granville and Verendrye in southcentral McHeury County. It is about 6 miles long and as much as $41 / 2$ miles wide. On the Velva topographic sheet, part of this area is called the Henderson Hills. Four small tracts lie immediately to the north. These small areas were probably all part of the same mass at one time but were separated by glacial-lake deposits that were laid down in the low intervening areas. The other 4 morainal areas are all less than 4 miles long and are generally less than 1 mile wide.

\section{SHAPE AND SIZE}

The largest and most conspicuous end moraine rises abruptly 100 feet above the glacial-lake deposits that lie to the north and northeast and the ground-moraine plains that lie to the northwest. Toward the south, its crest is progressively lower until, near its southwestern edge, it merges imperceptibly into the groundmoraine plain. The surface, especially the northern half, is marked by many deep, undrained depressions and kamelike knobs or irregular ridges. The ridges trend, in general, in a northerly to northwesterly direction. Some depressions are as much as 20 feet deep. A sag several miles long in the northern part of the moraine resembles an outwash channel, but its floor is very uneven and contains no outwash; hence, the feature probably is constructional rather than erosional.
A second conspicuous moraine, in south-central McHenry County, is confined almost entirely to sec. 32, T. 154 N., R. 79 W. A scarp about 100 feet high marks its northern and western edges but becomes indistinct to the east. The southern edge is truncated by a river terrace. The central part is hummocky but less so than the area described above. Drainage is integrated along its southern flank.

A third moraine in the westem part of McHenry County is about 1 mile north of Velva. It is less prominent than the two areas previously described and grades imperceptibly into the ground-moraine plain.

Two morainal areas in Ward County east of Burlington are less conspicuous topographic features than those in McHenry County. Of the two, the feature nearest Minot is the more prominent. Nowhere, however, does it rise more than 50 feet about the surrounding groundmoraine plain; in most places, it merges imperceptibly into that plain. It is an uneven ridge that consists essentially of kamelike knobs and small undrained depressions. On the basis of shape and lithologic composition, there is a question whether it should be mapped as an end moraine or as a kame field. The other morainal area, about 1 mile farther west, is very inconspicuous and was distinguished from ground moraine chiefly on a lithologic basis.

\section{STRATIGRAPHIC POSITION AND AGE}

Bedrock underlies at least one moraine at a higher altitude than it underlies the surrounding terrain. A well on the northwest scarp of the largest end moraine, in sec. 3, T. 154 N., R. 79 W., was dug into bedrock within 10 feet of the surface. The bedrock is here at least 30 feet higher than the surrounding ground-moraine plain; it may be considerably higher under the crest of the deposit. Bedrock probably also forms the core of the other two deposits in McHenry County, but it is $\mathbf{1 0 0}$ or more feet below the surface in the two moraines in Ward County.

The only younger deposits that overlie the end moraines are glacial-lake deposits that overlap low areas along the north edge of the largest deposit in McHenry County. The end moraines were deposited during the last substage of glaciation to cover the area, and most of the deposition, especially the stratified material, probably took place during the recession of the ice front.

\section{GRAIN SIZE, SHAPE, AND LITHOLOGIC COMPOSITION}

The moraines contain all gradations of material from boulders as much as 5 feet long to particles of clay size. The till parts of the moraines consist mostly of clay, silt, and sand. The stratified parts of the moraines consist predominantly of sand and fine gravel; silt and clay are next in abundance. 
The northem half of the largest moraine in McHenry County consists predominantly of gravel, sand, and minor amounts of silt. The relatively small amount of till that is present forms the low intervening areas between the knobs, or it forms iregular-shaped masses incorporated in the stratified material. From north to south in the deposit, till is progressively more abundant, so that the southern half of the deposit consists predominantly of till; but even this half of the feature contains proportionately more gravel, sand, and silt than the ground moraine or the Max moraine. Boulders are especially abundant at the surface on the northern half of the deposit.

The end moraine in sec. 32, T. 154 N., R. 79 W., in McHenry County, appears to consist chiefly of gravel, sand, and silt. Till forms irregular lenses or blobs. Many of the higher crests are heavily studded with boulders.

The remaining morainal areas appear to contain more stratified than nonstratified material. The stratified material, which consists of gravel, sand, and minor amounts of silt, is confined chiefly to the kamelike knobs of the deposits. Till commonly composes the intervening lows, though there is some stratified material.

The shape of most of the coarser material is subangular to subrounded. In general, the material is somewhat less rounded than the same size fraction in diversion-channel deposits, river-terrace deposits, and ice-marginal outwash-channel deposits. The finer fraction is more angular than the coarse material.

Nearly all stratified parts of the moraines contain till balls and chips of lignite. Till balls are generally less than 4 inches in diameter and are most prevalent in the poorly sorted parts. Lignite commonly occurs as small chips less than one-half inch long and is most common in the better sorted parts of the deposits. In places, lignite chips are sufficiently concentrated to form thin stringers or beds a fraction of an inch to a couple of inches thick.

\section{BEDDING AND SORTING}

The stratified material is generally poorly sorted and poorly bedded, though in a few places it is well sorted and well bedded. Individual beds are generally less than $t$ feet thick but more commonly 1-2 feet thick.

The bedding in many of the deposits is considerably deformed, owing to collapse as a result of the melting of supporting ice walls. Many beds are tilted at steep angles; some are vertical. Shear planes are common, and some beds are folded.

\section{INDURATION, CEMENTATION, AND WEATHERING}

Stratified parts of the deposits are indurated and cemented to about the same extent as in kames. Parts of the deposits that consist of till are similar, if not identical, to the adjacent ground moraine. Weathering, also, is similar to that of kames in the stratified parts of the deposits and similar or identical to that of adjacent ground moraine in the unstratified parts of the deposits.

\section{ORIGIN AND TYPE OF DEPOSIT}

The end moraines were deposited during recession of the last ice that covered the area. They appear to mark locally a pause of the front sufficiently long to enable fairly thick stratified and unstratified deposits to accumulate. Deposition appears to have been restricted to small areas where bedrock or till acted as a partial barrier to ice movement.

\section{ENGINEERING GEOLOGY}

Permeability is high in the stratified parts of the deposits, but very low in the till parts. Likewise, porosity is fairly high in the stratified deposits but generally low in the till.

Foundation strength is probably moderately high for most of the moraine deposits, both stratified and unstratified. Highway and other cuts excavated in this material range considerably in slope stability. Because of the diversity and irregular distribution of the deposits, it is net possible without subsurface data to predict what materials will be encountered in an excavation. Till, in cuts of less than 20 feet, maintains near-vertical slopes. When it does fail, it breaks off in chunks along nearly vertical fracture planes. Likewise cuts less than 20 feet high in coarse gravel are moderately stable, even at steep slopes. Fine gravel and sand are less stable and tend to erode easily. Roads built on the till parts of the deposits rut badly when wet but afford a firm hard surface when dry.

Caliche, lignite chips, till balls, till lenses, biotiterich gneissic rocks, schistose rocks, carbonate-cemented sandstone, agate, and chert in the stratified parts of the deposits might react deleteriously if used in cement. Of these, only the first four deserve serious consideration, because the others occur in only insignificant amounts.

\section{ICE-MARGINAL OUTW ASH-CHA N NEL DEPOSITS}

\section{NAME, LOCATION, AND AREAL EXTENT}

I) uring deglaciation of the last ice lobe, melt water cut many outwash channels along successive positions mostly marginal to the southwest side of the ice lobe. Outwash of varying thicknesses was deposited in these channels. Some very thin outwash deposits in small or indistinct channels have not been differentiated on the map from ground moraine. 
The outwash channels are especially prevalent in the Souris River loop area, though large ones are also incised in the ground moraine west of the Des Lacs River and some are southeast of Velva. One outwash channel is cut in the Max moraine. Inasmuch as the outwash deposits are intimately related to the channels in which they lie, a fairly detailed description of the channels themselves is necessary. For convenience each channel is called by the name of the intermittent stream that flows along its floor.

The channels in the Souris River loop area are not only the most plentiful but are also the longest. Some channels, like the combined West Cut Bank-Spring Coulee channels, extend 50 miles across the mapped area and head many additional miles farther north in Canada. In places, the larger channels spread out to widths of 1-3 miles, but commonly they are $1 / 4-1 / 2$ mile wide and are spaced 2-5 miles apart. Most of the channels in the Souris River loop, however, are considerably shorter and narrower, and many are so small and indistinct that they can be delimited only on aerial photographs. A maze of small bifurcating channels a few miles east of Minot in the southern part of the Souris River loop area probably were not all formed marginal to the ice edge but are included in this unit. Many of these are very indistinct and contain little outwash.

Several segments of ice-marginal outwash channels are parallel to the diversion channels southeast of Velva. Although they are nearly identical in form to the nearby diversion channels, they are not diversion channels because most of their floors slope toward the northwest-in the direction opposite from that of the diversion channels. For example, near Krueger Lake, in the northwest part of Sheridan County, the floor of an outwash channel is at an altitude of 1,660 feet. From this point, the outwash-channel system, which consists of several branches, slopes to the northwest, and where it joins the Velva diversion channel about 3 miles southeast of Velva the altitude of the ice-marginal channel floor is about 1,600 feet. The floor of the icemarginal channel near Kief, at the southern edge of McHenry County, is at an altitude of about 1,550 feet and likewise slopes to the northwest. This channel apparently was used after the channel segment of Krueger Lake was abandoned. The reason for the direction of slope of these channels is not clear.

There are only a few channels in the area between the Souris and Des Lacs Rivers, and on the groundmoraine plain between the Souris River and the Max moraine. However, there are scattered remnants of outwash terraces near the tops of some tributaries to the Souris River north of Kongsberg in the southern part of McHenry County. These water courses were originally used as melt-water channels and later deepened by erosion. The tributaries that head along the escarpment of the Max moraine to the northwest in Ward County do not contain outwash, although some of them may have been carved partly by glacial melt water.

The ground-moraine plain west of the Des Lacs River is cut by outwash channels that range widely in size but lack the remarkable southeast orientation of most of the channels within the Souris River loop. It is likely that these channels were not everywhere ice marginal. The one or two larger channels, which seem to have been the main collecting water courses for numerous small tributary channels, are many miles long and commonly 1-2 miles wide. The tributary channels are commonly no more than one-tenth mile wide.

\section{TOPOGRAPHY}

The deposits are commonly on both the floors and walls of the outwash channels. In places, they form well-defined terrace remnants flanking the walls; in other places, they form a fairly smooth blanket extend. ing up the channel walls from the floor. Deltas built near the mouths of some channels are included with the outwash-channel deposits because of the difficulty of distinguishing the deposits. One such delta was deposited at the mouth of Strong Run channel in the northern part of Burke County, about 11 miles north of Bowbells, where outwash was carried into the waters of the diversion channel. This deposit forms a broad delta that extends about 1 mile beyond the walls of the outwash channel. It widens laterally to about 3 miles, whereas the deposits within Strong Run channel are only about one-fourth mile wide. Some deltas deposited in glacial Lake Souris cannot be distinguished from other shoreline deposits and have been included with the deposits of glacial Lake Souris.

Small Recent intermittent streams have incised narrow steep-walled water courses into the floors of some of the larger channels and, partly or completely, removed narrow strips of channel deposits. Cut Bank Creek, Spring Coulee, Little Deep Creek, and Egg Creek, are the most prominent of these intermittent streams in the Souris River loop area. Stony Run is the most conspicuous Recent stream west of the Des Lacs River. Although alluvium and ground moraine are the surface deposits along the floors of these inner channels, they are too small in area to be separated on the map. Also included with the channel deposits are slopewash from the channel walls and small patches of ground moraine along channel floors where there was no deposition of outwash deposits.

Most of the well-defined outwash channels in the Souris River loop area are roughly parallel to each 
other and normal to the regional slope-that is, the regional slope is northeast and the trend of the channels is southeast. Therefore, the channels are progressively lower from southwest to northeast. This characteristic is well shown on the topographic map of the Lansford SE quadrangle. A few channels appear to occupy preexisting sags, but most have been eroded by melt waters of the last glaciation. Smaller cross channels generally connect the large southeasttrending channels. The channel pattern is somewhat regular in the area west of the Des Lacs River, but the interconnected channels mostly lack the definite pattern of those in the Souris River loop area. In general, the trend of the larger channels west of the Des Lacs River is eastward. Minor channels, heading along the northeast escarpment of the Max moraine, join the main channels nearly at right angles.

Most of the channels are remarkably shallow in comparison to their width. Some that are one-fourth to one-half mile wide are less than 10 feet deep and they can scarcely be detected in the field. Delimiting the channels and discerning outwash in channels are greatly facilitated by the use of aerial photographs. Slight textural differences betwen the channels and the surrounding ground-moraine plain, as well as vegetational changes, show much more clearly on aerial photographs than on the ground. The deeper channels, such as Cut Bank Creek, Spring Coulee, Little Deep, and Egg Creek, are 20-30 feet deep along much of their courses.

Two types of channel profiles are rather well defined. The more common type has a gently rounded bottom that slopes uniformly up to the top of the channel walls. It commonly contains little outwash. The other type has gently sloping walls but has a flat floor underlain by outwash. Thus, by cursory examination of the channel profile, or by use of photographs, it can generally be determined whether the outwash is relatively thick or thin.

In places, low terrace remnants flank the walls of both the rounded-bottom and the flat-floored types of channel. Some channels contain undrained depressions, some of which are as much as 1 mile long and cover the entire width of the channel floor. Most of the depressions are less than 5 feet deep, and during periods of heavy precipitation they contain intermittent ponds or marshes.

The floors of many outwash channels are 5-20 feet above those of other channels with which they join. The hanging channels were abandoned by melt waters in favor of lower channel outlets. Well-defined scarps that separate the hanging channels from the lower ones are useful in determining the channel history. Most hanging channels contain more outwash than the lower ones with which they are connected. Deposition of outwash was presumably more favorable during the earlier stages of channel life than during later stages. During the earlier stages the streams were overloaded with outwash; later, owing to a lowered baselevel caused by ice withdrawal, sufficient water probably was present in proportion to the amount of outwash to erode most of the channel deposits that had originally been laid down.

The gradients of the different outwash channels range considerably, although those within any given area are generally similar; the long, well-oriented channels in the Souris River loop area have nearly equal gradients for their total lengths, although individual segments of a single channel differ considerably. The average gradient of Little Deep channel within the mapped area is approximately 4.7 feet per mile over a distance of 35 miles. The gradient flattens slightly to about 4.4 feet per mile in the lower 15 miles. The combined West Cut Bank-Spring Coulee channel, which is 49 miles long, has an average gradient of slightly more than 3.3 feet per mile. The part in the vicinity of Mohall and Lansford is approximately 4 feet per mile. The lower 13 miles is slightly less than 2 feet per mile. Because of the short length of most of the interconnected channels in the southern part of the Souris loop area, the gradients of those channel floors are difficult to determine accurately. Most, however, appear to be gentler than those of the long channels to the north. Stony Run, in northeastern Burke County, has a gradient of slightly less than 6 feet per mile in 11 miles of its course between its mouth and a point directly south of Flaxton. Most of the other large channels west of the Des Lacs River have considerably flatter gradients. In fact, some channel segments, like those 5-8 miles south of Flaxton, appear to be nearly flat.

The channel deposits range in thickness from an indistinct veneer which has now become part of the soil profile to 20 feet. In general, deposits more than 5 feet thick consist of sand and gravel, whereas the thinner deposits consist of silt and clay. Numerous gravel pits have furnished a fairly good indication of thicknesses. Many pits have been excavated to the bottom of the deposits but others do not extend below the water table and furnish minimum thicknesses only. In a few places, thicknesses have been obtained by drilling or from water-well data.

Deposits in the large southeast-trending channels in the Souris River loop area are generally thickest near the mouths of the chamnels. Hence, for a distance of 
3-5 miles upstream from the channel mouths the deposits are 5-15 feet thick. Farther upstream they are rarely more than 10 feet thick and commonly are less than 5 feet thick, except in local terrace remnants. Only a thin veneer generally is present near the channel heads.

Only scattered deposits are more than 5 feet thick in the bifurcating maze of channels in the vicinity of Surrey in the eastern part of Ward County. Most of these channels have gently rounded bottoms scoured in till, and probably only a thin veneer of outwash was ever deposited.

Channels southeast of Velva are mostly flat bottomed. Exposures are very few, but several feet of outwash is indicated in most places. One of the thickest extensive deposits of channel outwash west of the Des Lacs River is a deltalike deposit at the mouth of Stony Run in the northeast part of Burke County. It is at least 10 feet thick in many places and locally may be as much as 20 feet. Elsewhere west of the Des Lacs River, channel outwash is rarely more than 10 feet thick and in most places is less than 5 feet. The main trunk channels in the area between Bowbells and Flaxton contain the thickest deposits. Elsewhere to the west only scattered deposits of small size attain a thickness of 5 feet.

\section{STRATIGRAPHIC POSITION AND AGE}

The deposits, which were laid down by melt waters of the last ice sheet, are underlain nearly everywhere by till. A few deposits, such as the deltas previously described, probably intertongue with and overlie glaciallake deposits and diversion-channel deposits. In places southeast of Velva, outwash-channel deposits are overlain by alluvium from tributaries that head near the escarpment of the Max moraine. Other channel deposits are overlain by thin slope wash, which has not been differentiated on the map.

Contacts between outwash-channel deposits and the adjacent ground moraine are generally sharp but are generally concealed by a thin veneer of slope wash. Commonly, the configuration of the topography helps in locating the contact. For example, in flat-floored channels, the contact between the outwash and the ground moraine is at the break in slope between the valley wall and floor of the channel. The back edges of the terrace remnants in the channels likewise, are generally marked by an abrupt break in slope.

\section{GRAIN SIZE, SHAPE, AND IITHOLOGIC COMPOSITION}

Material in the outwash-channel deposits ranges in size from clay to boulders, but sand and fine to medium gravel predominate. Thus, in general, the grain size is smaller than that of the river-terrace deposits. Sand and larger material generally occur separately from silt and smaller material. Sand and gravel usually underlie terrace remnants along the channel walls or fairly thick flat-surfaced deposits along channel floors. Silt and clay rarely underlie terrace remnants; they generally form thin deposits along round-bottomed channels. Therefore, the grain size of the deposits also can be predicted by the surface profile of the channel. Sporadic boulders are exposed on the floors and walls of channels that contain only minor amounts of outwash. They probably are lag concentrates derived from the till into which the channels were scoured. Stony Run channel, as well as other channels near the Des Lacs River, contain boulder concentrations on their floors. Some of these boulders are as much as 4 feet long. In contrast, boulders a foot long are the maximum size usually found in the outwash deposits, and probably are the largest size that the channel melt waters were able to transport.

In the Souris River loop area, the lower reaches of the larger channels contain most of the sand and gravel outwash. In general, grain size is progressively finer down channel. Where the channel melt waters emptied into glacial Lake Souris, therefore, sand and fine gravel were deposited; a few miles upstream less sand and more fine and medium gravel were deposited. Near the heads of the channels, however, as well as locally in other parts of the channels, little or no sand and gravel were deposited and there is only a thin veneer of silt and clay. Likewise, only thin veneers of silt and clay are in the braided channel system in the vicinity of Surrey, except for local small patches of sand and gravel. In the area west of the Des Lacs River, sand and gravel were deposited locally along the floors of the larger channels; but material larger than sand is scarce in the smaller channels in this area and in the wide but shallow channels south of Flaxton.

Cobbles and boulders are generally subangular, in contrast with more rounded cobbles and boulders in terrace and diversion-channel deposits. Inasmuch as there was little glaciofluvial abrasion on these boulders, there was little opportunity for them to become as rounded as those in the terrace deposits. The gravel in the outwash-channel deposits is subrounded to subangular and similar to gravel of the same size in the terrace deposits.

The lithologic composition of the deposits is similar to that of the river terraces, diversion terraces, and ground-moraine fraction of corresponding grain size. The pebble counts shown below made on gravel-sized (0.05-3 inches) material indicate that carbonate rock predominates, and granite, granitic gneiss, and other granitoid rocks are next most abundant. Quartzite, 
Pebble counts on gravel-size material showing lithologic composition of outwash-channel deposits in Bottineau, Renville, and Ward Counties, N. Dak.

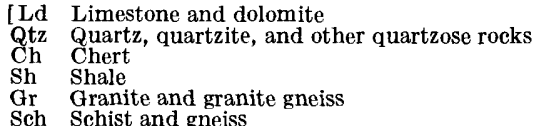

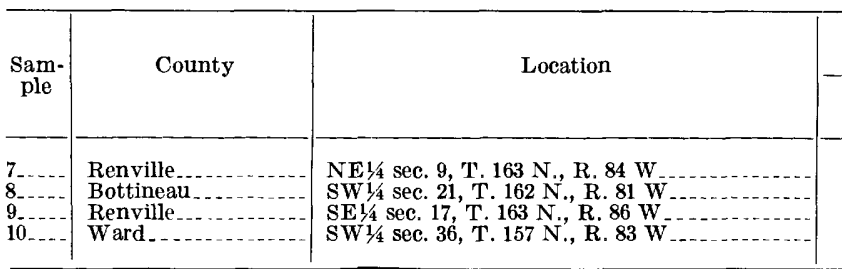

basic fine-grained rocks, chert, schist, shale, sandstone, and clay ironstone are minor constituents. Carbonate and granitic rocks are approximately equally abundant in cobble size (3-10 inches in diameter). Most boulders are granitic. The sand and silt fractions are mostly quartz; carbonate rocks and feldspars are next in abundance.

Till balls are absent in most deposits but are numerous locally. In a gravel pit north of Norwich, in the eastern part of Ward County, about 25 percent of the material consists of nearly spherical balls of till, $2-4$ inches in diameter and identical in composition to the till of the ground moraine. These till balls are not armored with pebbles, hence, they must have been transported only a short distance.

Lignite chips are fairly abundant in many parts of the deposits, but, unlike the large pieces found in some terrace deposits, they are generally less than one-half inch long. Despite their small size most chips are shiny and fresh.

The material generally is moderately well to well sorted. Sand and gravel usually are mixed togetlıer, although, in places, individual beds consist entirely of sand. In a few places, beds consist entirely of fine gravel of nearly uniform grain size. Silt and clay, where present, are generally well intermixed.

\section{INDURATION, CEMENTATION, AND WEATHERING}

The deposits are not indurated or cemented, except for local partial cementation by caliche in the upper 2-4 feet. They are weathered only to the extent of other stratified deposits already described.

\section{BEDDING AND SORTING}

The sand and gravel is indistinctly to well bedded. Most beds are 1-3 feet thick and are generally essentially horizontal. Some beds are well crossbedded, especially deltaic deposits near channel mouths.
Ogr Other granitoids

Af Acid felsites, porphyrys and rhyolite

M Miscellaneous sandstone, siltstone, clay and clayballs, coal, limonite and ironstone argillite.]

\begin{tabular}{|c|c|c|c|c|c|c|c|c|c|}
\hline \multicolumn{9}{|c|}{ Composition (percent) } & \multirow{2}{*}{$\begin{array}{l}\text { Num- } \\
\text { ber of } \\
\text { pebbles } \\
\text { counted }\end{array}$} \\
\hline Qtz & $\mathrm{Ch}$ & $\mathrm{Sh}$ & Gr & Sch & Ogr & Af & $\mathrm{Bf}$ & $\mathbf{M}$ & \\
\hline $\begin{array}{r}5.3 \\
5.6 \\
11.0 \\
2.5\end{array}$ & 2. 6 & 7.4 & $\begin{array}{r}15.8 \\
9.3 \\
16.3 \\
16.5\end{array}$ & 1.3 & $\begin{array}{r}13.2 \\
1.8 \\
7.2 \\
21.5\end{array}$ & 1.8 & $\begin{array}{l}7.9 \\
1.8 \\
5.5 \\
5.1\end{array}$ & $\begin{array}{r}10.5 \\
1.9 \\
10.9 \\
2.5\end{array}$ & $\begin{array}{l}38 \\
54 \\
55 \\
79\end{array}$ \\
\hline
\end{tabular}

In the northern part of Bottineau County in the vicinity of Landa a channel was cut parallel to the present Souris River valley for a distance of about 10 miles. One end of the channel joins the Souris River valley about 3 miles southeast of Westhope and the other end joins just north of the International Boundary. The channel is floored with sand and gravel more than 15 feet thick in places. Its gradient suggests that water flowed toward the south and emptied into the valley of the Souris River at an altitude of about 1,450 feet, or about 65 feet lower than the maximum height of glacial Lake Souris in this vicinity. The explanation for this anomalous situation is not entirely clear.

As discussed previously under "Ground Moraine," a small lobe of ice appears to have occupied the area east of the Souris River valley, in the northern part of Bottineau County, until after glacial Lake Souris had been lowered at least 65 feet below its maximum height. At that time the outwash channel was probably cut marginal to this lobe of ice, which was melting back toward the northeast. It is not clear, however, how the lake could have drained to an altitude of 1,450 feet before this area was uncovered from beneath the ice, inasmuch as the lowest spillway floor at the southeast end of the lake is at an altitude of 1,510 feet. Therefore, drainage must have been to the north, down the Souris River valley. But the margin of the main lobe of ice was receding to the northwest, whereas, if the small lake east of the river was connected with the main ice body, it is inferred that the Souris River valley north of the International Boundary must have been occupied by ice.

The channel appears to have been a diversion channel or spillway when ice locally blocked the Souris River valley. However, its gradient is to the south and the large amount of sand and gravel it contains can only be explained as material from an outwash channel. Moreover, its altitude is too low to have allowed lake water to accumulate to a height of 1,510 feet northwest of Westhope. 


\section{ORIGIN AND TYPE OF DEPOSIT}

The deposits accumulated in channels formed successively at the southwest margin of a northwestwardretreating ice lobe. As the southwest side of the ice lobe melted northeastward, each channel was abandoned successively in favor of lower channels closer to the ice margin and downslope to the northeast. Undrained depressions in the channel floors appear to mark places where ice blocks buried in the till underlying the channels did not melt until after the channels were abandoned. The large southeast-trending outwash channels in the Souris River loop area have very few side tributaries. The question arises as to how melt water drained into these channels when the ice margin stood between them. In places, water flowed over the intervening ground moraine, as shown by the fact that the surface of the moraine is marked by an indistinct braided rill pattern. In most places, however, the ground moraine between the channels is pitted by undrained depressions to the very edge of the channel walls and it is unlikely that much melt water flowed across the ground moraine. Moreover, in most places, melt water could not have flowed into an already established channel southwest of the ice margin because of a rise in slope in that direction. The writer favors the explanation that more than one channel was occupied at the same time in any one area. Thus, one channel might have been draining the melt waters along the side of the ice, whereas one or more channels might have been flowing roughly parallel to it in the ice itself. At first these water courses may have been entirely in the ice, but upon further melting and erosion, they were lowered to the ground and scoured channels in the underlying ground moraine. In this manner a block of ice situated between a channel and the ice margin would become detached from the main ice sheet. Melt water from this ice block could then drain into either bordering channel. Some support for this supposition is furnished by the fact that there are a fow cross channels that connect with the southeast-trending channels. The floors of these cross channels commonly hang above the floors of the southeast-trending channels, yet they are commonly slightly higher at intermediate points than at either end. Such cross channels must have had reverse drainage, a condition that is likely if water in two southeast-trending channels flowed at the same time but unlikely if only one channel was in use. The fact that outwash extends to the top of both channel walls can also be best explained if it is postulated that both channel walls were marginal to the ice that partly supported the outwash.

In the complex braided network of outwash channels in the vicinity of Surrey, in the eastern part of Ward
County, it appears that several channels may have carried melt waters simultaneously and that the melt waters flowed between many blocks of ice. If blocks of ice had not been present, probably only a few large channels would have formed at successive positions marginal to the ice because of the northeast slope of the ground surface.

\section{ENGINEERING GEOLOGY}

The physical characteristics of outwash-channel deposits are similar in many respects to those of diversion-channel deposits. Permeability is high in the sand and gravel and special problems of leakage will probably arise if canals or dams are built in this material. Permeability is moderate to low in the silt and clay. Because highly impermeable till usually underlies the deposits and forms the channel walls, drainage is generally poor except down the channel. Many of the flat-bottomed channels contain marshes and intermittent ponds.

Road cuts in the sand and gravel parts of the deposits are fairly stable at moderate to high angles. Likewise, the sand and gravel provide road beds of high foundation strength.

The deposits provide very large sources of sand and gravel, and they are scattered rather fortuitously over most of the mapped area. Pits have been dug in many places to obtain road-surfacing materials, but the available reserves have hardly been touched. Little or no material in the deposits will react chemically in a deleterious manner in cement, but some material is physically deleterious, chiefly lignite chips and till balls.

All the deposits can be easily worked with hand or power tools. Because of the high water table, some difficulty may arise in excavating the deeper parts of the deposits.

\section{GLACIOFLUVIAL DEPOSITS, UNDIFFERENTIATED AS TO ORIGIN \\ NAME, LOCATION, AND AREAL EXTENT}

Stratified glacial deposits of uncertain origin are scattered throughout the mapped area. Although several types may be represented, all are mapped as glaciofluvial deposits undifferentiated as to origin. Deposits range in size from small features a few hundred feet in diameter to large features such as a deposit southeast of Velva that is more than 10 miles long and 1 mile wide. Other large deposits are in Ward, Renville, and McHenry Counties.

\section{TOPOGRAPHY}

Most deposits stand 15 feet or less above the surrounding terrain, and many have little or no definite 
topographic expression. Some are low ridges, some are mounds, and some are nearly flat sheetlike bodies.

THICKNESS

The deposits range in thickness from a few feet to perhaps 50 feet; the average is probably about 15 feet.

\section{STRATIGRAPHIC POSITION AND AGE}

Most of these stratified deposits are not overlain by younger deposits, except locally by a thin veneer of Recent alluvium. Nearly all are underlain by till. They are glaciofluvial in origin and were laid down during the deglaciation of the last substage.

\section{GRAIN SIZE AND LITHOLOGIC COMPOSITION}

Most of the deposits consist of fine gravel, sand, and silt. The lithologic composition is similar to other outwash and stratified ice-contact deposits in the area.

\section{BEDDING AND SORTING}

Almost all of the deposits are indistinctly to distinctly bedded. Beds range in thickness from a few inches to a few feet. Generally the range in grain size in any one area is small, although some deposits range widely in grain size.

\section{INDURATION, CEMENTATION, AND WEATHERING}

Induration or cementation is rare to absent in most deposits, though the upper few feet of some deposits are partly cemented with caliche. Rocks show little or no weathering, except where biotite-rich gneiss is disintegrated.

\section{ORIGIN AND TYPE OF DEPOSIT}

Many deposits appear to be ice contact in origin. Some are probably outwash, but the origin of others is very obscure. Speculative origins for some deposits are discussed under the heading "Special localities."

\section{SPECIAL LOCAIITIES}

One deposit whose areal extent is moderately well defined lithologically but poorly defined topographically is on the ground-moraine plain in the northern part of Renville County, just southwest of the town of Tolley. For the most part, it forms the northeastern flank of a broad shallow flat-floored depression on the ground-moraine plain. The deposit appears to consist of sand and fine grarel; gravel is confined to the southern tip. In most places, the deposit is underlain by till at a depth of less than 10 feet; in some, a greater thickness is indicated. Perhaps during the recession of the ice front a separate block of ice remained in the shallow flat area to the southwest, and sand and gravel outwash was then deposited on a narrow strip of till plain, bounded on the southwest side by an isolated ice block and on the northeast side by the main ice sheet.
Another type of deposit is a series of northwesttrending subparallel ridges and knolls, 10-30 feet high, west of the Souris River in the southern part of Renville County. The deposit consists chiefly of sand and fine gravel, but in places it contains considerable amounts of intermixed till. This deposit is probably ice contact in origin and formed during recession of the ice from that area.

Directly east of the deposit described above, across the Souris River, is a southeast-trending deposit about 3 miles long and one-half mile wide. It consists mostly of sand and has little topographic expression although its surface has been extensively modified by wind. It may be the remains of an outwash plain.

An ill-defined area northeast of the Des Lacs River along the western edge of Renville County and about 3 miles east of Donnybrook, consists of closely spaced knobs and irregular short ridges, 5-15 feet high, composed chiefly of poorly sorted stratified material. Many of the knobs and ridges are capped by coarse gravel underlain by fine gravel, sand, and silt. Undrained depressions, underlain by till, occupy most of the area between the knobs and ridges. In general appearance and composition the deposits appear to be a kame field. Yet in configuration and composition they resemble, except for their indistinct outline, some features in the northeastern part of Ward County that are mapped as "End moraines in Souris loop area."

An area in the south-central part of McHenry County, about 4 miles north of Simcoe, is covered by sand and fine gravel. The sand and gravel may have been partly derived from overflow of outwash channels in this area.

Several linear belts of sand and fine gravel in the southern part of McHenry County, between Butte and Bergen, show collapsed bedding. In most places, the deposits rise only slightly above the surrounding terrain; but in some places, their generally uneven surface is actually lower than the adjacent topography. Their surfaces are generally gently undulating. Southeast-trending linear ridges and grooves modify the deposits, whence it appears that the deposits were ice contact in origin and were later overridden by ice. It is not clear why no till was deposited on them.

\section{ENGINEERING GEOLOGY}

Because of the fairly wide range of deposits in this unit, there is a fairly wide range in engineering properties of the material. Some generalizations, however, can be made.

Permeability in most deposits is high. Deposits that rise above the surrounding terrain are generally well drained, whereas those that do not are commonly 
poorly drained because of the impermeability of the underlying till.

Steep slopes in most deposits erode easily and have low stability. Well-compacted material has moderate to high foundation strength. All deposits are easily worked with hand or power tools and some are sources of fairly clean sand and fine gravel.

\section{DFPOSITS OF GLACIAL LAKE SOURIS}

NAME, LOCATION, AND AREAL EXTENT

Lake Souris was an ice-marginal lake that enlarged northwestward as the ice front receded in that direction. Deposits accumulated on the lake bottom from the discharge of diversion channels and ice-marginal outwash channels, and from discharge directly off the ice front. The lake bed lies partly in Canada and partly in the United States. Its deposits in the United States (pl. 15) extend about 85 miles in a northwesterly and about 45 miles in a southwesterly direction. The part of the lake bed mapped in detail (pl.1) is mostly west of the east loop of the Souris River; it is about 60 miles long in a northwesterly direction and about 30 miles across.

\section{TOPOGRAPHY}

The lake bed has a very flat surface which slopes gently toward the middle of the lake from both the west and east shorelines. Altitude of the lake bed ranges from about 1,540 feet in the extreme southeast part of the mapped area to about 1,430 feet near the Souris River in the vicinity of Upham. Large areas, however, are nearly flat. For example, the part of the lake bed near the west shoreline between Granville and Denbigh, a distance of about 12 miles, has a total relief of less than 20 feet and a local relief of less than 10 feet. Owing to partial draining of the lake through the spillway at the southeast end of the lake at the same time as the lake followed the receding ice front back and increased its areal extent, the shoreline is higher at the south end of the lake than at the north end. Thus south of the Souris River and east of Karlsruhe, the altitude of the shoreline is about 1,540 feet, whereas north of the Souris River, it is between 1,520 and 1,500 feet. In most places, the altitude of the shoreline is between 1,510 and 1,515 feet.

A channel that is cut 5-15 feet deep in the lake deposits extends from Buffalo Lodge Lake southward to the Souris River valley north of Verendrye. Near the river valley, it turns eastward and for about 5 miles borders the north wall of the Souris River valley about 25 feet above the alluvial floor. Its position here is that of a terrace graded to the Souris River at the time it was incised. Its floor ranges in altitude from about 1,485 feet near Buffalo Lodge Lake to about 1,500 feet near the Souris River. However, its drainage direction is unclear; drainage might have been reversed during its life.

Sinuous sags that are several miles long modify the otherwise flat surface between Denbigh and Bantry and also in the vicinity of Westhope. Some of the sags are believed to be buried channels cut in the till beneath thin lake beds. The origin of others is less clear.

In places, a fairly pronounced southeast-trending lineation characterizes the surface of the deposits. Much of the lineation is due to the presence of elongate dunes; but part, as in the ricinity of Bantry, is in silt deposits that appear to be only slightly modified. This lineation may reflect existence of linear ridges and grooves in the till beneath the lake deposits. Likewise, two concentric scarps about 15 feet high that occur west of Bantry may reflect the underlying till surface.

Several lakes partly fill depressions in the lake deposits in the area northeast of Granville and in the vicinity of Denbigh. The largest of these, Buffalo Lodge Lake, is about 3 miles long and 2 miles wide. It is believed to be very shallow. Depressions occupied by the lakes are usually steep sided and appear to be kettle holes. Old shore lines, as much as 15 feet above the present water surface of the lakes, indicate that, not too long ago, the lake surfaces were considerably higher than they are now. Other very shallow undrained depressions, most prevalent near the shoreline of the glacial lake, are swampy during wet years.

More conspicuous than the above-mentioned depressions are dunes and local "blowout" areas. Dunes are mapped separately, but blowout areas are included with the lake deposits. The areas contain many steep-sided depressions, commonly 5-8 feet deep, that were eroded by winds. These "blowouts" are at least partly the source of the dunes and are most abundant on the west sides of conspicuous dune areas.

\section{THICKNESS}

The lake deposits range from a featheredge to a known thickness of 73 feet that was penetrated by an anger in a hole 5 miles southwest of Denbigh, in the SW1/4 sec. 25 , T. 156 N., R. 78 W. Evidence from drilling in other parts of the mapped areas and from natural exposures indicates that 73 feet is near the maximum thickness. In general, the deposits appear to be much thicker in the southern half of the mapped area than in the norther'n half. Northward from the vicinity of Upham they appear to thin rather abruptly; near Westhope they are generally less than 5 feet thick; in most places they are about 3 feet thick. Till is exposed locally along the valley walls of the Souris River for 15 miles south from the International Bound- 
ary; small patches of till are poorly exposed elsewhere in the northern half of the area. Because of the difficulty of delimiting these till areas, they are not shown on the map.

\section{STRATIGRAPHIC POSITION AND AGE}

The lake deposits nearly everywhere lie on moderate to thick till. At a hole 3 miles northeast of Granville, in the $\mathrm{NW} 1 / 4$ sec. $1, \mathrm{~T}$. $155 \mathrm{~N}$., R. $79 \mathrm{~W}$., an auger penetrated 10 feet of lake deposits and 47 feet of till before striking bedrock. Bedrock was not encountered in an auger hole 100 feet deep in the SW1/4 sec. $25, \mathrm{~T}$. 156 N., R. $78 \mathrm{~W}$. The upper 73 feet of this hole was in lake deposits and the remainder was in unoxidized bluish-gray till. In the northern part of the deposits, near Westhope, till is at an average depth of 3 feet. A lag concentration of many boulders, far more numerous than in the till, marks the contact between the two deposits.

Sand dunes overlie the lake deposits and are derived from them. Along the Souris River in the southern half of the lake area, alluvium probably nearly everywhere overlies the lake deposits. In the northern part of the area, especially near the International Boundary, the Souris River has cut through the lake deposits, and the alluvium rests on till. Kames and glaciofluvial deposits, undifferentiated as to origin, are probably contemporaneous with early lake deposits.

Glacial ice-marginal outwash-channel deposits intertongue with the lake deposits near the shoreline. Some of the ice-marginal outwash channels discharged into the lake area after the lake had receded some distance from the high-stage shoreline; in places, their deposits extend several miles into the lake area. However, because of the difficulty of distinguishing them from lake deposits of nearly identical composition, they have been included with the lake deposits. Other channels appear to have been in existence only during the high stage of the lake, and their outwash presumably was deposited as deltas near the mouths of the channels. However, owing to reworking by wave action and because of similarity of lithologic composition and grain size between these deposits and near off-shore lake deposits, they also have been included with the lake deposits. An arbitrary boundary that marks approximately the high shore of the lake separates ice-marginal outwash-channel deposits from lake deposits at these places.

\section{GRAIN SIZE, SHAPE, AND LITHOLOGIC COMPOSITION}

Sand is the predominant size fraction, silt is probably next most abundant, and fine gravel is third. Lake clays locally underlie the surface deposits but are nowhere known to be exposed. Sand is the most abundant constituent where the deposits are the thickest, as in the southern half of the area. Fine gravel is less widespread than sand and is confined chiefly to the southern half of the lake area. It extends out from the mouths of some of the larger outwash channels and borders the southeast valley wall of the Souris River, eastward from a point about 9 miles east of Verendrye for a distance of several miles; it also borders the east valley wall of the river northward from Towner for a distance of about 2 miles and forms two narrow northtrending belts between Turner and Denbigh. Areas of silt alternate with smaller areas of sand in the vicinity of Bantry. In places the material is probably plastic enough to be classed as a silty clay, but banded lake clays are nowhere exposed. In drilling near Bantry, however, the Bureau of Reclamation penetrated banded lake clays underlying coarser surface deposits. A thermal analysis suggests that the banded clay is chiefly illite.

Figure 12 shows a sieve analysis of a sand sampled at a depth of 20 feet, in an auger hole 3 miles southwest of Denbigh in the SW1/4 sec. 25 , T. 156 N., R. $78 \mathrm{~W}$.

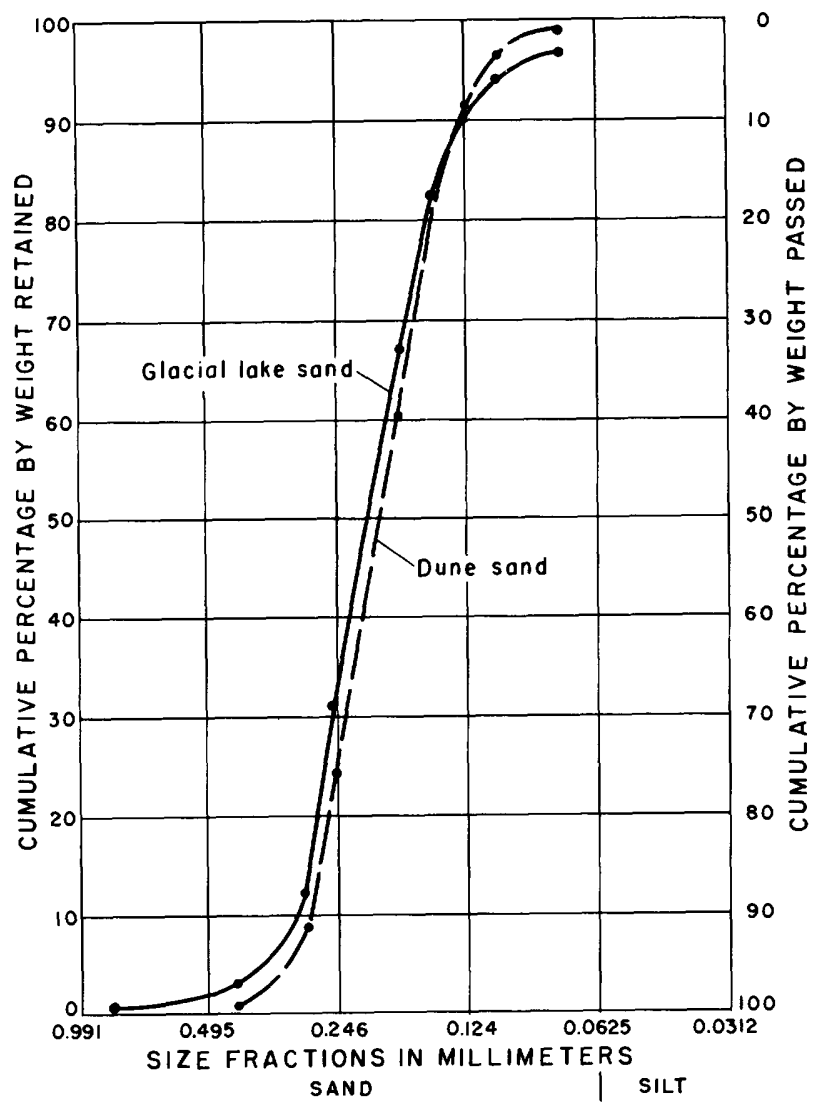

Figure 12.- Size analyses of glacial-lake sand taken from an auger hole at a depth of 20 feet. in the SW $1 / 1$ sec. $25, T$. 156 N., R. 78 W. and of dune sand taken 4 miles southwest of Denbigh, in the SW $1 / 4$ sec. 36 , T. 156 N., R. 77 W. 
At a depth of 40 feet the sand was generally coarser and its range in grain size was greater than at 20 feet. At both depths the sand is predominantly quartz. Minerals that have a specific gravity greater than 2.8 constitute 2.54 percent of the sample taken at 20 feet and 2.56 percent of the sample taken at 40 feet. Most of the quartz grains in both samples are sharply angular and clear. Some quartz grains, however, are frosted and subrounded. The feldspar and other mineral grains are mostly rounded. Lignite chips slightly larger than the sand grains are relatively abundant in both samples. The upper 30 feet of the sand is tan, as though oxidized; below 30 feet the sand is dark gray, as though unoxidized. The water table was at a depth of 6 feet when the hole was drilled; therefore, if the color of the upper sand is due to oxidation, the water table must have once been 24 feet lower. The lithologic composition of the fine gravel is similar to that of gravel of the same size in the ice-marginal outwash channels; carbonate rocks are most abundant and granitic rocks are next. The gravel, in general, is considerably more rounded than the sand; most of it is subangular to subrounded. The lithologic composition of the silt was not examined.

Small chips of lignite, usually slightly larger than the material with which they are associated, are relatively abundant in the sand and fine gravel. Although the chips are small and many are near the surface, they are mostly shiny and unweathered.

\section{BEDDING AND SORTING}

Because the sand is so uniform in size, bedding is obscure except in the coarser fraction. Bedding is much more distinct in the fine gravel, especially in deltaic deposits near the mouths of the glacial outwash channels, where there is local conspicuous crossbedding. The silt is massive, except locally where it forms indistinct beds.

INDURATION, CEMENTATION, AND WEATHERING

A little caliche loosely cements the upper 2-4 feet of some deposits of fine gravel, but it is of minor areal extent. Most of the material is essentially unweathered, but some of the carbonates, feldspar, and black minerals of sand size and smaller are some what altered. Their surfaces are dull and pitted. About the only pebbles that show any effects of weathering are granitic rocks rich in biotite.

\section{UNCLASSIFIED DEPOSITS}

Three deposits of fine gravel and sand in the area north of Towner and between Towner and Denbigh appear to be some sort of ice-contact deposit. They have not been differentiated from the lake deposits because they were completely covered by the lake waters and their original landforms probably have been modified. A deposit that extends north from Towner for about 3 miles has a very abrupt scarp about 25 feet high where it is in contact with the alluvium of the river valley. Its surface is flat and grades back imperceptibly into sand in a distance of less than one-half mile to the east. Two other deposits, west of the river, are indistinct north-trending ridges, $5-15$ feet high, less than 1 mile long, and about one-fourth mile wide. They are chiefly of fine gravel and sand but contain medium gravel and cobbles. Rocks this size indicate that the deposits probably are not beaches.

\section{ORIGIN, TYPE OF DEPOSIT, AND GEOLOGIC HISTORY}

The deposits were laid down in the water, or on the shore, of glacial Lake Souris during deglaciation of the last ice. The deposits were derived from diversion channels, ice-marginal glacial-outwash channels, melt water flowing down the Souris River valley, and drainage off the ice sheet itself. The lake expanded progressively in size from south to north.

Melt waters drained successively through the diversion channels that headed along the Souris River valley between Velva and Verendrye and discharged into the southern part of the lake area. As the ice melted back toward the north and northwest, the northern edge of the lake followed the ice front back, and the lake area expanded. During early stages the surface of the lake reached a maximum altitude of about 1,540 feet within the mapped area.

The diversion channels deposited chiefly sand in the southern part of the lake area. After the ice front had retreated to a point just north of the Souris River, where the river bends from east to north, melt water that was coming down the Souris River valley was no longer diverted through the diversion channels to the southeast but was discharged into the lake area a few miles east of Verendrye. Fine gravel along the south bank of the Souris River valley in this part of the lake area was probably deposited by these melt waters. About this time the floor of the Girard Lake spillway (see pl. 15), at the southeast end of glacial Lake Souris, was incised to an altitude of about 1,520 feet and the surface of the lake was lowered to this level.

As the ice lobe receded still farther northwest, numerous ice-marginal outwash channels emptied into the lake area at successive places along its western shoreline. Fine gravel and coarse sand were deposited in deltaic beds at the mouths of these outwash channels and in narrow belts that extended outward as much as several miles over the earlier lake deposits. These belts of material indicate that activity in some out- 
wash channels continued beyond the time when the lake was at its highest level in that area. The remaining sand and the silt were carried farther out into the lake.

By the time the ice edge had receded to a line near the International Boundary, the floor of the Girard Lake spillway had been cut to an altitude of about 1,510 feet and the lake level had been lowered correspondingly. Upon further recession of the ice front, the lake started draining to the north down the Souris River valley, and when the floor of this spillway reached an altitude of about 1,430 feet, all the water in that part of the lake south of the International Boundary had drained into Canada. As discussed previously under "Ground moraine" and "Ice-marginal outwash channels," an area east of the Souris River near the International Boundary is interpreted not to have been covered by glacial Lake Souris even though its surface is lower than the maximum height of the lake. Ice appears to have covered the surface until after the lake level was lowered to an altitude lower than the ground surface of the area.

The absence of any definable beach strands or wavecut cliffs along the west shoreline of the lake is somewhat puzzling. However, the water in the lake was doubtless very shallow for several miles out from the shoreline, as indicated by the almost imperceptible merging of the shoreline with the ground-moraine plain. Because of these conditions, the waves in the lake probably washed a broad belt of shoreline and the shoreline deposits spread out over a wide area. A lowering of the lake level, even a few feet, would have caused the waves to break many miles from the highest shoreline. If the lake level lowered gradually, which is probable, a more or less continuous beach of fine gravel and sand would be deposited closest to shore. Farther from shore, sand would be deposited over many miles of the lake floor. 'Where the lake was deeper and the mouths of the glacial outwash channels were farther away, as in areas north and northwest of Bantry, silt would be the chief material deposited.

Some material was deposited directly from the ice sheet into the ice-marginal lake. Most of this material appears to have been deposited at or near the ice front as kames, such as those near Buffalo Lodge Lake, or as irregular-shaped deposits mapped as glaciofluvial deposits undifferentiated as to origin. Inasmuch as both types of deposits are distinct landforms and their crests extended above the surface of the lake waters, they have been mapped separately from the lake deposits.

The much greater thickness of deposits in the southern half of the lake area, as compared with those in the northern half, is due not only to the longer existence of this part of the lake, but also to the larger sources of material for the southern half. When the northern half finally was freed of ice and the northern outlet to the lake came into existence, the lake probably drained rapidly. There was little time then for sediments to accumulate in the northern part of the lake.

\section{ENGINEERING GEOLOGY}

Extensive studies of the ground-water surface throughout the entire lake area have been made by the Water Resources Division of the U.S. Geological Survey and by the U.S. Bureau of Reclamation. Permeability is high in the sand and gravel and is moderate to low in the silt and silty clay. Possible leakage from proposed canals dug across these deposits should receive special consideration. The ground-water surface is within 6 feet of the surface in many places along the west shoreline.

Porosity is generally high, largely because the material is remarkably well sorted.

Foundation strength in the gravel and sand is high to moderate, and it can probably be increased, especially in the sand fraction, by compaction. The general angularity of the sand grains makes this material superior in foundation strength to better rounded sand grains of beach sands elsewhere. The sand is not sufficiently cohesive to be used for road fill without a surface binder. Till has been used advantageously for such a binder. Roads built of sand are also subject to excessive wind erosion. The fine gravel generally makes a good road fill, as does the silt and silty clay. The silt and silty clay, however, have low to moderate plasticity and rut bady when wet. Highway cuts and other slopes of more than 10 feet in the fine gravel and sand are prone to slump and are easily eroded. Slopes in the silt and silty clay are fairly stable even where nearly vertical.

Very little material is known to react in a deleterious manner, either physically or chemically, when used to make cement. Small chips of lignite, however, are relatively abundant in the sand fraction. The finegravel fraction contains minor amounts of biotite-rich granitic rocks that are subject to mechanical disintegration.

\section{RECENT DEPOSITS}

Landslide deposits, dune sand, and alluvium are described under the above heading. Deposition of all three probably started at about the time the last ice sheet melted from the area and has continued to the present. Therefore, the earlier deposits of each are probably of Pleistocene age; but inasmuch as the 


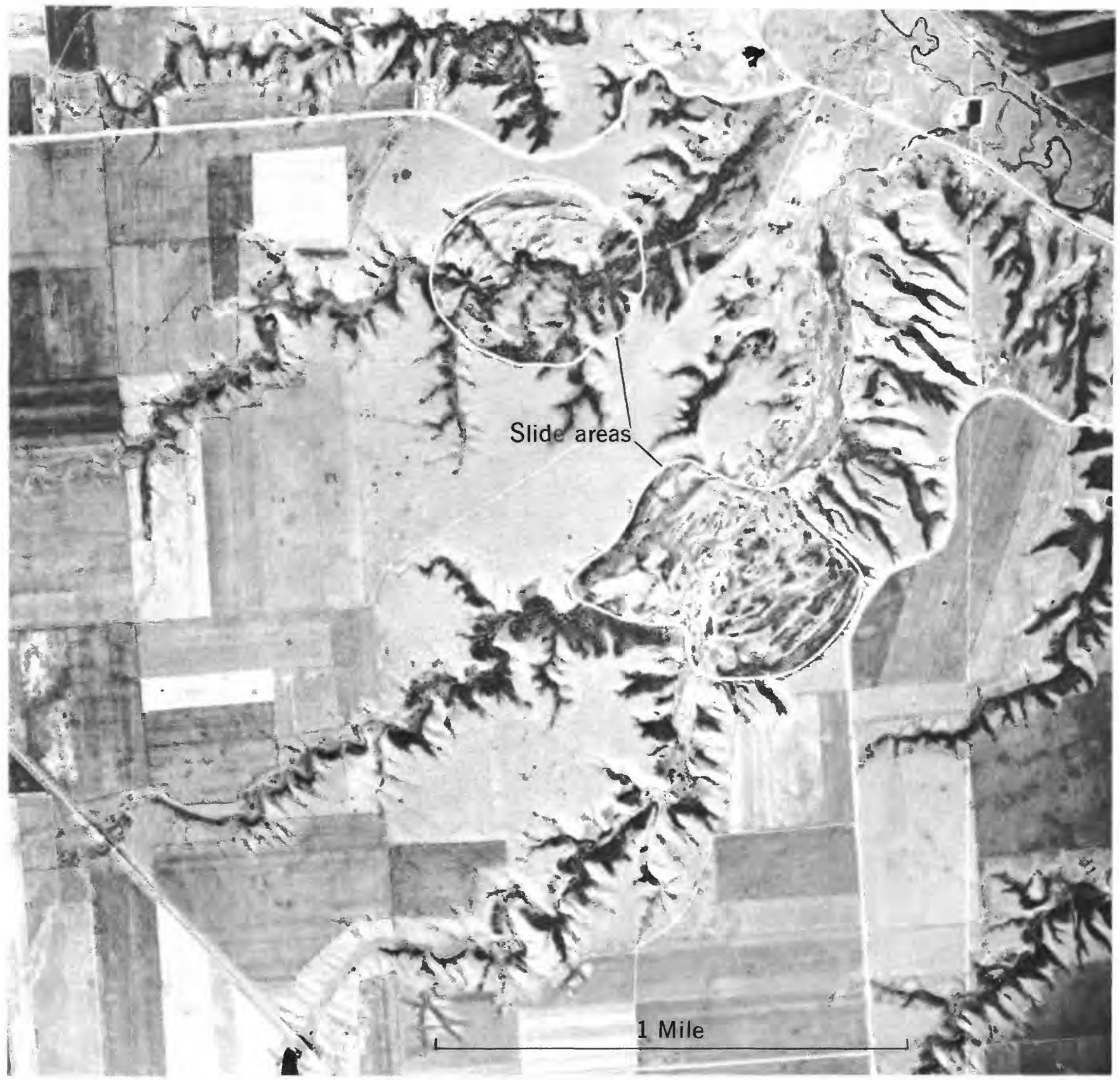

VIEW OF TWO LANDSLIDE AREAS ALONG VALLEY WALLS OF TRIBUTARIES OF THE DES LACS RIVER, N. DAK., IN SECS. 16 AND 21, T. 158 N., R. 78 W. 


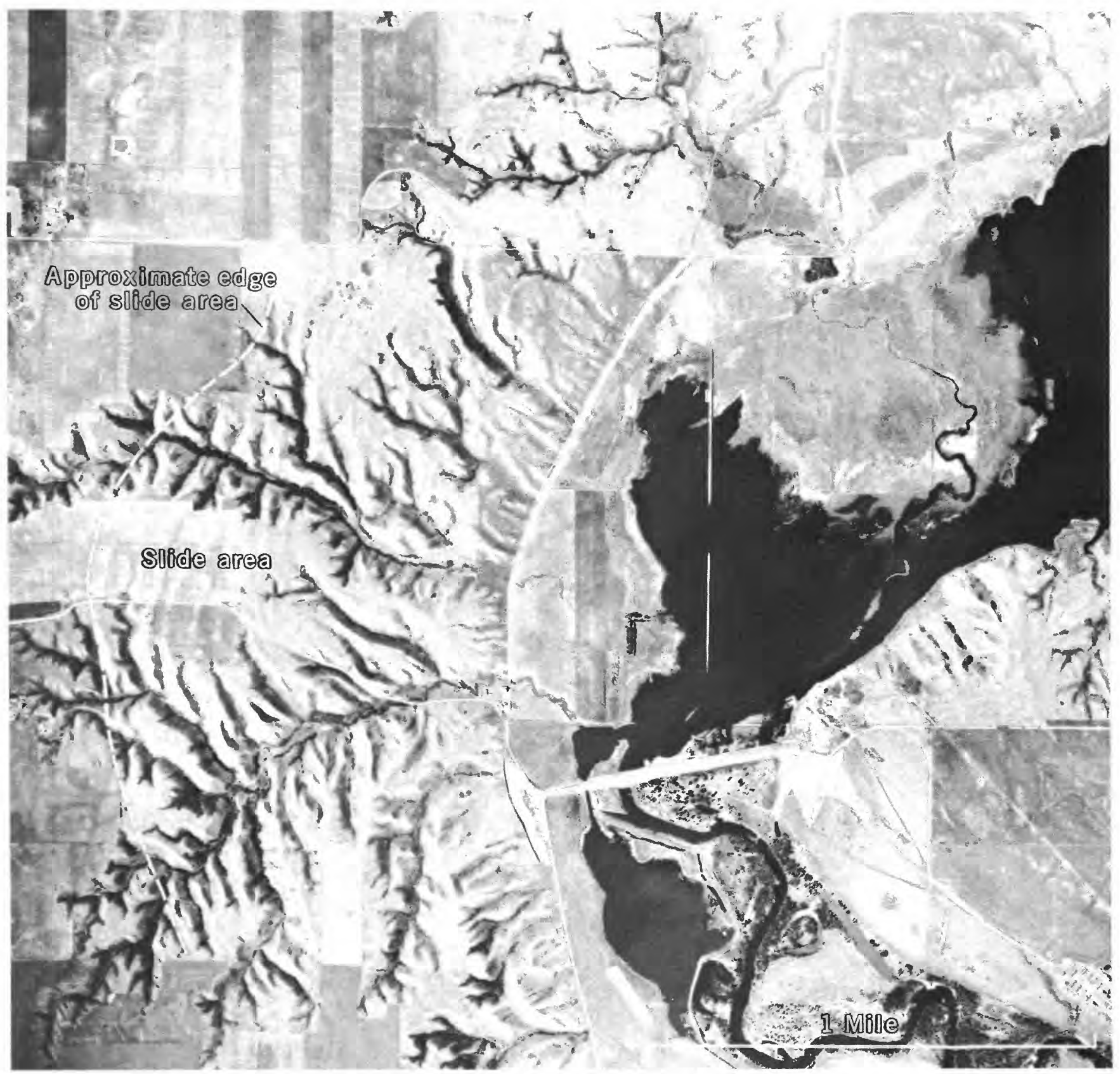


greater bulk of each unit is postglacial, they are described under "Recent deposits."

\section{LANDSLIDE DEPOSITS}

NAME, LOCATION, AND AREAL EXTENT

Large landslides are conspicuous along the valley walls and tributary coulees of the upper segment of the Des Lacs River and along the valley walls of the upper reaches of the Souris River. Slides in both areas differ in landform, general type, and probable origin. Material mapped as landslide deposits along the valley walls of the upper reaches of the Souris River is anomalous in form and probable origin. By strict interpretation, it should perhaps be excluded from this unit but, inasmuch as it is characterized by extensive slumping, it is included for convenience.

Landslides are present locally outside the two general areas denoted above; most of them, although of small extent, are shown on the map.

Slide areas range in size from individual slump blocks a few feet in maximum dimension to areas several miles long and more than a mile wide completely covered by slides. The largest area is along the upper reaches of the Souris River. Areas along the tributary coulees and valley walls of the Des Lacs River are commonly about a mile long and one-third to one-half mile wide.

\section{TOPOGRAPHY}

Along the Des Lacs River north of Kenmare, the slides are small and are confined almost entirely to the valley walls. Southeast of Kenmare, where the valley of the Des Lacs River is 150-200 feet below the upland, the more spectacular slides occur. Slides are especially large near the mouth of the larger tributaries on the southwest side of the valley in the vicinity of Donnybrook; long parallel blocks have broken away from formerly steep tributary wall slopes and have rotated to produce a series of successively lower ridges parallel to the tributary wall. Four or more ridges are common on each side of a tributary. The height of the ridges, from crest to upper intervening trough, is about 15 to 25 feet. A few bare scars are visible; more commonly, the slide areas are covered with grass. Small intermittent ponds, surrounded by brush and trees, are abundant on the back slope of individual slide blocks. Springs are common also in these places as well as farther downslope. Where there has been only a small amount of rotation of the blocks relative to the downslope movement, long, comparatively level strips are parallel to the walls and drop in successive steps toward the valley bottom. Nearer the bottoms of the tributaries, broken and jumbled blocks produce hummocky topography.
The major slide areas along the Des Lac River extend back from the mouths of the tributaries for only a mile or two and then, commonly, end abruptly along fairly well defined southeast-trending lines. The sides parallel to the tributary walls are slightly to moderately arcuate (see pl. 11).

The second type of landslide is conspicuous along the Souris River valley upstream from its confluence with the Des Lacs River. This type forms arcuate bands of low arcuate parallel ridges and undrained depressions on the upslope sides of the ridges (see pl. 12). The crests of the ridges are rarely more than 30 feet high and, in most places, are nearer 15 feet. Recent tributaries have eroded $\mathbf{V}$-shaped channels across the ridges. Secondary branches of the tributaries, however, are controlled by the intervening troughs and, hence, trend parallel to the ridges.

\section{THICKNESS}

The thickness of landslide deposits in the Des Lacs River area depends on the depths to which the arcuate slip surfaces extend (fig. 13), which, in turn, depend largely upon the depth of the valley in which the sliding occurs. Hence, individual slide blocks may be several tens of feet thick, in some places, perhaps more than 100 feet thick.

Little information is available on thicknesses of the second type of landslide deposit. Undercut banks along the shore of Lake Darling show that material at least 20 feet thick has slumped. Thicknesses of $30-50$ feet could, perhaps, be expected in some parts of the deposits.

\section{STRATIGRAPHIC POSITION AND AGE}

Thin accumulations of slopewash and colluvium locally overlie landslides.

Few slides in the Des Lacs River area exhibit fresh scars, which shows that in most places sliding is not now very active. The presence of vertical trees, several inches in diameter, along the back slopes of the rotated blocks shows that little sliding has taken place during the last 20 years or more. But some slow movement is still taking place, as is indicated by the fact

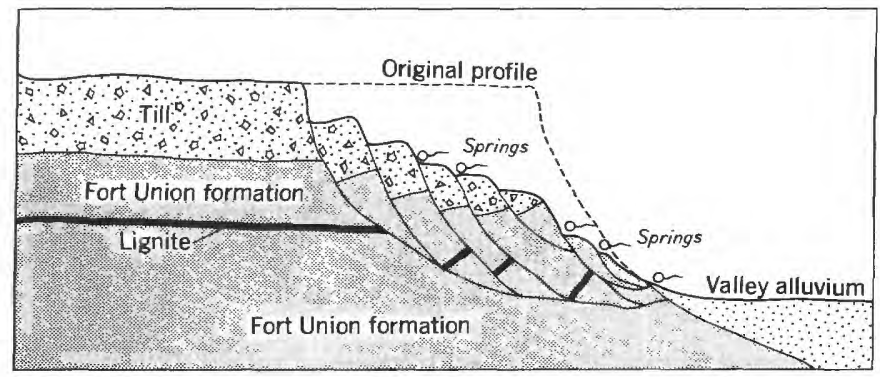

Figure 13.-Diagrammatic cross section of a typical landslide in the Des Lacs River area. 
that lignite mines which have been dug in the slide areas have to be retimbered constantly because of movement of the walls.

There is little or no evidence that sliding is still taking place in the upper reaches of the Souris River valley. The fact that river-terrace deposits truncate and overlie the landslide deposits shows that most or all of the material slid before deposition of these terraces. Inasmuch as the slides are probably all in Mankato till, their age is restricted to the short interval between the deposition of the till and the deposition of the terraces by melt waters of the Mankato ice sheet.

\section{GRAIN BIZE, SHAPE, AND IITHOLOGIC COMPOSITION}

In slide areas in the valley of the Des Lacs River and its tributaries, both ground moraine and underlying beds of the Fort Union formation have failed. In most places, probably more material of the Fort Union formation than till is involved. However, bedrock is exposed only in a few places in the slide blocks. Two lignite beds, 2-4 feet thick, in the Fort Union formation are fairly strong aquifers; in them most springs in the slide areas have their sources.

Bedrock is not known to be affected in sliding in the Souris River valley area. Till, intercalated with stratified sand, fine gravel, and smaller amounts of silt, constitutes the slide masses. Till is probably the predominant material affected and constitutes most of the surface material. Stratified material consists predominantly of well-bedded and well-sorted beds of sand and silt. However, lenses of sand or silt less than 100 feet long are common. Beds are commonly tilted and sheared and some are folded. As shown in figure 14, vertical shear planes offset individual beds 6 inches to a foot in a series of steps. Beds are tilted from a few degrees to vertical. Several exposures show folded to highly contorted beds (see fig. 15). Several exposures along the east shore of Lake Darling show soil or humus-rich layers intercalated in the landslide deposits. Most of these layers are tilted at high to vertical angles. At one locality, wave action of Lake Darling has stripped off all the shoreline debris and exposed a very

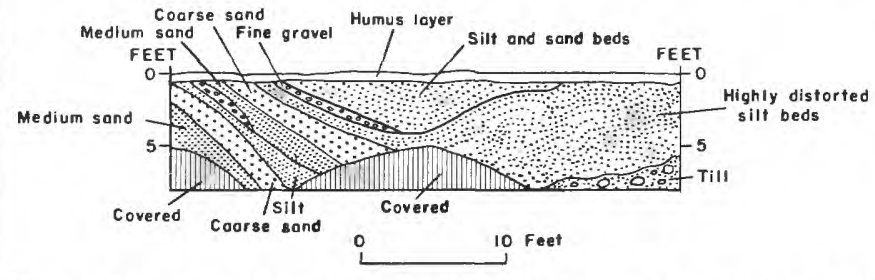

FrgUkE 15.-Generalized cross section showing distorted beds in the NW $1 / 4$ sec. 32, T. 158 N., R. 84 W.

black humus-rich layer, about 4 inches thick and several feet long, which stands vertically with till on both sides.

TYPE AND ORIGIN OF DEPOSITS

The slides are all of the slump type. Movement has been slow and the material involved has not been greatly deformed.

Slides along the Des Lacs River have been formed by long parallel slightly arcuate blocks of till-covered bedrock breaking away in successive steps from steep valley walls. When these blocks moved downslope, they rotated so that their back sides sloped into the hill and their outer edges were tilted upward to form a series of successively lower ridges approximately parallel to the valley ways. Other than tilting and shearing, there has been little rearrangement of the Fort Union beds. Some beds near the bottoms of tributaries are tilted to vertical and locally may be overturned. Many slide blocks near the bottom have been broken into smaller blocks by later movement upslope. Sliding extended upstream only to a point where the Fort Union beds along the valley wall exceeded their critical point of stability. The tributary valleys have fairly steep gradients and, hence, toward the heads of the tributaries only till forms the valley walls. This probably accounts for the abrupt upstream termination of sliding.

Presumably sliding is facilitated by a large amount of ground water that percolates through the lignite and other permeable beds of this formation. The slides are localized on the west side of the Des Lacs River valley; the water issuing from the springs in the slide areas probably has its source in the numerous

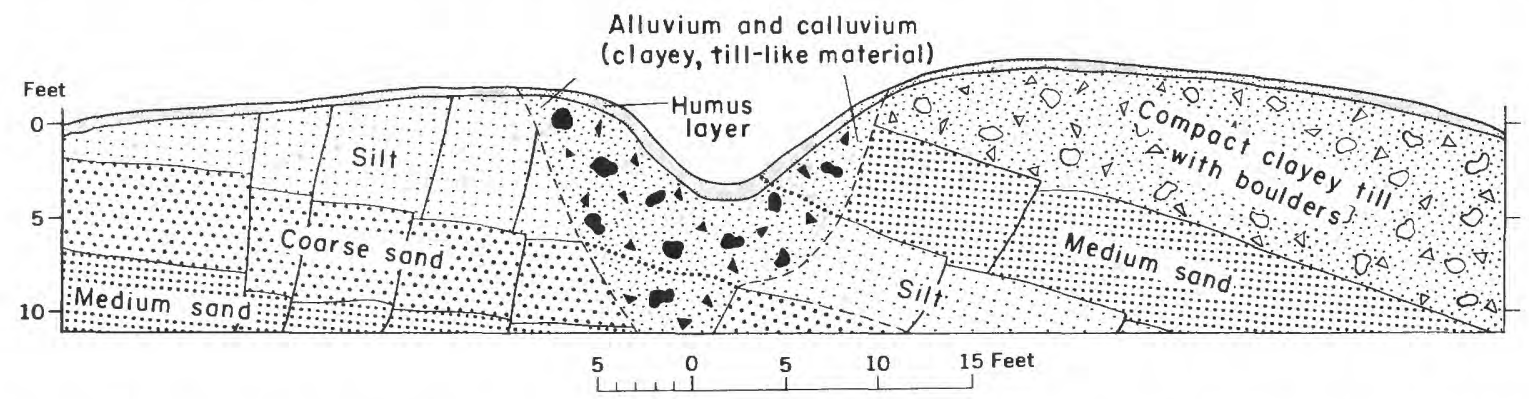

Figtre 14.-Generalized cross section showing tilted and distorted beds in the SW $1 / 4$ sec. $32, \mathrm{~T}$. $158 \mathrm{~N}$., R. 84 W., N. Dak. 

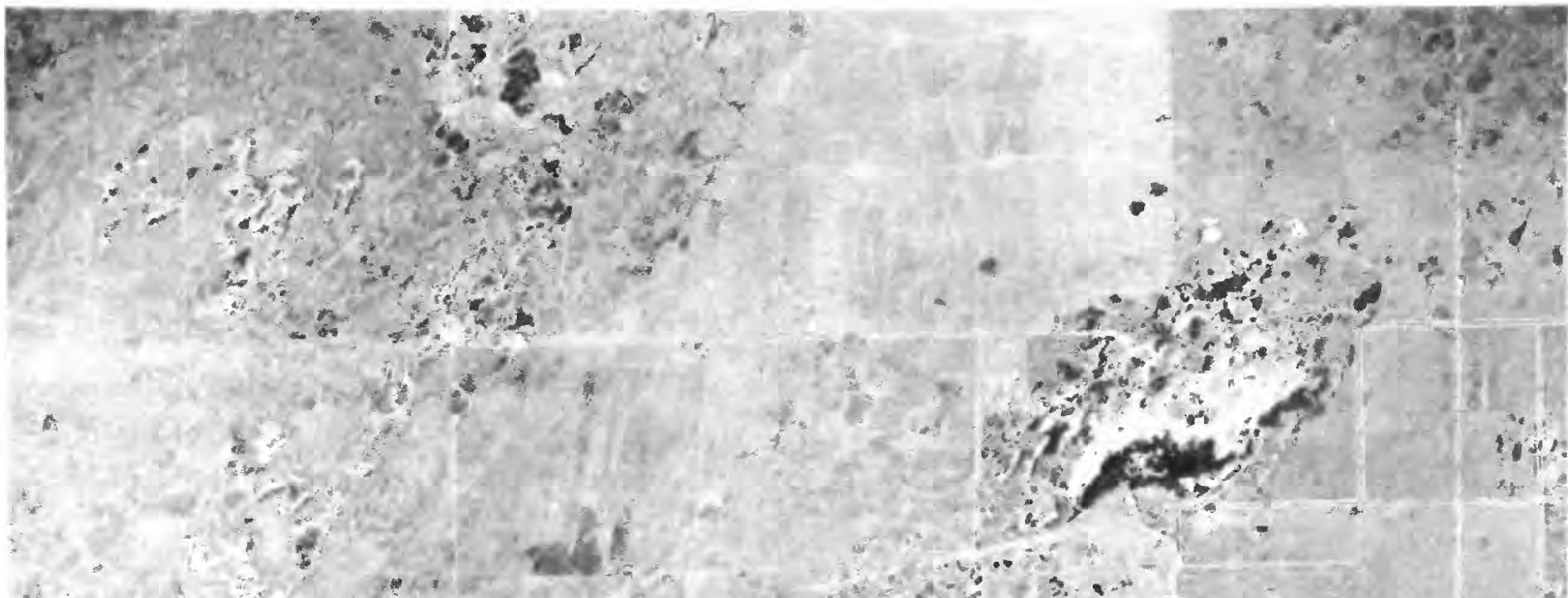

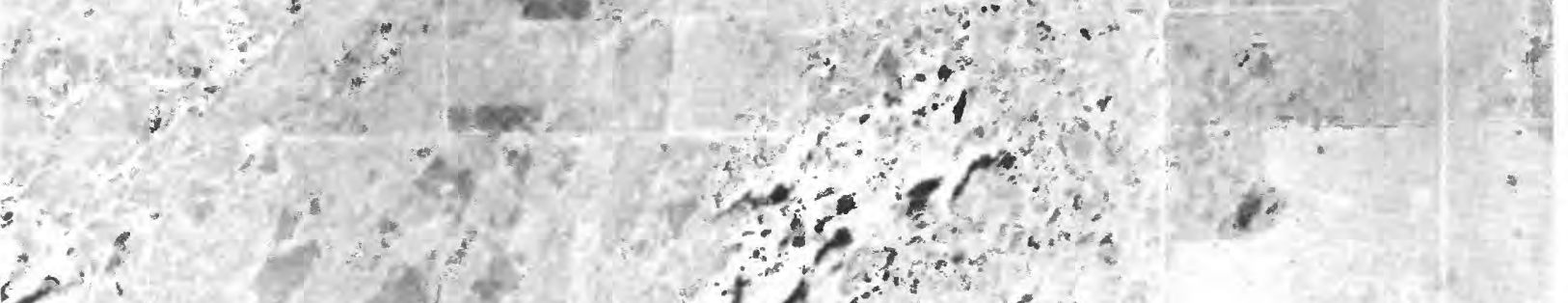

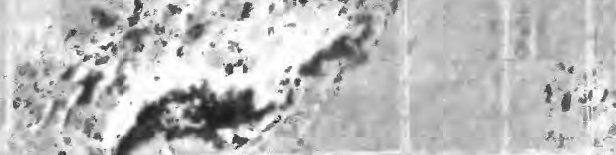

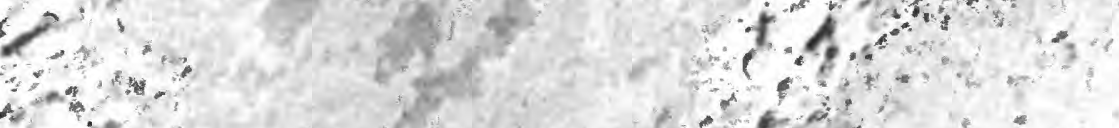

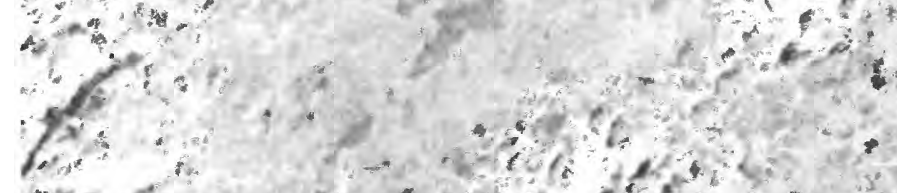

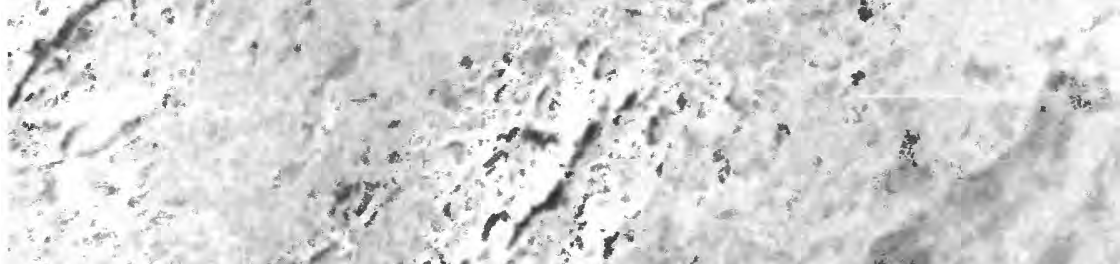

(1)

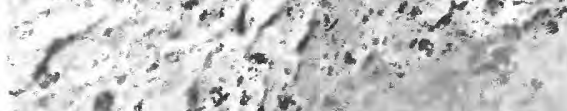

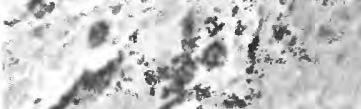

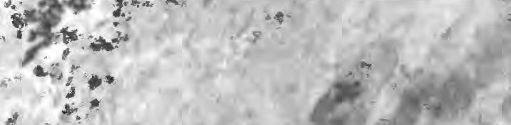

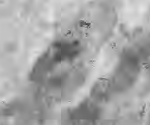

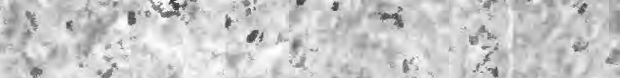

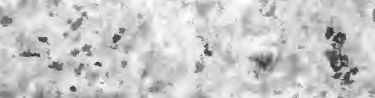

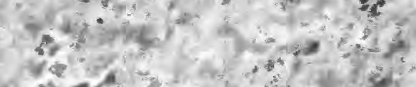

$6-2, \quad 40.80,35$

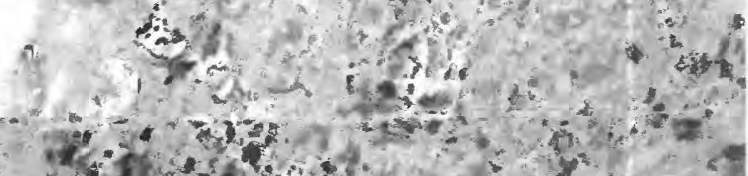

公

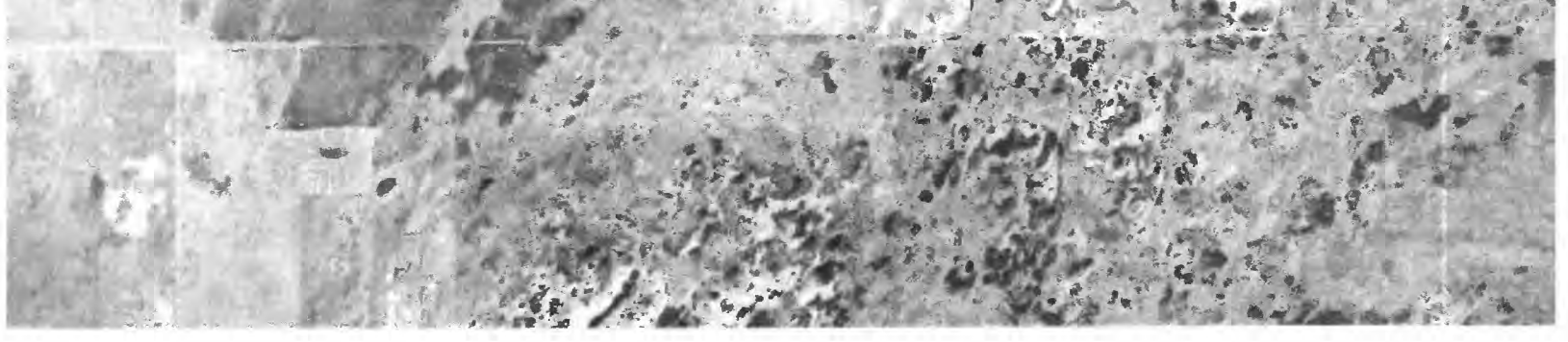


ponds and lakes on the Max moraine, a few miles to the southwest. During deglaciation, this source of water was probably much greater than at present, inasmuch as there probably were still numerous blocks of melting ice, wholly or partly buried in the Max moraine.

The type and origin of slides along the valley of the Souris River is less clear than for slides along the Des Lacs River. The distribution and crescentic outline of each slide tract suggests that sliding was localized in bends or meanders of a pre-Mankato Souris River valley in places where till and stratified material were deposited against the valley walls during the last ice advance. Ice might have occupied most of the intervening part of the valley and supported the Mankato till against pre-Mankato till walls. When the ice started melting from the valley, the Mankato till and stratified deposits, which had lower stability than the pre-Mankato till-perhaps in part because of a higher water content-slid toward the center of the valley. Sliding continued until most of the ice, if not all, had melted from the valley, but it must have stopped before the main ice front had retreated very far, because riverterrace deposits truncate the lower parts of the landslides but do not themselves show evidence of movement since deposition.

There are a few relatively small landslides along the south wall of the Souris River valley, in the eastern part of Ward County in the vicinity of Sawyer. Although only till is exposed at the surface, Fort Inion strata probably are involved in the sliding also. The slides are chiefly of the slump type, in which successive blocks of material have rotated so that their top sides dip into the hill and their outer edges tilt correspondingly upward to produce a series of ridges roughly parallel to the valley wall.

\section{ENGINEERING GEOLOGY}

Most of the landslides consist of large discrete masses that have many of the same engineering geology characteristics as the materials from which they are composed. In some respects, the characteristics of the deposits are different from similar materials that haven't moved. The landslides in the Des Lacs River area consist of till and Fort. Tnion strata and exhibit many of the characteristics of these two units. The landslide deposits along the Souris River are composed of till and stratified drift, and many of their characteristics are similar or identical to those of like deposits elsewhere.

The fact that the deposits have slid since deposition gives them certain characteristics which they formerly lacked. Even though the slides are wholly or partly stabilized at present, small factors which formerly ex- isted, or new ones, could upset the equilibrium. Downcutting of the Des Lacs River valley and headward erosion and deepening of its tributaries would probably reactivate some essentially stabilized slides and cause new ones to form. An increase in precipitation, which would result in more ground water in the Fort Tnion formation, might cause additional sliding. In the Souris River area, deepening of the valley might reactivate the old slides but probably would not cause many new ones, because much of the area underlain by the unstable stratified drift has probably already slid. The compact older till walls, back of the more recent till mixed with stratified material, are presumed to be relatively stable. Increased precipitation probably would cause little additional sliding in this area, because permeable Fort Union strata are not involved in the sliding and the nearly impervious till walls back of the slide area allow little or no ground water to enter the area.

Slides can be reactivated by man. Cutting away the toe of a slide during highway, canal, or other construction is an effective method of reactivating the slide.

Allowing additional surface water to enter landslide areas, by removal of water-retaining soil and vegetation upslope, contributes to further movement. The water collects in the troughs between the ridges, and it seeps down along the slip surfaces of the blocks. By lubricating the slip surface and increasing the pore pressure and weight, water helps reactivate the slide. Adding weight to the landslide mass by building a high fill for a highway, or by constructing a large building on the landslide mass, may upset the established equilibrium. Vibrations caused by large trucks or other vehicles operating on a highway built on a slide area may further facilitate movement. It is obvious that large landslide masses should be avoided, whenever possible, in construction of most kinds.

\section{DUNE SAND}

\section{NAME, LOCATION, AND AREAL EXTENT}

Groups of sand dumes have been deposited in the southern part of the bed of glacial Lake Souris. Dunes are conspicuous south of Denbigh and, locally, on both sides of the Souris River between ITpham and Towner.

Individual dune groups range in areal extent from small patches, a few hundred yards long, to large tracts, several miles long and 1-2 miles wide. Most dunes less than 5 feet high are not shown on the map because of the difficulty of distinguishing them from adjacent lake deposits of nearly identical composition. Each dune group commonly consists of closely spaced or partly coalesced individual dunes (see pl. 13). 


\section{SIZE AND FORM}

Individual dunes consist of ridges less than a quarter of a mile long, whose crestlines usually trend northwest. A dune group consists of several parallel to subparallel ridges which in aggregate also generally trend northwest. In most dune groups, the ridges are so closely spaced that they coalesce, and comparatively shallow troughs separate ridge crests. In some places, however, ridges are far enough apart so that the intervening troughs extend to the level of the surrounding glacial lake deposits. The ridges range in height from barely perceptible rises to features as much as 50 feet high. Most are 15-30 feet high and are asymmetrical. The crests are sharp and uneven. The windward, or southwest, slope of a ridge is gentle, whereas the lee slope is between 30 and 40 degrees. Sand blows up the gentle slope, is deposited just over the crest, and slides down the lee slope. Fairly heavy growths of shrubs and small trees on many of the lee slopes are being slowly covered, but they help maintain a steeper slope than would be possible otherwise. Most of the windward slopes are grass covered, except for fairly numerous roughly crescentic blowout areas where the wind is actively removing the sand. The blowout areas are commonly $20-50$ feet across and 5-10 feet deep and are concare toward the prevailing wind.

\section{STRATIGRAPHIC POSITION AND AGE}

The dunes rest on glacial lake deposits and merge almost imperceptibly with them. No younger deposits overlie the dunes except along the Souris River, where alluvium locally overlies or interfingers with the dune sand.

The dunes probably began to form soon after glacial Lake Souris was drained. At present, most of the dunes are fairly stable, but they are migrating very slowly northeastward; trees on the leeward sides attain diameters of several inches before being covered by sand. Blowout areas in the adjacent glacial lake deposits are mostly grass covered. A few dune areas are conspicuously active; one such area is on the east shoreline of Buffalo Lodge Lake. This area contains a few roughly circular dunes as much as 25 feet high and a few hundred yards in diameter. The sand appears to be derived from the east beach of the lake.

Some of the dune groups between ITpham and Towner, west of the Souris River, are more active than most groups elsewhere. Not only are many of their windward slopes fairly bare of regetation, but most of the blowout areas in the adjacent lake deposits are active. One small group, 4 miles north of Towner, is migrating into the channel of the Souris River and probably will divert the river to the east.
During the dry years of the early thirties the dunes and blowout areas were much more active than they were when they were being mapped. Aerial photos taken of the area during those years show many dunes and blowout areas devoid of all vegetation, except on the leeward slopes of the dune ridges.

\section{GRAIN SIZE, SHAPE, AND IITHOLOGIC COMPOSITION}

The dunes consist almost wholly of sand of almost identical range in grain size as that of the sand that composes the adjacent deposits of glacial Lake Souris (see fig. 12). For this reason the characteristic constructional topography of the dunes is the basis for separating the two deposits.

Most of the sand grains are sharply angular, unpitted, and remarkably similar in shape, size, and surface appearance to those of the adjacent glacial lake deposits. A few are subrounded and frosted.

The sand grains of the dumes are mostly quartz. Lignite and shale chips, which are present in the adjacent lake deposits, are almost absent. A sample taken from the crest of a dune 4 miles southwest of Denbigh, in the SW1/4 sec. 36, T. 156 N., R. 77 W., contained 1.68 percent of minerals that have a specific gravity greater than 2.8. This compares with a sample of glacial lake deposits, obtained 1 mile to the north, that contains 2.54 percent of minerals that have a specific gravity greater than 2.8. In both places, the heavy minerals consist chiefly of magnetite, ilmenite(?), garnet, and hornblende.

\section{BEDDING AND SORTING}

Eolian crossbedding is well developed in some dunes. Prominent foreset beds on the northeast or lee slopes of the dunes dip as much as $30^{\circ}$. A few humus-rich zones 1-2 inches thick interlayered in the dunes appear to be very immature soils covered by the slowly migrating sand. The material is very well sorted.

\section{WEATHERING}

The over-all color of the dume sand is brown, evidently owing to oxidation of minerals that contain iron, although little oxidation of individual mineral grains is evident. Some of the black minerals, garnet grains. and feldspar grains are pitted.

\section{ORIGIN AND TYPE OF DEPOSITS}

The dunes appear to be derived wholly from the glacial lake deposits, but only from glacial lake deposits that consist of sand of about the same grain size. No dunes are present near the west shoreline of the lake area, presumably because most of the material there is too coarse and the winds from the west do not 
have a broad enough sweep of the lake bed to pick up any deposits, even if they were fine enough. Dunes are absent in the northern parts of the lake area because the lake deposits there are chiefly cohesive silts and silty clays.

\section{ENGINEERING GEOLOGY}

Permeability is high throughout the deposits. Although there are some depressions without surface drainage bet ween dune ridges, subsurface drainage prevents ponds or lakes from forming.

Foundation strength, for other than small structures, is poor owing to the general steepness of the slopes and lack of cohesion of the sand. Highway and other cuts are subject to excessive slumping, gullying, and wind erosion. Road fills built of dune sand are very unstable because of low cohesion of the material and are also subject to considerable wind erosion. A more cohesive surface binder, such as till, is necessary for the construction of suitable roads.

Little or no material that would react deleteriously in cement, either physicaly or chemically, is in the deposits.

\section{ALLUVIUM}

NAME, LOCATION, AND AREAL EXTENT

The alluvium consists of clay, silt, sand, and fine gravel deposited chiefly by postglacial streams and their tributaries. Nearly all of the mapped deposits underlie the valley floors of the Souris and Des Lacs Rivers and their larger tributaries. Narrow strips of alluvium along minor tributaries were not differentiated from the adjacent geologic units; also, deposits of alluvium and colluvium, deposited by slope wash and soil creep along the valley walls, were not differentiated from the underlying unit, which is generally till. On the other hand, the larger alluvial and colluvial fans at the mouths of side tributaries were mapped as alluvium. Thin alluvial deposits that were formed by small, intermittent postglacial streams in the floors of outwash channels have not been mapped separately. Likewise, thin deposits of clay and silt in undrained depressions on the ground moraine and Max moraine have not been differentiated from adjacent deposits.

Alluvium extends the full length of the valleys of the Souris River and Des Lacs River in a strip onefourth to slightly more than 1 mile across. It extends less than 10 miles up most of the larger tributaries and commonly less than 5 miles. Along a few tributaries, strips of alluvium are locally 1 mile wide or more but in most places are considerably less than one-fourth mile.

TOPOGRAPHY

Most alluvial deposits in the river valleys have moderately flat surfaces that are modified locally by many abandoned meanders partly filled with more recent alluvium. Upstream from Velva, the gradients of the alluvial floors of tributaries of the Souris and Des Lacs Rivers are considerable. Downstream from Velva the gradients of the tributary streams decrease and the alluvium forms a nearly flat surface.

Fans of alluvium and colluvium extend part way across the river-valley floors, and, in a few places, as along the upper reaches of the Des Lacs River valley, they dam the main stream and form lakes. In most places, the outer limits of the fans are moderately well defined by a break in slope, but in other places, they merge imperceptibly with the valley-bottom alluvium and form gently convex profiles in the valley bottom.

\section{THICKNESS}

It is difficult to determine thicknesses of alluvium because of the lack of natural exposures and because of the difficulty of distinguishing alluvium, during drilling, from underlying glacial outwash deposits. Most natural exposures are along undercut banks of the rivers and are rarely more than 20 feet high.

In 1946 the Bureau of Reclamation drilled 5 churndrill holes across the Des Lacs River valley, 11/2 miles northwest of Kenmare. (See fig. 16.) Holes 1 and 5 penetrated only till and bedrock. Hole 2 penetrated 12 feet of artificial fill, then 50 feet of inter-

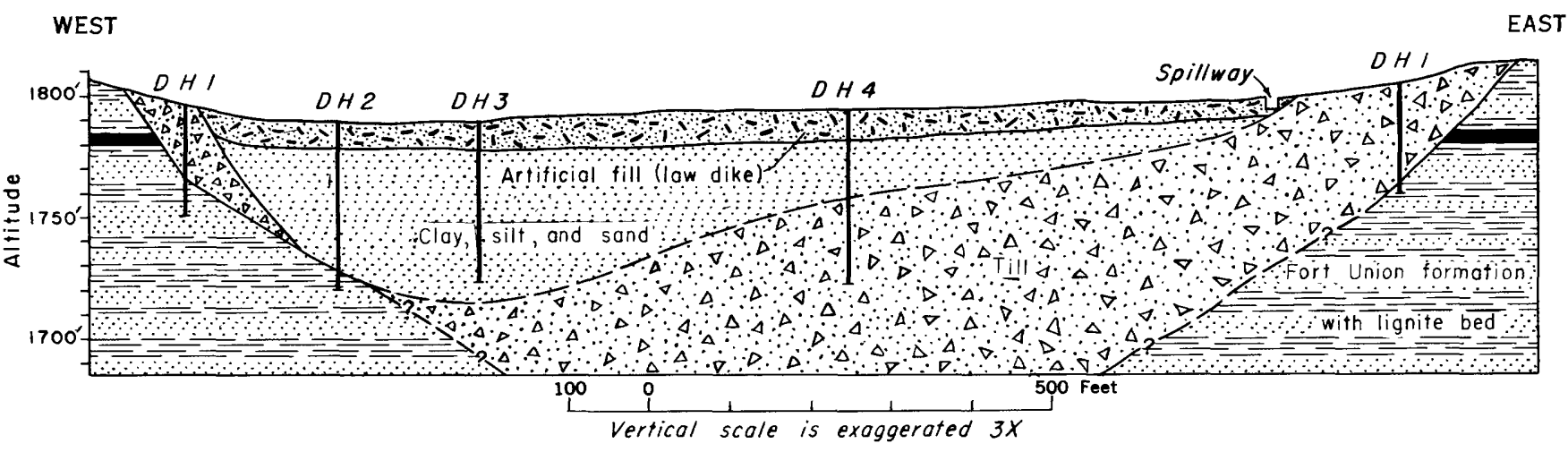

Figure 16.-Cross section of the valley of the Des Lacs River, $1 \frac{112}{2}$ miles northwest of Kenmare, N. Dak. 
bedded clay, silt, and sand, and stopped in 8 feet of Fort Union formation. Hole 3 penetrated 12 feet of artificial fill and 54.5 feet of clay, silt, and sand, similar to that in Hole 2. Hole 4 was drilled through 12 feet of artificial fill, $2+$ feet of clay, silt, and sand, and 35.5 feet of till. It is difficult to tell whether or not the entire section of interbedded clay, silt, and sand in drill holes 2,3 , and 4 consists entirely of postglacial alluvium or whether the lower part is glacial outwash. In most other places, the glacial out wash is considerably coarser than this material, hence there is reason to believe that the clay, silt, and sand is all alluvium. About 20 miles upstream, in the NE $1 / 4$ sec. 34 , T. 164 N., R. 89 W., bedrock reportedly was penetrated in constructing some of the bridge footings across the lake. The depth to bedrock is not known exactly but alluvium is probably less than 30 feet thick and may be considerably thinner in this part of the valley.

In the J. H. Kline well 1, which was drilled for oil in the valley bottom of the Des Lacs River, 31/2 miles southeast of Carpio, 95 feet of fine to medium sand was penetrated before bedrock was reached. The lower part of the sand section may be fine glacial outwash, but nearby outwash-terrace deposits are much coarser grained than any of the material in the 95-foot section.

In a hole drilled in the bottom of the upper reaches of the Souris River valley, in the SW1/4 sec. 28, T. 162 N., R. 86 W., 71 feet of surficial deposits was penetrated before bedrock was reached. As indicated by the grain size, the lower part of the surficial deposits is probably glacial outwash, but the contact hetween outwash and the overlying alluvium has not been determined. Possibly the upper $35-45$ feet is alluvium.

A large number of wells and test holes (Akin, 1947, p. 1-99) were drilled for water in the valley fill near Minot. Known depths to bedrock in the holes ranged from 92 feet to 248 feet, and, in some places nearby, bedrock may lie even deeper. Elsewhere in the Souris River valley, near Minot, the fill ranges in thickness from 50 feet to about 200 feet, but it is difficult to determine what part of this thickness is Recent alluvium. In many wells, however, glacial outwash and till constitute the entire section, except for a relatively thin veneer of alluvium. Probably the average thickness of alluvium is 30 feet.

In a hole drilled near the middle of the valley at Sawyer, in the NW1/4 sec. 11, T. 153 N., R. 81 W., the drill penetrated 165 feet of valley fill before hitting bedrock (see $\log$ of hole). This fill appears to consist entirely of alluvium and glacial outwash. It differ's from material penetrated farther up the valley in haring near the base one or more dark humified soil layers such as characterize the upper 10-15 feet of Recent alluvium along the valley floors.

Log of hole drilled in valley fill at sawyer, in the $N \mathrm{~W}^{1 / 4}$ rec. 11 T. 15.3 N., R. 81 Wr.

Material

Thickness (feet)

Alluvium (lower part may be glacial outwash):

Clay, sandy, brown

Sand and clay beds

Sand and fine gravel; small bivalve shell fragments; lignite chips as much as three-fourths inch in diameter: sandy clay near bottom

Clay, gray, pebble-free, very homogeneous

Sand mixed with silt and clay: lignite chips onehalf inch in diameter

Clay, silty, pebble-free, thinly laminated; nearly black in color except for small white blebs (caliche): may be a humified zone

Clay, silty : interlayered with coarse gravel: lignite and wood chips as much as one-third inch in diameter.

Boulder, limestone

Clay, silty and sandy, gray: a few pebbles

Clay, silty and sandy, slark gray: (containing darker layers which may be humidified zones_.........-

Fort Union formation :

Siltstone and unconsolidated sandstone

(Hole continued to depth of 297 feet but no additional description is given here)

Little is known about the thickness of allurium along the east loop of the Souris River. In most places, about 20 feet of sand appears to orerlie till. However, it is difficult to distinguish the sand deposited by the rixer as allurium from the sand of deposits of glacial Lake Souris. One hole drilled in the Souria River valley fill, $11 / 4$ miles south of the International Boundary, in sec. 31, T. 164 N., R. 79 E., penetrated 48 feet of fill overlying bedrock.

Alluvium along tributary streams is generally less than 15 feet thick; where the streams have moderately steep gradients, as in the long coulees that enter the Souris River and Des Lacs River valleys, it is commonly less than 5 feet. Where tributary streams enter the valleys the valleyward sides of alluvial fans are considerably thicker than their heads. The surfaces of the fans are commonly $5-15$ feet above the river-deposited alluvium.

\section{STRATIGRAPHIC POSITION AND AGE}

Alluvium is nowhere overlain by other deposits, except along the east loop of the Souris River where a few small sand dumes are encroaching upon river alluvium. River alluvium is underlain by outwash sands and gravel, till, deposits of glacial Lake Souris, and possibly, in a few places, bedrock. Tributary alluvium is generally underlain by ground moraine. 
Contacts between alluvium and till and between alluvium and bedrock are sharp and distinct. Contacts between alluvium and outwash are commonly indistinct and gradational because of similarity in the lithology of the deposits and because both were deposited by streams. Generally, alluvium is finer grained than outwash; most material coarser than fine gravel is outwash. Contacts along the east loop of the Souris River between alluvium and underlying deposits of glacial Lake Souris are almost impossible to distinguish because both deposits are sand of almost identical lithologic composition. The contacts are arbitrarily placed at breaks in slope that mark very low valley walls-a placement that is based upon the fact that the surface of the alluvium is commonly swampy or marshy. Vegetation growing in these areas forms a distinctive pattern on aerial photographs.

\section{GRAIN SIZE, SHAPE, AND LITHOIOGIC COMPOSITION}

Nearly all of the alluvium consists of clay, silt, sand, and fine gravel. Silt and sand sizes predominate. The tributary alluvium, where the stream gradient is steepest, consists mostly of sand but contains fine gravel and silt. The alluvium of the Des Laes River valley, where the surface has a considerably lower gradient than the tributary streams, consists chiefly of silt, sand, and minor amounts of clay. The allurium of the Souris River valley downstream to Verendrye consists mostly of clay, silt, and sand. It contains a greater proportion of material of clay size than does the alluvium of the Des Lacs River. Downstream from Verendrye the alluvium is derived almost entirely from deposits of glacial Lake Souris and consists chiefly of sand.

Because of the low gradients of the rivers and the generally small volumes of water in the water courses, there is little abrasion of material by fluvial action. Therefore, except for possibly slight rounding of the larger grains, most of the grains have essentially the same shape as before they were deposited as alluvium.

The lithologic composition of the alluvium reflects the deposits from which it has been derived. Most of the alluvium is derived from erosion of ground moraine; hence, it is similar lithologically to that part of the till of approximately equal grain size. Along the east loop of the Souris River, the alluvium is nearly identical to the sands of glacial Lake Souris.

Lignite chips are fairly common in some parts of the deposits. Generally, they are less than one-fourth inch long. Pieces of wood also have been reported in some of the drill holes dug in valley fill in the vicinity of Minot and Sawyer. They were reported at depths of to and 85 feet.

\section{BEDDING AND SORTING}

Most of the alluvium is moderately to well sorted. Individual beds are commonly one foot to several feet thick. Cross-bedding is conspicuous locally, especially in sand.

\section{INDURATION, CEMENTATION, AND WEATHERING}

Most of the deposits are neither indurated nor cemented. Caliche is far less abundant than in most of the other surficial deposits. Fluvial waters presumably have removed most of the free calcium carbonate. Ferruginous cement is almost totally lacking.

Most of the alluvium has been accumulating slowly since glacial melt waters drained from the area. As a result, it is partly weathered through a greater thickness than most other deposits. Several immature soil profiles are among the more conspicuous effects of weathering. The upper 10-15 feet of the alluvium commonly contains 5-8 dark humified bands, a few inches to more than 1 foot thick, that form immature A horizons. Each band is underlain by a brown immature B horizon and a gray immature C horizon. The $A$ and $B$ horizons are generally fully leached of calcium carbonate. The C horizon appears to contain less calcium carbonate than do similar horizons in till or outwash. As a result, caliche is less prominent. Whether or not humified zones are present at depths greater than 15 feet is not known, but drill data indicate that, at least in places, they may extend to the base of the alluvium.

Weathering is facilitated by desication cracks formed at the surface in dry weather. Such cracks are especially common in the more clayey material fractions where openings, $2-4$ inches wide, extend to depths of +6 feet.

\section{ORIGIN AND TYPE OF DEPOSIT}

Before melt-water drainage was ended by disappearance of the ice, the streams carried both melt water and nonglacial runoff' and there was an interningling of outwash and nonglacial alluvium. Thus, the contact between outwash and alluvium is gradational.

\section{ENGINEERING GEOLOGY}

Permeability is generally less in alluvium than in the other stratified surficial deposits. It is moderate to low in the silt and clay that underlies large segments of the Souris River valley. From Verendrye downstream, however, the alluvium is chiefly sand and the permeability is high. The alluvium in the valley of the Des Lacs River is generally coarser than in the val- 
ley of the Souris River above Verendrye and has higher permeability. The alluvium in the other tributaries and in alluvial fans at the mouths of the tributaries is generally coarser than that underlying the floors of the main valleys, and permeability is higher. However, in most deposits, clay is mixed with larger grains, so that the permeability is lower than one might expect from the percentage of grain sizes.

Much of the alluvium in the major valleys is poorly drained; hence, water is fairly close to the surface, and abandoned meander's along the Souris River valley are intermittently or perennially under water.

Most slopes have low to moderate stability. Cuts in silt and sand are subject to rapid gullying but are less erodible if they have some clay binder. Organic content is high in many poorly drained deposits. High organic content, plus rather uniform grain size in some of the fine deposits, cause compaction difficulties. The fine deposits generally have low foundation strength; heavy structures should be built on coarser material, if possible. Because of poor sorting, most deposits cannot be used as a source for sand and gravel.

\section{STRUCTURE OF UPPER CRETACEOUS AND TERTIARY ROCKS}

Knowledge of the structure of Upper Cretaceous and Tertiary rocks in the mapped area is based mostly on a study of the exposed bedrock in and adjacent to the mapped area. However, some problematical and indirect inferences of bedrock structure are based on a study of landforms of the surficial deposits.

Prior to 1946, strata in the Souris River area and vicinity were considered to be essentially horizontal. Ballard (1942, p. 1568) showed structure contours of the top of the Dakota sandstone that indicated, within the Souris River area, a gentle southwesterly dip of about 25 feet per mile toward the center of the Williston basin to the southwest.

Surface mapping in the Souris River area, although based on scanty data and therefore subject to revision, suggests that Ballard's concept of direction of dip may not hold for younger rocks in much of the mapped area. Instead the surface rocks may form a broad shallow northwest syncline locally modified by folding and faulting. This inference is based on (a) direct evidence of structure in the Souris River area, (b) direct evidence of structure in adjacent areas, and (c) problematical and indirect inference of structure within and adjacent to the mapped area. However, because of unconformities and for other reasons, it is unlikely that this surface structure reflects structure at depth.

\section{DIRECT EVIDENCE OF STRUCTURE IN SOURIS RIVER AREA}

\section{STRUCTURE SHOWN BY LIGNITE BED IN SOUTHEAST-} ERN PART OF WARD COUNTY

The Coteau lignite bed of the Fort Union formation is exposed about 8 miles southwest of Sawyer. The writer's interpretation, based partly on data gathered by him and partly on reported information from several sources, is that the bed dips to the northeast and is cut by small faults. About 1 mile northeast of the escarpment of the Coteau du Missouri the bed is at an altitude of about 1,930 feet. Three miles farther northeast it is at an altitude of less than 1,800 feet. There are indications also of fairly numerous local folds of very small amplitude, and of minor faults. Small faults that trend northwest are reported in mine workings; other small faults and synclines are indicated to trend about at right angles to these and control the trend of secondary tributaries. The mine workings are on a bedrock bench 1-2 miles from the escarpment of the Coteau du Missouri and, therefore, the faults occupy a topographic and possibly stratigraphic position similar to that which characterizes similar deformation near the town of Lignite ('Townsend, 1950 , p. 1552-1564). This similarity is particularly suggestive, inasmuch as the bedroock bench appears to be more or less continuous near the edge of the Coteau du Missouri between these two areas.

\section{DIP OF A SANDSTONE BED IN THE FORT UNION FORMATION NEAR VELVA}

Sandstone that crops out in some coulees 1-3 miles southwest of Velva has an apparent dip to the northeast of about 20 feet per mile. This is less than half the dip indicated by outcrops of the Coteau lignite bed about 8 miles to the southwest. The decrease in dip and the near horizontality of the strata still farther from the escarpment of the Coteau du Missouri suggest that dip of beds is greatest near the escarpment of the Coteau du Missouri and decreases to almost nil in a distance of about 10 miles from the escarpment.

\section{DIRECT EVIDENCE OF STRUCTURE IN ADJACENT AREAS}

\section{AREA NEAR LIGNITE}

Folded and faulted beds of the Fort Union formation are exposed in a zone about 7 miles long and 1 mile wide, $5-\bar{\tau}$ miles southwest of the town of Lignite. The deformed beds, which were looked at several times by the writer and have been described in detail by Townsend (1950, p. 1552-1564), are exposed in and near coulees incised in a topographic bench below and parallel to the escarpment of the Coteau du Missouri. 
The exposed structures as described by Townsend are a complex of relatively small folds and faults of various shapes and closures. The general trend of the strikes is $\mathrm{N} .74^{\circ} \mathrm{W}$, but variations of $10^{\circ}$ in either direction are common, and a few beds strike as much as $90^{\circ}$ from the general trend. Some beds trending widely from the dominant strike are parts of the ends of anticlines or synclines. Asymmetric, close-plunging folds are common. Small, high-angle thrust faults show displacements of 1-10 feet, and faults of greater displacement are inferred from variations in dip of adjacent beds.

\section{NESSON ANTICLINE}

The Nesson anticline, where oil was found in 1951, is approximately in the middle of the Williston basin, in McKenzie County about 80 miles west of Minot. The anticline was first described by Collier (1918, p. 211-217), later by Nevin and Laird (1946, p. 1-24), and still later by Laird and Towse (1951, sheet 1 ). Their work shows that the Nesson anticline is a structural nose plunging southward, and that the south end is a dome with some closure. This dome is known as the Keene dome.

According to Laird and Towse there are other smaller anticlines in Emmons County, in the southcentral part of North Dakota, that parallel in general direction the southeast trend of the Cedar Creek anticline in western North Dakota and eastern Montana.

\section{STR UCTURE IN KNIFE RIVER AREA}

Benson (1951, map), in mapping the surface structure in the Knife River area, about 50 miles south of Minot, showed the strata in that area are gently folded into small domes and synclines. In the southern part of that area, the beds, in general, dip about 15 feet per mile to the north or northwest. In the northern part of the area, they are nearly flat (Benson, 1952, p. 229).

\section{FAULT BLOCK AND OTHER STR UCTURE IN SOUTHERN SASKATCHEW AN, CANADA}

Fraser and others (1935, p. 59-62), have described the structure of southern Saskatchewan. It appears to be similar to the structure described by Townsend (1950, p. 1552-1564), near the western edge of the Souris River area. Frazer's map shows a long southeast-trending fault along the northeast escarpment of the Cotea du Missouri, about 25 miles southeast of Moose Jaw. If this fault extended about 110 miles to the southeast, it would pass a few miles south of the deformation described by Townsend. The existence of this fault is inferred by Fraser and others (1935), inasmuch as beds of the Ravenscrag formation (in part equivalent to the Fort Union formation) decrease in altitude to the east of the escarpment about 400 feet in $1 \frac{1}{2}$ miles. This notable decrease in altitude, together with the absence of exposed tilted beds is attributed to a fault downthrown on the east side.

Although the considerable distance between the Saskatchewan fault and the deformation near Lignite makes extrapolation between the two areas hazardous, the general settings have much in common. Both structures are at the edge of and parallel to the northeast escarpment of the Coteau du Missouri. Both have nearly the same strike and both have higher bedrock on their southwest sides.

The fact that there is good evidence in Saskatchewan that the fault block is downthrown to the northeast suggests at once not only that the escarpment of the Coteau du Missouri in the Saskatchewan area is a fault scarp, but that the same may be true in the Lignite area and in the Souris River area where the Coteau du Missouri owes its prominence to high underlying bedrock.

Fraser and others (1935) believe that the regional structure of the southern 50-miles-wide strip of Saskatchewan dips gently east or northeast. They interpret this area to be the west side of a very broad shallow trough, the east side of which is in southwestern Manitoba. On this regional structure, they believe, are superimposed irregular minor structures which include abrupt flattening and steepening of dips and minor faults and undulations. Although conclusive evidence is lacking, this regional structure may possibly continue into the Souris River area. In the Souris River area, dips to the northeast appear to be greatest immediately northeast of the escarpment of the Coteau du Missouri, then they flatten out away from the escarpment in a northeasterly direction, and (as will be discussed later) rise in the vicinity of the Turtle Mountains. The resulting broad and shallow southeast-trending trough may have its axis nearly coincident with the east loop of the Souris River.

\section{DIP OF LIGNITE BED SOUTHEAST OF MAPPED AREA}

Abont 20 miles southeast of the mapped area, along the shore of Coal Mine Lake in sec. 33, T, 149 N., R. 74 W., a lignite bed of the Fort Union formation has an apparent dip to the northwest. No measurements were made of the dip but it is estimated to be about two degrees. This outcrop is only about 2 miles from the northeast-facing escarpment of the Coteau du Missouri.

\section{DEFORMATION OF COLGATE MEMBER OF FOX HILLS(?) SANDSTONE SOUTHEAST OF SOURIS RIVER AREA}

Considerable deformation is exhibited by the Colgate(?) member of the Fox Hills(?) sandstone exposed in a railroad cut in Pierce County, about 20 miles 
east of Balfour in the SW1/4 sec. 13, T. 151 N., R. 74 W. Superficially it appears that about 7 () feet of white sandstone forms a tight fold or dome. In the north side of the cut the beds appear to form a complete arch to possibly form a northward-trending anticline. Closure of the beds is about 70 feet where the limbs along the base of the cut are about 200 feet apart. Some intraformational deformation also appears to be present in these beds. More detailed work is necessary before this type of structure and the regional structure of this area can be explained.

\section{PROBLEMATICAL AND INDIRECT INFERENCE OF STRUCTURE WITHIN AND ADJACENT TO THE MAPPED AREAS}

STEEP DIP OF LIGNITE BED WEST OF MAPPED AREA

Leonard and Eaton $(1925$, p. 80$)$ measured steep dips in the Fort Union formation about 7 miles south of Alkabo, N. Dak., which is about 65 miles west of Lignite. Part of their description follows:

The coal bed mined about 7 miles south of Alkabo... is of considerable interest on account of the steep inclination of the bed. . . . Dips as high as $23^{\circ}$ and $30^{\circ}$ to the north or northwest were measured, and a dip of $45^{\circ}$ is reported. . . The lignite bed continues but a short distance in the direction of the dip and is reported to end suddenly against a nearby vertical wall of clay. ... The dip of this bed may . . be the result of folding, the tilted strata being a portion of the northward dipping limb of an anticline. Another possibility is that a large block or section of the strata slumped down from a formerly southward facing escarpment. . . I It should be stated, however, that there is little evidence of shmping on such a large scale.

If the steep tilt of the beds near Alkabo is due to tectonic deformation, the fact is established that beds of the Fort. Tnion are tilted at high angles in at least one place near the mapped area other than the place near Lignite. This supposed deformation is near the center of the Coteau du Missouri, which indicates that there is deformation on top as well as along the margin of the Coteau du Missouri.

\section{INFERRED STRUCTURE IN KIDDER COUNTY}

Beds of Fox Hills sandstone about 60 miles southeast of the mapped area, in a range of hills near the south end of Horsehead Lake in Kidder County, dip about $45^{\circ}$ to the northeast. The attitude of the beds may conceivably be due to ice shove, but it is unlikely that deformation of this magnitude is attributable to this cause. The tilted beds occupy a position on the Coteau du Missouri similar to the tilted beds near Alkabo. This suggests that, if the deformation at these two localities is of a tectonic nature, there was widespread tectonic disturbance on and adjacent to the Coteau du Missouri.

\section{STRUCTURE INFERRED FROM THE LOCATION OF} SPRINGS AND ARTESIAN WELLS

Lignite beds are the chief aquifers in the Fort Union formation. Springs issue from lignite beds that have been truncated by erosion, along the valley walls of the Des Lacs River, and to a smaller extent along the Souris River valley between Burlington and Sawyer. Although there are large springs along the south and southwest valley walls, there are almost none on the north and northeast valley walls. The water probably flows along northeast-dipping lignite beds, and the beds probably are recharged from the numerous undrained depressions and ponds on the Max moraine a few miles to the southwest. In addition, numerous artesian wells issue from lignite beds in the area between Minot and the escarpment of the Max moraine and also in the area between Kenmare and the Max moraine. If the water-bearing lignite beds dip northeast as supposed, they can be recharged easily from the numerous ponds and small lakes on the Max moraine. On the other hand, if they dip in any other direction there would be little chance for recharge in the narrow strip of ground moraine between the Des Lacs and Souris Rivers.

\section{DISTURBED FORT UNION STRATA ON WEST FLANK OF} TURTLE MOUNTAINS

Laird and Towse (1951, sheet 1) report disturbed Fort Union strata from a locality about 25 miles northeast of Westhope and $r$ miles north of the town of Carberry, on the west flank of the Turtle Mountains. They believe that the disturbance can be attributed to ice shove. Although this possibility should not be ruled out, the writer has not seen any deformation of strata in the region that could unequivocally be attributed to ice shove and, consequently, is reluctant to attribute the deformation to this cause. On the other hand, if these disturbed strata do reflect tectonic deformation, part or much of the well-defined scarp of the western flank of the Turtle Mountains might reflect a fault scarp.

\section{POSSIBLE SIGNIFICANCE OF BEDROCK HIGH UNDER THE MAX MORAINE}

The Fort Union formation is higher under a large part of the Max moraine than under the groundmoraine plain. This bedrock upland may have originated in either of two different ways. The first possibility is that, prior to glaciation, erosion may have been less active in the area and left a relatively long and narrow plateau or remnants of a plateau. The second possibility is that the bedrock is higher in this area because of structural elevation, that is, diastrophic forces elevated the higher bedrock relative to the adjacent lower areas. 
In considering the first possibility, there is no reason to suppose that normal erosion of essentially horizontal strata would have left such a long, narrow divide. This is especially true when it is postulated that the preglacial Missouri, Yellowstone, and other rivers cut channels through this topographically high bedrock at the time they drained into the Hudson Bay. Moreover, normal erosion would not leave the abrupt escarpment along the edge of the Coteau du Missouri in the Souris River area.

In considering the second possibility, that of structural elevation, the presence of folds and faults on the edge of and parallel to the bedrock high near Lignite and of steeply inclined beds near Alkabo and near Horseshoe Lake in Kidder County show that there was tectonic deformation at least locally, and that it may have been widespread in the Coteau du Missouri. Some of this deformation may have elevated the area.

\section{EROSIONAL FEATURES THAT MAY BE STRUCTURALLY CONTROLLED}

Several topographic features are roughly parallel with or are so oriented to the general strike of folds and faults in a till-veneered bedrock bench near Lignite that a relation is implied between these topographic and structural features.

The bedrock bench where the deformed beds are exposed is parallel to and adjacent to the proximal border of the Max moraine, which, in this area, is roughly parallel to the trend of strike of the deformed beds. Most coulees incised in the bench trend down the bench slope to the northeast. Howerer, segments of many coulees are parallel to the bench length and to the border of the Max moraine. Many small secondary coulees enter larger ones from directions perpendicular to the general northeast trend of the larger coulees and parallel to the general strike of the bedrock. Also tiny, incipient drainage courses or shallow depressions trend down the bedrock bench slope, thinly covered with ground moraine, and cross similar incipient drainage courses nearly at right angles. These slight crosstrending depressions collect enough surface runoff to support more regetation than surrounding areas and show on aerial photographs as "streakiness" parallel to the strike of folds exposed in nearby bedrock. The trend of segments of the larger coulees and that of the secondary conlees and other incipient drainage courses suggest that underlying structure is controlling the drainage pattern and may be considerably more widespread than is indicated by exposed deformation.

Other erosional features that might reflect structure are steep-walled basins at the heads of some of the coulees. Here, headward erosion has stopped in faror of sapping by springs and erosion by surface drainage parallel to the strike of the bedrock. The resulting depressions are roughly oval. Althongh erosion in the basins is working along the strike of the bedrock, it is not clear whether it is caused by dipping of the strata or merely by the presence of weak beds or truncated aquifers on the northeast sloping eroded bedrock surface.

\section{POSSIBLE STR UCTURE OF THE BOTTINEAU COUNTY GAS FIELD}

Simpson (1929, p. 81) briefly described a supposed anticline, which is $\mathbf{V}$-shaped in plan, one point near Deering and the sides extending to the International Boundary, between the towns of Westhope and Sherwood. Several producing gas wells were drilled in this supposed structural feature in the early part of this century. The drills cut through a thick section of drift and struck gas almost immediately upon penetrating bedrock. Simpson based the outline of the suspected anticline on the areal extent of the producing wells. He also mentioned a few weakly flowing water wells between Antler and Hurd (about 7 miles northeast of Lansford), which, he suggested, show the presence of a very gentle syncline within the broad curving anticline of the gas field. He believed that the syncline trends from Hurd slightly west of north across the International Boundary near Antler. The writer has no information to help prove or disprove this supposed structure; if it does exist, it is compatible with the inferred regional structure and represents one or more minor northwest-trending gentle folds.

\section{POSSIBLE STRUCTURE BASED ON TOPOGRAPHIC POSITION OF FORMATIONS IN DIFFERENT PARTS OF THE MAPPED AREA}

The pancity of bedrock outcrops and subsurface data in the Souris River area prechudes all but the broadest. structural generalizations that are based on the topographic position of the different strata. $\Lambda$ few outcrops and data based on well samples, however, permit some speculation.

In the vicinity of Sawyer the top of the Cannonball member of the Fort Union formation is at an altitude of about 1,540 feet. The highest foraminifera identified from the Cannonball member, in the .J. H. Kline well, $31 / 2$ miles southeast of ('arpio, are at an altitude of 1,329 feet. The top of the Cannonball in the Des Lacs Western well is not known with certainty but is somewhere below a thick lignite bed that occurs at an altitude of 1,387 feet.

In the vicinity of Verendrye, in the southern half of McHenry County, the top of the Cannonball member is at an altitude of $1,5+0)$ feet. Howerer, if an exposure of bedrock in the NW1/4 sec. 6 , T. $151 \mathrm{~N}$., R. $7 \tau \mathrm{W}$. has been identified correctly as 
Cannonball strata, this formation extends to an altitude of at least 1,600 feet. In the area from Verendrye northwest to the International Boundary, it is inferred that the top part of the formation was removed by erosion; but the original total thickness of the formation probably did not greatly exceed 40 feet, and the altitude of the top can be estimated from altitude of the strata remaining. These remaining strata probably lie at an altitude of about 1,300 feet and the restored top of the formation is probably not much higher. In contrast, Cannonball foraminifera were positively identified from the west flank of the Turtle Mountains, in the NE1/4 sec. 17, T. 163 N., R. 76 W., at an altitude of about 1,950 feet. Benson (1952, p. 233) found the top of the Cannonball at an altitude of 1,430 feet at Garrison Dam (about 50 miles south of Minot), at 1,685 feet east of the town of Stanton (about 15 miles southeast of Garrison Dam) and at 1,430 feet at Washburn (about 35 miles southeast of Garrison Dam).

Summarizing: In the Souris River area, the Cannonball member is highest adjacent to the Coteau du Missouri; thence the dip flattens to the northeast to its probably lowest point, in the area extending northwestward from Verendrye to the International Boundary. Northeast of that area the strata rise toward the Turtle Mountains.

SUMMARY OF STRUCTURAL EVIDENCE IN SOURIS RIVER AREA AND ADJACENT AREAS

The following suppositions are drawn from direct evidence in only a few localities, because surficial deposits nearly everywhere cover the bedrock. The inferences are even more questionable because of possible alternate explanations. Therefore, the suppositions are tentative and are subject to revision. Also, it is unlikely that the surface structure is a reflection of structure at considerable depth.

Most of the area is interpreted to lie within a broad shallow northwest-trending syncline that extends into Canada. The axis of the syncline may extend from the town of Towner, northwestward to and beyond Antler. Within this trough minor folds and undulations probably trend northwest. One limb of the syncline is inferred to extend to the Coteau du Missouri. The Turtle Mountains, perhaps, reflect the extension of the other limb. Along the northeast escarpment of the Coteau $\mathrm{du}$ Missouri, folding and faulting probably extend many miles on a bedrock bench parallel to the escarpment. This structure decreases in magnitude northeast of the escarpment and is expressed for the next few miles thereafter chiefly by a gentle dip of $1 / 2^{\circ}-2^{\circ}$ to the northeast. Within 10 miles of the escarpment, the beds are near horizontal.
The escarpment of the Coteau du Missouri along much of its length may be a fault scarp downthrown to the northeast. This supposition is based upon the following lines of evidence: (a) the presence of probable long fault block, downthrown to the northeast along the escarpment of the Coteau du Missouri in Canada, (b) the remarkable straightness of the escarpment itself, and (c) faulting and folding in the bedrock bench adjacent to the escarpment. The topographically high Coteau du Missouri may also have been uplifted and steeply dipping bedrock on top indicate that the strata may be folded and faulted.

\section{PRE-PLEISTOCENE AND PLEISTOCENE DRAINAGE}

Before the last glacier covered the Souris River area and vicinity, the drainage pattern was much different than it is today. Most of these drainage courses are now almost or completely filled with younger deposits. Some channels are preglacial stream courses; others are glacial courses that existed before the Mankato substage. The supposed courses of the channels are shown in plate 14. Those channels formed by melt waters of the Mankato substage of glaciation are discussed on pages $113-114$.

Flint (1949b, p. 68) has shown by his work in South Dakota that the Cheyenne River and all streams north of it in South Dakota flowed into the Hudson Bay in preglacial time. Of the streams that flowed northward, the ancestral Missouri and Yellowstone rivers might have flowed west of the Souris River area and the ancestral Knife River might have flowed northward through the eastern part of the mapped area.

Alden (1932, pl. 1) showed that the preglacial Missouri and Yellowstone trended across the extreme northwest part of North Dakota, possibly to join west of the Souris River area. He postulated that a reentrant in the proximal edge of the Max moraine, about 15 miles west of Crosby, marks a segment of the course of the ancestral Missouri River, whereas a similar reentrant in the Max moraine, directly south of Crosby, marks the buried ancestral Yellowstone River. Drilling records and other data, furnished by Witkind (1949, written communication), support a belief that a large buried channel, presumably the ancestral Missouri, extends northeastward from the vicinity of Medicine Lake in northeast Montana. Drilling by the U.S. Bureau of Reclamation near ('rosby shows that a deeply buried valley trends northeastward from the reentrant shown by Alden as marking the course of the ancestral Yellowstone River. However, it is not known whether this buried valley extends completely through the Max moraine or whether the stream that occupied this valley flowed northeastward or southwestward, but because 
of data collected by other workers already cited, a stream flow to the northeast into Canada is favored.

Benson (1952, p. 165-175) reconstructed the pre-Recent major drainage pattern in the Knife River area. He concluded, as had Flint for areas in South Dakota, that the preglacial streams in the Knife River area flowed eastward across what is now the Missouri River trench and northeastward into Canada. Benson and the writer traced the probable course of the ancestral Knife River northeastward from near Garrison Dam, where a broad shallow trench extends east from the Missouri River in line with the Knife River valley, for about 15 miles. Beyond there the old course is largely obscured by drift but appears to continue eastward and then northeastward, past Picardville and McClusky, to cross the Coteau du Missouri through a comparatively low sag known as the Lincoln Valley sag (see pl. 15). Beyond the Lincoln Valley sag, the buried course may trend northeastward to join the old valley now occupied by Devils Lake, or it may turn northwestward toward the Souris River. The latter course is favored. In a drill hole 10 miles southwest of Harvey, in a glacial diversion channel connecting the Sheyenne River and the headwaters of the James River in NE1/4 sec. 17, $\mathrm{T}$. 148 N., R. $73 \mathrm{~W}$., bedrock was penetrated at a depth of 25 feet. In a second hole in the bottom of the Sheyenne River valley, about 6 miles southwest of Harvey in the NE1/4 sec. 34 T. 149 N., R. 73 W., bedrock was penetrated at a depth of 20 to 30 feet. Hence, bedrock underlies the present valley floors at shallow depth. By contrast, in a hole drilled in the floor of a diversion channel about 10 miles southwest of Anamoose, in sec. 6, T. 149 N., R. 75 W., 240 feet of surficial deposits was penetrated before bedrock was entered at an altitude of about 1,360 feet. This great depth suggests that a buried valley trends from the Lincoln Valley sag northeastward through this point. From this point northward to Towner, the supposed course is based on very scant data. However, a few doubtfully reliable well logs and inference based on landforms and exposures of bedrock elsewhere in the area indicate that the channel may continue northward between Drake and Anamoose, to a point about 8 miles south of Towner. Water-well $\operatorname{logs}$ and other drilling definitely support the inference of the presence of a bedrock trough trending northwestward from near Towner to the International Boundary in the vicinity of Antler. Although this trough might be structural, it is likely that it also served as a preglacial drainage course and nay have contained the waters of the preglacial Knife River. The bedrock floor is 200 to 275 feet beneath the present surface. It is west of and roughly parallel to the present course of the east loop of the Souris River. The present Souris River in this area, although lying in the bottom of a topographic trough, is actually underlain by a bedrock surface that slopes gently to the southwest. (see pl. 2 ).

Some channels that carried glacial melt waters in pre-Mankato time probably did not exist prior to glaciation in the area, except possibly for small segments. The present valley of the Des Lacs River and part of the valley of the Souris River were formed in preMankato time but probably did not exist in pre-Pleistocene time.

The valley floor of the Des Lacs River is incised in bedrock and bedrock extends about a third of the way up the valley walls above the present alluvial floor. Exposures of bedrock are scarce, however, because a relatively thin veneer of till has been deposited over the bedrock and extends beneath the present alluvial floor. The presence of this till in the valley, topographically lower than the bedrock, indicates that the valley is older than the Mankato substage or that a readvance of the ice deposited the till in the valley after the melt waters of a first advance had scoured out the valley. There are at least two reasons for believing that the valley is pre-Mankato. Till not only drapes over bedrock but also underlies thick sections of glacial outwash in the valley bottom (see fig. 16). Such a thick section of outwash probably would not have been deposited between two small advances of the same ice sheet. Also, if till that underlies the boulder belt in the valley $1 \frac{1}{2}$ miles southeast of Donnybrook is older than Mankato substage, as believed, there is almost unequivocal proof of pre-Mankato age for at least that segment of the valley. This is indicated by the fact that nearby bedrock is topographically higher than this till, which strongly suggests that the till was deposited in a preexisting valley. If the till below the boulder bed is as old as the Iowan substage, the valley may be of pre-Wisconsin age. It does not appear likely though that the entire length of the valley was formed in preglacial time, because water would have had to flow in the opposite direction from the other master streams of the region, which were flowing northward toward the Hudson Bay (see pl. 14). Moreover, the regional slope of the bedrock surface is northeast, whereas the trend of the valley is at right angles to this slope so that the trend roughly contours the regional slope. However, it is possible that segments of the valley may be preglacial and may have drained in a direction opposite the present drainage. Some evidence to support this possibility is found in the part of the valley upstream from Kenmare.

The Souris River valley, above its confluence with the valley of the Des Lacs River, was apparently not 
incised in bedrock except for the first few miles above the confluence. In most places, the valley fill extends just to topographically flat bedrock. Like the valley of the Des Lacs River, the valley trends at right angles to the slope of the bedrock surface. As indicated from the glacial history of the area, melt waters of the Mankato ice were diverted by the ice front from the part of the valley of the Souris River just north of the Intermational Boundary and through a shallow diversion channel into the Des Lacs River. As the ice front retreated, the downstream part of the Souris River was uncovered and the diversion channel was abandoned in favor of this lower chamnel. That the lower channel existed before the area was uncovered by the last ice sheet seems likely, inasmuch as there appears to be no reason why the melt waters would not otherwise have continued to flow through the diversion channel. Therefore, the segment of the Souris River valley above its confluence with the Des Lacs River appears to be pre-Mankato but not pre-Pleistocene.

The segment of the Souris River from the confluence with the Des Lacs River downstream to Verendrye is entrenched in bedrock. Bedrock, in most places, extends about a third of the way up the valley walls above the present alluvial floor. As in the valley of the Des Lacs River, till drapes over the bedrock of the valley walls and at least in places underlies thick deposits of glacial outwash in the valley bottom. The history of this part of the valley is apparently similar to that of the Des Lacs River, inasmuch as it is a continuation of that valley. But part or most of this segment of the valley might also have existed in preglacial time and might have been a tributary to the supposed preglacial Knife River, whose channel is believed to cut across the Souris River valley a few miles below Verendrye. The valley between Velva and Verendrye is concordant with the slope of the bedrock surface and, thus, could hare been a tributary to the supposed preglacial Knife River. Water-well data obtained at Minot shows that the bedrock floor in one place is 248 feet below the present alluvial floor, which is a greater depth than is indicated downstream by drilling in the ricinity of Sawyer. If so, a buried ralley may cut northward across the present valley in the ricinity of Minot, or a deep gorgelike valley not encountered in drilling near. Sawyer may extend downstream.

From Towner downstream, the Souris River valley is probably nowhere entrenched in bedrock, except possibly at the International Boundary, where bectrock is about 47 feet below the present allurial floor. The fact that this segment of the ralley is not cut in bedrock, added to the fact that the valley is nearly normal to the slope of the bedrock surface, precludes a preglacial existence for the valley.

Segments of other buried channels cross the Souris River area. Most of these cannot be traced more than a few miles, and it is not known whether they are preglacial or glacial in origin. Some channels are indicated where drilling has shown that the depth to bedrock is considerably greater locally than in surrounding areas. Sags in the ground surface indicate other partly buried channels.

A buried channel in the Max moraine along the western edge of Ward County and about 6 miles southeast of Tagus is indicated by a fairly pronounced elongated sag. The sag extends from Carpenter Lake to the northeast escarpment of the Max moraine. Additional evidence of a buried chamnel is furnished by the fact that Carpenter Lake is saline. Witkind (1958) and the writer believe that chains of saline lakes along topographic sags in this region represent buried channels. Whether the channel near Tagus is preglacial or glacial has not been determined; neither has the direction that the water flowed. Other chains of lakes extending entirely across the Max moraine to the south of Carpenter Lake may mark continuations of the buried channel. However, no indication has been found that the channel extends northward beneath the ground-moraine plain.

Other elongated sags extend to the northeast escarpment of the Max moraine in the vicinity of Kongsberg and Ruso (pl. 1). Andrews (1939, p. 65) believed these sags were branches of a spillway which carried overflow waters of glacial Lake Souris across the moraine to the Missouri River to the south. However, the writer believes that glacial Lake Souris, at its highest level, was about 550 feet lower than these sags. Moreover, it is probable that no melt waters drained from the heads of these channels during the deglaciation of the last ice sheet, as indicated by the lack of outwash in the floors at the heads of the sags; instead, the sags contain hummocky knolls and undrained depressions, identical in form and composition to the Max moraine itself. The segments of the sags near the escarpment evidently represent pre-Mankato channels partly buried under Mankato till although a few miles to the south, segments of these sags carried glacial melt waters of the Mankato ice sheet, as shown by the fact that they are flat floored and contain outwash. The buried segments of the channels probably are not preglacial channels because subsurface data, although not inequivocal, suggest a very abrupt break in slope of the bedrock surface all along the front of the escarpment in this area (see pl. 2). This would prechude southward drainage; streams draining to the south and 
any streams draining northward would have to flow over a steep fall line without entrenching deep valleys. The partly buried segments of the channels were probably cut when the front of a pre-Mankato ice sheet stood along the escarpment, causing melt waters to flow off it and erode the channels.

A large reentrant in the Max moraine in T. $151 \mathrm{~N}$., R. 82 W. (pl. 1) may indicate a buried channel, but because of many bedrock outcrops in the area of ground moraine, such a channel must trend northwestward from the reentrant, if it does exist. However, a possible course in this direction is also hard to postulate because of the shallowness of bedrock in many places in that area.

\section{SUMMARY HISTORY OF PLEISTOCENE DEPOSITS SETTING PRIOR TO GLACIATION}

After the Paleocene epoch, the land began to rise slowly. Streams grew in size as the swamps and lagoons gradually drained. Then followed a long period of erosion. The duration of the erosion interval is not known but possibly it extended from Paleocene to Pleistocene time, inasmuch as no deposits of the intervening time exist in the mapped area. The Golden Valley formation of Eocene age was laid down in the Knife River valley in west-central North Dakota (Benson and Laird 1947, p. 1166-1167) but it has not been recognized northeast of the Coteau du Missouri and may never have been deposited. Flaxville gravel of Miocene or Pliocene age is widespread in northeastern Montana, but the easternmost exposure is near Alkabo, N. Dak., about 70 miles west of the mapped area. It seems unlikely that these deposits ever extended across the Coteau du Missouri.

\section{SETTING DURING GLACIATION}

\section{SYNTHESIS OF GLACIAL HISTORY IN SOURIS RIVER} AREA AND VICINITY

On the basis of work by Benson (1952, p. 18t-194) to the south, it is judged that all four ice sheets of the Wisconsin stage probably passed over the Souris River area. However, the drift of Mankato substage everywhere overlapped the older drifts in the Souris River area. Thus, all the surface drift belongs to this substage except for a few exposures of till that have been exposed by erosion along the valley walls of the Des Lacs River that are believed to be of the Iowan or Tazewell substage.

The general over-all advance of the ice of the Mankato substage in North Dakota is believed to have been from the northeast. During late Mankato time, however, two separate ice lobes advanced into north-central North Dakota. One lobe, hereafter called the Leeds lobe, is believed to have advanced around the east flank of the Turtle Mountains and spread ont to the southwest, whereas the other lobe, hereafter called the Souris River lobe, advanced directly from the northwest. The orientation and association of features shown on the physiographic map (see pl. 15) form the basis for much of this intrepretation.

The positions of the features shown in the eastern half of plate 15 were compiled from reconnaissance work by R. B. Colton and the writer, from interpretation of aerial photographs and from work of Branch (1947, map), Easker (1949, map), Tetrick (1949, map), and Aronow, Dennis, and Akin (1953, opposite p. 6). It should be emphasized that most of this area has not been mapped in detail and therefore, the map is generalized and locally may be in error.

As shown on plate 15 , most of the large end moraines east of a line drawn south from the east end of the Turtle Mountains trend in a southeasterly direction and indicate a recession of the ice front to the north and northeast. These features were deposited, at least in part, by the Leeds lobe. This retreating ice front was distinctly lobate, as shown by the crescentic pattern of arcuate "washboard" moraines that mark cyclic stillstands of the ice front. These washboard moraines are transverse to parallel grooves and drumlinoidal ridges and indicate that the ice melted back in the direction from which it advanced. Some features in the area northeast of Devils Lake, shown as end moraines by Upham (1896, map opposite p. 170), trend nearly due south. An examination of aerial photos indicates that these features are not end noraines but are interlobate moraines formed between coalesced minor lobes. Only the best-formed washboard moraines are shown on plate 15 ; many are too indistinct to plot accurately.

Retreat of the ice margin to the north and northeast, in the eastern part of the area shown in plate 15, is also shown by the position of outwash channels and of spillway channels that partly drained glacial Iake Souris. The general slope of the surface in that area is northeast, yet most of the channels trend in a southeasterly direction or almost at right angles to the regional slope. This indicates that they were mostly marginal to a northward receding ice front. From their pattern, in respect to the topography, it is evident that the southernmost channels were first abandoned, in faror of successively lower channels to the northeast, as the ice front retreated in that direction.

The Souris River lobe adranced from the northwest across the Souris River area at about the same time or a little later than the Leeds lobe advanced around the east flank of the Turtle Mountains. The interpreted 
limits of the Souris River lobe are marked approximately by a wide belt of morainal topography that stretches southward from the southeast corner of the Turtle Mountains to the top of the Max moraine in the vicinity of Lincoln sag. This morainic belt hereafter is designated the Martin moraine. Locally, in an area in Lincoln sag and also southeast of Martin, ground moraine of the Souris River lobe probably extended beyond the distal edge of the Martin moraine. Its farthest southeast extent, however, is not known with certainty. As shown on plate 15, a series of well-developed washboard moraines mark its southeastern limits. Linear ridges about 10 miles farther to the southeast, which trend southeast and thereby suggest that they were formed by the Souris River lobe, are tentatively interpreted to belong to the Leeds lobe. Their anomalous trend can perhaps be explained as due to the deflection of the Leeds lobe to the southeast as it approached the escarpment of the Max moraine. If these linear ridges were assigned to the Souris River lobe, it would not be clear how a narrow lobe of ice could have advanced so far along the escarpment of the Max moraine without also advancing downslope to the northeast.

West of the Martin moraine, the drumlinoidal features trend southeast and indicate an ice advance from the northwest. Arcuate washboard moraines and associated arcuate undrained depressions transverse to these drumlinoidal features indicate that the front of the Souris River lobe retreated northwestward.

The Souris River lobe was thin enough during its latest phase, so that the Turtle Mountains acted as a buttress and deflected the ice. However, an indistinct lobate pattern of recessional ridges on the western part of the Turtle Mountains suggests that at least this part of the mountains was covered by the Souris River lobe at one time. The tops of the mountains were freed of ice first, as indicated by the presence of a kame terrace that flanks the south edge of the mountains. By the time the kame terrace was formed, the Souris River lobe was probably confined to the area between the Turtle Mountains and the Coteau du Missouri.

The Souris River lobe appears to have overridden the northwest segments of the end moraines deposited by the Leeds lobe. This is indicated by the apparent truncation of the end moraines of the Leeds lobe by the Martin moraine of the Souris River lobe. Also a morainal area north of Knox, crested by sets of washboard moraines that are randomly oriented, probably reflects overlapping of that area by the two lobes. This overlapping probably represents minor fluctuations of the ice fronts of both lobes during recession, because the positions of glacial outwash channels and spillways of glacial Lake Souris strongly support the assumption that the Leeds lobe occupied the eastern part of the area shown on plate 15, while the Souris River lobe was in existence. Several outwash channels and spillway channels head in the Souris River lobe area. Their courses beyond the distal margin of the Martin moraine are approximately normal to the regional slope and, therefore, must have been marginal to the Leeds lobe. A good example is furnished by the spillway that headed at Girard Lake and drained glacial Lake Souris. Glacial Lake Souris lies entirely within the influence of the Souris River lobe. Yet, when the spillway waters passed beyond the distal margin of the Martin moraine, they flowed at first through the North Fork of the Sheyenne channel and then through the Heimdal diversion channel, which, in turn, emptied into the James River. It was not until the front of the Leeds lobe receded to the north that this channel was abandoned in favor of the lower channel, which drained down the Sheyenne River.

The work of J. A. Elson in Manitoba, north of the Turtle Mountains, supports the existence of the Souris River lobe and the Leeds lobe in North Dakota. According to Elson (written communication), the area of ice nourishment shifted from west to east in late Mankato time. Washboard moraines, drumlinoidal features, eskers, and other evidence show that ice in Manitoba that advanced from the northwest split into two lobes when it reached the north flank of the Turtle Mountains. One lobe, the Souris River lobe, advanced into the Souris River area. The other lobe advanced around the east flank of the Turtle Mountains and appears to have continued into North Dakota as the Leeds lobe. Elson, however, also found that a lobe of ice advanced from the north or northeast nearly to the north flank of the Turtle Mountains. This lobe existed at about the same time as the lobe that advanced from the northwest and may have advanced into North Dakota east of the Turtle Mountains. If so, some of the recessional features attributed to the Leeds lobe might represent that advance. Certainly, some of the drumlinoidal ridges in the southeast part of the area shown in plate 15 indicate an ice advance from the northeast.

\section{GLACIATION DURING MANKATO SUBSTAGE IN SOURIS RIVER AREA}

For convenience of discussion, the glacial history of the Mankato substage in the Souris River area is divided into the Mankato glacial history of the Max moraine and the Mankato glacial history of the area northeast of the Max moraine. 


\section{MAX MORAINE}

The orientation of end moraines, drift borders, and other glacial features indicate the ice of the Mankato substage at its maximum in North Dakota advanced from the northeast. The Max moraine is a special type of end moraine of that glaciation.

The advancing ice sheet of the Mankato substage, upon reaching the till-veneered bedrock escarpment of the Coteau du Missouri, had to overcome an obstruction of large magnitude before being able to continue its advance. The ice had to reach a thickness of several hundred feet in front of the escarpment before this was possible and the basal part of the ice had to move upslope most of the way to the escarpment. As a result, the ice probably became heavily charged with debris with which it came in contact. Some of this material, such as erratics of carbonate and granitic rocks, was transported from areas far to the north. Most of the fines, however, were scoured from the nearby overridden bedrock or from older till sheets.

During late Mankato time the Souris River lobe advanced locally over the deposits laid down earlier by the general advance of ice from the northeast.

During deglaciation of the earlier Mankato ice and locally of the later ice of the Souris River lobe, much englacial and superglacial debris was deposited haphazardly. Blocks and masses of ice were wholly or partly buried in the debris; upon melting, they produced kettles, other types of undrained depressions, knobs, and irregular ridges. The uneven topography of the Max moraine resulted.

\section{AREA NORTHEAST OF MAX MORAINE}

In late Mankato time, the Souris River lobe covered all of the area between the Max moraine and the Turtle Mountains. However, it is not clear whether the Souris River lobe and the Leeds lobe represent recessional phases of the main Mankato ice sheet or whether they represent readvances of the Mankato ice sheet after its front had receded some distance into Canada. The terminus of the Souris River lobe is believed to be marked by the Martin moraine, which extends from the southeast end of the Turtle Mountains to the Max moraine in the vicinity of the Lincoln sag. The trend of this moraine is distinctly concave to the northwest and suggests an advance of the ice lobe from the northwest. However, some drift along its eastern margin may represent interlobate deposits laid down partly by the Leeds lobe. More convincing proof of the direction of ice movement in the Souris River area is afforded by southeast-trending linear glacial ridges and grooves in the area southeast of the Souris River.
These ridges are believed to be drumlinoidal features formed at the base of the last advancing ice sheet and parallel to the direction of that advance. The parallel grooves in the intervening ground moraine are likewise believed to have been formed by the advancing ice sheet. Low arcuate washboard moraines concave to the northwest in the same area mark halts of the ice front during its retreat to the northwest. Hence, in this one area, there is good evidence for an advance of the Souris River lobe from the northwest and a retreat of the ice front of that lobe to the north west.

During deglaciation, the escarpment of the Coteau du Missouri was probably the first strip of land to emerge from beneath the southwest side of the melting Souris River lobe. Probably much of the escarpment in the mapped area became exposed at about the same time. If so, when the southwest side of the lobe had melted back a short distance northeastward, one would expect that melt water would have collected in the area between the ice front and the escarpment and escaped by flowing southeast along the escarpment. There is little or no evidence, however, that this took place. Nowhere along the escarpment are there channel remnants such as would have formed if melt water had flowed along the escarpment. In places the escarpment is sufficiently abrupt to suggest that it marks the position of a scoured channel wall, but this abruptness is probably a reflection of a sharp break in slope of the bedrock that underlies a thin mantle of drift. Likewise the surface of the lobe was probably not high enough to permit the water, trapped between the ice and the escarpment, to overflow the Coteau du Missouri, because there is a lack of outwash channels on the Coteau $\mathrm{du}$ Missouri heading along the escarpment. A few outwash channels in the Max moraine on the Coteau du Missouri drained to the south, but these head some miles southwest of the escarpment.

To account for what happened to the melt water that drained off the southwest side of the ice lobe, the writer favors the hypothesis that a belt of stagnant ice, against and parallel to the escarpment, extended back to the northeast, possibly as far as the Des Lacs and Souris River valleys. Then, as melting proceeded, this belt of stagnant ice separated completely or partly into many masses of ice, on and between which melt water flowed downslope to the Des Lacs and Souris River valleys. The trends of well-defined outwash channels west of the Des Lacs River prove drainage into that river, but it is not clear whether the outwash channels flowed along the margin of the ice lobe or between ice blocks separated from the lobe. 
Assuming that a belt of stagnant ice covered most of the area between the escarpment of the Max moraine and the valleys of the Des Lacs and Souris Rivers, a logical sequence of events during melting of the ice can be postulated. The valley of the Des Lacs River was first used as a melt-water channel for water that drained from the southwest side of the receding Souris River lobe. The valley was fed, first, by outwash channels west of the valley and, later, by a few channels east of the valley. Also, during its very early stage the valley served as a diversion channel for water that was diverted from the Souris River valley in Canada through a shallow trench (pl. 1, inset) into the Des Lacs River valley. This diversion occurred when a bend in the Souris River valley in Canada, just north of the northeast corner of Burke County, was still blocked by ice. The volume of water discharging through this trench appears to have been large for a short period of time and according to Christiansen (1956) may have taken place when glacial Lake Arcola along the south flank of Moose Mountain drained southward into the head of the valley of the Des Lacs River. At that time, a large volume of outwash-laden melt water was still flowing down Stony Run chamnel, west of the Des Lacs River in the northeast part of Burke County, and a large delta was deposited at the mouth of the channel on the floor of the diversion channel. To account for this series of events, a separate lobe of ice, probably mostly in Canada, must have lain west of the Souris River lobe and extended southward as far as Stony Run channel.

Combined outwash and diversion-channel melt waters that flowed in the valley of the Des Lacs River discharged into the Souris River valley northwest of Minot and down that valley to Velva. Inasmuch as the Souris River valley from Velva downstream was still under glacial ice when these melt waters flowed down the valley, the waters cut the Velva diversion channel, at an altitude of 1,590 feet, and through it drained away to the southeast. As melting in the downstream part of the Souris River valley continued, the Velva diversion chammel was abandoned in favor of the Lake Hester diversion channel, which, in turn, was abandoned in favor of the Verendrye diversion channel (see pl. 15). Finally, the melt waters drained at an altitude of about 1,5:30 feet directly into glacial Lake Souris, which was just coming into existence southeast of the Souris River as the front of the Souris River lobe melted to the northwest. Therefore, the earliest channel melt waters, which flowed at an altitude of 1,850 feet in the northeastern part of Burke County, were flowing at an altitude between 1,590 and
1,530 feet when they reached the area between Velva and Verendrye. This watercourse was about 100 miles long and had an average gradient of about 3 feet per mile. As the segment of the diversion channel in Burke County deepened to approximately the present valley floor level, the gradient decreased to about 2.5 feet per mile.

As the southwest side of the Souris River lobe melted back, the upper reaches of the Souris River valley, including the bend north of Burke County in Canada, were freed of ice. Water flowing down the Souris River in Canada then abandoned the high-level diversion channel that connects the Souris River valley and the head of the Des Lacs River valley and flowed instead down the Souris River valley in the northwest part of Renville County. According to Christiansen, during its late-glacial phase the Souris River partly drained glacial Lake Regina in Saskatchewan. It is not known whether melt water flowing from north of Bowbells down the Souris River valley-soon after it was freed of ice-discharged into one of the diversion channels between Velva and Verendrye, or whether it all emptied directly into glacial Lake Souris just east of Verendrye.

Inasmuch as the only outlets for melt waters flowing down the valleys of the Souris and Des Lacs Rivers were one of the three diversion channels between Velva and Verendrye, or directly into glacial Lake Souris east of Verendrye, it is evident that glacial terrace remnants in these valleys must all grade to one of these outlets. It is difficult, however, to correlate any particular terrace remnant with a particular diversion channel or with the outlet into glacial Lake Souris.

As pointed out previously, terrace remnants in the valleys of the Des Lacs and Souris Rivers might be kame terraces. If so, the melt-water streams in these valleys probably deepened their channels rapidly by melting of the ice in the channel floors. Thus, it seems likely that no one of the three diversion channels between Velva and Verendrye was in use for more than a relatively short time, before being abandoned because of channel deepening along the main valley. The Velva diversion channel was first cut by melt water diverted southeastward out of the main valley. It was then abandoned in favor of the lower Lake Hester diversion channel to the northeast which, in turn, was abandoned in favor of the still lower Verendrye diversion channel. The Verendrye diversion channel first drained southeastward through the Aylmer diversion channel into the south end of glacial Lake Souris, and later into glacial Lake Souris through the Antelope valley diversion channel. Still later, as the front of 
the ice lobe receded further northeastward, melt water flowed through the Verendrye diversion channel at Verendrye and thence into glacial Lake Souris through a broad flat watercourse northeast of Karlsruhe. Later, this channel was abandoned and water flowed down the Souris River valley directly into the lake at approximately the present mouth of the Wintering River. Sand and fine gravel extend several miles eastward from this point at about the same surface altitude. Lake deposits are present directly north of Verendrye on the north side of the river, at a surface altitude of 1,510 feet. However, the area north of the river probably was still under ice when melt waters were first being discharged into the lake in the vicinity of the Wintering River. Iater, on further recession of the ice lobe, the area north of the Souris River was uncovered. One end of a south-trending trench 5-15 feet deep ( shown by hachures on pl. 1), whose floor is at an altitude of 1,510 feet, is about 2 miles north of the present Souris River alluvium. The position and altitude of its mouth show that the stream that carved the trench was graded to another stream that flowed along the present course of the Souris River. IIowever, it is not clear whether water flowed into the Souris River valley through this trench or away from the valley.

Plate 15 shows diversion channels in the southeastern part of the mapped area and their continuation to the southeast, where they drained into the Sheyenne and James Rivers. By plotting altitudes at different points along the floors of the diversion channels, a fairly clear sequence of channel use is made evident. On the basis of altitude, the Krueger Iake spillway of Andrews (1939, p. 66), shown on plate 15 as a glacial channel about 2 miles east of town of Butte, could not, along its entire course, have drained to the southeast; hence, it was not used as either a spillway or a diversion channel to carry drainage from the Souris River valley. In the vicinity of Krueger Iake, the floor of Andrews spillway has an altitude of 1,680 feet and forms a divide between a channel (presumably an outwash channel) that drains to the northwest, and another channel that slopes to the southeast to drain into the present headwater's of the Sheyenne River. Thus, these channel segments are shown on plate 15 as ice-marginal channels.

During the earliest stages of deglaciation of the Souris River lobe, the melt water's flowed into the south end of glacial Lake Souris, through the North Fork of the Sheyenne spillway, then through the Heimdal diversion chamnel into the James River valley, to drain eventually into the Gulf of Mexico. As far as is known, that was the only time when water drained from the Souris River basin into the Gulf of Mexico. This diversion was possible only because the Leeds lobe still covered all the lower ground to the north and prevented water from flowing down the Sheyenne River valley. The front of the Leeds lobe, therefore, probably was in this vicinity when considerable shrinkage of the Souris River lobe had occurred; the southwest side of the Souris River lobe must have melted back to the Des Lacs River valley, or beyond, when the front of the Leeds lobe stood at the north side of the Heimdal diversion channel. As the Leeds lobe melted farther back to the north in this area, the lower outlet into the main valley of the Sheyenne River was uncovered, and melt waters that emptied into glacial Lake Agassiz formed well-defined terraces along the valley of the Sheyenne River south of Devils Lake and elsewhere. Thus, some of the deltas that were deposited in Lake Agassiz at the mouth of the Sheyenne River at that time probably are contemporaneous with the glacial deposits in the Souris River area and, possibly, even with those of glacial Lake Regina. Therefore, a time relation appears to be established between the glacial Lake Agassiz deposits mapped by Leverett (1932, p. 1-149) and those in north-central North Dakota, and possibly even those farther north, in Canada.

The southeast end of glacial Lake Souris was the first part of the lake to come into existence. Water flowed down the Antelope valley diversion channel and probably off the ice front itself to drain into the Aylmer diversion channel, thence into a low area immediately east of Aylmer to form the lake, as the Souris River lobe receded to the northwest. The waters ponded at a height of about 1,550 feet and possibly, for a short time, overflowed at the southeast end of the lake and drained into what is now the North Fork of the Sheyenne River.

As the Souris River lobe shrank, the northern edge of glacial Lake Souris followed the ice front back and the lake progressively increased in size. By the time the front of the lobe stood northeast of Karlsruhe, melt waters flowing down the Verendrye diversion channel emptied directly into the lake east of Karlsruhe. Later, upon further melting of the ice, melt waters emptied directly into the lake from the Souris River valley, a few miles northeast of Verendrye. Probably about this time, the Girard Lake spillway came into existence 3 miles southwest of Balta. The North Fork of the Sheyenne spillway was then abandoned and the lake drained through the Girard Lake spillway to an altitude of approximately 1,510 feet. This spillway drained into the North Fork of the Sheyenne River 
about 10 miles north of Selz. Thence, lake water drained into the Sheyenne River valley and in turn emptied into glacial Lake Agassiz. No diversion of these spillway waters into the James River valley at this time appears possible, because the floor of the connecting channel between Heimdal and Bremen is too high to have allowed these waters to pass through.

As the southwest side of the Souris River lobe continued to recede northeastward, successively lower outwash channels formed in the Souris River loop area and emptied their melt waters into the lake. The lake, in turn, increased in size as its northern margin followed the front of the ice lobe back toward the north and northwest, at least as far north as the International Border. However, the northern part of the lake must have been much more ephemeral than the southern part, as indicated by the very thin deposits on the lake floor in that area as contrasted with thicker deposits to the south.

Upon further shrinkage of the ice lobe, the low area along the Souris River valley north of the International Boundary was uncovered and the lake drained northward into Canada, down the valley of the Souris River to a minimum altitude of about 1,410 feet.

The part of glacial Lake Souris that lies north of the International Boundary was being mapped by John A. Elson (written communication) at the time the writer was mapping south of the International Boundary. According to Elson, the lake extended about 60 miles northward and northeastward up the Souris River basin from the International Boundary and had a maximum width of 42 miles near its northeast end, near the town of Brandon. At its highest level the lake in Canada probably had an altitude of about 1,500 feet and a maximum depth of 90 feet, and in at least one place deposits more than 50 feet thick were laid down. At first, the lake was ponded along its northeast side by an ice lobe that had advanced from the north or northeast nearly to the north flank of the Turtle Mountains. As the ice melted back, Lake Souris first drained down the Pembina Trench into glacial Lake Agassiz. At this time, glacial Lake Agassiz was at its highest level and its shoreline was a few miles east of Brandon, Manitoba. Later, when the water level of glacial Lake Agassiz was lower, drainage of Lake Souris in Canada was through a spillway that had an initial altitude of 1,500 feet. The spillway floor was incised rapidly to a level of 1,485 feet and then, more slowly, to an altitude of 1,475 feet. When the 1,475 -foot level was reached, the northern part of Lake Souris, in Canada, was separated from the southern part, in North Dakota, by a strip of land 10-12 miles wide on the Canadian side, which was cut only by the spillway through which the greatly reduced southern part was still draining. At the International Boundary the spillway was about 1 mile wide, and from there southward the lake fanned out to a maximum 25-mile width on an east-west line about through the town of Upham. Southward from Upham the lake narrowed, terminating near Towner.

Little evidence has been found that would help to determine the amount of isostatic rebound since the last ice melted from the area. Johnston (1946, p. 12-17) found that the highest Herman beach of glacial Lake Agassiz, between the south end of the lake and the International Boundary, recorded a total uplift of 200 feet toward the north, or about 1.6 feet per mile. A similar study of the glacial Lake Souris area has been prevented by the absence of defined strandlines or beaches. Moreover, when the southern part of Lake Souris was in existence, the northern part was covered by ice; and then later, when the northern part was in existence, water no longer stood at its highest level in the southern part.

With a history such as that outlined above, it does not seem likely that the Souris River area could have undergone a rebound as great at 200 feet. In addition, the ice of the last glaciation probably was not as thick in the Souris River area as in the glacial Lake Agassiz area; this is indicated by the fact that the main ice sheet of the Mankato substage in the Souris River area was just able to override the top of the Coteau du Missouri to the vicinity of the Missouri River, whereas the Mankato ice in the vicinity of glacial Lake Agassiz extended much farther south. The highest point on the Max moraine, south of the glacial Lake Souris area, is about 2,300 feet; hence, because the altitude in much of the glacial Lake Souris area is about 1,500 feet, more than 800 feet of Mankato ice covered that area, if the ice advanced southward across the area. Inasmuch as the ice probably had to be more than 200 feet thick on the Coteau du Missouri to be plastic enough to flow, a total thickness of more than 1,000 feet of ice is indicated for the glacial Lake Souris area at the time of maximum advance of the Mankato substage.

Sand that is thought to have been deposited in glacial Lake Souris rims a kame (Buffalo Lodge Butte) to a height about 5 feet above the supposed maximum level of the lake. This incompatibility could be explained by isostatic rebound. On the other hand, such a small difference in elevation might be caused by ice crowding the shore, or by storms producing waves sufficiently high to deposit the sand 5 feet above the lake level. 


\section{HISTORY OF RECENT DEPOSITS}

Postglacial deposits have as yet been little changed by weathering and erosion processes, though wind, water, and gravity are beginning to make local modifications. Integrated drainage has only been established adjacent to the valleys of the Souris and the Des Lacs Rivers. Dissection is absent in most areas; many closely adjacent kettles of markedly different altitudes are unconnected by even the slightest erosion channel. Alluvium is also absent over wide areas. Soils are generally thin; many detrital lignite fragments, near the surface, are unaltered; carbonate rocks in the drift are unleached except in the upper part of the soil profile, and easily oxidized shale is commonly unaltered except at the very surface.

No sharp demarcation separates Recent from Pleistocene time. After the last retreat of the glacier in this area, periglacial conditions gradually gave way to conditions more nearly like those existing today. Yet the time since periglacial processes were active is short and Recent deposits are neither abundant nor widespread.

Small deposits of alluvium have been deposited in most water courses, the larger deposits being laid down in the valleys of the Des Lacs and Souris Rivers. However, stream gradients and volumes of water have not been sufficient to bring significant amounts of material into the area or deplete the surrounding area of much material.

Eolian processes are active today. Although some of the eolian deposits may have formed during Pleistocene time, removal of the sod cover by tillage has probably accelerated wind erosion. Also, long periods of drought periodically activate the sand dunes.

Landslides and other mass wastage processes are modifying the surface deposits. Some landslides probably formed during deglaciation, but the process has been active since then and locally is moderately active now.

\section{ECONOMIC GEOLOGY} LIGNITE

In $1950,3,260,973$ tons of lignite (Bureau of Mines, 1951 , p. 369) was mined in North Dakota. Of this, 577,515 tons was produced in the Souris River area, which-except for the eastern part-lies in the Fort Union coal region; all came from Ward County. Of six mines in operation, four were strip mines and two were underground.

Natural exposures of lignite are rare. A few poorly exposed beds crop out along the valleys of the Des Lacs and Souris Rivers and their tributaries. Artificial exposures, although fairly numerous in underground mines prior to about 1938 , exist now only in two strip mines south of Velva, and therefore the writer was able to examine only a few lignite sections. Additional information on individual mines is presented by Andrews (1939, p. 43-84), who worked in the area when most of the underground mines were accessible.

The lignite beds are from a few inches to more than 14 feet thick and are mostly of good quality. Lignite that is in direct contact with the drift is locally slacked and is of inferior quality. Most of the thicker beds extend several miles and some extend several tens of miles. The thinner beds, in contrast, commonly pinch out in short distances.

The maximum known dip of beds, other than local dips, is in the vicinity of the large Truax Traer strip mine, south of Velva in the southeast part of Ward County, where the bed dips about one degree northeast.

Factors that make mapping of lignite very difficult and estimation of reserves susceptible to large error's are sparsity of exposures, a general thinness of beds, a lack of lateral continuity of the beds, a general thick covering of glacial deposits, and the presence of buried channels where the lignite has been removed by erosion. In general, it is not possible to extrapolate with any degree of accuracy more than one-half mile away from any one exposure. For this reason, few beds are shown on the map as extending far from known outcrops, and beds generally have not been correlated, except the Coteau bed. In general, the lateral extent of the indicated and inferred position of the beds indicated on plate 1 is considerably less than that shown by Andrews (1939, map).

Lignite mining was started in the area in about 1900 , when several underground mines were opened in the valley of the Des Lacs River near Kenmare, in northern Ward County. Underground mining later spread to other parts of the area. About 1930, strip mining was started in a few places; by 1946 it was nearly the only method of operation.

In 1934, D. A. Andrews mapped the lignite in the southern part of Ward and McHenry Counties and the northern part of McLean County. These areas are included in the present report, which also gives additional data on lignite mines not started at the time of Andrews' mapping and gives a revised interpretation of the position and continuity of some lignite beds. A part of the lignite-bearing area was described by Wilder and Wood (1902, p. 74-141). Leonard, Babcock, and Dove (1925, p. 3) briefly described the lignite deposits in Ward County and made some estimates on reserves.

Total reserves of lignite in the Souris River area are estimated at $9,762.5$ million short tons. Brant 
(1953, p. 16-25, 60-74) calculated the lignite resources of North Dakota on a township basis and reference is made to his publication for an estimate of reserves in the Souris River area. The writer made considerable data available to Brant for making the estimate of reserves. In turn the writer used his estimates for calculating reserves in the Souris River area. Where a boundary of the mapped area, which was mapped mostly on a quadrangle basis, cuts across a township, the writer estimated what proportion of the reserves of that township should be included in the mapped area. On this basis the total reserves have been subdirided as follows:

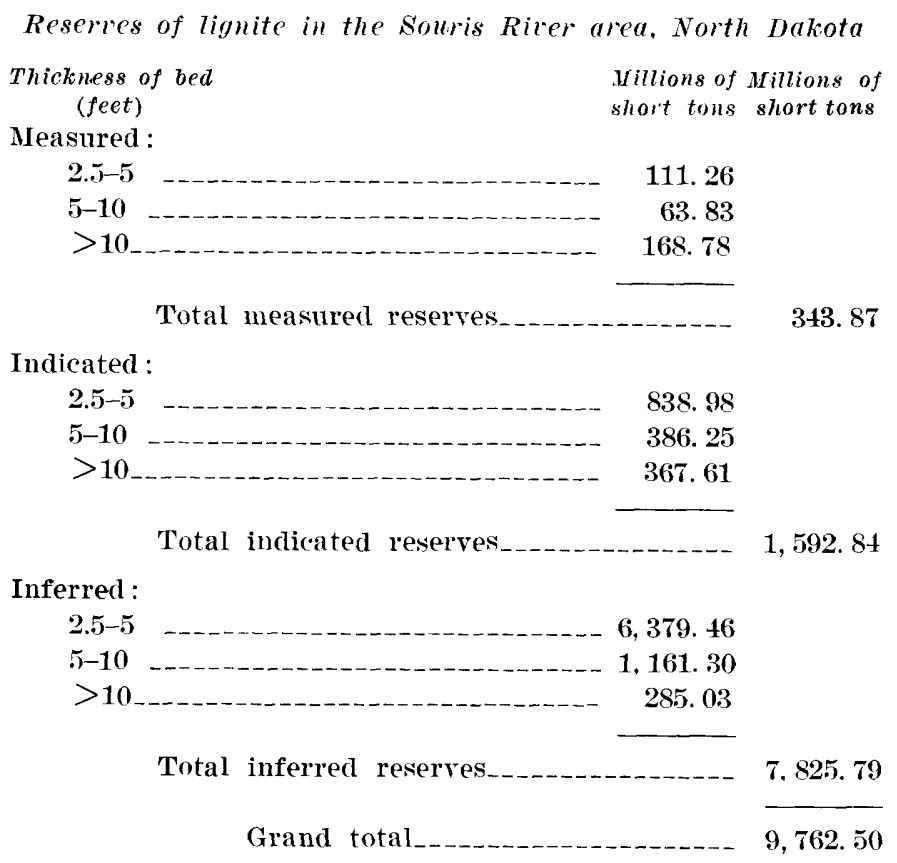

New uses for lignite and improved methods of storage and transportation will serve as an impetus to the industry. The use of lignite in thermal plants for the production of electric power is a promising field. The Rural Electrification Administration has such a plant in operation near Velva in McHenry County. Additional similar power plants, some perhaps for new industries in the area, seem likely in the future. New technological advances in the production of synthetic gaseous and liquid fuels from lignite, still largely in the experimental stages, afford promise of new markets in the future. Other hydrocarbons such as tars and waxes, produced as a byproduct in the synthesis of the fuels, hold promise for additional uses.

Because of the difficulties of correlating lignite beds and because the lignite-bearing areas do not fall into any well-defined geographic areas or fields, the lignite is described in this report by counties, starting in the northwest part of the area and proceeding southeastward. Plate 1 shows the relation of the counties to the area mapped.

\section{BURKE COUNTY}

No lignite beds are exposed in the mapped part of Burke County. However, the presence of a few abandoned mines and the reported penetration of lignite in numerous water wells indicate that several beds underlie parts of the area west of the Des Lacs River. No lignite is known to underlie the surface east of the river, although Fort Union sediments underlie glacial deposits in that area.

Except for a few insignificant workings, mining has been confined to strip pit operations in the $\mathrm{SE} 1 / 4$ sec. 36 , T. 162 N., R. 90 W. Work was carried on from about 1935 until 1942 . Near the northern end of the pit, a lignite bed reportedly 7 feet thick underlies 25 feet of overburden. Toward the southern end of the pit, the overburden is less but the lignite is reportedly thinner and more slacked. It is reported that operations at the mine were suspended because the lignite was not of quality comparable to that being mined in the Columbus-Noonan area to the west.

The lignite bed exposed by the strip mine is at an altitude of about 1,925 feet. Water-well data indicate that the bed may underlie an area several miles long, at depths of less than 50 feet, to the west and east of the mine. Plate 2 shows the extent of bedrock above an altitude of 1,925 feet in the area where the lignite bed is probably present.

Water-well logs and other data indicate that other lignite beds underlie much of the ground-moraine plain west of the Des Lacs River. A bed, reported to be 7 feet thick, was exposed in a small strip pit in the NW1/4 sec. 9, T. 161 N., R. 91 W., at an altitude of about 1,975 feet. The top of the bed is about 10 feet below the surface at the pit, but a short distance to the south it underlies the surface at considerable depth. A small strip mine just west of the mapped area, in the NW1/4 sec. 5, T. 161 N., R. 91 W., reportedly exposed 5 feet of lignite within a few feet of the surface at an altitude of about 1,965 feet. If this is the same bed as the one that was exposed in the strip pit to the east, it dips northwest about 10 feet per mile. In water wells in the area between Coteau and Woburn, 7-9 feet of lignite was reportedly penetrated at altitudes between 1,900 and 1,930 feet. This may be the same bed as in the strip mine northwest of Bowbells.

If any beds exist northwest of Flaxton, they are probably deeply buried. Near Northgate, lignite re- 
portedly underlies the surface at a depth of 90 feet. A bed reportedly 8-14 feet thick was mined in the Harrington mine in the NW1/4 sec. 27, T. 163 N., R. 88 W., at a depth of 100 feet (altitude approximately 1,740 feet). This may be the same bed as one mined to the south along the valley walls of the Des Lacs River in the northern part of Ward County.

A lignite bed 5 feet thick was penetrated in drilling the city water well of Bowbells at an altitude of about 1,925 feet; this is probably the same bed as was mined in the strip pit 2 miles to the west. Other beds were penetrated in the well at altitudes of approximately 1,880 feet, 1,835 feet, and 1,525 feet. In a well $1 \frac{1}{2}$ miles south of Bowbells, lignite was reportedly penetrated at a depth of 97 feet. This bed, however, appears to have been removed by erosion about 5 miles east of town where a well 283 feet deep was bottomed in glacial drift, according to the driller.

Little data on lignite is available for that part of the County covered by the Max moraine. The presence of a small abandoned mine on the northeast escarpment of the Max moraine, in the $\mathrm{NW}^{1} / 4$ sec. 27 , T. 161 N., R. 91 W., and of float lignite on the slope indicate that a lignite bed is at an altitude of about 2,250 feet, or within about 100 feet of the top of the moraine. If the bed continues to the south, it might be cut out in sereral places because the drift in much of this area is believed to be more than 100 feet thick. It is possible that one or more lignite beds northeast of the escarpment may also underlie part or all of the Max moraine, but at depths probably in excess of 300 feet.

Owing to the absence of exposures and because lignite beds are found at several different altitudes, it is difficult to estimate reserves in the County. A large buried channel without surface expression is believed to trend eastward across the upper half of the County and is believed to be incised as much as 200 feet into the bedrock. If so, this channel has cut out some of the lignite beds. There may also be some faults and folds in the bedrock, along the line separating the ground-moraine plain from the Max moraine, which would make correlation of beds difficult.

\section{MOUNTRAIL COUNTY}

Only a narrow strip of the northeast part of Mountrail County lies within the mapped area. Except for about 10 square miles covered with ground moraine, thick deposits of the Max moraine everywhere else form the surface of this strip. No lignite beds are exposed but numerous abandoned mines along the valley walls of the Des Lacs River in Ward County, 1-3 miles from the northeast corner of Mountrail
County, indicate that one or more lignite beds, 1-3 feet thick, probably underlie the mapped part of Mountrail County at altitudes between 1,775 and 1,850 feet. However, except for the 10 square miles covered by ground moraine, any lignite beds in the remainder of the strip probably underlie the surface at depths in excess of 150 feet.

\section{WARD COUNTY}

There are many abandoned mines in Ward County. By 1950, however, there were only four strip mines and two underground mines in operation. These operations constituted the only active mining in the mapped area in 1950 . The few exposures of lignite beds are confined mostly to the valley walls of the Des Lacs and Souris River valley walls and their tributaries.

Mining started about 1900 in the northern part of Ward County in the vicinity of Kenmare. By 1902 there were 12 openings, but between 1902 and 1920 many mines were opened along the Des Lacs River valley. Mining continued intermittently thereafter, and by 1950 there were about 165 mine openings along the valley walls of the Des Lacs River for a distance of about 5 miles upstream and 8 miles downstream from Kenmare ( $\mathrm{pl.16}$ ). The mines were chiefly slopeentry mines less than 2,000 feet long, though shaft and open-pit methods were used in a few places. Most of these mines are now caved and inaccessible. In 1950 only the John Bar mine, in the NE $1 / 4$ sec. 12 , T. 160 N., R. $89 \mathrm{~W}$., was in operation in the northern part of the County; it produced 2,200 tons that year (Easton 1950, p. 14).

The names of the mines shown in plate 16 were obtained from early lignite publications, newspapers, and oral reports. Where mines are closely spaced, one mine symbol represents more than one opening on plates 1 and 16.

Almost all the workings in the vicinity of Kenmare are confined to two beds that are poorly exposed here and there along the river-valley walls. The lower bed, nearly at lake level, is at an altitude of about 1,785 feet. The upper bed is at an altitude of about 1,825 feet (on pl. 1 , both lignite beds are shown by one symbol because the beds are too closely spaced to be shown separately). The beds reportedly are 3-6 feet thick. Much of the lignite, which generally is overlain and underlain by thin beds of clay, has a black resinous appearance, is relatively free of partings, and appears to be of good quality.

An analysis made by Wilder and Wood (1902, p. 124 ) of the lignite from the Black Diamond mine (inactive at time of mapping), about 1 mile southeast of 
Kenmare, in the NE1/4 sec. 29 , T. 160 N., R. 88 W., shows the following constituents:

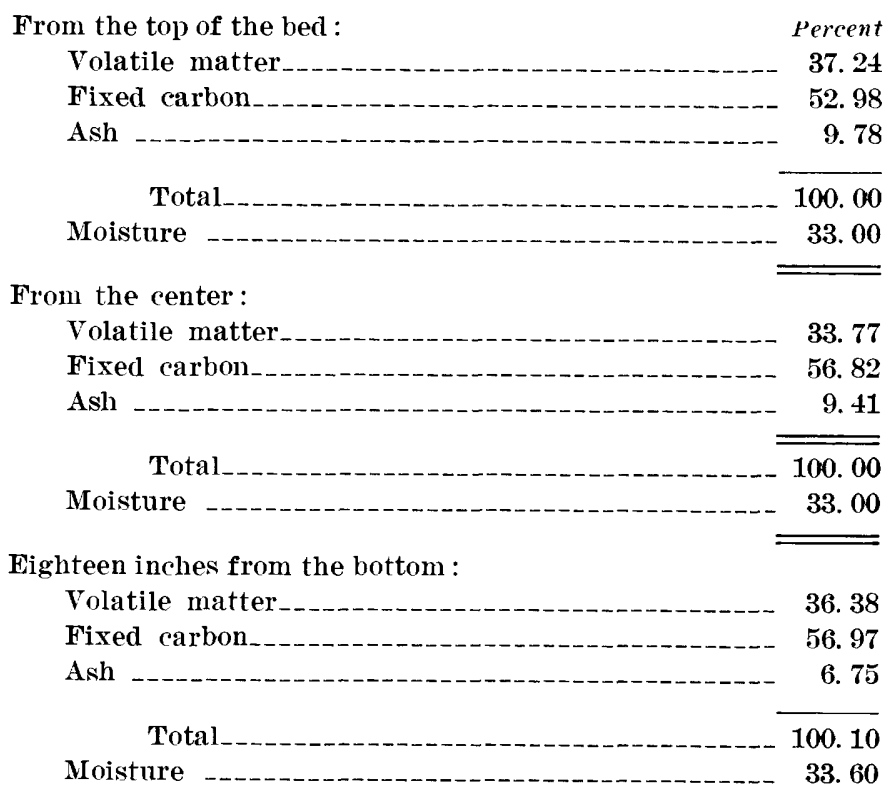

This analysis is probably fairly representative of the lignite in this area.

The great number of mine workings, mostly of unknown extent along the sides of the valley, indicates that future exploration in the vicinity of Kenmare could best be directed to the upland area. Incomplete water-well $\operatorname{logs}$ indicate that lignite underlies, at moderate depths, much of the ground-moraine plain between the valley of the Des Lacs River and the Max moraine. One mile north of Kenaston, lignite is reported at a depth of 78 feet and an altitude of about 1,950 feet. Two miles north of Kenaston, a water well is reported to have intersected a lignite bed at a depth of 97 feet and an altitude of about 1,915 feet. Lignite was reportedly mined $11 / 2$ miles south of Niobe from a bed 4-5 feet thick.

There are about 45 mine openings (not all shown on pl. 1 because of close spacing) along the valley walls of the Des Lacs River, upstream from Donnybrook for a distance of about 6 miles; most are now caved and inaccessible. In the period 1900 to 1920 , lignite was mined from two beds that were reported to be $2-4$ feet thick and to consist of brownish-black lignite, shiny and resinous in appearance and of good quality.

The portals of many of the mines in the vicinity of Donnybrook are situated in landslides. In most places, the beds are completely obscured by slumped till. Elsewhere, the beds are exposed in so few places that it has not been possible to prove their continuity between exposures. Therefore, it is not known whether the bed or beds mined are the same as the thicker beds that were mined in the vicinity of Kenmare. An outcrop in the NW1/4 sec. 31 , T. 159 N., R. 87 W., exposes lignite 1.2 feet thick at an altitude of about 1,830 feet, and a lower, extensively mined bed 2.8 feet thick at an altitude of about 1,785 feet. Possibly the same beds were mined upstream. The lower bed is fairly woody and contains some silicified wood. It is overlain by silty sand and underlain by carbonaceous shale, which, in turn, is underlain by massive sandstone. The upper bed is of fairly good quality and is overlain and underlain by clayey shale. However, the thinness of the bed, the uncertainty of its continuity, and the unknown extent of the mine workings do not appear to favor large-scale mining in this segment of the valley.

In sec. 5, T. 158 N., R. 87 W., a 4 -foot bed of lignite in the Leigh and Ericson mine was described by Wilder and Wood $(1902$, p. 121-122) as overlain by 1 foot of clay and underlain by clay to the bottom of the mine. Analysis showed that the lignite contained 35.14 percent volatile matter, 59.75 percent fixed carbon, and 5.11 percent ash.

There are about 15 inactive and inaccessible mines within $1 \frac{1}{2}$ miles of Carpio. The lignite appears to have been mined from one or more beds at an altitude of about 1,745 feet; but all the mines are now inactive and inaccessible, and lignite is nowhere exposed. The lignite is reportedly $2.5-3$ feet thick and of good quality. A section measured by Andrews $(1939$, p. 69$)$ at a mine 1 mile southeast of Carpio shows 2 feet 9 inches of lignite underlain by 6 inches of clay which, in turn, is underlain by 1 foot 7 inches of lignite.

No mining has been done from a point about one mile southeast of Carpio to Foxholm. Andrews (1939, p. 68) believes that between these two points the lignite dips a few feet below the level of the alluvium. However, the writer believes that the bed mined at Carpio is a higher and different bed than one mined downstream from Foxholm.

There are about 80 inactive mines, mostly inaccessible, between Foxholm and Minot. The mines are confined to the valley walls of the Des Lacs River, the Souris River below its confluence with the Des Lacs River, and the tributaries of these streams.

As indicated from workings and from a few poor exposures of lignite, mining between Foxholm and Minot was carried on, at altitudes of 1,600-1,675 feet, from 3 or more beds. Of these beds, the Burlington bed described by Andrews (1939, p. 68) was mined most extensively. It is reported to be 7-10 feet thick and to be divided by several clay seams. A section, measured by Andrews (1939, p. 69) in the NW1/4 sec. 5, T. $155 \mathrm{~N}$., R. $84 \mathrm{~W}$., shows that a bed of lignite 1 foot 6 inches thick was underlain successively by clay, 2 inches; lig- 
nite, 1 foot 6 inches; clay, 2 inches; lignite, 4 feet 6 inches; clay, 1 foot 6 inches; and lignite, 3 feet. The lignite mined at the old Carlson mine, about one-third mile south of Foxholm, is reportedly 8-9 feet thick and of excellent quality, except for a clay parting 1 foot thick near the middle of the bed. About 1944, the Truax-Traer Coal Co. did some test drilling in several places near this mine but reportedly found no lignite. Whether the lignite had been removed by erosion or mined out is not known.

From Burlington downstream, most if not all of the mining appears to have been from the Burlington bed, at an altitude of about 1,620 feet or slightly less. The bed in this area is reported to be $8-10$ feet thick. One or two clay seams, generally 2 inches or less thick, occur commonly near the bottom of the lignite section (see lignite secs. 10, 11, 12, 13, 14, and 17 by Andrews, 1939, p. 69). Several mines were in operation until at least 1925. Among these was the Midway Coal Co. mine in the SE $1 / 4$ sec. 33, T. 156 N., R. 84 W.; the Burlington mine (Stearns? mine) in the SE1/4 sec. 2, T. 155 N., R. $84 \mathrm{~W}$.; the Larsen mine in sec. 3, T. 155 N., R. 84 W.; the Colton mine in the SE $1 / 4$ sec. 1 , T. 155 N., R. 84 W., and the Hunnerwell mine in the NE $1 / 4$ sec. 1, T. $155 \mathrm{~N}$., R. 84 W. Wilder and Wood (1902, p. 113) made the following analysis from different parts of the bed: Volatile matter, 35.83 percent; fixed carbon, 51.58 percent; and ash, 11.88 percent. The average amount of moisture was 32 percent. Another bed, 3 feet thick, is reported below the mined bed.

A lignite section measured by Andrews (1939, p. 69) in the NE1/4 sec. 19, T. 155 N., R. 83 W., shows 4 feet 8 inches of lignite underlain by as much as 5 inches of clay, which, in turn, is underlain by more than 3 feet of bony lignite. Another lignite bed measured by Andrews, presumably in a strip mine in the SE1/4 sec. $19, \mathrm{~T}$. 155 N., R. $83 \mathrm{~W}$., shows 2 feet 5 inches of lignite underlain by one-half inch of clay, which, in turn, is underlain by 3 feet of bony lignite. Wilder (1902, p. 119) measured the following beds of lignite in the New Era mine in sec. 15, T. 155 N., R. 84 W.: a 5 -foot bed at a depth of 184 feet; a 6 -inch bed at 199 feet 6 inches; an 18-inch bed at 216 feet; and one of 11 feet 9 inches at 254 feet. This mine could not be found by the writer. A thin bed at an altitude of about 1,675 feet was mined in an open pit and a small adit in South Branch Coulee, 6 miles southwest of Minot.

All mining southeast of Minot in Ward County-except a small inactive mine in the $\mathrm{SE} 1 / 4$ sec. $33, \mathrm{~T} .155 \mathrm{~N}$., R. $82 \mathrm{~W}$., in which a bed 2-3 feet thick was workedhas been in the Coteau bed, as described by Andrews $(1939$, p. 71-72). The Coteau bed (pl. 1) underlies, in most places, a strip of ground-moraine plain one-half to more than 2 miles wide, adjacent and parallel to the Max moraine. It is not known whether it also underlies in the Max moraine. In 1950, lignite was obtained from this bed in 5 of the 6 active mines in the County.

The Coteau bed is poorly exposed in a few tributaries near the Max moraine. Elsewhere it underlies the ground-moraine plain at depths generally in excess of 50 feet. The bed in most places in the County ranges in thickness from 12 to 16 feet and averages about 14 feet.

The lignite in the Coteau bed is hard and is generally of good quality where it is separated from the till by a few feet of shale or sand. Where it is in direct contact with till, it is hard in some places but soft and considerably oxidized in other places. Presumably, in the places where the lignite had been exposed at the surface for a considerable period of time before being buried by drift it became oxidized and soft.

The northwesternmost mine in operation in 1950 on the Coteau bed was the Miller Mine (operated by Alfred Martin) in the N1/2 sec. 11, T. 152 N., R. $82 \mathrm{~W}$. According to Easton (1950, p. 14), production from this mine in 1950 was $40,036+$ tons. Lignite was mined by stripping off the overburden along the bottom of Oak Creek. In 1949 stripping was proceeding upstream to the southwest, and 14 feet of good-quality lignite was exposed. Elsewhere in the pit, the lignite was reported to range in thickness from 12 to 14 feet. A one-half inch clay seam was present one foot from the bottom. In most places, the top of the lignite is in direct contact with till, but elsewhere, a few feet of gray fine-grained moderately consolidated. clayey sandstone separates the lignite from the till. Some minor structure is indicated. The lignite appears to dip downstream or to the northeast 15-20 feet in one-half mile, in a slope about equal to the gradient of the stream. Small folds or "rolls" that strike about S. $65^{\circ} \mathrm{E}$. and have closures of 3 feet or less are common along the upper contact. In 1949, the maximum overburden being removed was 55 feet. However, if stripping is continued into the upland on one or both sides of the creek, 80-85 feet of overburden will have to be removed. A moderate amount of water enters the mine from the west along the bed, which necessitates some pumping. The lignite is screened at the mine into lump, nut, and stoker size. The overburden is stripped by carryall and bulldozer. The lignite is removed by mechanical shovel. Mining started in this area many years ago, and the workings were first called the Turtle Gulch mine. About 30,000 tons of lignite is reported to have been mined from this operation in 1948 . 
Two other mines near the Miller mine were once fairly extensive. These mines are the Walker mine and the Bigley or Mammoth Spring mine, both in the $\mathrm{S} 1 / 2$ of sec. 27, T. 153 N., R. 82 W. The Walker mine was inactive by 1925 and the Bigley mine was abandoned sometime later. The Coteau bed is reported to be as much as 14 feet thick in this area. Andrews (1939, pl. 14) shows the following thicknesses in his section 19 of the bed at this locality: lignite, 6 inches; clay, $1 / 2$ inch; lignite, 8 feet 5 inches; and bony lignite, 3 feet. The bed appears to dip northeast, or downstream; the lignite in the Walker nine is 10-15 feet higher than in the Bigley mine, or at an altitude of about 1,810 feet.

In 1950 there were 4 active mines on the Coteau bed about 8 miles south of Sawyer in T. 152 N. and Rs. 81 and $82 \mathrm{~W}$. Of these the Traux-Traer, Quality Lignite, and West Side mines were strip mines, and the Vix mine, an underground mine.

The Truax-Traer strip mine covers parts of 3 sections of land in T. 152 N., R. 81 W. Mining in 1949 was confined to the eastern end of the pit, where about 50 feet of overburden was being removed. To the west, as much as 70 feet of overburden had been removed. The lignite bed averages about 14 feet thick. In most places, a clay seam a few inches to $11 / 2$ feet thick divides the bed about 4 feet from the bottom. In general, the lignite is hard and of good quality. However, near the eastern edge of the pit, as exposed in 1949, the lignite was in direct contact with the drift and locally was dry and partly slaked.

According to Easton $(1950$, p. 14), 432,516 + tons of lignite was mined in 1950 in the Truax-Traer strip mine. This is more than 75 percent of the total production in the mapped area. The first 40-50 feet of overburden was stripped by means of a tower-excavator type of shovel, which has a capacity of about 14 cubic yards. A second shovel, of standard design, removes the remainder of the overburden, and a third shovel removes the lignite. The lignite is dumped into large trucks and hauled to the tipple, where it is screened and loaded into freight cars or trucks.

The second largest operation in 1950 was the Quality Lignite mine, in sec. 19 , 'T. 152 N., R. 81 W., and sec. 24 , T. 152 N., R. 82 W. According to Easton (1950, p. 14), 70,181 tons of lignite was produced in 1950. About 12 feet of lignite was exposed. At the site of operations, the lignite was fairly dry and slaked rather readily. There was 65-80 feet of overburden. About 12 feet of clayey sand of the Tongue River nember of the Fort Union formation separated the lignite from the overlying glacial drift. A maximum of about 1,000 tons of lignite was being mined daily. It is reported that $50,000-60,000$ tons was mined in 1948 .
Mining was started at the West Side strip mine, in the SE1/4 sec. 23, T. 152 N., R. 82 W., in the fall of 1949. According to Easton (1950, p. 14), 7,299 tons of lignite was produced in 1950 . Twenty to thirty feet of overburden was being removed along the creek bottom. Lignite was not exposed but it was reported to be 12 feet thick, hard and of good quality. An additional 3 feet of lignite, separated by a thin seam of clay a few inches thick, underlies the main bed. The Bechtold shaft mine, a few hundred feet southwest of the West Side strip mine and about 100 feet deep, was in operation until late 1949. Both mines were operated by C. P. Bechtold. A bed of lignite 12-14 feet thick was being mined in 1949.

Vix mine is in the NW1/4 sec. 25 , T. 152 N., R. 82 W. Its entry is a downward-inclined adit that intersects the lignite 20-30 feet below the alluvial surface of the tributary on which the mine is located. The lignite being mined was reportedly 14 feet thick. Some structure is indicated; the bed is said to "roll" and dip to the northeast. According to Easton (1950, p. 14), 4,870 tons of lignite was mined in 1950 .

More dip and faults are indicated in the Coteau bed in T. 152 N., Rs. 81 and 82 W., than elsewhere in the mapped area, even though there are few exposures. In that area, the Coteau bed dips to the northeast, from an altitude of about 1,930 feet about 1 mile from the escarpment to an altitude of less than 1,800 feet about 3 miles to the northeast. This dip, although only 65 feet per mile, may permit a considerable amount of the bed to be recoverable by strip mining, inasmuch as the dip is only slightly less than the surface slope, and both are in the same direction.

Fairly numerous local folds and minor faults are indicated in the Coteau bed, and a number of them have controlled the trends of some secondary tributaries. This type of structure is strongly indicated in secs. 19 and 20 , T. 152 N., R. 81 W., and sec. 24 , T. 152 N., R. $82 \mathrm{~W}$., where many streams follow small faults or steepwalled narrow synclines. Small faults that trend northwest are reported in the mine workings. Other small faults or synclines are indicated to trend approximately at right angles to these. In the $\mathrm{NE} 1 / 4$ sec. 24 , T. 152 N., R. 82 W., where it has an apparent dip to the west, the Coteau bed is exposed at an altitude of about 1,840 feet. About 500 feet to the southeast and on the opposite side of the tributary, the bed is exposed at an altitude of about 1,810 feet although the regional dip is to the northeast. Similar structure is indicated elsewhere, but little confirmatory work has been done because exposures are few.

Most of the future mining in the county probably will be in the Coteau bed, which appears to offer the 
best possibility for stripping. A considerable area between the present mines on the bed and the Max moraine might be feasible for stripping, inasmuch as the northeastward sloping upland is nearly paralleled by the lignite bed, which generally lies at a depth of less than 100 feet. This area, however, should be systematically drilled to ascertain the presence of local flexures that alter the depth to the lignite, and also to locate buried valleys where the lignite has been removed by erosion. Likewise, the lignite should be cored in advance of mining to determine its quality, especially where it is in direct contact with the overlying drift.

Lignite-bearing strata of the Fort Union underlie all of the ground-moraine plain in Ward County except possibly the extreme northeast corner, where the marine Cannonball member of the Fort Union formation might be in contact with surficial deposits. Lignite beds have been penetrated in many wells dug through the ground moraine in the area on both sides of the valleys of the Souris and Des Lacs Rivers. In most of these places, however, the lignite beds are present at depths of 100-200 feet and probably could not be mined by present-day stripping methods.

Lignite beds probably underlie most, if not all, of the Max moraine in the county, but at depths generally in excess of 200 feet.

\section{RENVILLE COUNTY}

There are about 27 small abandoned mine openings along the valley walls of the Des Lacs River in the southwest corner of Renville County. No lignite beds are exposed, but it is likely that mining was on the same bed or beds that were mined upstream near Donnybrook, in Ward County. If so, the bed or beds are probably 2-3 feet thick and the lignite is of good quality.

The only known lignite mined northeast of the Des Lacs River valley in the county is from the abandoned Matson mine about 2 miles west of Tolley. Here, 12 feet of lignite, containing a clay parting 1 foot thick, reportedly was mined at a depth of 280 feet at an altitude of about 1,550 feet.

All of the upland away from the valleys of the Des Lacs and Souris Rivers is underlain by till that is believed to be more than 200 feet thick in most places. Meager water-well data indicate that lignite may underlie the till in a few places. However, because it lies at great depth and because the eastern and northeastern part of the county is underlain by only the basal part of the lignite-bearing Fort Union formation, there appears little possibility that lignite in commercial quantities will be found beneath the upland.

\section{BOTTINEAU COUNTY}

There are no lignite mines or exposures of lignite in Bottineau County within the mapped area. The entire surface is mantled with surficial deposits, generally more than 150 feet thick. Along the western edge and southwestern corner of the county, lignite is reported to have been penetrated in several water wells at depths generally in excess of 175 feet. The lignite beds are probably near the base of the Tongue River member of the Fort Union formation. These strata have been removed by erosion in the eastern part of the county that lies within the mapped area, and marine strata form the uppermost bedrock. It seems unlikely that lignite in commercial quantities will be mined.

\section{MOHENRY COUNTY}

Mining has been restricted to a few small strip mines in the southwest corner of McHenry County. All mining has been confined to the Coteau bed, which is close to the surface in the bottom of several small tributaries that head in the Max moraine. The lignite is reported to be considerably thinner than on the same bed in the southeast corner of Ward County. In most places, the bed averages about 5 feet in thickness and contains one or more clay seams. (See lignite sections by Andrews, 1939, pl. 14.) The lignite appears to dip to the northeast. Exposures range in altitude from about 1,860 feet to 1,830 feet.

Only a band less than one-half mile wide along the northeast edge of the Max moraine escarpment offers any possibilities for stripping. Moreover, lignite has not been found in a considerable segment of this band and may have been removed by erosion. The Coteau bed probably underlies much of the Max moraine in the southwest corner of the county but at depths, in most places, in excess of 200 feet. Lignite probably is absent in the eastern and northern one-third of the county, where much of the area is inderlain by marine sediments of the Cannonball member.

Thin seams of lignite have been intersected in water wells both north and south of Velva. However, inasmuch as no thick sections of lignite are near the surface and because the lignite-bearing strata of the Fort Union formation in that area are mostly removed and are underlain by marine sediments, there appears little possibility that lignite in commercial quantities will be found in the county other than possibly in the vicinity of Kongsberg.

\section{MCLEAN COUNTY}

Only the northeast corner of McLean County is within the mapped area. Most of this part of the county is covered by deposits of the Max moraine, 


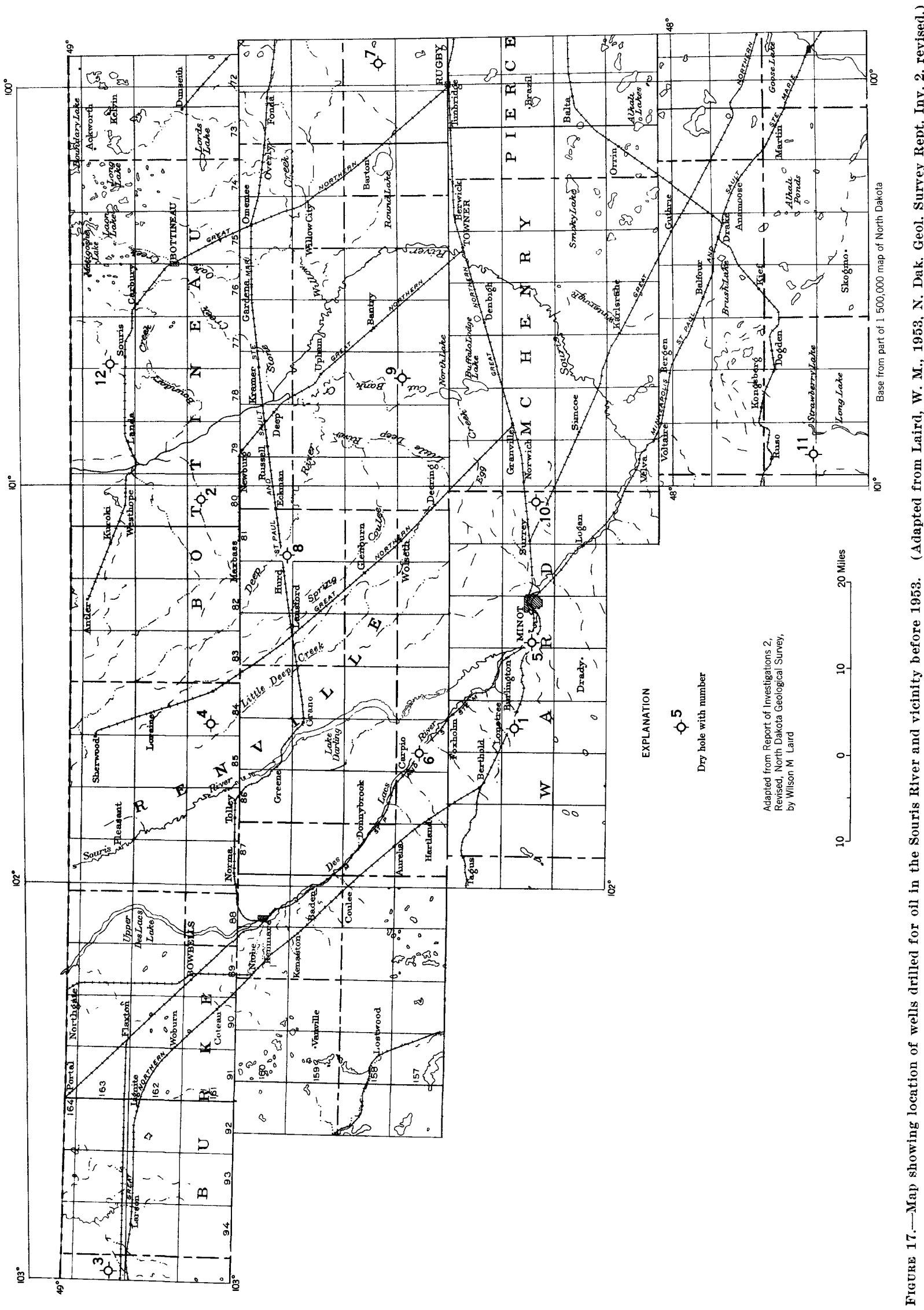




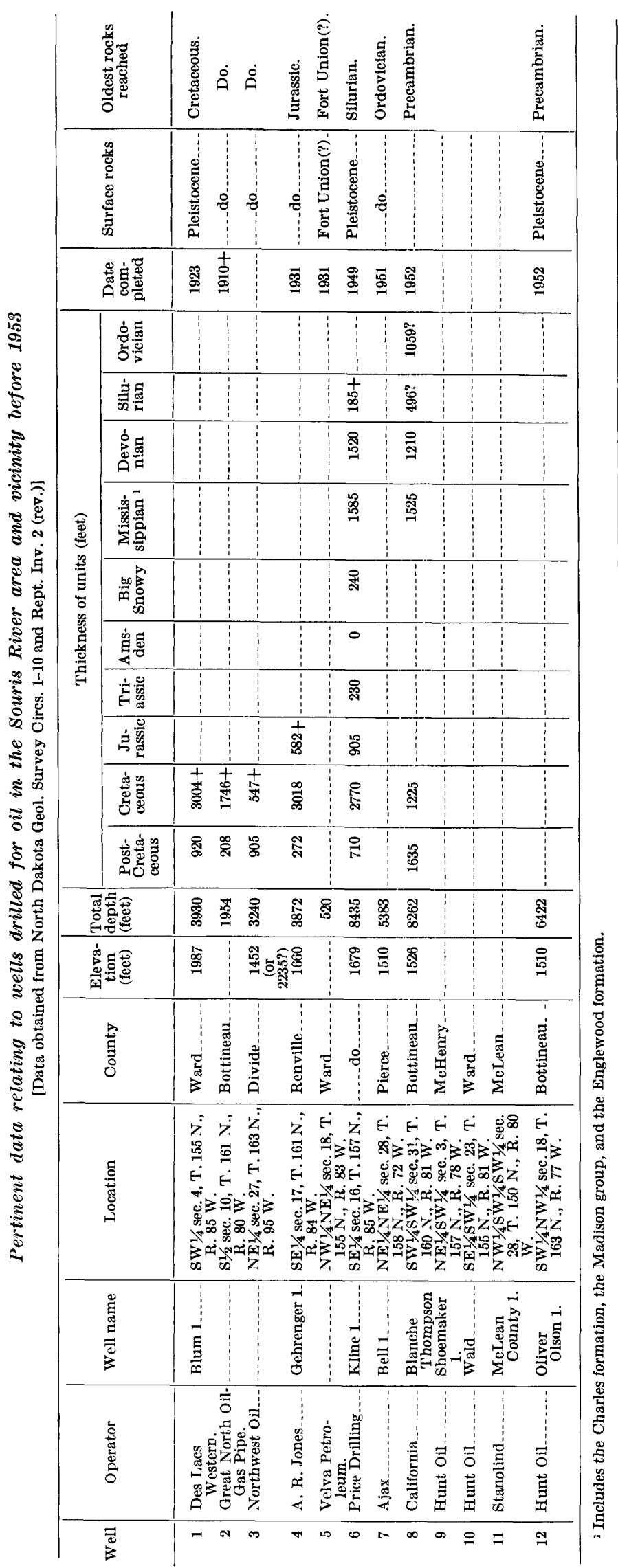

which are probably more than 150 feet thick in most places.

Six small, abandoned strip and adit mines, which worked the Coteau bed, are along the northeast escarpment of the Max moraine. The lignite is reported to be $5-7$ feet thick and to contain one or more clay seams. Few possibilities exist for stripping because the northeast limits of the Coteau bed appear nearly to coincide with the northeast escarpment of the Max moraine. Therefore, nearly all the reserves probably underlie the Max moraine at depths in excess of 150 feet. No other beds are known to occur in the mapped part of the county.

\section{SHERIDAN COUNTY}

Only about 27 square miles of the northwest corner of Sheridan County is within the mapped area. No lignite beds are known to occur in this part of the county. The lignite-bearing strata in the area are mostly removed by erosion and are underlain by marine sediments. Therefore, there appears little possibility that any commercial lignite will be found.

\section{PETROLEUM}

Petroleum was first discovered in North Dakota in January 1951. At that time, the Amerada Petroleum Corporation drilled the Clarence Iverson well 1 on the Nesson anticline in Williams County, about 75 miles west of Minot. The formations penetrated in the well are described by Laird (1952a, p. 13-14).

The finding of oil in the Clarence Iverson well 1 greatly increased the search for oil in adjacent areas and other parts of the State. By July 1952, there were 20 producing wells in the vicinity of the initial discovery. No oil was found outside of this area in the State until early in 1953 when oil was found in the Souris River area in a well drilled in Bottineau County, a few miles south of Westhope. The writer has no information on this well, inasmuch as it was drilled after field work had been terminated on the project. It is reported also that oil was found in late 1952 in Manitoba, a few miles north of the International Boundary, north of Westhope.

Figure 17 shows the location of wells that had been drilled for oil in the Souris River and nearby areas by the spring of 1952 . In the table following figure 17 are data relating to the wells; most of these data have been obtained from Laird (1953, sheet 1).

Information on the earlier drilled wells can be obtained from Laird's "Selected deep well records" (1941, p. 1-31), and on the wells drilled between 1948 and 1952 from several North Dakota Geological Survey Circulars by Laird (1951, p. 1-12 and 1952a, p. 1-36), 
Anderson (1952a, p. 1-11; 1952b, p. 1-13; 1953a, p. $1-15 ; 1953 b$, p. $1-17)$, and Towse ([1952], p. 1-23).

An intensive geophysical program was conducted in the Souris River area by several major oil companies between 1949 and 1953, and several new wells were drilled during 1953.

Several factors appear to favor finding more oil in the area. In addition to the one well already reported in production, oil has been found in Manitoba directly to the north of the Souris River area. As pointed out previously, the structure in the area is more complicated than previously supposed. It is possible that all or parts of the Coteau du Missouri might be high structurally as well as topographically. The northeast escarpment of the Coteau du Missouri, at least in places, may be a fault scarp. Minor folding and faulting are suggested in other parts of the area. Whether or not structure of these types extends to depth is unknown at present. Also, it is possible that sections of Paleozoic sedimentary rocks have been wedged out, giving rise to structure that is favorable for oil accumulation. The area lies toward the eastern edge of the Williston basin, where such wedgings take place, although their precise locations are still unknown. Laird (1952c, p. 8-9) has pointed out the possibility of stratigraphic traps caused by unconformities, such as the bases of the Triassic and Jurassic. Inasmuch as several wells have been completed in Manitoba in this type of geologic setting, it is possible that production similar to that in Manitoba could exist in the Souris River area.

It should be emphasized that the above assumptions are made upon very scanty evidence and should only serve as a possible guide to further exploratory work. Large tracts in the Souris River area have not undergone exploratory drilling. These tracts, as well as sites where only shallow drilling has been done, might hold promise for further exploratory work.

\section{GAS}

Minor amounts of gas, used locally on farms, have been obtained from shallow wells in the vicinity of Westhope, in northwestern Bottineau and eastern Ward Counties. Gas was first found in 1907, about $91 / 2$ miles south of Westhope at a depth of 178 feet, during drilling for water. Following this initial discovery, other discoveries were made nearby and in the vicinity of Mohall, Lansford, Maxbass, and Deering.

The gas reportedly is in a sand 16-20 feet thick, generally at depths of 150-300 feet. Although drift deposits are as much as 250 feet thick in many places in the area, probably all the gas is in bedrock. It is not clear, however. which strata are gas bearing. This is the area where Tongue River strata thin to extinction and where the underlying Cannonball member and possibly the Fox Hills sandstone are also thin. Therefore, it is not known with certainty which one of these three units carries the gas. Evidence points to the Cannonball member, inasmuch as the gas-bearing sand reportedly is greenish black and more closely resembles the color of the Cannonball sediments than any other strata.

The gas appears to be localized in a north-trending anticline of very small closure that extends from near Deering northward to the International Boundary. Only scanty evidence, based on logs of a few water wells, indicates the presence of this structure.

In 1952 no gas, either commercial or for local farm use, was being produced in the mapped area. It appears doubtful that commercial quantities of any size will be produced from shallow wells. Whether or not gas in commercial quantities will be found in deep oil wells is not known.

\section{CONSTRUCTION MATERIALS}

Some kinds of construction materials are abundant and other kinds are scarce. Sand and gravel are especially common; nearly all deposits are suited for road metal and many can be used for concrete aggregate and other purposes. On the other hand, quarry rock suitable for building purposes is lacking.

\section{SAND AND GRAVEL}

River-terrace deposits and diversion-channel deposits offer the best possibilities for commercial gravel. Ice-marginal outwash-channel deposits are the next most important source of gravel; kame and esker deposits furnish local supplies for road construction; and small reserves are present in overridden ice-contact deposits. The southern part of glacial Lake Souris, especially the dune area, contains an almost unlimited source of sand, though no use is now made of the deposits.

Sand and gravel pits in the area are shown on plate 1. Of these, only four are worked for uses other than highway construction.

One of the 4 pits, worked by the Minot Sand and Gravel Co., is about 2 miles west of Minot, in the NW $1 / 4$ sec. 21, T. 155 N., R. $83 \mathrm{~W}$. The pit is about 40 feet deep and several hundred feet long. The material ranges in coarseness from sand to boulders as much as 8 feet long; cobbles are common. In places, the material is well sorted; in other places, it is poorly sorted. Pieces of float lignite, a few weighing as much as a ton, are present. In 1948, a typical year of operation, 119,277 cubic yards of material was obtained from the 
pit. Of this, 51,735 cubic yards was structural sand, 7,865 cubic yards was paving and road gravel and the remainder had other miscellaneous uses. Cobbles and boulders have been piled or left in the bottom of the pit. Roughly, 10 carloads of cobbles and boulders are piled in the pit and 15 carloads are scattered on the bottom of the pit. Reserves of sand and gravel are very large; they include all the outwash that constitutes the terrace deposit (see pl. 1) which, in most places, is 40 feet thick.

A second pit, 21/2 miles southeast of Minot in sec. 30, T. 155 N., R. 82 W., is worked by the Minneapolis, St. Paul, and Sault Ste. Marie Railroad. The pit is nearly one-half mile long and has a maximum depth of 33 feet, though the gravel extends deeper. Most of the material is less than 4 inches in diameter and moderately well sorted. A few cobbles and boulders as much as 6 feet long are present, but, in general, the material is finer than that in the pit west of Minot. Reserves are large as indicated by the size of the terrace deposit (see pl. 1). In most places, the deposit is at least 30 feet thick and, locally, may be considerably thicker.

A pit in a diversion channel in sec. 34, T. 154 N., R. $78 \mathrm{E}$., is operated by the Great Northern Railway. The pit is three-fourths mile long, 300-500 feet wide, and 13-17 feet deep. The material is loaded by shovel directly into railroad cars on a short spur that extends down into the pit. The deposit consists chiefly of fairly clean fine gravel and sand. Huge reserves are indicated to the east and north of the pit, as shown by the areal extent of this part of the diversion channel. Part of these reserves, however, might be mostly coarse sand and, therefore, too fine for most uses.

A pit 300-400 feet long and 15 feet deep was opened in 1948 in a terrace deposit along the Souris River, in sec. 3, T. 159 N., R. 85 W., by the J. L. Shiely Company. The gravel was used in the Garrison dam in west-central North Dakota for coarse aggregrate. This is the coarsest material found anywhere in the mapped area. Much of it exceeds 4 inches in diameter and rounded cobbles as much as 10 inches in diameter are common. Screen-size analysis and other characteristics of the deposit are given under the description of riverterrace deposits in the section on "Descriptive geology." Material finer than 2 inches in diameter was screened out and not used; much of this can be used in the future for road metal. The remainder, which constitutes about one-half of the material, was crushed at the site for use as aggregate. Reportedly, the company received $\$ 1.43$ per ton for the crushed material loaded on the car at the plant. Reserves are fairly large, as shown by the areal extent of the terrace and by the fact that the deposits are 20-30 feet thick. A similar type of deposit containing much larger reserves, only slightly less coarse, is found at Greene, in sec. 30, T. 160 N., R. $85 \mathrm{~W}$. The largeness of reserves, together with the fact that the Minneapolis, St. Paul, and Saulte Ste. Marie Railroad traverses the back edge of the terrace, makes future exploitation of this deposit very likely. A few small pits, in which the material was used locally for road construction, have been excavated into the deposit.

Many other river-terrace deposits contain large reserves. Most are upstream from Minot in the ${ }^{x}$ valleys of the Souris and Des Lacs Rivers. Small pits have been dug in some for road material, but others have not been tested. In general, the river terraces contain the coarsest and thickest deposits.

The largest reserves of commercial sand and gravel in ice-marginal outwash-channel deposits are near the mouths of the larger outwash channels in the Souris River loop area. Most of the deposits consist of fine to medium gravel and sand, generally less than 15 feet thick.

Large reserves of sand and gravel are in the heads of the Velva and Verendrye diversion channels. Many small pits at the head of the Velva channel expose fine gravel and sand 20-30 feet thick. The deposits in this channel become progressively finer away from the head of the channel, so that in the vicinity of Voltaire they consist of sand. Nearly all the deposits in the Verendrye diversion channel consist of fine gravel and sand, although they are of large areal extent and are more than 15 feet thick in most places. No significant commercial deposits have been found in the Hester Lake diversion channel.

Reserves in individual kame and esker deposits are usually small; the material is poorly sorted and in places is intertongued with till. These deposits furnish material useful for local road surfacing. The largest deposits are in two large kames-one, $11 / 2$ miles northeast of Sawyer and the other, about 4 miles northeast of Granville. The deposit near Sawyer appears to be coarser than the one near Granville. Although most of the material in the deposit near Sawyer is fine to medium gravel, there are some boulders as much as 4 feet long.

Commercial reserves from the overridden ice-contact deposits are small, because of the narrow width of the outcrop. In most places, the deposits are overlain by till to a depth that discourages exploitation.

Glaciofluvial deposits, undifferentiated as to origin, provide relatively small reserves of sand and fine gravel. 


\section{RIPRAP AND BUILDING STONE}

Glacial erratics, scattered either on the surface of the Max moraine, the end moraines in the Souris loop area, on the ground moraine, or in glacial outwash deposits, are about the only source of riprap in the area. Although the boulders have a large total volume, they are so scattered in most places that to collect them would be costly. In some places, however, they are probably sufficiently concentrated to be commercial deposits.

Local concentrations of boulders on the Max moraine are commonly found in nestlike bunches on the crests or sides of knobs and ridges. Similar concentrations are found on end moraines in the southern part of the Souris River loop area. The boulders are also numerous on the ground-moraine surface along the walls of the main valleys, where they have been concentrated by erosion. They are particularly abundant along the valley walls of the Des Lacs River between Kenmare and the International Boundary but are also on the upland surface of the ground moraine. Where the land has been farmed, the boulders have been placed in piles and offer a possible source of riprap. Most piles, however, are small and collection would be costly. The boulders on both the end moraines and ground moraines are generally less than 4 feet long; more commonly, about 2 feet. Nearly all of the larger boulders are granitic, whereas some of the smaller boulders are carbonate rock.

The surfaces of some river-terrace deposits probably contain the best supply of boulders, particularly those deposits whose surfaces have been reworked by melt waters, so that the fine materials have been removed and a residuum of cobbles and boulders has been left. One such deposit is on the north side of the Souris River about 1 mile northwest of Sawyer. There, cobbles and boulders as much as 5 feet in length almost completely stud the surface. Inasmuch as the terrace is traversed almost its entire length by the Minneapolis, St. Paul, and Saulte Ste. Marie Railroad, it might be commercially feasible to collect the boulders. A similar concentration, though of much smaller extent, caps a terrace about 1 mile northwest of Verendrye. Other deposits of this type are along the valley of the Des Lacs River from Carpio downstream to its confluence with the Souris River. In places, boulders are so abundant that it is possible to walk the length of a terrace stepping from one boulder to another, although many boulders have already been removed from some terraces. Some boulders can be obtained from river-terrace deposits, where they have been discarded in sand and gravel pits. In most pits, however, the discarded boulders are too few to be of value. A possible excep- tion is the pit of the Minot Sand and Gravel Co. northwest of Minot, where roughly 25 carloads of cobbles and boulders have been piled or have been left along the bottom of the pit. Most are 2 feet long, but some attain a length of more than 6 feet.

The sandstone that crops out in tributary valleys 2-3 miles southwest of Velva has had limited local use as a building stone. Because of the calcareous cementing material of the stone, it leaches fairly easily and, therefore, is unfit for many commercial uses. Moreover, individual outcrops are generally small and scattered.

\section{TILL}

Except in the area covered by glacial Lake Souris, till is readily available in unlimited quantities. At present, almost its sole use is for the subgrade of almost all primary roads and the entire road grade for most secondary roads. It has been used to a limited extent as a surface binder for roads built in noncohesive sand in the glacial Lake Souris area. Such a use will probably have a wider application in the future. Because of its near impermeability, till could be used as an impervious lining for irrigation canals that have to be dug through more pervious deposits, such as river-terrace and icemarginal outwash-channel deposits.

\section{SODIUM SULFATE (GLAUBER SALT)}

As a result of work done by Lavine and Feinstein (1934, p. 1-8), Grossman (1949, p. 1-66), and Binyon (1951, p. 1-62), reserves of $30,439,000$ tons of Glauber salt $\left(\mathrm{Na}_{2} \mathrm{SO}_{4}\right)$ were found in 21 deposits in northwestern North Dakota. Most of these reserves are in southwestern Divide County and northwestern Williams County, where they are found in chains of lakes that occur in sinuous depressions in the glacial drift. The sodium sulfate occurs as brine in the lake water, as crystals, and in beds at the bottom of the lakes.

The only lake in the Souris River area that appeared to the writer to be worthy of testing for the salts was Carpenter Lake, Ward County, in sec. 18, T. 155 N., R. 78 W. Tests made by Binyon (1952, p. 28) at Carpenter Lake show that a sample of brine obtained 2.8 feet below the surface of the lake contained the following percents of salts: $0.10 \mathrm{NaCl}, 0.10 \mathrm{Na}_{2} \mathrm{CO}_{3}, 0.33$ $\mathrm{NaHCO}_{3}, 0.04 \mathrm{CaSO}_{4}, 0.08 \mathrm{KHCO}_{3}, 0.15 \mathrm{MgSO}_{4}, 0.95$ water insolubles, 95.53 total $\mathrm{H}_{2} \mathrm{O}$, and $2.72 \mathrm{Na}_{2} \mathrm{SO}_{4}$. The content of $\mathrm{Na}_{2} \mathrm{SO}_{4}$ as Glauber salt $\left(\mathrm{Na}_{2} \mathrm{SO}_{4} \cdot 10 \mathrm{H}_{2} \mathrm{O}\right)$ was 6.17 percent and of free $\mathrm{H}_{2} \mathrm{O}$ was 92.08 percent. The lake bottom contains less than 4 percent of Glauber salt. Binyon estimated the area of Carpenter Lake to be $18,300,000$ square feet, its average depth 2.8 feet; at a tonnage factor (cu feet per ton) of 32 , the weight of the brine was about 1,600,000 short tons; and as the Glauber salt content of the brine was 6.17 , the tonnage 
of Glauber salt in the lake is about 98,000 short tons. The grade, however, is considerably below the commercial grade of 10 percent. Most other lakes in the mapped area are nonsaline and, of the few that do show white incrustations of soluble salts around their borders, it appears likely that the total quantity of Glauber salt is small.

\section{CLAY}

Clay of commercial grade has been mined in the past from several localities in the area, but by 1949 there had been no active operations for many years. Brick was the only product; clays of the Fort Union formation, alluvial clays, and clays of glacial Lake Souris were used.

According to Clapp and Babcock (1906, p. 189-220), several plants operated in the years 1904 to 1906 . The Kenmare Hard Coal, Brick, and Tile Co. mined clay from an exposure of the Fort Union formation, about 2 miles south of Kenmare in the NE1/4 sec. 32, T. 160 N., R. $88 \mathrm{~W}$. Lignite, which was in contact with the clay, was employed as fuel. At least three other plants - one near Donnybrook, one near Burlington, and the other about 4 miles west of Minot in the $\mathrm{S} 1 / 2$ sec. 18 , T. 155 N., R. 83 W.-had similar operations. A plant about 1 mile southeast of Minot used alluvium for the production of soft-mud bricks. Clapp and Babcock (1906, following p. 189) described some of the physical properties of the clays used.

Clapp and Babcock (1906, p. 202) also described the kinds of brick that could be produced from the clays. According to them, the clays at Kenmare will make a dense pressed brick that ranges in color from light cream to red. The clay that was mined a few miles northeast of Minot, according to Clapp and Babcock $(1906$, p. 219-220), would probably make excellent architectural material for ornamental purposes; with the right amount of sand, it could possibly be used for drain and sewer pipe. When baked it was light reddish cream in color and very firm. The clay northeast of Minot, which overlies lignite, is reported to be 8-12 feet thick; it is gray and has a smooth greasy feel. Its composition was determined by Clapp and Babcock (1906, p. 220) :

\begin{tabular}{|c|c|}
\hline Silica & $\begin{array}{l}\text { Percent } \\
56.86\end{array}$ \\
\hline lumina & 25.03 \\
\hline on oxide & 6. 11 \\
\hline Lime & .71 \\
\hline Magnesia _. & .76 \\
\hline tash & .50 \\
\hline------1 & \\
\hline
\end{tabular}

Brick from the Burlington plant was believed to be fairly well suited for common drain tile.
It is not clear why all these plants went out of operation; it is therefore difficult to evaluate the extent to which the clays will be used in the future. From past operations, it appears that the clays of the Fort Union formation were the most suitable for most uses. There are large reserves of these clays in the area, but, except in a few places along the valleys of the Souris and Des Lacs Rivers, they are nearly all buried under thick deposits of glacial drift.

\section{RELATION OF GEOLOGY TO AGRICULTURAL DEVELOPMENT}

There is a direct relation between the surface geology and agricultural development in the area. Some characteristics of the geologic units favor agricultural development; others are detrimental. Several of these characteristics have a direct bearing on the irrigability of the area, chief among which are the poor surface drainage and the low permeability of the ground-moraine plain. The ground-moraine plain has almost no integrated surface drainage, and all the runoff drains into the nearest undrained depression. Moreover, the till is nearly impermeable. The Bureau of Reclamation conducted extensive permeability tests and other land-classification studies; as a result of which, in 1950 and 1951, it indicated that most of the ground-moraine plain in the Souris River area, if not all, was probably unsuited for irrigation. On the other hand, the glacial Lake Souris deposits have considerab'y better surface drainage than the ground-moraine plain; because they consist almost entirely of sand or silt, they are moderately to highly permeable.

The very characteristics of the ground-moraine plain that tend to make it unsuited for irrigation favor dry farming. The poor surface drainage prevents rapid runoff, and the nearly impermeable till tends to hold the moisture in the upper part of the soil zone. Moreover, the till of the ground moraine is sufficiently fine and contains such a variety of rock fragments of diverse composition that its upper surface decomposes rather quickly into a fertile agricultural soil. As a result, the use of commercial fertilizers is nearly unknown in the area.

Although similar in composition to the ground moraine, the Max moraine and the other end moraines have so much local relief, in most places, that agricultural development is limited to the smaller level tracts. The remainder of the land is well suited to stock raising, because of the plentiful water in the undrained depressions and the good pasturage adjacent to undrained depressions.

Dry farming has been carried on in the silty parts of the glacial Lake Souris deposits, but the moderate permeability of the deposits has allcwed precipitation 
to drain too rapidly through the soil. The far more permeable sandy parts of the deposits are poorly adapted to dry farming, except during years of above-average precipitation. Moreover, wind erosion has produced dunes and "blowouts" in the sandy areas. Many sandy parts of the deposits are therefore used only for stock raising.

Stratified deposits, such as ice-marginal outwashchannel deposits, terrace deposits, eskers, kames, and similar deposits are generally not as well suited to farming as is the ground-moraine plain. Because they consist largely of sand and gravel, soil is slow to form from the parent material and is usually too thin for agricultural development. Also, permeability is generally high and precipitation drains rapidly to levels beneath the soil zone. Kames and eskers form an uneven surface but are generally farmed across if they are not too numerous on the ground-moraine plain. The alluvium in the valleys of the Souris and Des Lacs Rivers is farmed intensively, except where it is covered with trees and brush. It retains moisture adequately and has a desirable nearly flat surface.

\section{RELATION OF GEOLOGY TO CONSTRUCTION PROBLEMS}

Some deposits in the area are suitable for construction material. Some deposits provide firm building foundations, but others do not. Each mapped deposit has different physical and chemical characteristics that affect construction. Under the heading "Engineering geology", engineering properties for each geologic unit have been discussed. These properties are summarized here as they affect different types of construction. Statements regarding the engineering properties of the various map units are based in part on laboratory tests of representative samples, and in part on field observations of the behavior of these units under various conditions of construction. Therefore, the following statements will be of use to those engaged in construc. tion, but they cannot take the place of detailed tests necessary for the design of specific engineering structures.

\section{HIGHWAY CONSTRUCTION}

Road building is the foremost type of local construction. Several federal and state highways traverse the area, and secondary roads bound nearly every section. All sand and gravel used in bituminous mix for paved roads and for road metal is obtained locally. The various stratified deposits of glacial origin contain large reserves of sand and gravel for these purposes.

Till is the most widespread material in the area. It is commonly used in construction of subgrades, a purpose for which it is ideally suited. Fills constructed of till form a fairly stable roadbed, as the material com- pacts well and is sufficiently impervious to minimize frost heaving. Road cuts excavated in till have fairly stable slopes, inasmuch as till tends to stand nearly vertical and is slow to gully. However, because of its high plasticity, till is slippery when wet and ruts badly. It can be moved by power shovel, although commonly it is tough and compact. In a few places large boulders may require special handling, and partly cemented caliche zones occur commonly.

The most common road failures occur across kettle holes and other undrained depressions, owing to several factors. Most depressions contain small ponds, or are continuously moist, causing the subgrade of the road to be saturated most of the time. In most places, the material in the undrained depressions consists of a mucky, plastic, organic, silty clay, which, together with the adjacent till, is also used for subgrade. In the subgrade, this silty clay is particularly subject to lateral displacement when wet, excessive shrinkage and settlement when dry, and extensive frost heaving during winter months.

Roads on stratified glacial deposits are generally stable. Most of the material has sufficient range in grain size and angularity to minimize lateral displacement. Compaction strength is high and frost heaving is negligible. Also, cuts excavated in this material generally have high slope stability and do not gully excessively.

Several types of problems are encountered when constructing roads in deposits of glacial Lake Souris. Roads built in sandy deposits are subject to (a) excessive wind erosion of the grade, (b) filling of the ditches with blown sand, and (c) lateral displacement of the grade due to low cohesion of the sand grains. Ditches and roadbed also gully excessively, presenting a problem that has been alleviated locally by use of till as a surface binder. Roads built in silty deposits do not have the above problems but are particularly susceptible to frost heaving.

Most of the alluvium along the river valleys makes a fairly stable fill, if well compacted and drained. But because the water table is close to the surface during parts of the year, drainage is a problem. Silty alluvium is subject to frost heaving. All of the alluvium is easily excavated.

Bedrock is uncovered so rarely that it is a minor consideration. Most of the surface bedrock is sufficiently compact that excessive settlement is unlikely. All of the bedrock can be excavated with power equipment, except a few local sandstone beds that require blasting. A few beds of uncemented sand in the Tongue River member is subject to lateral displacement and gullying. Lignite is poor material for subgrades; not 
only does it slack rapidly, but it is usually saturated with water. In the Cannonball member, alternating thinly bedded silty shales and silty sands are subject to frost heaving; slope stability in cuts in these strata varies from low to high, depending upon the material.

Landslide areas should be avoided in highway construction. Inasmuch as most slides are confined to valley walls of rivers and major trbutaries, they can generally be circumvented. Most of the landslides are inactive, but they indicate failures that may recur in the future. Excavation of steep slopes, especially at the toe of a slide, may reactivate the slide; added load on a slide may do likewise. In addition, slide areas are generally poorly drained and therefore contain excessive water.

All streams in the Souris River area are small, and geologic considerations will probably not be important in connection with bridge construction. Owing to the great depth to bedrock, abutments and piers of any bridges built across the Souris and Des Lacs Rivers would probably be constructed in surficial deposits, chiefly alluvium and glacial outwash. The alluvium consists of clay, silt, or sand; it overlies glacial outwash that consists of sand, gravel and some boulders. In some areas the alluvium is swampy and contains, near the surface, several feet of humus-rich muck. The upper part of the Des Lacs River valley, especially, is covered by swamps and shallow lakes. Fills and bridge approaches built across these areas would require special consideration because of lateral displacement and settlement

\section{CONSTRUCTION RELATING TO IRRIGATION}

Proposed plans for irrigating parts of the Souris River area include the construction of large lateral canals, pumping plants, and several small dams. The plan under consideration by the Bureau of Reclamation in 1953 was to bring water from the Garrison dam on the Missouri River across the Coteau du Missouri to irrigate parts of the glacial Lake Souris area (unpublished U.S. Bureau of Reclamation map, 1952). A large canal would be constructed across the Coteau du Missouri from Garrison dam via McClusky, and the Lincoln valley sag (see fig. 2 and pl. 15 for locations) and, thence, north along the west border of the glacial Lake Souris to the International Boundary. From the International Boundary, the canal would continue eastward to the east border of the glacial Lake Souris, southward to a point about eight miles northeast of Karlsruhe, and thence eastward toward Devils Lake. One small dam known as the Westhope dam has been proposed to impound the Souris River about 1 mile south of the International Boundary east of Westhope. Two pumping plants have been proposed, one at the Westhope dam site and one known as the Gardena
Pumping Plant, about 10 miles east of Upham and about 3 miles north of Willow Creek.

Construction of large canals may involve problems concerning geology. According to Herman Dupree of the U.S. Bureau of Reclamation (oral communication), some cuts for the large canal across the Cotean du Missouri will be 40 feet deep or more, and several kinds of material of various degrees of slope stability, permeability, and ease of excavation will be exposed or removed. Much of the excavation in the Max moraine will probably be in till. In this material cut slopes are probably stable at fairly steep angles, gullying should be minor, and the till should be sufficiently impermeable to prevent serious leakage. However, part of the course of the proposed canal might coincide with the preglacial course of the Knife River (see pl. 14). If so, sand and gravel might have to be excavated. Because of the greater permeability of these deposits, leakage may be serious. Also, bank stability would probably be lower than in till, especially in the sand. In most places on the Coteau du Missouri, bedrock, although deeper than any cuts that would be expected, is the Tongue River member of the Fort Union formation. Characteristics of these strata are described in the section on descriptive geology. Lignite beds intersected in this member would cause special problems. They are the strongest aquifers in the bedrock and generally carry water under pressure. Many wells southeast of Minot, near the escarpment of the Coteau du Missouri, have artesian flow. Water loss from canals dug into lignite beds, therefore, would probably be negligible, but loss of water into the canal might affect nearby water wells adversely.

Canals dug near the west and east margins of the glacial Lake Souris area would be cut mostly in ground moraine that is similar in physical characteristics to the Max moraine, except that the ground-moraine surface is flatter and has far fewer undrained depressions. Special problems might arise where canals cross large ice-marginal outwash channels that are as much as 1 mile wide and are commonly floored with $10-15$ feet of permeable sand and gravel. Unless precautions are taken, leakage is likely; but use of the nearly impervious till to line permeable sections of the canal is suggested. East of the lake area outwash channels of any size are rare, and little leakage is likely in canal construction.

\section{BUILDING CONSTRUCTION}

The Souris River area is rather thinly populated and cities are small. Unless some unforeseen factor causes a large population increase, few large buildings will be constructed in the foreseeable future. No special geologic considerations are involved in the construction 
of present-day structures. Till, which mantles most of the area, makes a stable foundation material. Minot, the largest city, has only a few buildings more than three stories high and nearly all of these are on a large, highly stable outwash terrace. The deposits of glacial Lake Souris will probably not cause any construction problems for building excavations; the only material that might create problems is a highly plastic and thinly laminated lake clay, which is probably too deeply buried to be penetrated in any building construction. There have been no geologic problems in the construction of buildings on alluvium, though settlement might result from construction in humus-rich swampy areas owing to compaction of organic matter.

\section{REFERENCES CITED}

Akin, P. D., 1947, Geology and ground-water conditions at Minot, N. Dak.: North Dakota Geol. Survey Ground-Water Studies 6, $99 \mathrm{p}$.

Alden, W. C., 1905, The drumlins of sontheastern Wisconsin : U. S. Geol. Survey Bull. 273, p. 9-43.

1932, Physiography and glacial geology of eastern Montana and adjacent areas: U. S. Geol. Survey Prof. Paper $174,133 \mathrm{p}$.

Anderson, S. B., 1952a, Summary of the H. L. Hunt Company Oliver No. 1, Bottinean County, N. Dak.: North Dakota Geol. Survey Circ. 9, 11 p.

- 1952b, Summary of the Ajax Oil Company Bell No. 1 well : North Dakota Geol. Survey Circ. 10, 13 p.

—_ 1953a, Summary of the Hunt Oil Company Shoemaker No. 1 well, MeHenry County, N. Dak.: North Dakota Geol. Survey Circ. 8, 15 p.

- 1953b, Summary of the Wanate Oil Company, M. O. Lee and Silas Engen No. 1, Ward County, N. Dak.: North Dakota Geol. Survey Circ. 14, 17 p.

Andrews, D. A., 1989, Geology and coal resources of the Minot region, North Dakota: U. S. Geol. Survey Bull. 906-B, p. $43-84$.

Armstrong, J. E., and Tipper, H. W., 1948, Glaciation in northcentral British Columbia: Am. Jour. Sci., v. 246, no. 5, p. $283-310$.

Aronow, Saul, Dennis, P. E., and Akin, P. D., 1953, Geology and ground-water resources of the Minnewakan area, Benson County, North Dakota : North Dakota Geol. Survey GroundWater Studies 19, $125 \mathrm{p}$.

Ballard, W. N., 1942, Regional geology of Dakota Basin: Am. Assoc. Petroleum Geologists Bull., v. 26, p. 1568.

Benson, W. E., 1951, Structure contour map of the Knife River area, N. Dak.: U. S. Geol. Survey Prelim. Map, 1 sheet.

- 1952, Geology of the Knife Rivel area, North Dakota: U. S. Geol. Survey open-file report, 323 p.

Benson, W. E., and Laird, W. M., 1947, The Eocene in North Dakota [abs.] : Geol. Soc. America Bull. 58, p. 1166-1167.

Binyon, E. O., 1951, North Dakota sodium sulphate deposits: U. S. Bur. Mines Rept. Inv. 4880, p. 28.

Branch, J. R., 1947, The geology of the Flora quadrangle: North Dakota Geol. Survey Bull. 22, $35 \mathrm{p}$.

Brant, R. A., 1953, Lignite resources of North Dakota: U. S. Geol. Survey Circ. 226, 78 p.

Bretz, J H., 1943, Keewatin end moraines in Alberta, Canada : Geol. Soc. America Bull.. v. 54, p. 31-52.
Brown, R. W., 1939, Fossil plants from the Colgate member of the Fox Hills sandstone and adjacent strata: U. S. Geol. Survey Prof. Paper 189-I, p. 239-275.

Brown, R. W., and Lemke, R. W., 1948, Newly discovered outcrops of the Cannonball formation in North Dakota: Science, v. 107, p. 624-625.

Carol, Hans, 1947, The formation of roches moutonnées: Jour. Glaciology, v. 1, no. 2, p. 57-59.

Chamberlin, T. C., 1883, Terminal moraine of the second glacial epoch: U. S. Geol. Survey 3d Ann. Rept., p. 378-393.

Christianson, E. A., 1956, Glacial geology of the Moose River, Saskatchewan: Saskatchewan Dept. Mineral Resources Rept. 21, $35 \mathrm{p}$.

Chapman, L. J., and Putman, D. F., 1951, The physiography of southern Ontario: Toronto Univ. Press, $284 \mathrm{p}$.

Clapp, C. H., and Babcock, E. J., 1906, North Dakota clays: North Dakota Geol. Survey 4th Bienn. Rept., p. 98-243.

Collier, A. J., 1918, The Nesson anticline, Williams County, N. Dak. : U. S. Geol. Survey Bull. 691, p. 211-217.

Deane, R. E., 1950, Pleistocene geology of the Lake Simcoe district, Ontario : Canada Geol. Survey Mem. 256, 105 p.

Dyson, J. L., 1952, Ice-ridged moraines and their relations to glaciers: Am. Jour. Sci., v. 250, p. 204-211.

Easker, D. G., 1949, Geology of the Tokio quadrangle: North Dakota Geol. Survey Bull. 24, 35 p.

Easton, G. B., 1950, Thirty-second annual report, Coal Mine Inspection Department. State of North Dakota: $24 \mathrm{p}$.

Flint, R. F., 1947, Glacial geology and the Pleistocene epoch: New York, John Wiley and Sons, $535 \mathrm{p}$.

1949a, Leaching of carbonates in glacial drift and loess as a basis for age correlation: Jour. Geology, v. 57, no. 3, p. 297-303.

1949b, Pleistocene drainage diversions in South Dakota : Geografiska annaler, Årg. 1949, nos. 1-4, p. 56-74.

1955, Pleistocene geology of eastern South Dakota : U. S. Geol. Survey Prof:Paper 262, 173 p.

Fox, S. K., and Ross, R. J., 1942, Foraminiferal evidence for the Midway (Paleocene) age of the Cannonball formation in North Dakota: Jour. Paleontology, v. 16, p. 660-673.

Fraser, F. J., and others, 1935, Geology of southern Saskatchewan: Canada Geol. Survey, Dept. Mines Mem. 176. 137 p.

Gilbert, G. K., 1904, Alaska glaciers and glaciation in Harriman Alaska Expedition, v. 3: New York, Doubleday, Page, and Co., p. 77-78.

Gott, G. B., 1948, Preliminary report on the geology of the Zahl No. 4 quadrangle, North Dakota: U. S. Geol. Survey open-file report, p. 1-10.

Grant, U. S., and Higgins, D. F., 1913, Coastal glaciers of Prince William Sound and Kenai Peninsula: U. S. Geol. Survey Bull. 526, 75 p.

Gravenor, C. P., 1953, The origin of drumlins: Am. Jour. Sci., v. 251, p. 674-681.

Grossman, I. G., 1949, Sodium sulphate deposits of western North Dakota, a progress report: North Dakota Geol. Survey Rept. Inv. 1, 66 p.

Hage, C. O., 1945, Geological reconnaissance along lower Liard River, British Columbia, Yukon, and Northwest Territories: Canada Geol. Survey Paper 45-22, 33 p.

Holmes, C. D., 1941, Till fabric: Geol. Soc. America Bull., v. 52, p. 1299-1354.

- 1947, Kames: Am. Jour. Sci., v. 245, p. 240-249.

Howard, A. D. (in press), Cenozoic history of northeast Montana and northwest North Dakota: U. S. Geol. Survey Prof. Paper 326. 
Howard, A. D., Gott, G. Ba., and Lindvall, R. M., 1946, Late Wisconsin terminal moraine in northwestern North Dakota [abs.]: Geol. Soc. America Bull., v. 57, no. 12, pt. 2, p. 1204-1205.

Jensen, F. S., 1951, Disconformity at the contact of the Fox Hills sandstone and Hell Creek formation in northeastern Montana [abs.]: Geol. Soc. America Bull., v. 62, no. 12, pt. 2, p. 1453 .

Johnston, W. A., 1946, Glacial Lake Agassiz, with special reference to the mode of deformation of the beaches: Canada Geol. Survey Bull. 7, 20 p.

Kelley, C. C., and Farstad, L., 1946, Soil Survey of the Prince George area, British Columbia: British Columbia Soil Survey Rept. 2, 58 p.

Kline, V. H., 1942, Stratigraphy of North Dakota: Am. Assoc. Petroleum Kelowna, B. C. Geologists Bull, r. 26, p. 336-379.

Laird, W. M., 1941, Selected deep-well records: North Dakota Geol. Survey Bull. 12, p. 4-6.

1946, The subsurface stratigraphy of the Nesson anticline: North Dakota Geol. Survey Bull. 21, p. 11-25.

1951, Well data and tops of significant wells: North Dakota Geol. Survey mimeographed paper, $12 \mathrm{p}$.

1952a, Well data and tops of significant wells: North Dakota Geol. Surrey Circ. 5, 2d rerision, p. 1-36.

1952b, Data on Price No. 1 well: North Dakota Geol. Survey Circ. 6, $31 \mathrm{p}$.

1952c, Williston basin in North Dakota: Address given to the Alberta Society of Petroleum Geologists, Calgary, Alberta, $25 \mathrm{p}$.

Laird, W. M., and Towse, D. F., 1951, Stratigraphy of North Dakota with reference to oil possibilities: North Dakota Geol. Survey Rept. Inv. 2, sheet 1; revised, 1953.

Lavine, Irvin, and Feinstein, Herman, 1936, Natural deposits of sodium sulfate in Forth Dakota: Am. Inst. Min. Metall. Engineers Contr. 97, 8 p.

Lemke, R. W.. 1953, Geology of the Velva quadrangle, North Dakota: U. S. Geol. Survey Geol. Quad. Map GQ 31.

1954, Revised interpretation for the origin of linear glacial ridges in north-central North Dakota [abs.] : Geol. Soc. America Bull., v. 65, no. 12, pt. 2, p. 1380.

Lemke, R. W., Jensen, F. S., and Smith, J. H., 1951, Linear crevasse fillings, outwash channels, and other similarly oriented glacial features in north-central North Dakota [abs.] : Geol. Soc. America Bull., v. 62, no. 12, pt. 2, p. 1460.

Lemke, R. W., and Kaye, C. A., 1953, Geology of the Bowbells quadrangle, North Dakota: U. S. Geol. Survey Geol. Quad. Map GQ 26.

Leonard, A. G., 1904, Geological formations of North Dakota: North Dakota Geol. Surrey 3d Bienn. Rept., p. 140-177.

Leonard, A. G., and Eaton, H. N., 1925, Description of the lignite deposits of North Dakota, Divide and Burke Counties: North Dakota Geol. Survey Bull. 4, p. 78-80 and 146-153.

Leonard, A. G. (and others), 1908, Fifth biennial report State Geological Surrey of North Dakota: Bismarck, 278 p.

Leonard, A. G., Babcock, E. J., and Dove, L. P., 1925, The lignite deposits of North Dakota: North Dakota Geol. Survey Bull. $4,240 \mathrm{p}$.

Leverett, Frank, 1932, Quaternary geology of Minnesota and parts of adjacent states: U. S. Geol. Survey Prof. Paper $161,149 \mathrm{p}$.

Lindvall, R. M., and Hansen, W. R., 1947, Preliminary report on the geology of the Kermit No. 3 quadrangle, North Dakota: U. S. Geol. Survey open-file report, 9 p.
Lindvall, R. M., and Hansen, W. R., 1948, Preliminary report on the geology of the Zahl No. 3 quadrangle, North Dakota: U. S. Geol. Survey open-file report, $12 \mathrm{p}$.

Mc.Gehee, J. R., 1952. A résumé of the Flk Point formation in view of recent drilling in the Williston basin: Billings Geol. Soc. Guidebook 3d Ann. Field Conf., p. 64.

Nevin, C. MI., 1946, The Keene dome, Northeast McKenzie County, N. I)ak. : North Dakota Geol. Survey Bull. 21, p. 1-10.

Nordquist, J. W., 1955, Pre-Rierdon Jurassic stratigraphy in northern Montana and Williston basin: Billings Geol. Soc. Guidebook Sixth Field Conf., p. 96-106.

Parks, B. C., 1951, Petrography of American lignites: Econ. Geology, v. 46, no. 1, p. 23-50.

Ray, L. R., 1935, Some minor features of valley glaciers and valley glaciation: Jour. Geology, v. 43, no. 4, p. 297-322.

Sharp, R. P., 1953, Glacial features of Cook County, Minn.: Am. Jour. Sci., v. 251, no. 12, p. 855-883.

Simpson, H. E., 1929, Geology and ground-water resources of North Dakota: U. S. Geol. Survey Water-Supply Paper $598,312 \mathrm{p}$.

Sloss, L. L., and Laird, W. M., 1946, Devonian stratigraphy of central and northwestern Montana: U. S. Geol. Survey Oil and Gas Inv. Chart 25.

Smith, H. T. U., 1948, Giant glacial grooves in northwest Canada: Am. Jour. Sci., v. 246, no. 8, p. 503-514.

Tetrick, P. R., 1949, Glacial geology of the Oberon quadrangle: North Dakota Geol. Survey Bull. 23, 35 p.

Townsend, R. C., 1950, Deformation of the Fort Union formation near Lignite, N. Dak. : Am. Assoc. Petroleum Geologists Bull., v. 34, no. 7, p. 1552-1564.

- 1951. Preliminary geology of Rival No. 2 (Columbus) quadrangle: U. S. Geol. Surrey open-file map.

1954a, Geology of the Noonan quadrangle, North Dakota

U. S. Geol. Survey Geol. Quad. Map GQ 44.

1954b, Geology of the Crosby quadrangle, North Dakota :

U. S. Geol. Survey Geol. Quad. Map GQ 46.

-.._ 1954c, Geology of the Portal quadrangle, North Dakota: U. S. Geol. Survey Geol. Quad. Map GQ 47.

Townsend, R. C., and Jenke, A. L., 1951, The problem of the origin of the Max moraine of North Dakota and Canada: Am. Jour. Sci., v. 249, p. 842-858.

Towse, D. F., 1952, Summary of the California Company Thompson No. 1 well, Bottineau County, N. Dak.: North Dakota Geol. Survey Circ. 7, 23 p.

U. S. Bureau of Mines, 1951, Minerals Yearbook.

U. S. Department of Agriculture, 1941, Climate and Man, 1941 Yearbook of Agriculture: U. S. Congress, 77th, 1st Sess., House Doc. 27.

U. S. Geographic Board, 1933, Sixth report: p. 238.

Upham, Warren, 1896, The glacial Lake Agassiz: U. S. Geol. Survey Mon. 25, 658 p.

Wentworth, C. K., 1922, A scale of grade and class terms for clastic sediments: Jour. Geology, v. 30, p. 377-392.

Wickenden, R. T. D., 1945, Mesozoic stratigraphy of the eastern plains, Manitoba and Saskatchewan: Canada Geol. Survey Mem. 239, $87 \mathrm{p}$.

Wilder, F. A., and Wood, R. H., 1902, Lignite deposits of McLean County and preliminary report on Ward County: North Dakota Geol. Survey 2d Bienn. Rept., p. 9-262.

Witkind, I. J., 1959, Geology of the Smoke Creek-Medicine Lake-Grenora area, Montana and North Dakota: C. S. Geol. Survey Bull. 1073. 



\section{INDEX}

A

$\begin{array}{lr}\text { Pagstract } & \text { Page } \\ 1-3\end{array}$

Acknowledgments Aerial photographs_- 4 ; pls. $4,7,8,11,12,13$ Age, Pleistocene deposits in area Agricultural development of area, relation to geology

Ajax Bell well 1, correlations

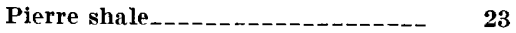

Alluvium, bedding and sorting 103 engineering geology grain size, shape, and lithologic composition._- 103

induration, cementation, and weathering name, location, and areal extent_- 101 origin and type of deposit_._._- 103 stratigraphic position and age thickness_._-_._-___._._._. 101-102 topography

101

Altamont moraine, relation to $\mathrm{Max}$ moraine -

Analyses, chemical, clay, Minot areachemical, lignite, Black Diamond mine soluble salts moraine -....

Mankato till pre-Mankato till terrace deposit_..........

grain size by lithologic composition, terrace deposit

grain-size frequency, ground

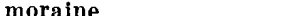

grain size of heavy minerals, Cannonball member.-...-

Tongue River member

pebble count by lithologic composition, glacial till

outwash-channel deposits

terrace deposits

physical properties, Cannonball member..............

terrace deposits

Tongue River member

Anderson, S. B., stratigraphic interpretations cited____ 21, 22

Antelope valley diversion channel_... 69 , 114,115 ; pl. 15

Anticline, gas-bearing, Deering area_-- 126 oil-bearing, Nesson_______-_- 105 Antler Creek.

Arcuate pattern. Max moraine

Arcuate ridges and depressions, Velva area__.____ p. 45-46, $62 ;$ pl. 7 Arcuate washboard moraines_ 111,112 ; pl. 15 Auger holes Aylmer diversion channel_ 69, 114, 115 ; pl. 15

\section{B}

Bedrock depth, relation to drainage history

Bedrock plateau, glacial advance on under Max moraine_-- 106-107 Bedrock surface, contour map_-_-_-_ pl. 2 Benton shale, subsurface Black Butte._._._._._. 78

Boissevain formation of Canada, Turtle Mountains \begin{tabular}{lr} 
Bottineau County, gas field structure & Page \\
\hline & 107
\end{tabular} lignite beds

oil discovery Boulder concentrations, Max moraineBoulder pavements, in tills Bowbells, municipal water well, $\log$-.Bowes member, of Nordquist__._-_._-_ Bridge construction problems Brown, R. W., flora Building construction, foundation problems

Building stone, Velva area________ 35,128 Buried soils, criterion for glacial drift differentiation.

\section{C}

Caliche, Max moraine tions

tions
Canal construction, relation to geology

Cannonball and Ludlow members undifferentiated, Fort Union formation _._._- $11,20,33-34$ member of Fort Union formation, bedding and sorting--

engineering geology

exposures, Sawyer-Verendrye area ${ }_{-} 28-29$ fossils......

grain size, shape, and lithologic composition 29-30

heavy-mineral size analysis

induration, cementation, and weathering -

inferred structure marine facies._._._._._._._. 31 measured section, Verendrye area $\quad 26$ name and location

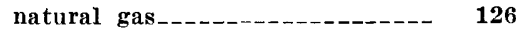

origin and type of deposit_._._._ 31 physical properties, Velva area_-- 32 special localities._-_- 31-32 stratigraphic position _._._._._. 29 stratigraphic sections_________ 26, 31 thickness _._-_-_-_-_-_-_-_-_- 29

Cannonball sea, connections of _..-_- 31 Carbon-14 determinations, lack in area_._._-

Carlile shale, subsurface

Carpenter Lake, sodium sulfate content

Charles formation, subsurface

Cheyenne River, preglacial drainage

Christner, H. R., stratigraphic interpretation

Clay, brick production from___-_-_ 129 chemical analysis, Minot area_-_- 129

Climate --_-_-

Cobban, W. A., core interpretation 11-13, 20 fossils identified__._. Colgate nember of Fox Hills sandstone, Anamoose $_{--} 24,25,26,27$; pl. 3

Glendive area, eastern Montana_- 26

Collapse bedding_-_______- 57, pl. $6 \mathrm{~A}$ Color differences, in glacial drift distinction.........--..-

Concretions, Cannonball member Fox Hills sandstone_________- 26, 28 Tongue River member 34,35
Page Construction materials_-_---- 126-129; pl. 1 Construction problems of area, relation to geology 130 See also Engineering geology.

Coteau du Missouri, coal-bearing Tongue River beds__.__- 32,33 deglaciation of Souris River lobe_ 113-114 escarpment relation to $\mathrm{Max}$ moraine _-_____- 6,42 : pl. 15 Max moraine on physiographic subsection

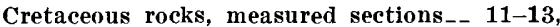

Culture_-_-_-_-_-_-_-_-_-_-_-_-_ 5

Cushman, J. A., foraminifera_.....- 30 D

Dakota sandstone, subsurface_-_-_-_ 13 Deering area, gas-bearing anticline $-{ }_{--} 126$ Descriptive geology________-_ 9-104 Des Lacs River, channels of deglaciation cross section.-. 101 drainage history _._______ 109-111 Iowan or Tazewell till landslides_________- 96-97; pl. 11 lignite exposures in walls _.... 117 $119,120,121$

present drainage--_-

relation to International Boundary - $\quad 7,8$

Des Lacs River valley, adjacent ground-moraine plain_-- 7-8

Des Lacs Western Blum well 1 , correlation with other wells_ $20-22$

stratigraphic interpretations___-_ $\quad 19$

stratigraphic section_-_-_-_-_ 20 Devonian rocks, subsurface

Dewey Price Co., operation in area Dewey Price J. H. Kline well, correlation with other well.-- 19-22, 23-24 $\log \mathrm{s}_{-} \ldots \ldots \ldots-11-19$ Discharge outlets for melt waters Diversion-channel deposits, bedding and sorting

engineering geology grain size, shape, and lithologic composition...-..---

induration, cementation, and weathering - - - - - -----

name, location, and areal extent origin, type of deposit, and history stratigraphic position and age _- 67-68 thickness.-- 67 topography - 67 Diversion channels in deglaciation $-1,113-$ gradient__.___._. 67 Dogden Butte springs from Drainage, melt waters in deglaciation- 114-

pre-Pleistocene and Pleistocene 108-111 Drainage integration, criterion for glacial drift differentiation_ $\quad 39$ Drifts, criteria for differentiation of_ $38-40$, Mankato___-_ 111 ; pl. 15 differentiation in North Dakota_.- 38 
